\title{
Nitrogéntartalmú ösztron származékok előállítása és tumorellenes hatásának in vitro vizsgálata
}

\author{
Doktori (Ph. D.) értekezés
}

\author{
Dr. Huber Judit
}

Témavezetők:

Prof. Dr. Wölfling János

tanszékvezető egyetemi tanár

Dr. Mernyák Erzsébet

tudományos munkatárs

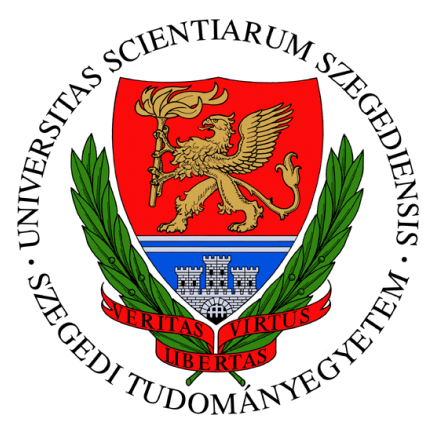

Kémia Doktori Iskola

Szegedi Tudományegyetem

Szerves Kémiai Tanszék

Szeged, 2015 


\section{TARTALOMJEGYZÉK}

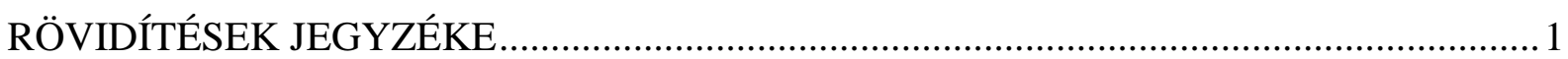

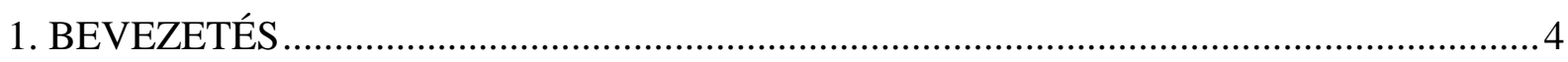

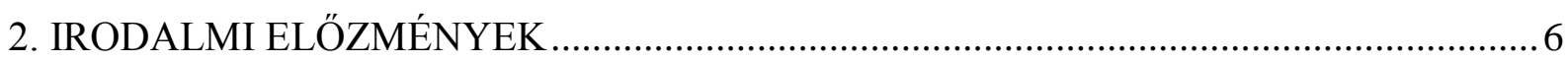

2.1. Az ösztron, valamint természetes és mesterséges származékainak biológiai

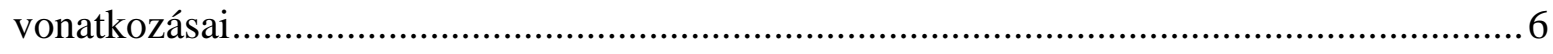

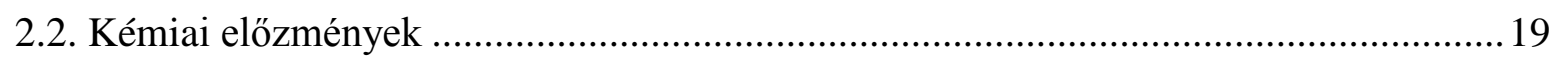

2.2.1. Az 1,3-dipoláris cikloaddíciók ........................................................................... 19

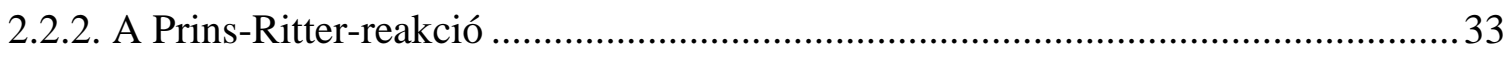

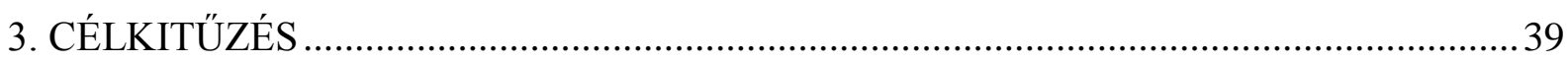

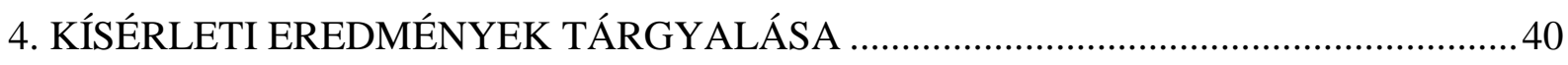

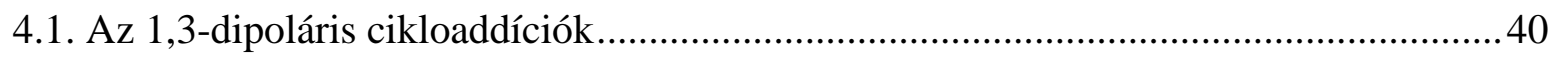

4.1.1. Nitronképzés Lewis-savakkal vagy elektrofil reagensekkel, és a nitronok 1,3dipoláris cikloaddíciói.

4.1.2. A $13 \alpha$ - illetve a $13 \beta$-ösztron sorbeli elektrofil-indukált nitronképzés, és az azt követő 1,3-dipoláris cikloaddíciók................................................................... 43

4.1.3. Az ösztron-azid dipólusok előállítása és CuAAC reakcióik ...................................55

4.2. A $\delta$-alkenil-D-szekoösztronok Lewis-sav-indukált „one pot” Prins-Ritter reakciói ..... 65

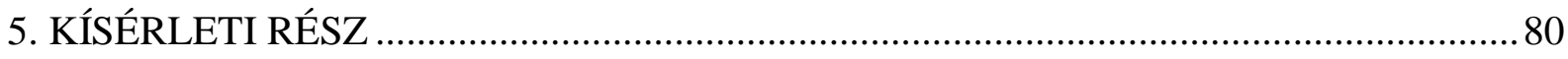

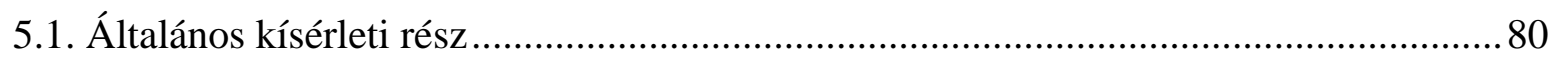

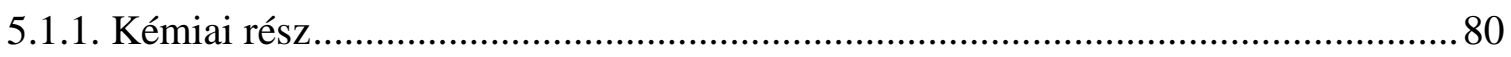

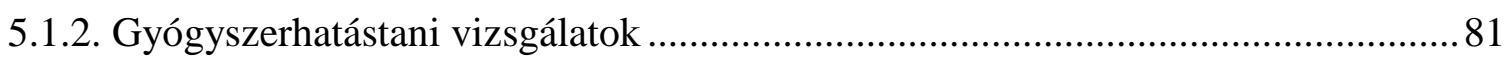

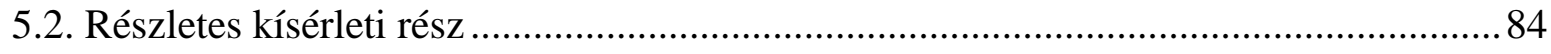

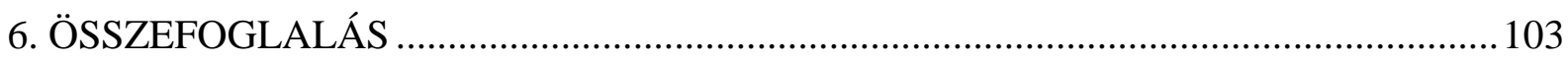

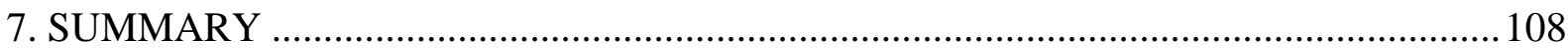

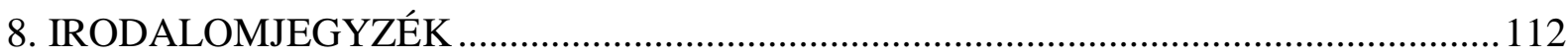

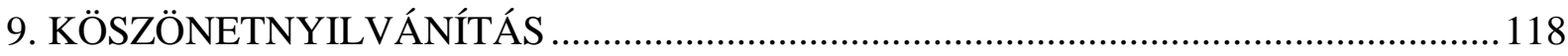

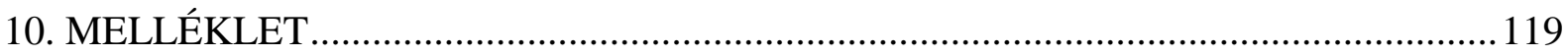




\section{RÖVIDÍTÉSEK JEGYZÉKE}

\begin{tabular}{|c|c|}
\hline AAM & antibiotikum-antimikotikum keveréke \\
\hline $\mathrm{AcOH}$ & ecetsav \\
\hline A2780 & humán petefészek karcinóma \\
\hline A431 & humán bőrlaphám karcinóma \\
\hline $\mathrm{Bi}(\mathrm{OTf})_{3}$ & bizmut(III)-triflát \\
\hline BrdU & 5-bróm-2'-dezoxiuridin \\
\hline COSY & $\begin{array}{l}\text { Correlated Spectroscopy, kétdimenziós korrelációs NMR } \\
\text { spektroszkópiai technika }\end{array}$ \\
\hline $\mathrm{CuAAC}$ & réz-katalizált azid-alkin „click-reakció” \\
\hline DIPEA & diizopropil-etilamin \\
\hline DMSO & dimetil-szulfoxid \\
\hline EGTA & etilén-glikol-tetraecetsav \\
\hline EMEM & Eagle’s Minimum Essential Mediumban, sejt táptalaj \\
\hline $\mathrm{Et}_{3} \mathrm{~N}$ & trietil-amin \\
\hline EtOAc & etil-acetát \\
\hline FBS & borjúszérum \\
\hline G1 & a sejtciklus kezdő fázisa, posztmitotikus, vagy preszintetikus szakasz \\
\hline G1-S & $\begin{array}{l}\text { sejtosztódási ciklus ellenőrző pontja, amely felelős a sejt G1 fázisból a } \\
\text { szintézis fázisba történő eljutásáért }\end{array}$ \\
\hline G2-M & $\begin{array}{l}\text { sejtosztódási ciklus ellenőrző pontja, felelős azért, hogy a sejt a G2 } \\
\text { fázisból a mitózis fázisba jusson }\end{array}$ \\
\hline GTP & guanozin-trifoszfát \\
\hline Hela & méhnyak karcinóma sejtvonal \\
\hline HER-2 & humán epidermális növekedési faktor receptor \\
\hline HFF & humán fibroblaszt sejtvonal \\
\hline HMBC & $\begin{array}{l}\text { Heteronuclear Multiple Bond Correlation, olyan kétdimenziós NMR } \\
\text { spektroszkópiai technika, amely két nem közvetlenül kötésben lévő } \\
\text { különböző magok közötti kölcsönhatást mutatja }\end{array}$ \\
\hline HOPI-festés & hoechst és propídium-jodid festés \\
\hline
\end{tabular}


HSQC

I (+/-)

$\mathrm{IC}_{50}$

Ishikawa

M

M (+/-)

MALDI TOF

MCF-7

MDA-MB-231

MDA-MB-361

MMFF94

MRC-5

MTT-módszer

NBS

NFM

NIS

NMM

1D/2D NMR

NOE

NOESY

PBS

PCR

$\mathrm{PhSeBr}$

PMA

$\mathrm{PPh}_{3}$

RPMI

S

SEM

$\mathrm{S}_{\mathrm{N}} 2$
Heteronuclear Single Quantum Coherence, olyan kétdimenziós NMR spektroszkópiai technika, amely két közvetlenül kötésben különböző magok közötti kölcsönhatást mutatja pozitív vagy negatív induktív effektus maximális hatásos koncentráció fele endometriózis sejtciklus mitózis fázisa pozitív vagy negatív mezomer effektus deszorpciós/ionizációs tömegspektrometria ösztrogén receptor pozitív emlőkarcinóma háromszorosan negatív emlőkarcinóma sejtvonal ösztrogén és HER-2 receptort kifejező emlőkarcinóma sejtvonal Merck Molecular Force Field humán intakt tüdő fibroblaszt sejtvonal 3-(4,5-dimetiltiazol-2-il)-2,5-difeniltetrazolium bromid $N$-brómszukcinimid

$N$-fenilmaleimid

$N$-jódszukcinimid

$N$-metilmaleimid

egy- vagy kétdimenziós mágneses magrezonancia

Nuclear Overhauser Effect

Nuclear Overhauser Effect Spectroscopy, olyan kétdimenziós NMR

spektroszkópiai technika, amely a magok téren keresztüli hatásán alapul foszfátpuffer

polimeráz-láncreakció

fenilszelenilbromid

foszformolibdénsav

trifenil-foszfán

Roswell Park Memorial Institute Medium, táptalaj

a sejtciklus szintézis fázisa

standard error of the mean (szórás)

bimolekuláris nukleofil szubsztitúció 
a sejtciklus G1 fázisának egy speciális „része”, ahol a sejtek nyugvó fázisban vannak, bizonyos kémiai jelek hatására azonban ismét visszakerülhetnek a sejtciklusba emlőkarcinóma sejtvonal, amely ösztrogén és progeszteron receptorokat fejez ki HER-2 overexpresszió, ösztrogén-függő sejtosztódás jellemzi

$\mathrm{TsCl}$ tozil-klorid

$\mathrm{V}_{\max }$ maximális sebesség 


\section{BEVEZETÉS}

A szteroidok a természetes szénvegyületek jelentős csoportját alkotják, amelyek a növényi, állati és emberi szervezetben egyaránt elöfordulnak.

A szteroidok az 1. ábrán látható általános szerkezeti képlettel jellemezhetők. ${ }^{1}$ Az ábra a gyürük jelölését, és a szénatomok számozását is bemutatja.

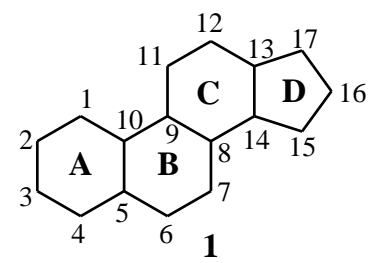

1. ábra: Szterán váz

A szteroidok sokrétű biológiai szerepet látnak el. Az egyik legjelentősebb csoport a szteroid alkoholok, amelyek karbonsavakkal képzett észtereik formájában fordulnak elő a növényi (fitoszterinek), állati és emberi (zooszterinek) szervezetekben, valamint a gombákban (mikoszterinek). A zooszterinek legfontosabb képviselője a koleszterin, amely az állatok és az emberek szövetének mintegy 0,05-5,00\%-át adja. A fitoszterinek közül a sztigmaszterin és a szitoszterin a legismertebb, amelyek a növényi olajokból nyerhetők ki. A mikoszterinek legjobban tanulmányozott és kiemelkedő fontosságú tagja az ergoszterin, amely az anyarozsból és más gombáktól izolálható. Jelentőségét az adja, hogy ultraibolya fénnyel besugározva D-vitamin hatású anyaggá alakul. A szteroidok másik nagy csoportját az epesavak alkotják, amelyek az epében glikollal és taurinnal képzett peptidszerü vegyületek, nátriumsó formában. Az úgynevezett ekdiszteroidok pedig az ízeltlábúak metamorfózisáért felelős hormonok.

Számos biológiailag aktív szteránvázas vegyület tartalmaz oxigén- és nitrogéntartalmú heterociklust. Ilyenek például a szívre ható, vagy kardiotóniás glikozidok, amelyek közös jellemzője a szteránvázhoz 17ß-helyzetben kapcsolódó laktongyürü. A növényi glikozidok egyik különleges csoportjában is fellelhető a heterociklusos váz. Ezek az úgynevezett szaponinok, amelyek vizes oldata erősen habzik, és a vörös vértesteket képes feloldani. Glikozid jellegüknek megfelelően egy aglikon részből és a hozzá kapcsolódó oligoszacharidból épülnek fel. A szteroid szapogeninek közös szerkezeti sajátságát a D- 


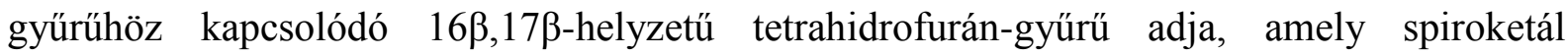
szerkezetet alkot egy tetrahidropirán-gyürüvel. Ezen vegyületcsalád egyes származékaiból néhány szteroid félszintetikus előállítása valósítható meg. A heterociklusos szerkezeti elem a mellékvesekéreg-hormonok csoportjában is megtalálható. Az egyik leghatékonyabb mineralokortikoszteroid, az aldoszteron 13-as helyzetü formilcsoportja a 11ß-helyzetü hidroxilcsoporttal ciklofélacetált képez. A nitrogéntartalmú szteránvázas vegyületek jelentős hányadát a szteroid alkaloidok teszik ki, nevezetesen a szolanidin, a tomatidin és a batrachotoxin.

A nemi hormonok a nemi funkciókat közvetlenül irányító hormonok. A hím nemi hormonok az androgének, amelyek a másodlagos nemi jelleg kialakulását segítik elő, továbbá anabolikus hatásuk révén fokozzák a fehérjebeépülést az izomzatba. A női nemi hormonok a petefészekben, a placentában illetve kisebb mértékben a mellékvesében képződnek. Ide tartoznak az ösztrogének és a gesztagének.

A természetes eredetű szteroidok kémiai módosításával olyan szintetikus származékok nyerhetők, amelyek hordozzák az eredeti biológiai hatást, de amellett új, hasznos aktivitást is mutatnak. Célzott kémiai változtatásokkal továbbá elérhető az elsődleges funkció elvesztése, és amennyiben egyéb hatás kerül elötérbe, így szelektíven ható szteroidok fejleszthetők.

Doktori kutatómunkámban a természetes ösztron olyan irányú módosításait valósítottuk meg, amelyek hormonálisan inaktív, de antitumor jellegü vegyületekhez vezettek. Kettős célunkat elsősorban a D-gyürü átalakításával valósítottuk meg: megnöveltük a tagszámát és/vagy nitrogéntartalmú heterociklust építettünk rá. Az újszerü származékok szintézise és szerkezetvizsgálata szerves kémiai értelemben is jelentős kihívást jelentett. 


\section{IRODALMI ELŐZMÉNYEK}

\subsection{Az ösztron, valamint természetes és mesterséges származékainak biológiai vonatkozásai}

Az élő szervezetben az ösztrogének a nemi jelleg meghatározásáért, a progeszteron (gesztagén) pedig az endometriális ciklusért és a terhesség fenntartásáért felelős. $\mathrm{Az}$ emberben és az állatvilág jelentős részében egyaránt három ösztrogén hatású vegyület fordul

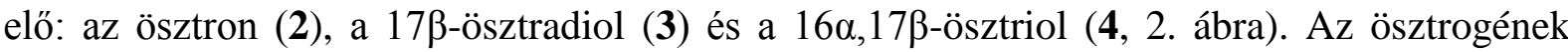
közös szerkezeti eleme az aromás A-gyürü és a transz-gyürüanellációk. A B-gyürü általában félszék, míg a C-gyürü szék konformációjú. A molekulában lévő oxigénatomok egymástól meghatározott távolságban helyezkednek el, amely fontos szerepet tölt be az ösztron és az ösztradiol hormonhatásának kifejtésében. A természetes ösztrogének elősegítik a sejtek osztódását (proliferációját), ${ }^{2}$ felelősek a másodlagos nemi jelleg kialakulásáért, fenntartják a lipidegyensúlyt és a só-vízháztartást, valamint hozzájárulnak a transzportfehérjék és a véralvadási faktorok szintéziséhez.
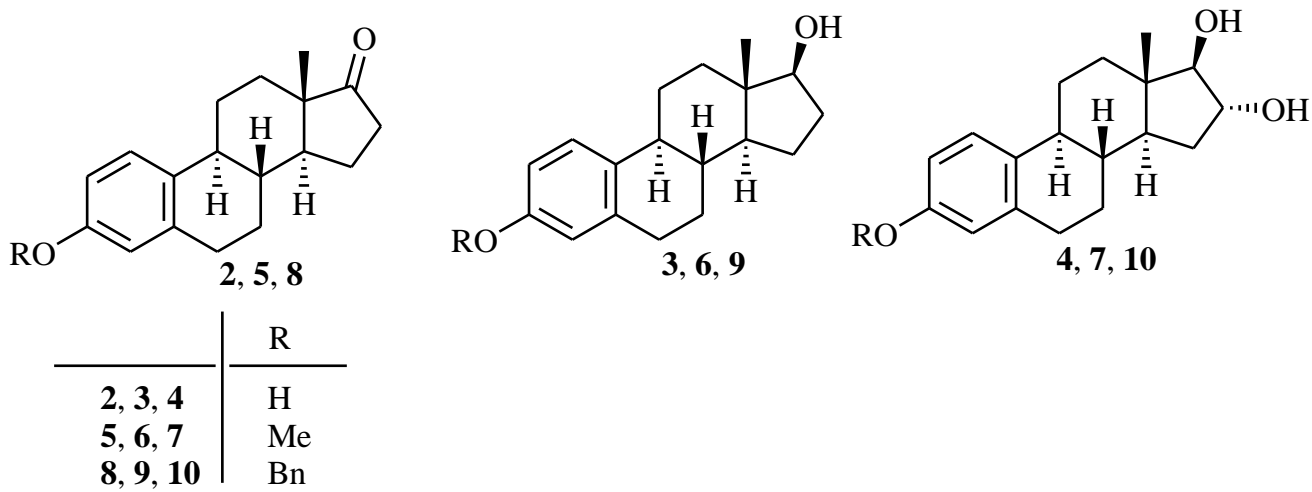

2. ábra: Az ösztrogének (2-4) és 3-as helyzetben védett származékaik (5-10)

Az irodalomban számos szintetikus ösztránvázas vegyület ismeretes, szerteágazó biológiai hatással, ide tartoznak többek között az antitumor hatású származékok is. ${ }^{3} \mathrm{Az}$ ösztron (2) szerkezetének célzott kémiai változtatásával hormonálisan inaktív, ugyanakkor tumorellenes vegyületek nyerhetők. Ezek különböző úton fejtik ki a hatásukat. Lehetnek enzim inhibitorok, amelyek a szteroid-bioszintézisben részt vevő egyes enzimek müködését gátolják, akadályozva így a hormonképződést, és ezáltal a hormonfüggő daganatok fejlődését. 
Ismeretesek az antiösztrogének is, amelyek az ösztrogén receptorok aktív centrumából szorítják ki az endogén ligandot, és a visszacsatolási mechanizmusnak köszönhetően visszaszorítják a hormonok bioszintézisét. Számos közlemény számol be továbbá olyan vegyületekről, amelyek nem a hormonális célpontokat támadva fejtik ki antitumor hatásukat. Ezek közül kiemelendőek az antimitotikus vegyületek, amelyek a tubulin fehérje polimerizációját befolyásolják, és olyan rendellenes mikrotubulus-hálózat kialakulását idézik elő, amely nem teszi lehetővé a sejtosztódást. Az antiproliferatív hatóanyagokat két csoportba sorolják: a citosztatikus szerek gátolják a sejtosztódást, míg a citotoxikusak károsítják a sejteket. Az előbbieket a rák korai, az utóbbiakat a későbbi stádiumában szokás alkalmazni.

A fentiek alapján tehát az ösztron-alapú tumorellenes szerek támadáspontjai lehetnek az ösztron bioszintézisében részt vevő enzimek. A szteroidhormonok szintézise a koleszterinből (11) indul, ebből valósul meg a progeszteron $(\mathbf{1 2})$, az androgének $(\mathbf{1 3}, \mathbf{1 4})$ és az ösztrogének $(2,3)$ képződése (3. ábra). ${ }^{4}$ Az ösztron (2) és a 17ß-ösztradiol (3) kialakulását közvetlenül az aromatáz és a 17ß-hidroxiszteroid-dehidrogenáz-1 katalizálja. Az aromatáz végzi a tesztoszteron (14) ösztron származékokká $(\mathbf{2}, 3)$ történő átalakítását. A $17 \beta$ hidroxiszteroid-dehidrogenáz-1 az ösztron (2) keto-funkciójának hidroxilcsoporttá történő módosításáért felel. A szteroidszulfatáz végzi az ösztron-szulfát (15, inaktív forma) ösztronná (2, aktív forma) történő átalakítását. A folyamat reverzibilis, a szulfotranszferáz enzim szulfát-észter kötést alakít ki a fenolos hidroxil-funkción, ezzel inaktiválva az ösztront (2). ${ }^{5}$ Az említett három enzim (aromatáz, 17ß-hidroxiszteroid-dehidrogenáz-1, szteroidszulfatáz) müködésének gátlásával jelentősen befolyásolható a női nemi hormonok szintézise a szervezetben. 


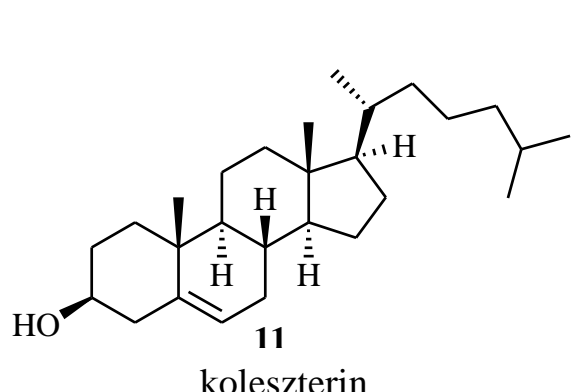

koleszterin

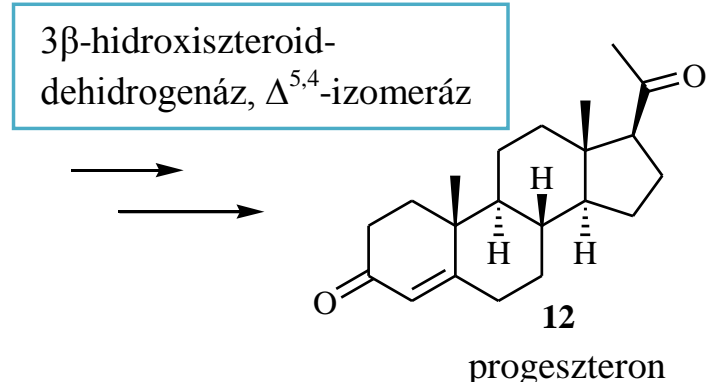

progeszteron

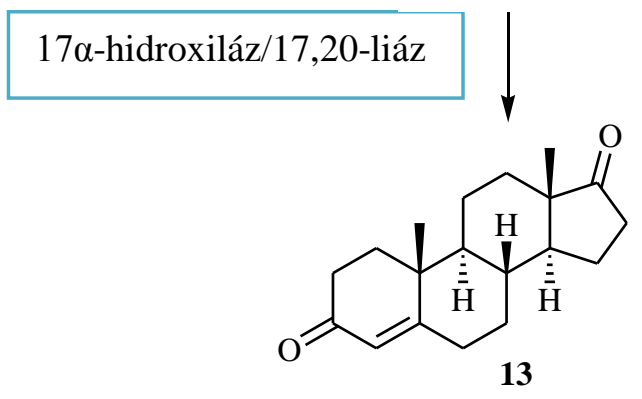

4-androsztén-3,17-dion

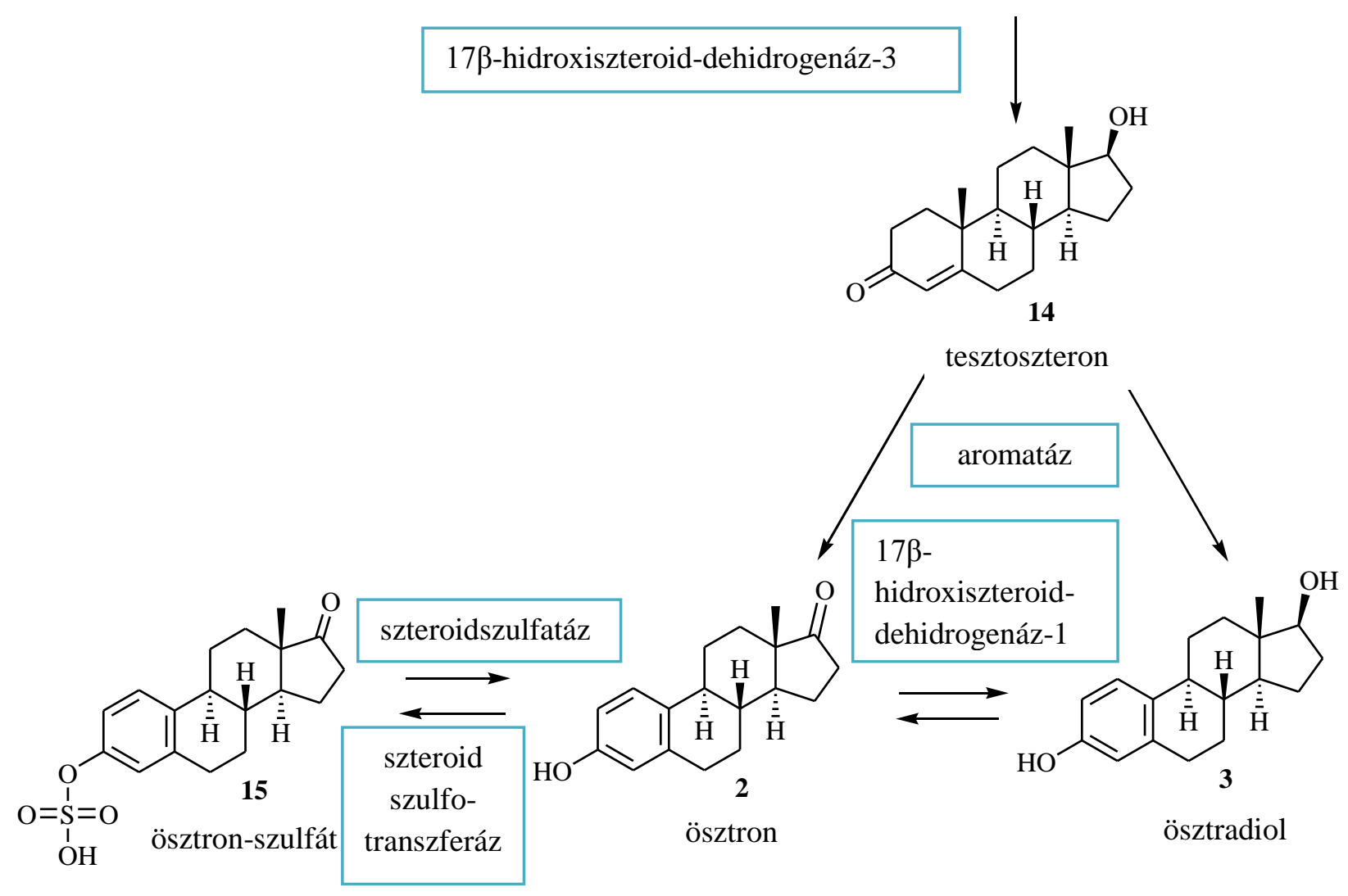

3. ábra: Az ösztron (2) és az ösztradiol (3) bioszintézise 
Az ösztránváz 2-es helyzetébe halogént beépítve olyan aromatáz inhibitorok $(\mathbf{1 6}, \mathbf{1 7})$ nyerhetők, amelyek irreverzibilisen gátolják az enzimet (4. ábra). ${ }^{6}$ Az ösztron (2) egyes szubsztituált származékai (18, 19) a 17ß-hidroxiszteroid-dehidrogenáz-1 inhibitoraiként hatnak. $^{7}$

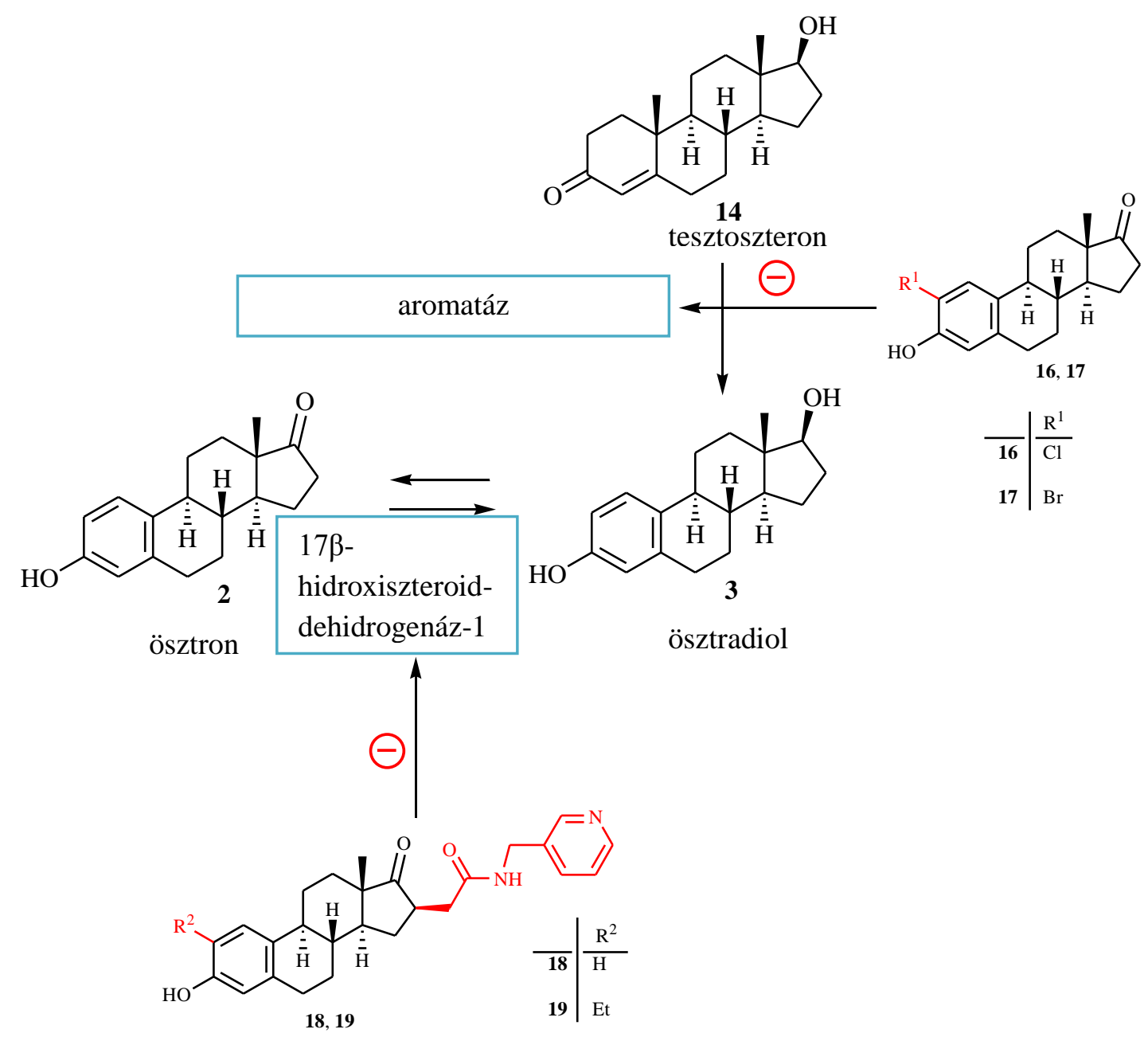

4. ábra: Aromatáz és 17ß-hidroxiszteroid-dehidrogenáz-1 inhibitorok (16-19, pirossal jelöltem a vegyületek azon funkciós csoportjait, amelyek elősegítik az inhibitorhatás kialakulását) 
Egyes szulfamoilcsoportot tartalmazó ösztron származékok (20-24) a szteroidszulfatáz enzim inhibitorai (5. ábra). ${ }^{8-11}$ Az első generációs szteroidszulfatáz inhibitor (20) citosztatikus hatású (mellékhatásként ösztrogén aktivitással). A második generációs hatóanyagok $(\mathbf{2 1}, \mathbf{2 2})$ azonban kettős hatással rendelkeznek (a 2-metoxi-funkció jelenlétének köszönhetően). Ezen vegyületek $(\mathbf{2 1}, \mathbf{2 2})$ a hormonszintézis gátlása mellett a tubulin polimerizációját is megakadályozzák, így a mitotikus osztódást is. Fischer és kutatócsoportja olyan 3-szulfamoil-aza-D-homoszteroidokat $(\mathbf{2 3}, \mathbf{2 4})$ állított elő, amelyek az ösztron-3-Oszulfamátnál (20) 18-szor hatásosabb szulfatáz inhibitornak bizonyultak $\left(\mathrm{IC}_{50}=1 \mathrm{nM}\right) .{ }^{11} \mathrm{Az}$ irreverzibilis gátlás a szulfamoilcsoportnak köszönhető, továbbá a D-gyürüben lévő piperidindion-funkció és az R-oldallánc a hidrofób-kölcsönhatások kialakulásának kedvez, ezzel növelve a vegyületek $(\mathbf{2 3}, \mathbf{2 4})$ enzimre gyakorolt gátló hatását. A hormonális aktivitás a 23-as és a 24-es jelű vegyületek esetében visszaszorul. 


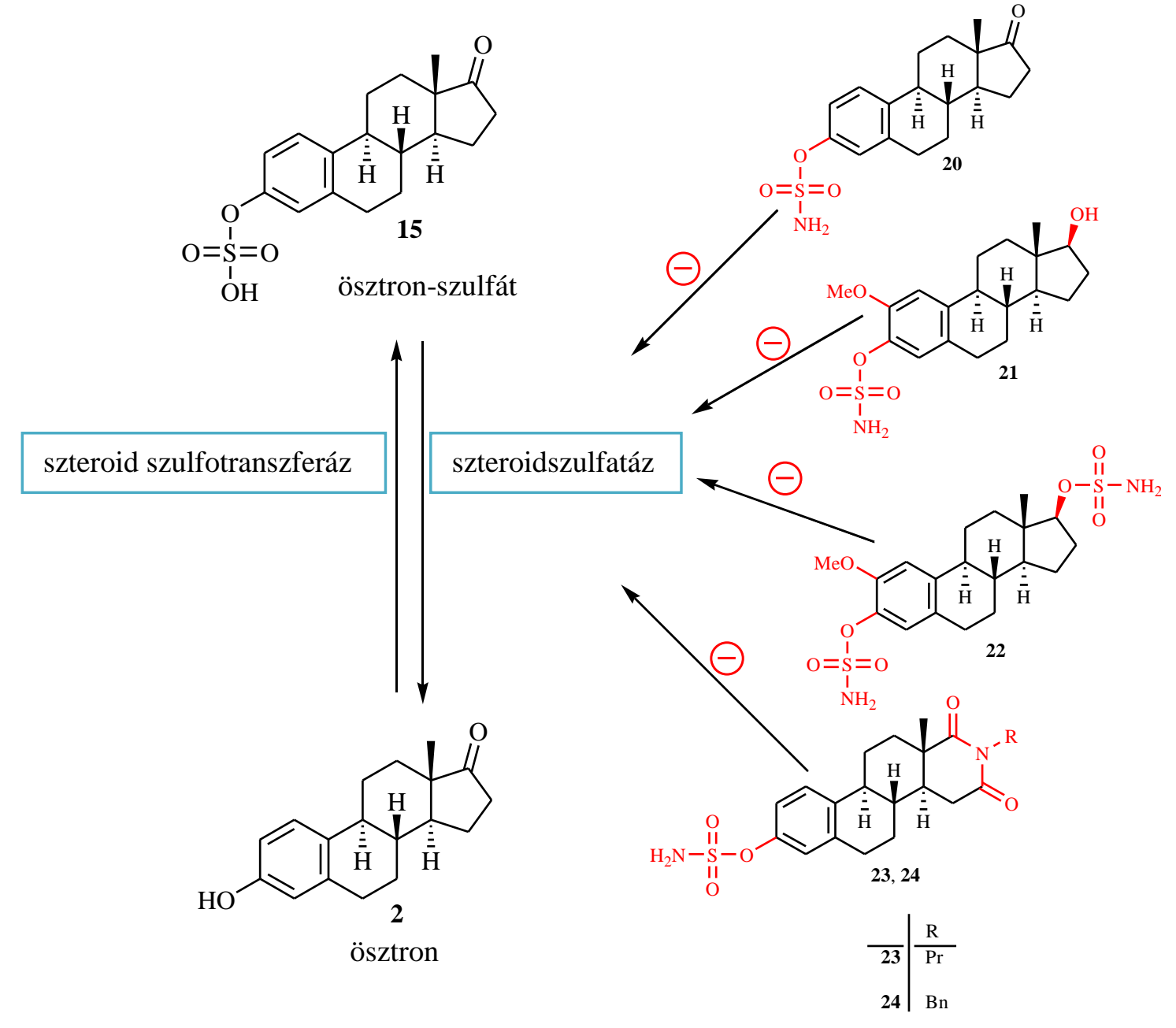

5. ábra: A szteroidszulfatáz enzim inhibitorai (20-24, pirossal jelöltem azon funkciós csoportokat, amelyek elősegítik az inhibitorhatás kialakulását) 
Az ösztron bioszintézisében részt vevő enzimek gátlásán túlmenően antiösztrogének alkalmazásával is kezelhetők a hormonfüggő tumorok. Erre alkalmasak azok az ösztron

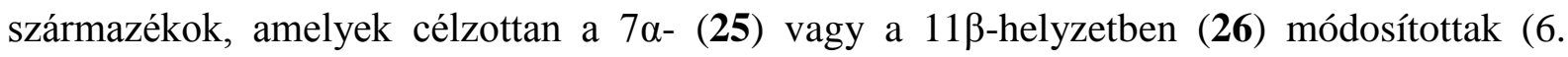
ábra). ${ }^{12,13}$

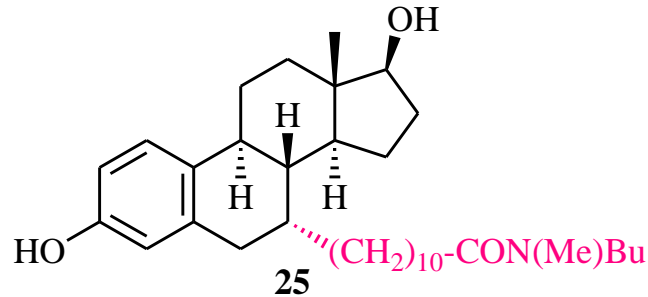

25

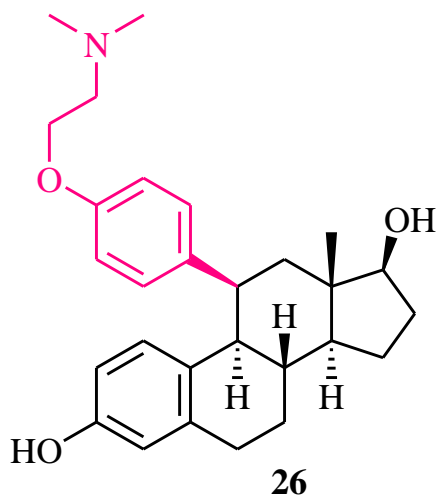

6. ábra: Antiösztrogének $(\mathbf{2 5}, \mathbf{2 6}$, rózsaszínnel jelöltem azon funkciós csoportokat, amelyek elösegítik az antiösztrogén hatás kialakulását)

A fentiekben említettektől eltérő hatásmechanizmussal fejtik ki antitumor aktivitásukat az antimitotikus vegyületek. Ezek vagy a tubulin fehérje polimerizációját akadályozzák meg, vagy éppen ellenkezőleg, felgyorsítják azt. ${ }^{14}$ Így a mitotikus orsó kialakulása zavart szenved, és a sejtosztódási folyamat lehetetlenné válik. A 17ß-ösztradiol (3) 2-es helyzetben történő szubsztituálásával nyert 2-metoxi- (27) vagy 2-etoxi-17ß-ösztradiol (28) a tubulin kolhicinkötőhelyéhez kötődve akadályozza meg a mikrotubulusok képződését, ezáltal a sejtosztódást is (7. ábra). ${ }^{15}$ Hillisch és munkatársai 2011-ben olyan 2-metoxi-D-homoösztron származékot (29) szabadalmaztattak, amelyben a 2-metoxi-szubsztitúción túlmenően a fenolos hidroxilcsoportot szulfamoillá alakították. ${ }^{16}$ Ezen funkciós csoportok beépítésével olyan hatékony antiproliferatív hatású vegyülethez (29) jutottak, amely a tubulin polimerizációjának gátlása útján fejti ki hatását, csökkent ösztrogén aktivitás mellett. 

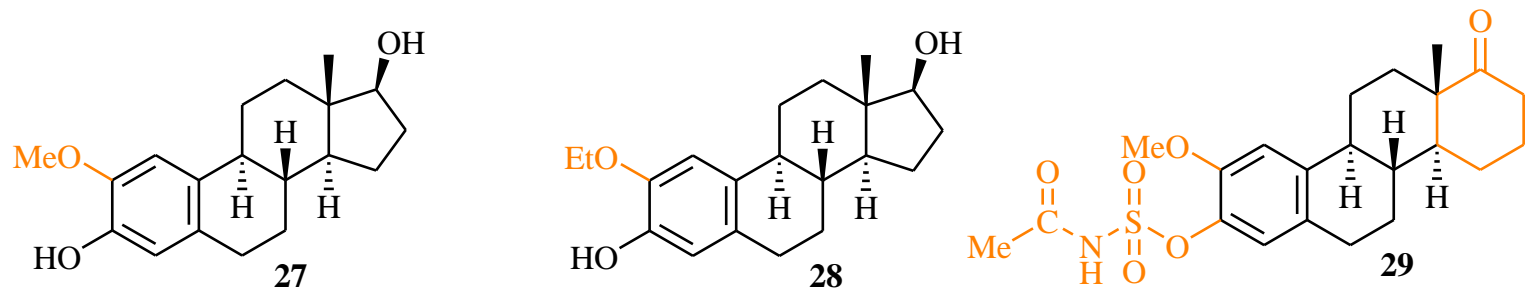

7. ábra: Antimitotikus vegyületek (27-29, narancssárgával jelöltem azon funkciós csoportokat vagy molekularészeket, amelyek elősegítik az antimitotikus hatás kialakulását)

A szteroidok B-gyürüje tagszámának növelésével is előállíthatók antimitotikus hatású vegyületek. Wang és munkatársai 2-es helyzetben szubsztituált B-homo-17ß-ösztradiolokat $(30,31)$ állítottak elő (8. ábra). ${ }^{17}$ Megfigyelték, hogy a ketocsoportot tartalmazó származék (30), a paklitaxelhez hasonlóan, a tubulin polimerizációját fokozza, míg a 2-etoxi-B-homo3,17-diol (31) a tubulin polimerizációját gátolja.
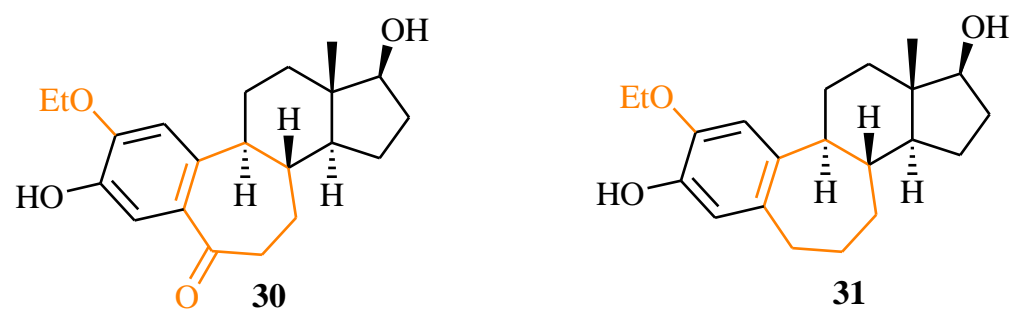

8. ábra: Antimitotikus hatású B-homo-17ß-ösztradiolok (30, 31, narancssárgával jelöltem azon funkciós csoportokat vagy molekularészeket, amelyek elősegítik az antimitotikus hatás kialakulását)

A közelmúltban több olyan közlemény is megjelent, amely nem szteroid jellegű antimitotikus hatású vegyülekről számol be. Ilyen a Tahir és munkatársai által szintetizált, az A-204197 kóddal jelölt vegyület (32), amely oxadiazolin-heterociklust tartalmaz (9. ábra). ${ }^{18}$ Egy naftil-gyürüvel rendelkező oxadiazolin (33) szintén ígéretes, tubulin polimerizációt gátló vegyület. Egy tanulmányban molekuláris dokkolással igazolták, hogy az oxadiazolin-gyürü jelenléte jelentős szerepet játszik a tubulin fehérjével való H-híd kötés kialakulásában ( 9 . ábra). ${ }^{19}$ Mindezek alapján észszerünek tünhet ezen heterociklusoknak egy antitumor hatóanyagba történő beépítése a kívánt antimitotikus aktivitás elérése céljából. 

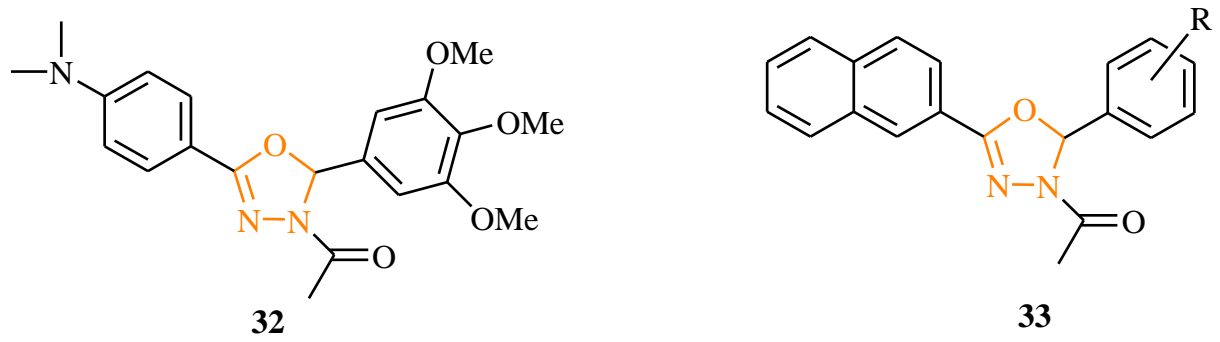

9. ábra: Az antitubulin hatású oxadiazol származékok (32,33, narancssárgával jelöltem azon funkciós molekularészeket, amelyek elősegítik az antimitotikus hatás kialakulását)

A szakirodalomban számos példa található heterociklussal módosított szteroidokra, amelyek antimitotikus aktivitással rendelkeznek. Szerteágazó biológiai hatást tulajdonítanak a szteroid-triazoloknak: antibakteriális, ${ }^{20}$ antimikotikus, ${ }^{21}$ antihisztamin ${ }^{22}$ és HIV-ellenes aktivitást. ${ }^{23}$ A triazol-molekularész nagyfokú hasonlóságot mutat a peptid kötéssel, és H-híd kötés kialakítására képes, azonban a peptidekkel ellentétben kémiailag és metabolikusan is stabil. $^{24}$ Egy indiai kutatócsoport 2010-ben pregnenolon-acetátból kiindulva olyan 20-ketopregnén származékokat állított elő, amelyek oldallánca 1,2,3-triazol-gyürüt tartalmazott. Ezen vegyületek antiproliferatív hatásúnak bizonyultak öt humán tumorsejtvonalon. ${ }^{25}$ Egy másik indiai kutatócsoport kólsavból, illetve dezoxikólsavból képezett triazolokat. ${ }^{26}$ A szteroidok hordozták az alkin-funkciót, az azidocsoportot pedig a nem-szteroid jellegű $\beta$-laktám származékok. A konjugátumok a $\beta$-laktám származékokra jellemző antibakteriális hatásúnak bizonyultak, ugyanakkor antimitotikus aktivitást is mutattak.

Kutatócsoportunk a közelmúltban több közleményben triazolil-szteroidokról számolt be. ${ }^{27-33}$ Többféle szteroid alapvázra, különböző helyzetbe építettek triazol-gyürüt (10. ábra). A célvegyületek antiproliferatív hatását több humán adherens tumorsejtvonalon in vitro tesztelték, MTT-módszer segítségével. Kitünt, hogy egyes vegyületek jelentős sejtosztódást gátló hatást mutatnak. 


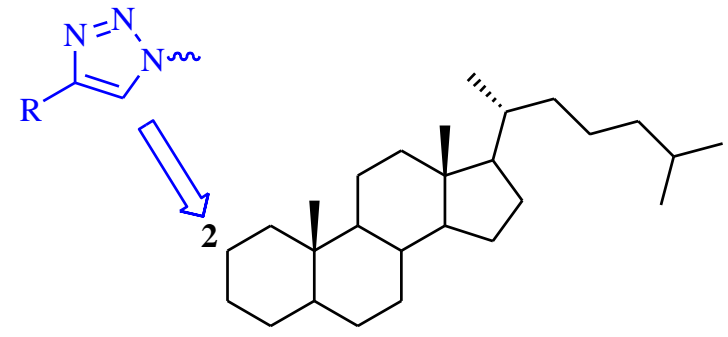

kolesztán váz
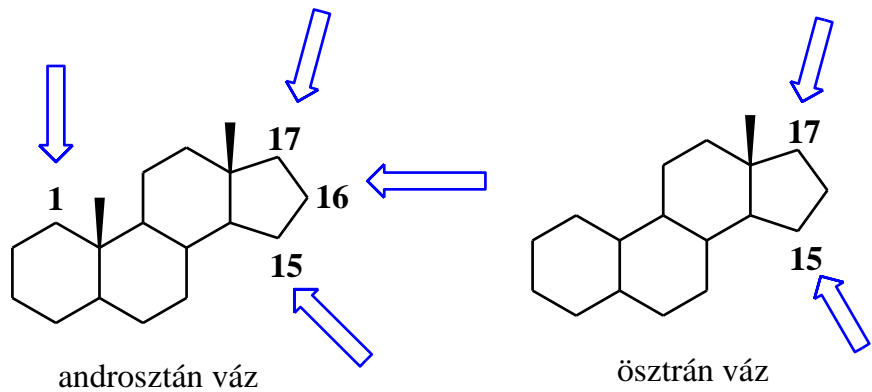

ösztrán váz

10. ábra: Triazolil-gyürü beépítése a különböző alapvázakra (színjelzés: kék)

A rákellenes szteroidok kutatásában a közelmúltban elötérbe került az ösztron olyan irányú szerkezeti módosítása, amely már nem az alapváz szubsztituálására, vagy a homológok előállítására, hanem az egyik gyürüanellációs szénatom (C-13) konfiguráció-változtatására

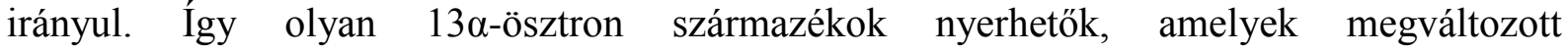
konformációjuk miatt már nem képesek az ösztrogén receptorokhoz való kötődésre, így hormonálisan inaktívak. Amennyiben a 13-epimereknél egyéb biológiai aktivitás mutatkozik, azok szelektív hatású vezérmolekulákká válhatnak. A fentiek miatt a 13a-ösztron származékok irodalma az utóbbi években egyre bővül. Poirier és munkatársai in vitro tesztelték a C-13 és a C-17 konfigurációjában különböző négy diasztereomer 3,17-ösztradiolt $\left(\mathbf{3}, \mathbf{3 4}-\mathbf{3 6}, 11\right.$. ábra). ${ }^{34} \mathrm{~A}$ vegyületek $(\mathbf{3}, \mathbf{3 4}-\mathbf{3 6})$ sejtosztódásra gyakorolt hatását vizsgálták három különböző emlő karcinóma sejtvonalon. Olyan sejtvonalakat választottak, amelyek több szempontból is eltérnek egymástól: az ösztrogén receptor negatív vagy pozitív jellegükben, illetve a sejtek osztódásának ösztrogénfüggésében. Megfigyelték, hogy kis koncentrációban $(0,01-5 \mu \mathrm{M})$ a vegyületek $(\mathbf{3}, \mathbf{3 4}-\mathbf{3 6})$ sejtproliferációt indukálnak az ösztrogén receptor pozitív sejtvonalakon (MCF-7, T-47D). A 13ß-származékoknál (3, 34) ez a hatás fokozottabb volt, mint a 13a-epimereknél (35, 36). Magasabb koncentrációban alkalmazva (> $5 \mu \mathrm{M})$ azonban a vegyületek $(3,34-36)$ mindkét sejtvonalon citotoxikusnak bizonyultak. Ez utóbbi aktivitás az ösztrogén receptor negatív sejtvonalon (BT-20) is megfigyelhető volt minden vegyület $(3,34-36)$ esetében. A vizsgálatok alapján a kutatók azt a következtetést vonták le, hogy a származékok citotoxikus aktivitásukat ösztrogén receptor független mechanizmussal fejtik ki. Az eredményekböl következik továbbá, hogy a 13aepimerek $(\mathbf{3 5}, \mathbf{3 6})$ ösztrogén hatása jelentősen kisebb, mint 13ß-megfelelőiké $(\mathbf{3}, \mathbf{3 4})$. Ez utóbbi megállapítást bizonyították egy további in vitro radioligand-méréssel. Megfigyelték, 
hogy a négy diasztereomer (3, 34-36) közül a 17ß-ösztradiol (3) kötődik leginkább az ösztrogén receptorhoz. A 13ß-származékoknál (3, 34) a 17 $\beta$-hidroxil-funkció inverziója csökkentette a szteroid (34) hormonreceptorhoz való affinitását. Továbbá a flexibilisebb

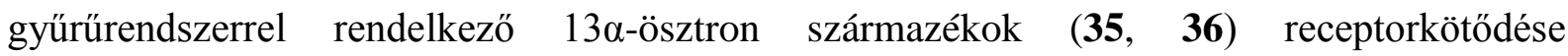
elhanyagolható volt a 13ß-ösztron-sorbeli megfelelöikhez (3, 34) képest. Az in vivo eredmények összhangban állnak az in vitro kísérletekben nyert tapasztalatokkal. A ovarektomizált egerek ösztrogén-érzékeny méhének, illetve hüvelyének tömegnövekedését vizsgálták a diasztereomerek (3, 34-36) beadását követően. Míg a 17ß-ösztradiol (3) szignifikánsan, addig a $13 \alpha$-epimerek $(\mathbf{3 5}, \mathbf{3 6})$ csekély mértékben növelték a méh ill. a petefészek tömegét. Mindezek alapján megállapítható, hogy a természetes, 17 $\beta$-ösztradiol (3) 13-as szénatomjának konfigurációváltozása hormonálisan inaktív 13 $\alpha$-epimereket $(\mathbf{3 5}, \mathbf{3 6})$ eredményez.
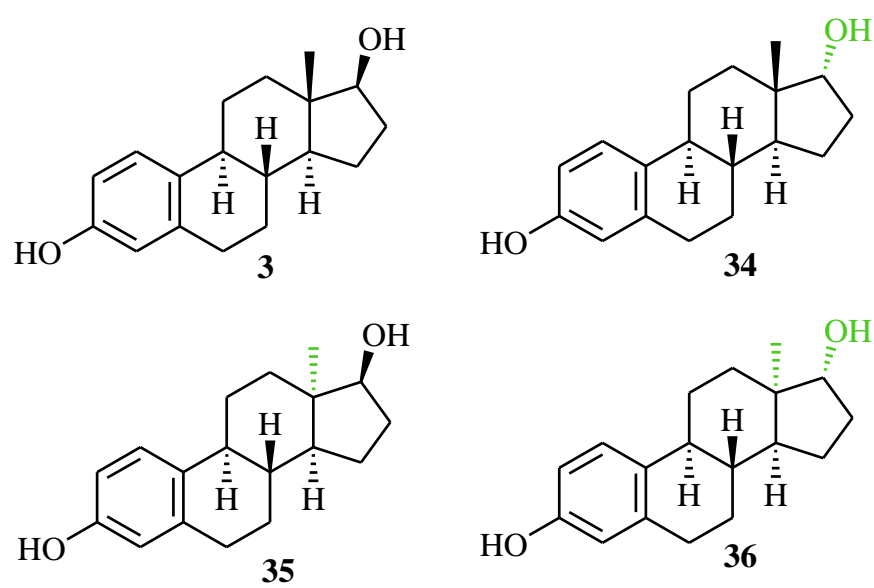

11. ábra: A négy diasztereomer 3,17-ösztradiol $(\mathbf{3}, \mathbf{3 4 - 3 6 )}$ szerkezeti képlete (zöld: a 17ßösztradioltól a C-13 és a C-17 konfigurációjában különböző diasztereomerek) 
Tanszékünk Szteroidkémiai Kutatócsoportja a közelmúltban is számos $13 \alpha$-ösztron származékot állított elö. A D-homoösztron és 3-metil-étere, valamint epimer párjainak (37-40) szintézisét valósították meg, és in vitro sejtosztódást gátló hatásának tesztelését is elvégezték MTT-módszer segítségével, a Szegedi Tudományegyetem Gyógyszerhatástani és Biofarmáciai Intézetével együttmüködve (12. ábra). ${ }^{35-37}$ A teszteket három tumoros (Hela, MCF-7, Ishikawa) és egy intakt sejtvonalon (MRC-5) végezték. A négy (37-40) vegyületből csak a D-homoösztron (37) mutatkozott potensnek, amely vegyület tumorszelektívnek bizonyult a Hela sejtvonalon $\left(\mathrm{IC}_{50}=5,5 \mu \mathrm{M}\right)$, és összemérhető hatásúnak a referenciavegyülettel, a ciszplatinnal $\left(\mathrm{IC}_{50}=6,5 \mu \mathrm{M}\right.$, Hela). Megfigyelték, hogy a fenolos hidroxilcsoport helyett metoxi-funkciót tartalmazó vegyületek $(\mathbf{3 8}, \mathbf{4 0})$ nem mutattak jelentős antiproliferatív hatást. A kísérletek eredményeiből az a következtetés vonható le, hogy Dhomoösztron modellen a 13ß-metilcsoport és a szabad fenolos hidroxil-funkció jelenléte kedvez az antitumor hatás kialakulásának. A 13a-ösztron sorba tartozó homológok $(\mathbf{3 9}, \mathbf{4 0})$ nem befolyásolják a vizsgált tumorsejtek osztódását.
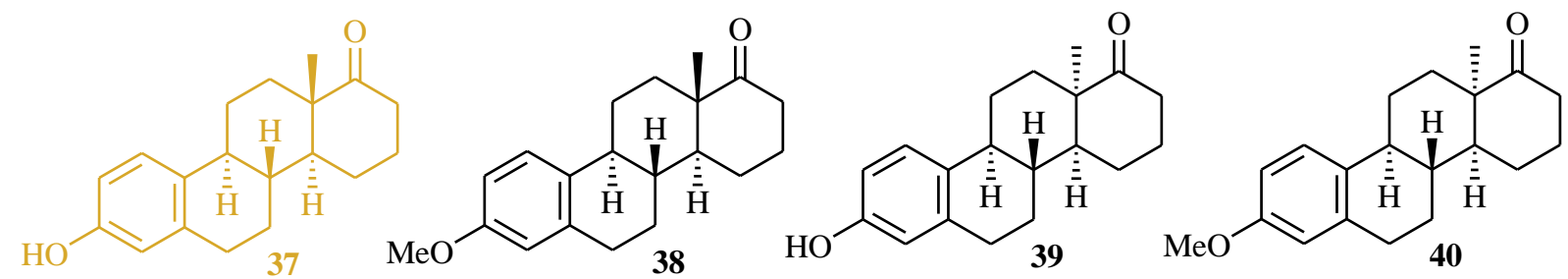

12. ábra: A D-homoösztron származékok (37-40) (barna: a legjobb antiproliferatív hatással rendelkező vegyület)

Annak érdekében, hogy a D-homoösztron (37) hatásmechanizmusát felderítsék, vizsgálták annak ösztrogén, illetve progeszteron receptorhoz való affinitását, radioligandméréssel. ${ }^{35}$ Megfigyelték, hogy a D-homoösztron (37) nem kötődik ezen receptorokhoz. A tesztvegyületet (37) in vivo kísérleti körülmények között is vizsgálták. ${ }^{36}$ A vegyület (37) nem mutatott jelentős uterotrop (a méh tömegének növekedése) hatást. Az eredmények alapján kizárható, hogy a D-homoösztronnak (37) ösztrogén hatású aktív metabolitja képződne a szervezetben. A D-homoösztron (37) hatásmechanizmusát egyéb in vitro módszerekkel is tanulmányozták. ${ }^{38}$ Áramlási citometria segítségével megállapították, hogy a vegyület (37) a sejtciklus G2/M (sejtosztódási ciklus ellenőrző pontja, felelős azért, hogy a sejt a G2 fázisból a mitózis fázisba jusson) fázisátmenetét blokkolja. Továbbá a SubG1 (a G1 fázis egy speciális 
része, ahol a sejtek nyugvó fázisban vannak, bizonyos kémiai jelek hatására azonban ismét visszakerülhetnek a sejtciklusba) fázis jelentős növekedését eredményezi, amely apoptózis jelenlétére utal. PCR (polimeráz-láncreakció) illetve Western-blot technikával igazolták, hogy a D-homoösztron (37) a G2/M fázist szabályozó fehérjék (ciklin B, stathmin) expresszióját megváltoztatta, ezáltal feltehetően felborult a tubulin-mikrotubulus rendszer dinamikája. A HOPI-festés (Hoechst-Propídium-jodid), a kaszpáz-3 és a kaszpáz-9 aktivitás mérésének eredménye is alátámasztotta, hogy a D-homoösztron (37) képes aktiválni az apoptózis mitokondriális útvonalát, így okozza a Hela sejtekben a programozott sejthalált, ugyanekkor 2,5 $\mu \mathrm{M}$ feletti koncentrációk esetén másodlagos nekrózist indukál.

A D-gyürü homologizálását követően a Kutatócsoport figyelme a 13a-ösztrán váz szubsztituálása felé fordult. A cél az volt, hogy hormonálisan inaktív, potenciálisan tumorellenes származékokat nyerjenek. Sikerült olyan 16-oxim-észtert (41) előállítaniuk, amely in vitro jelentős antiproliferatív tulajdonságot mutatott (13. ábra). ${ }^{39}$ Ez volt az első $13 \alpha-$ ösztron származék (41) az irodalomban, amely a ciszplatinnal összemérhető sejtosztódásgátló hatást mutat.

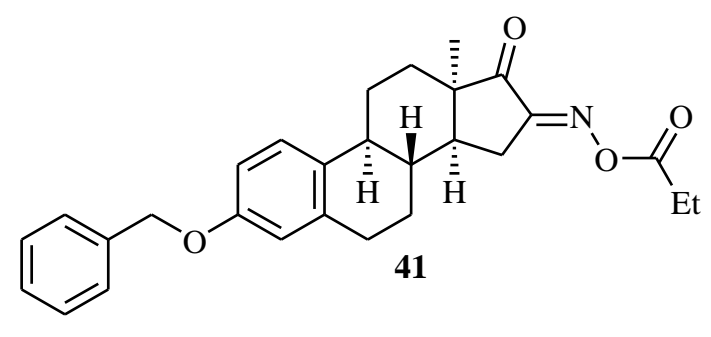

13. ábra: 16-etilkarboniloximino-13 $\alpha$-ösztra-1,3,5(10)-trién-17-on (41)

A vegyület (41) hatásmechanizmusának felderítése érdekében további kísérleteket végeztek. $^{40}$ Sejtciklus analízissel bizonyították, hogy G1-S (sejtosztódási ciklus másik ellenőrző pontja, amely felelős a sejt G1 fázisból a szintézis fázisba történő eljutásáert) átmenetet gátol, továbbá a SubG1 fázist is koncentráció-függően növelte, ami apoptózisra utalt. A HOPI festés és a kaszpáz-3 aktivitás mérés eredményével igazolták az apoptózis jelenlétét. A DNS-szintézis gátlására, és a sejtciklus S-fázisában (a sejtek DNS szintézisének fázisa) lévő sejtpopuláció csökkenésére az úgynevezett BrdU (5-bróm-2'-dezoxiuridin) DNSbe történő beépülésének vizsgálata szolgáltatott további információkat. 


\subsection{Kémiai előzmények}

\subsubsection{Az 1,3-dipoláris cikloaddíciók}

\subsubsection{Az 1,3-dipoláris cikloaddíció általános ismertetése}

Kísérleti munkánk jelentős részét 1,3-dipoláris cikloaddíciós reakciók képezik, amelyekkel hatékonyan állíthatók elő heterociklusos rendszerek. ${ }^{41,42} \mathrm{Az}$ 1,3-dipoláris cikloaddíciók során egy ikerionos oktett szerkezettel rendelkező 1,3-dipólus, és egy többszörös kötést tartalmazó dipolarofil reagál egymással, így egy öttagú gyürü alakul ki (14. ábra). ${ }^{42} \mathrm{Az}$ 1,3-dipoláris cikloaddíciók mechanizmusa a mai napig vitatott. Egyes kutatók azt feltételezik, hogy a mechanizmus koncertikus. ${ }^{43-45}$ Mások szerint azonban egy többlépéses reakció, amely során biradikális intermedierek képződnek. ${ }^{46}$

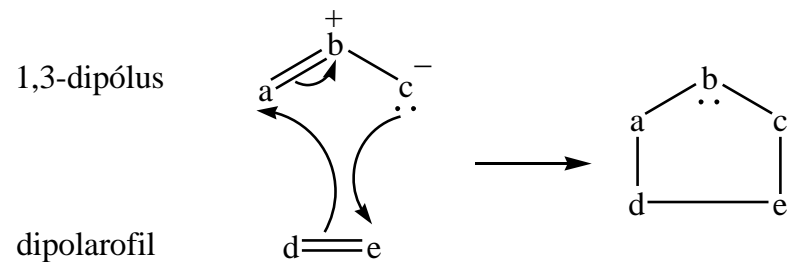

14. ábra: Az 1,3-dipólus és a dipolarofil

Az a jellemző szerkezeti elem, amellyel az 1,3-dipólus rendelkezik, egy allil-anion típusú $\pi$-rendszer, amelyben a $\sigma$-váz három szomszédos atomján négy $\pi$-elektron delokalizálódik. Az allil-anionnal ellentétben, az 1,3-dipólusok tartalmaznak egy „ónium” centrumot $(b)$, amelynek töltése kompenzálja a kétféle oktett struktúrában a két szélső atomon ( $a$ és $c$ ) megoszló negatív töltést (15. ábra). ${ }^{47}$ Így az egész rendszer egy olyan hetero-allilanionnak tekinthető, amely nem hordoz töltést. A terminális atomok nukleofilek és elektrofilek is lehetnek. 


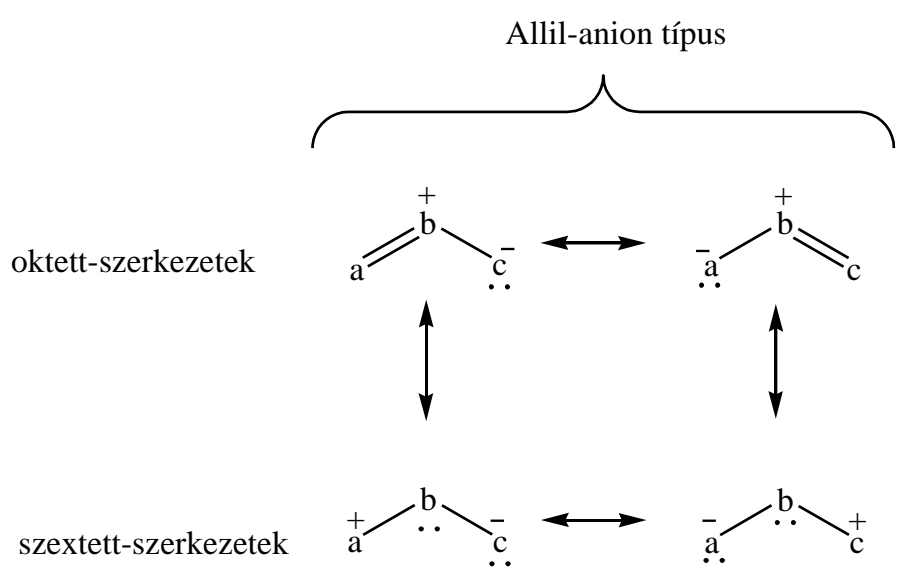

15. ábra: Az allil-anion típusú dipólus mezomer szerkezetei

\subsubsection{Nitron dipólusok előállitása és 1,3-dipoláris cikloaddíciós reakciói}

A nitronok az allil-anion típusú dipólusok közé sorolhatók (16. ábra).

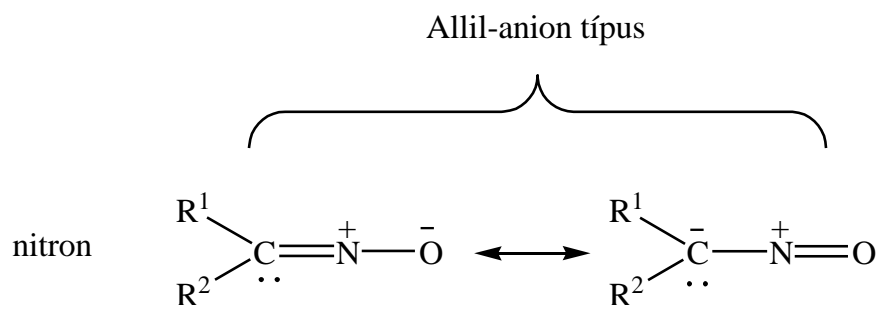

16. ábra: A nitron, mint 1,3-dipólus

A nitronok előállításának egyik irodalomból ismert módszere az oximok és az olefinek elektrofil reagens jelenlétében való nitronképzési reakciója (17. ábra). ${ }^{48} \mathrm{~A}$ folyamat az elektrofil reagens $\mathrm{C}=\mathrm{C}$ kettős kötésre való támadásával indul, majd a gyürüs átmeneti termékre az oxim $N$-, vagy $O$-atomja indítja a nukleofil támadást. Az intermolekuláris reakciók során az oxim sztereokémiája dönti el, hogy melyik atom viselkedik nukleofilként. $Z$-oxim esetén a $N$, míg $E$-oxim esetén ez sztereokémiailag kedvezőtlen, így az $O$ fejti ki a nukleofil támadást. 


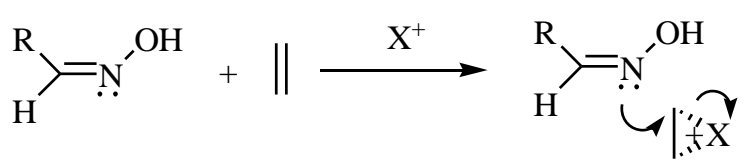

Z-oxim

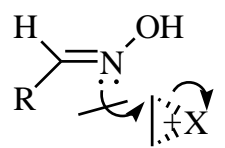

E-oxim

17. ábra: Az oxim és az olefin elektrofil-indukált reakciója

Grigg és munkatársai, valamint Tiecco és kutatócsoportja intramolekuláris gyürüzárást hajtottak végre nyílt láncú alkenil-oximokból kiindulva (18. ábra). ${ }^{48-52}$ A $\gamma$-alkenil-oxim (42) elektrofil reagenssel öttagú gyürüs nitront (44) képezett, melléktermékként pedig hattagú oxazint (46) izoláltak. Ezzel szemben $\delta$-alkenil-oximból (43) kizárólag hattagú gyürüs nitron (45) képződött, a héttagú oxazepin (47), mint melléktermék nem volt izolálható. Tiecco és munkatársai megfigyelték, hogy 17 órás reakcióidő elteltével már kizárólag gyürüs nitronok $(44,45)$ voltak a reakcióelegyben. Az olasz kutatók azt feltételezték, hogy a kiinduási oximokból $(\mathbf{4 2}, \mathbf{4 3})$ képződő 1,2-oxazin és 1,2-oxazepin $(\mathbf{4 6}, \mathbf{4 7})$ egyensúlyi folyamatban átalakult a termodinamikailag stabilabb termékekké $(\mathbf{4 4 , 4 5 )}$.

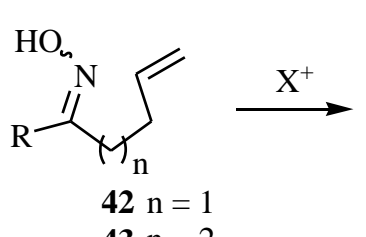

$43 \mathrm{n}=2$<smiles>[X]CC1CCCCC1[Y]</smiles>

$46 \mathrm{n}=1$ $47 \mathrm{n}=2$

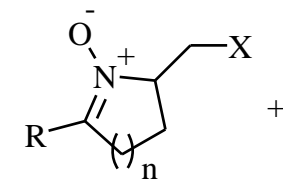

$44 \mathrm{n}=1$

$45 \mathrm{n}=2$<smiles>[X]CC1CCC([R])=NO1</smiles>

$46 \mathrm{n}=1$

$47 \mathrm{n}=2$<smiles>C=CCC=CC=NO</smiles>

$\mathrm{n}=1$

$\mathrm{n}=2$

Z-oxim
$\mathrm{HO}$<smiles>C=CCC=CC=NO</smiles>

$\mathrm{n}=1$

$\mathrm{n}=2$

E-oxim<smiles>[X]CC1C[AlH]C([R])=[N+]1[O-]</smiles>

$44 \mathrm{n}=1$

$45 \mathrm{n}=2$

18. ábra: Nyíltláncú alkenil-oximok $(\mathbf{4 2}, \mathbf{4 3})$ elektrofil-indukált gyürüzárása

Grigg és kutatócsoportja fenilszelenilbromid $(\mathrm{PhSeBr})$ segítségével hajtott végre elektrofil-indukált nitronképzést, azt követően a dipólust $N$-metilmaleimid (NMM, 48) $\mathrm{C}=\mathrm{C}$ dipolarofillel reagáltatták. ${ }^{51}$ Az 1,3-dipoláris cikloaddíció nem bizonyult sztereoszelektívnek. A 19. ábrán látható endo- és exo-cikloadduktumok $(49,50)$ képződtek 3:2 (49:50) arányban. A gyürüzárás során kizárólag $N$-alkilezés történt, $O$-alkilezést nem tapasztaltak. 

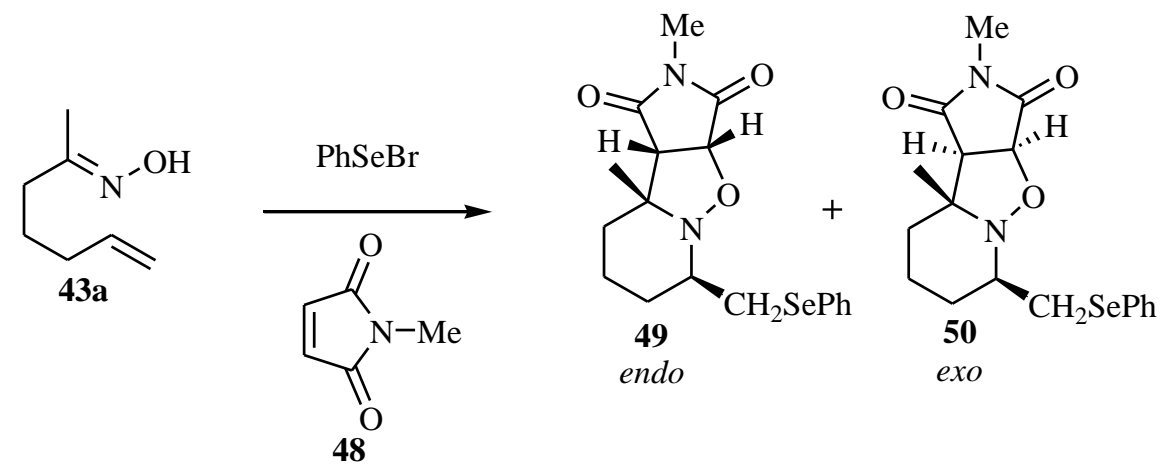

19. ábra: Az 1,3-dipoláris cikloaddíció során képződő endo- és exo-sztereoizomer $(\mathbf{4 9}, \mathbf{5 0})$

Coskun és Parlar, elektrofil-indukált nitronképzést követően, a dipólusokat (51a-g) fenilizocianát (52) $\mathrm{C}=\mathrm{N}$ dipolarofillel reagáltatták (20. ábra). ${ }^{53} \mathrm{~A}$ nitronok $(\mathbf{5 1 a}-\mathbf{g})$ fenilizocianáttal (52) való gyürüzárásában oxadiazolidinon származékokat (53a-g) nyertek. Megvizsgálták a nitronok (51a-g) szubsztituenseinek a reakcióra gyakorolt hatását. Megfigyelték, hogy azon oximok, amelyekben az $\mathrm{R}^{2}=\mathrm{H}(\mathbf{5 1 a})$, vagy az $\mathrm{R}^{1}$ elektronküldő csoportot (51a, c, f) tartalmaz, rövid reakcióidővel, nagy hozammal szolgáltatták az 1,2,4oxadiazolidinonokat (53a, c, f). Az $\mathrm{R}^{1}$ helyzetben elektronvonzó csoportot tartalmazó oximok $(\mathbf{5 1 b}, \mathbf{d}, \mathbf{e}, \mathbf{g})$ esetében a reakcióidő jelentősen nőtt, a hozam ugyanakkor csökkent. Ha a fenilizocianátot (52) 3-szoros feleslegben alkalmazták, és a reakciókat az acetonitril forráspontján végezték, akkor a kívánt cikloadduktumokhoz (53a-g) jutottak. Szobahőmérsékleten, 24 óra alatt sem ment végbe az 1,3-dipoláris cikloaddíció. Ilyen körülmények között az $N, O$-difenilkarbamoil- $N$-benzil-hidroxilamint kapták (56, 20. ábra). A kutatók ebben az esetben azt feltételezték, hogy a 20. ábrán látható 54-es intermedier képződik, amely az 55-ös jelü vegyületen keresztül, újabb fenilizocianáttal (52) történő reakcióban továbbalakul az 56-os vegyületté. 
<smiles>[R]C=[N+]([O-])C[R]</smiles><smiles>O=C=Nc1ccccc1</smiles>

51<smiles>O=C(Nc1ccccc1)O[N+](=Cc1ccccc1)Cc1ccccc1</smiles>
54<smiles>O=CC(O)c1ccccc1</smiles>

$-\mathrm{PhCHO}$

$$
\begin{array}{r|ll}
\mathbf{5 1 , 5 3} & \mathrm{R}^{1} & \mathrm{R}^{2} \\
\hline \mathbf{a} & 3,4-(\mathrm{MeO})_{2} \mathrm{C}_{6} \mathrm{H}_{3} & \mathrm{H} \\
\text { b } & 2-\mathrm{NO}_{2} \mathrm{C}_{6} \mathrm{H}_{4} & \mathrm{H} \\
\text { c } & \mathrm{Ph} & \mathrm{Ph} \\
\text { d } & 2-\mathrm{NO}_{2} \mathrm{C}_{6} \mathrm{H}_{4} & 2,3-(\mathrm{MeO})_{2} \mathrm{C}_{6} \mathrm{H}_{3} \\
\text { e } & 2-\mathrm{NO}_{2} \mathrm{C}_{6} \mathrm{H}_{4} & \mathrm{Ph} \\
\text { f } & 2,3-\left(\mathrm{MeO}_{2} \mathrm{C}_{6} \mathrm{H}_{3}\right. & \mathrm{Ph} \\
\text { g } & 3-\mathrm{NO}_{2} \mathrm{C}_{6} \mathrm{H}_{4} & \mathrm{Ph}
\end{array}
$$<smiles>[R]CN1OC(=O)N(c2ccccc2)C1[R]</smiles><smiles>O=C(Nc1ccccc1)ONCc1ccccc1</smiles><smiles>CC(=O)Nc1ccccc1</smiles><smiles>O=C(Nc1ccccc1)ON(Cc1ccccc1)C(=O)Nc1ccccc1</smiles>

20. ábra: Nitronok (51a-g) fenilizocianát $\mathrm{C}=\mathrm{N}$ dipolarofillel (52) történő 1,3-dipoláris cikloaddíciója

Buchlovic és munkatársai gyürüs nitron dipólust képeztek (57), amelynek 1,3dipoláris cikloaddícióját fenilizocianát dipolarofillel (52) valósították meg (21. ábra). ${ }^{54} \mathrm{Az}$ átalakulás során, 24 óra alatt, $80{ }^{\circ} \mathrm{C}$-on, sztereoszelektíven nyerték az oxadiazolidinon származékot (58), azonban a hozam (60\%) alacsony volt.

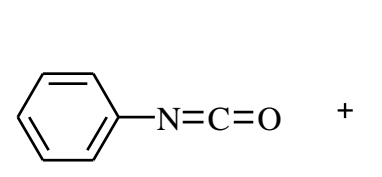

52

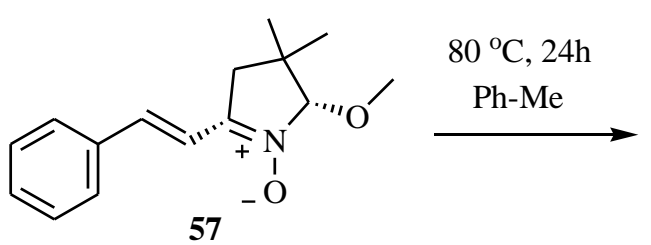

57<smiles>CO[C@@H]1N2OC(=O)N(c3ccccc3)[C@@]2(/C=C/c2ccccc2)CC1(C)C</smiles>

58

21. ábra: A gyürüs nitron dipólus (57) 1,3-dipoláris cikloaddíciója fenilizocianát $\mathrm{C}=\mathrm{N}$ dipolarofillel (58) 
Nitron dipólusok szintézisét és 1,3-dipoláris cikloaddícióit a közelmúltban Tanszékünk Szteroidkémiai Kutatócsoportja szteroid modellen is megvalósította. ${ }^{55,56}$ A Dszekooximok kiindulási aldehidjeinek előállítására hatékony módszert dolgoztak ki a 13ßösztron sorban. ${ }^{57-59}$ Az ösztron 3-as helyzetben védett származékaiból (5, 8) kiindulva a 16-os szénatomon formilezték a vegyületeket $(\mathbf{5}, \mathbf{8})$ etil-formiáttal, nátrium-metilát jelenlétében $(22$. ábra). A formilezést követően hidrides redukcióval cisz- (61c, d és 62c, d) és transz-1,3diolok (61a, b és 62a, b) keverékét kapták. A D-gyürü felnyitásához előbb a primer hidroxilfunkciót jó távozó csoporttá alakították, majd a tozilezett transz-vegyületeket (63a, b és 64a, b) Grob-fragmentációnak vetették alá. Az 1,3-transz-helyzetű alkoholos hidroxil- és a toziloxicsoport térben távol helyezkednek el egymástól, így adottak a feltételek a fragmentációhoz. Lúgos, metanolos forralást követően nyerték a hasznos intermedierként szolgáló D-szekoaldehideket $(\mathbf{6 5}, \mathbf{6 6})$.

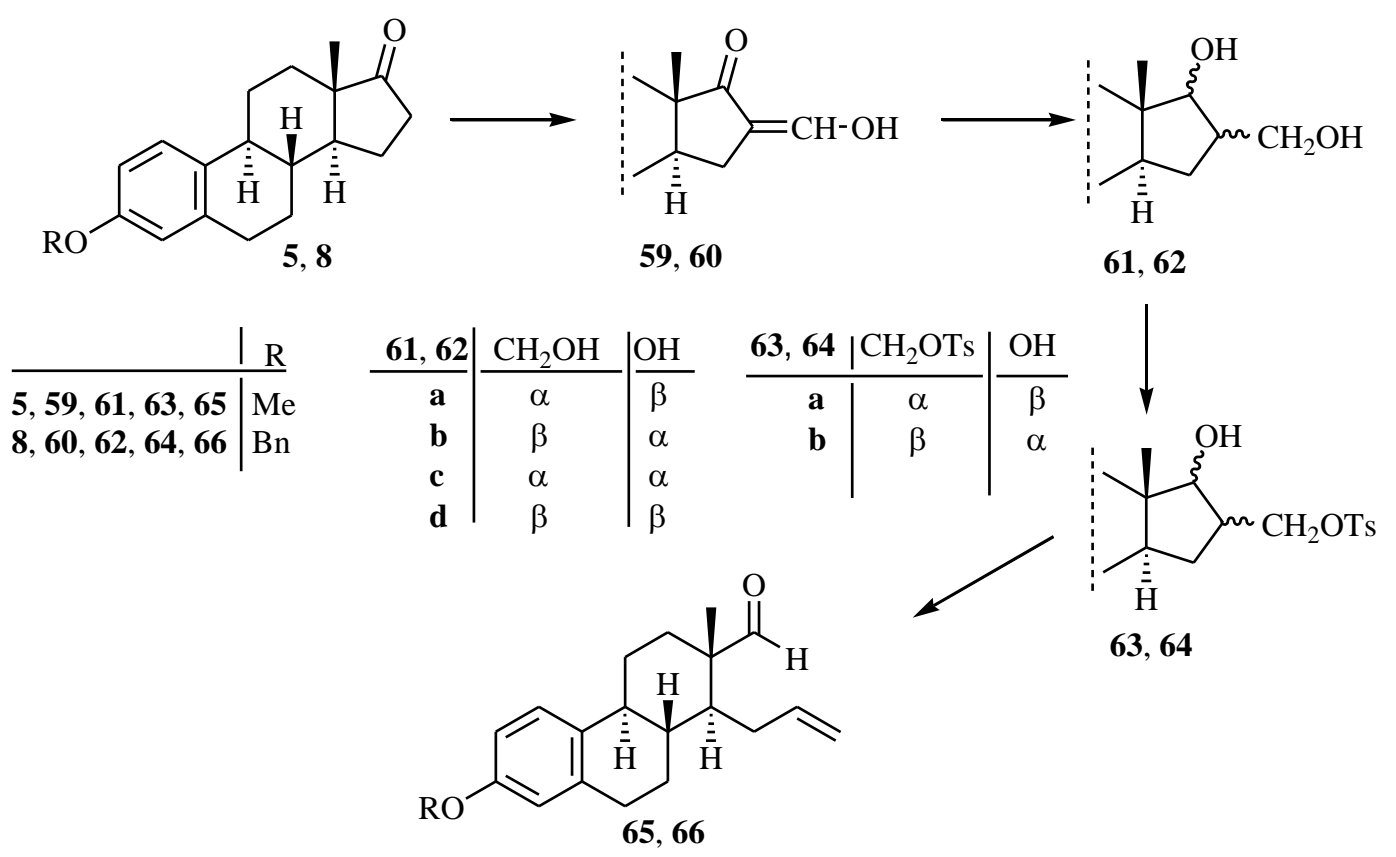

22. ábra: A D-szekoaldehidek $(\mathbf{6 5}, \mathbf{6 6})$ szintézise

A D-szekoaldehidet (65) hidroxilamin-hidrokloriddal oximmá (67) alakították (23. ábra) ${ }^{55} \mathrm{Az}$ aldoximból (67) Lewis-sav katalizátor $\left(\mathrm{BF}_{3} \cdot \mathrm{OEt}_{2}\right)$ hatására nitront (68) képeztek. A dipólus (68) szintézisét intramolekuláris 1,3-dipoláris cikloaddíció követte. A gyürűzáródás sztereoszelektíven ment végbe, és a 23. ábrán látható izoxazolidin származékot (70) nyerték. A ciklizáció Lewis-sav katalizátor nélkül is megvalósítható $N$-metilhidroxilamin- 
hidrokloriddal. Az így képződött nitron (69) a propenil-oldallánc kettős kötésével $(\mathrm{C}=\mathrm{C}$ dipolarofil) intramolekuláris 1,3-dipoláris cikloaddícióban $N$-metilizoxazolidin származékká (71) alakult. A ciklizáció ebben az esetben is sztereoszelektívnek bizonyult.<smiles>C=CC[C@H]1[C@H]2CCc3cc(OC)ccc3[C@@H]2CC[C@@]1(C)C=O</smiles>

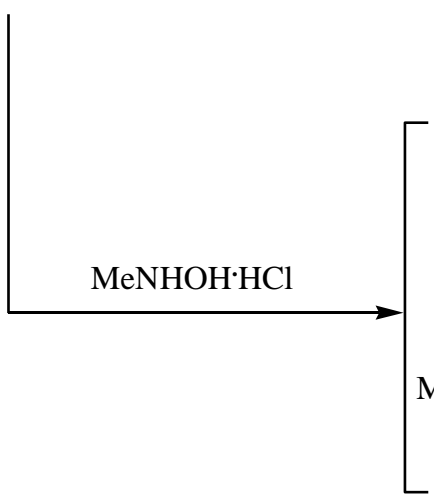<smiles>C=CC[C@H]1[C@H]2CCc3cc(OC)ccc3[C@@H]2CC[C@@]1(C)/C=N/O</smiles>
$\mathrm{BF}_{3} \cdot \mathrm{OEt}_{2}$

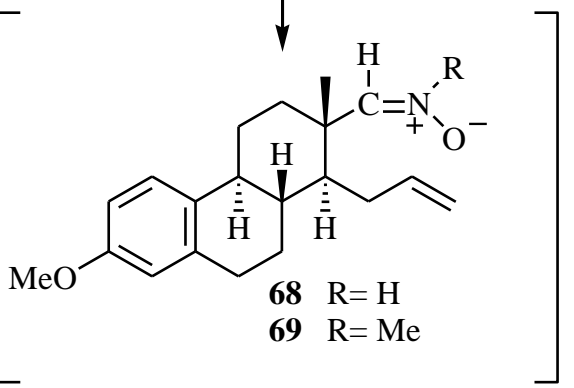

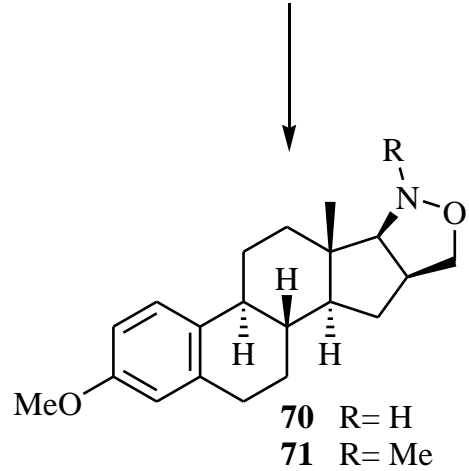

23. ábra: Ösztránvázas izoxazolidinok (70-71) előállítása Lewis-sav-indukált 1,3-dipoláris cikloaddícióval

\subsubsection{Azid dipólusok elöállitása és 1,3-dipoláris cikloaddíciói}

Disszertációm folytatásában azid típusú dipólusok cikloaddíciós reakcióit tárgyalom. Az azidok a propargil-allenil típusú dipólusok közé tartoznak (24. és 25. ábra). Ezek négy $\pi$ elektront tartalmazó delokalizált rendszert alkotnak, a dipólus síkjában lévő betöltött $\pi$-pálya miatt lineáris alkatúak. Három mezomer szerkezetük írható fel. A $\pi$-elektronok formális vándorlásával, amelyből kettőnél a $b$ az ,ónium” centrum, és az $a$ illetve a $c$ atom hordozza a 
negatív töltést. Ezekből származtatható egy olyan mezomer-szerkezet, amelyben a $b$ központi atom semleges, és az $a$-atom a pozitív, míg a $c$-atom a negatív töltést hordozza. A propargilallenil típusú rendszerek központi atomként (b) kizárólag nitrogént tartalmaznak.

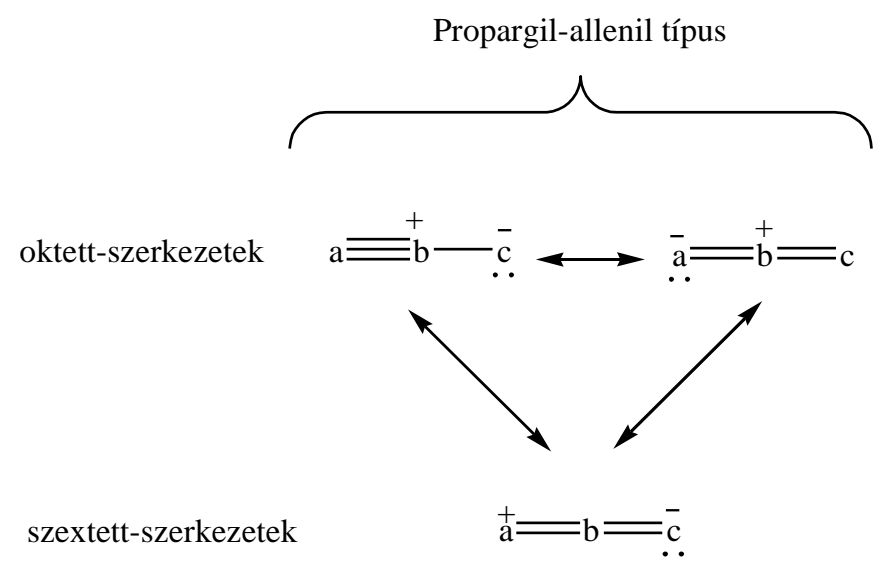

24. ábra: A propargil-allenil típusú dipólus mezomer szerkezetei

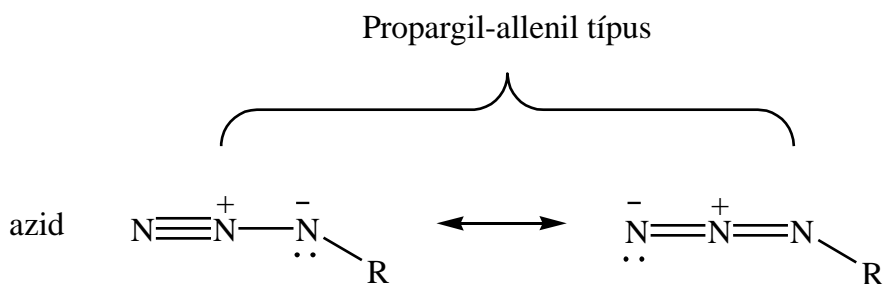

25. ábra: Az azid, mint 1,3-dipólus

Az azid dipólusok alkin dipolarofilekkel való reakciói már az 1960-as évektől ismertek az irodalomban. ${ }^{42,60,61}$ A [3+2]-cikloaddíciók során triazolok képződnek, ahol az azid, mint propargil-allenil típusú 1,3-dipólus reagál az alkin dipolarofillel. A „,click-reakció” fogalmát a 2000-es évek elején vezették be, amely jellemzője, hogy kisebb szerkezeti elemek összekapcsolásával, kedvező reakciókörülmények között, jó sztereo- és régioszelektivitással állíthatók elő a kívánt vegyületek. ${ }^{62}$ Kolb, Finn, és Sharpless mutattak rá a „,click-kémia” környezetbarát jellegére, így az oldószer nélküli, vagy vizes közeg alkalmazására, a magas hozam elérésére, és a nagy szelektivitásra. ${ }^{62} \mathrm{Az}$ azidokkal való munka azonban fokozott óvatosságot igényel. Kis mechanikai behatásra, vagy magas hőmérsékleten ugyanis nitrogén elimináció mellett robbanásszerüen bomlanak. Alkin-azid 1,3-dipoláris cikloaddícióval 
Huisgen és munkatársai foglalkoztak behatóbban. ${ }^{61}$ Magas hőmérsékleten $\left(80-120{ }^{\circ} \mathrm{C}\right)$ a 26. ábrán látható régioizomereket $(\mathbf{7 4 , 7 5})$ nyerték azonos arányban.

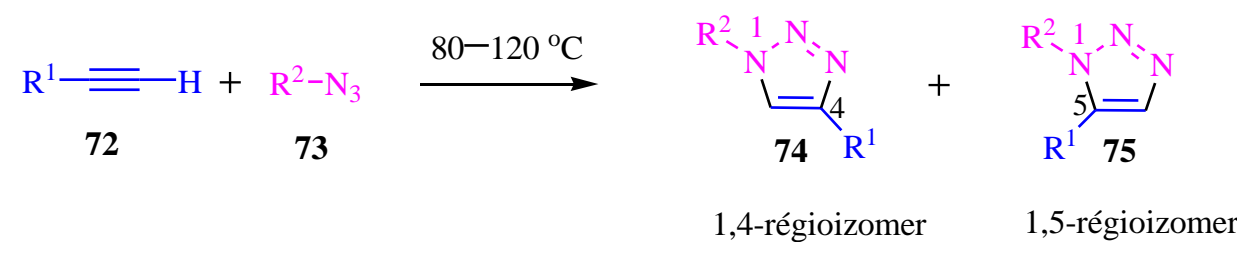

26. ábra: A Huisgen-féle 1,3-dipoláris cikloaddíció

A ,click-reakciót” Sharpless ${ }^{63}$ és Meldal ${ }^{64}$ kutatócsoportja egymástól függetlenül, ugyanabban az évben fejlesztette ki, amely a $\mathrm{Cu}(\mathrm{I})$-ion katalizált azid-alkin cikloaddícióként (CuAAC) vált ismertté. A réz(I)-katalizátor a reakciósebességet mintegy hét nagyságrenddel növeli, továbbá az 1,4-régioizomer képződésének kedvez. A katalitikus folyamat előnye az is, hogy széles hőmérséklet- $\left(0-160{ }^{\circ} \mathrm{C}\right)$ és $\mathrm{pH}$-tartományban $(\mathrm{pH}=4-12)$ megvalósítható. A $\mathrm{Cu}(\mathrm{I})$-iont vagy közvetlenül adják a reakcióelegyhez $\mathrm{CuI}^{65,66}$ vagy $\mathrm{CuBr}^{67}$ formájában, vagy in situ állítják elő $\mathrm{Cu}(\mathrm{II})$-ionok redukciójával. ${ }^{24,}{ }^{68-70} \mathrm{Ha}$ réz(I)-só formájában visszük be a katalizátort, akkor szükségszerüvé válik az aminok (DIPEA, $\mathrm{Et}_{3} \mathrm{~N}$ ), vagy magasabb hőmérséklet alkalmazása. $\mathrm{Cu}(\mathrm{II})$-ion forrásként általában $\mathrm{CuSO}_{4} \cdot 5 \mathrm{H}_{2} \mathrm{O}$-ot használnak, amelyet egy redukáló ágens segítségével (nátrium-aszkorbát) alakítanak át $\mathrm{Cu}(\mathrm{I})$-ionná. Elemi rézforrást is használnak, amely akár forgács, vagy egy rézszál is lehet, így annak a felületén alakulnak ki a $\mathrm{Cu}(\mathrm{I})$-ionok. ${ }^{71,72}$ A gyorsító poliligandumok alkalmazása nem szükségszerü, de jelentősen növeli a reakciósebességet. ${ }^{73}$ Ilyenek például a többfogú $N$-donor segédanyagok, vagy a trifenilfoszfán. Az utóbbi hátránya az, hogy a folyamatot a Staudinger-reakció kísérheti. Ennek során az azid aminná alakulhat, így az egyik reakciópartner „hiánya” következtében nem megy végbe az 1,3-dipoláris cikloaddíció.

A ,click-reakció” feltételezhető mechanizmusának alapját a DFT-számítások adják. ${ }^{74}$ A folyamat első lépéseként a komplexált réz-ion (i) $\pi$-komplexet alakít ki a terminális acetilénnel (ii), amely jelentősen csökkenti az alkin (ii) pKa értékét, így az elég savassá válik ahhoz, hogy protonvesztés mellett réz(I)-acetiliddé (iii) alakuljon (27. ábra). A rézkomplexről (i) ugyanekkor egy ligandumot is leszorít az alkin (ii). A következő lépésben (B) az azid (iv) negatív töltést hordozó $N$-atomja koordinálódik a réz-acetilidhez (iii), egy újabb ligandumot leszorítva a réz-komplexről. Az azid (iv) terminális nitrogénje ezek után nukleofil 
támadást indít az acetilén C-2 szénatomjára, és intramolekuláris gyürüzárás eredményeként egy hattagú réz-metallaciklus (vi) jön létre. Az intermedier (vi) képződése endoterm folyamat, és kisebb aktiválási energiát igényel, mint a katalizátor nélküli folyamat, ezzel magyarázható a hét nagyságrendbeli sebességnövekedés. A mechanizmus utolsó lépésében (D) gyürüszüküléssel alakul ki a $\mathrm{Cu}(\mathrm{I})$-triazolil komplex (vii), majd ennek protonálódásával (E) jön létre a kívánt triazol (viii) a katalizátor aktív formájának regenerálódása mellett.

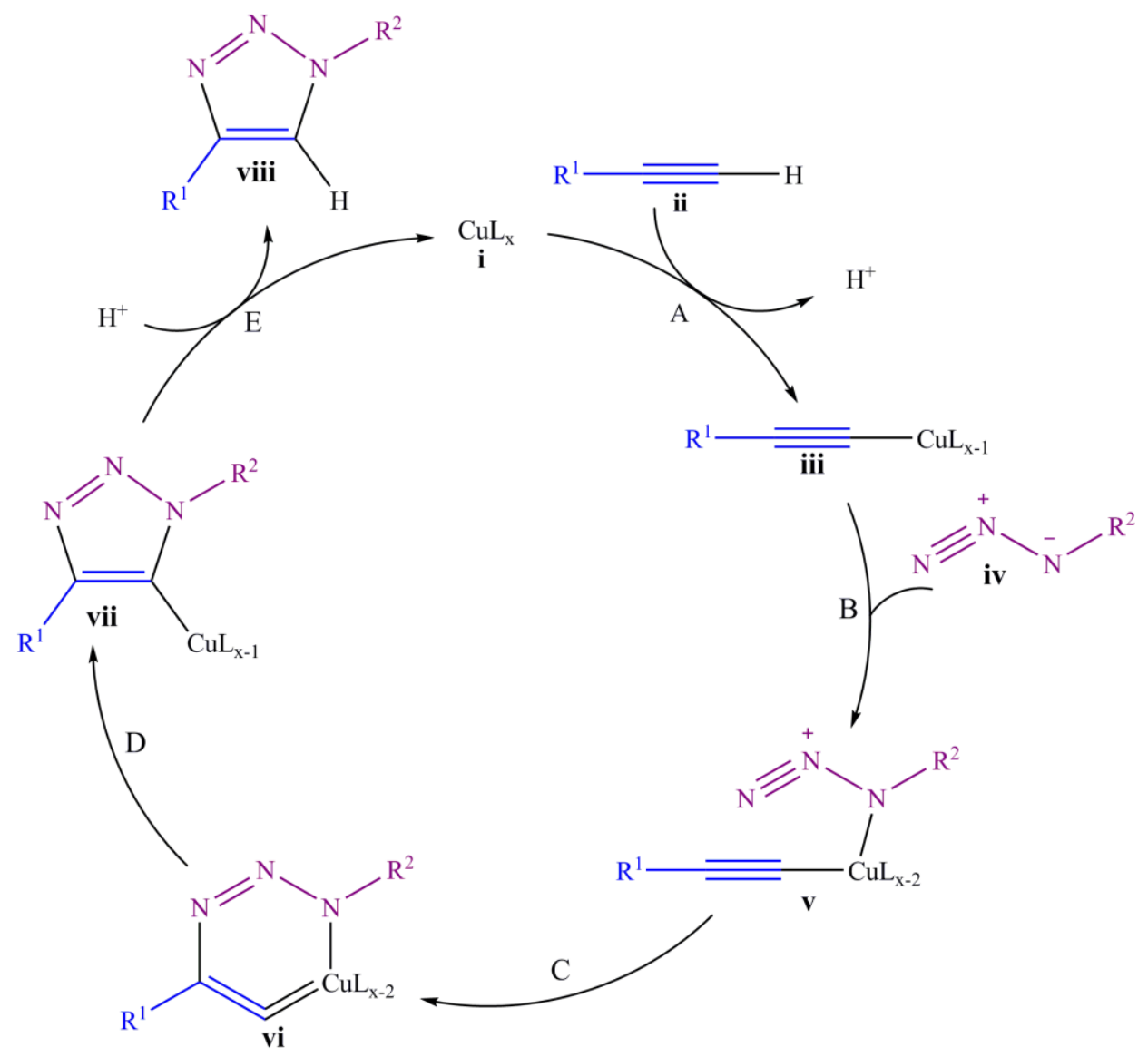

27. ábra: A „click-reakció” feltételezett körfolyamata

A CuAAC reakciók lehetővé teszik oldószerek, oldószerelegyek széleskörü alkalmazását, amelyek apoláris és poláris jellegüek egyaránt lehetnek. Meldal és Tornøe vizsgálták az oldószereknek a reakciókra gyakorolt hatását. ${ }^{75}$ A reakciók gyors lefutása érdekében olyan oldószert érdemes választani, amely a katalizátor szolvatálódását elősegíti. A poláris oldószer a heterociklusok kiépülésének kedvez. Amennyiben a szubsztrát apoláris jellegü, akkor a toluol, vagy a tetrahidrofurán a megfelelő oldószer. ${ }^{76}$ 
Azid dipólusokat szteroid modellen a közelmúltban több kutatócsoport is elöállított. ${ }^{28-}$ 33, 77-83 Az azid-funkció kiépítésének legismertebb módszerei: az epoxidnyitás, a halogén-azid csere, az $\alpha, \beta$-telítetlen ketonok 1,4-Michael addíciója, illetve a 16-os vagy 17-es helyzetben lévő hidroxil-funkció jó kilépő csoporttá történő átalakítása TsCl-dal, és az azt követő $\mathrm{S}_{\mathrm{N}} 2$ szubsztitúciós reakció $\mathrm{NaN}_{3}$-dal. ${ }^{33}$ Schönecker és munkatársai az azidok (77-79) szintézisét epoxidok gyürűnyitásával valósították meg (28. ábra). ${ }^{77-79} \mathrm{Az}$ ösztron-3-metil-éterből (5) egy többlépéses reakciósort követve nyerték a szteroid-olefint (76). Az alkénből (76) epoxidálást, majd az epoxid nátrium-aziddal történő gyürünyitását követően azidoalkohol (77-79) régioizomereket állítottak elő.

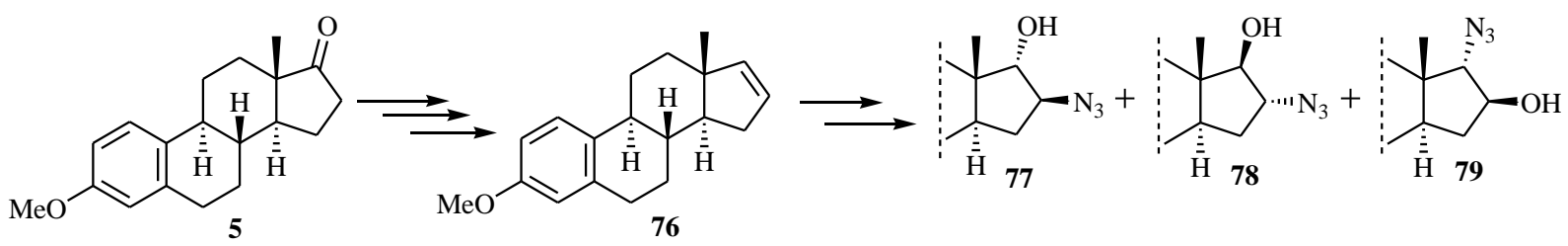

28. ábra: Azidoalkoholok (77-79) előállítása

A Szerves Kémiai Tanszék Szteroid Kutatócsoportja számos alapvázon, különböző helyzetbe építettek be triazolil-funkciót. ${ }^{28-32,82,83}$ A cél a CuAAC reakciók optimalizálása, a reakcióidők csökkentése, a magas hozamok elérése és a régiószelektív szintézisek kidolgozása volt. A 81-es jelü vegyületet a 15ß,17ß-azidoalkoholokból kiindulva CuAAC reakció alkalmazásával (29. ábra), különbözően szubsztituált terminális acetilének felhasználásával alakították ki. $\mathrm{Cu}(\mathrm{I})$ forrásként CuI-ot használtak, trifenilfoszfán komplexáló ligandum, és diizopropil-etilamin (DIPEA) bázis mellett. A 70-75\%-os hozamok elmaradtak a „clickreakcióknál" megszokott magas értékektöl. Azt tételezték fel, hogy a 17ß-hidroxilcsoport és a 15ß-azido-funkció azonos térállása rontotta a cikloaddíciós átalakítások hozamát. A 82-es és a 83-as jelü vegyülethez transz- illetve cisz-térállású azidoalkoholok CuAAC reakciójával jutottak. Megfigyelték, hogy a 81-es vegyület esetében alkalmazott reakciókörülmények mellett, a toluol forráspontján végezve az 1,3-dipoláris cikloaddíciókat, mindkét azidoalkohol esetében régiószelektíven mennek végbe a gyürüzárások. A transz származékoknál (82) 90\% feletti, míg a cisz származékoknál (83) csupán 60\% körüli hozamokat tapasztaltak. A 84-es vegyület szintézise során kizárólag 1,4-diszubsztituált vegyületeket nyertek, továbbá a „clickreakcióhoz" szükséges $\mathrm{Cu}(\mathrm{I})$-ionokat in situ generálták $\mathrm{CuSO}_{4} \cdot 5 \mathrm{H}_{2} \mathrm{O}$ és Na-aszkorbát 
segítségével. Ezen vegyület (84) alkalmazásának előnye, hogy a 3-as helyzetű acetoxicsoport bázikus közegü hidrolízisével szabad hidroxil-funkcióhoz jutottak, amely hozzájárult a vegyület (84) kedvező biológiai aktivitásához. A 85-ös származékok előállítása esetén toluol helyett a diklórmetán forráspontján végezték az átalakításokat, trifenilfoszfán komplexáló ligandum mellett, bázis jelenléte nélkül. A gyürüzárások 24 óra alatt végbementek, régiószelektíven szolgáltatva a $\mathbf{8 5}$-ös androsztánvázas vegyületeket.

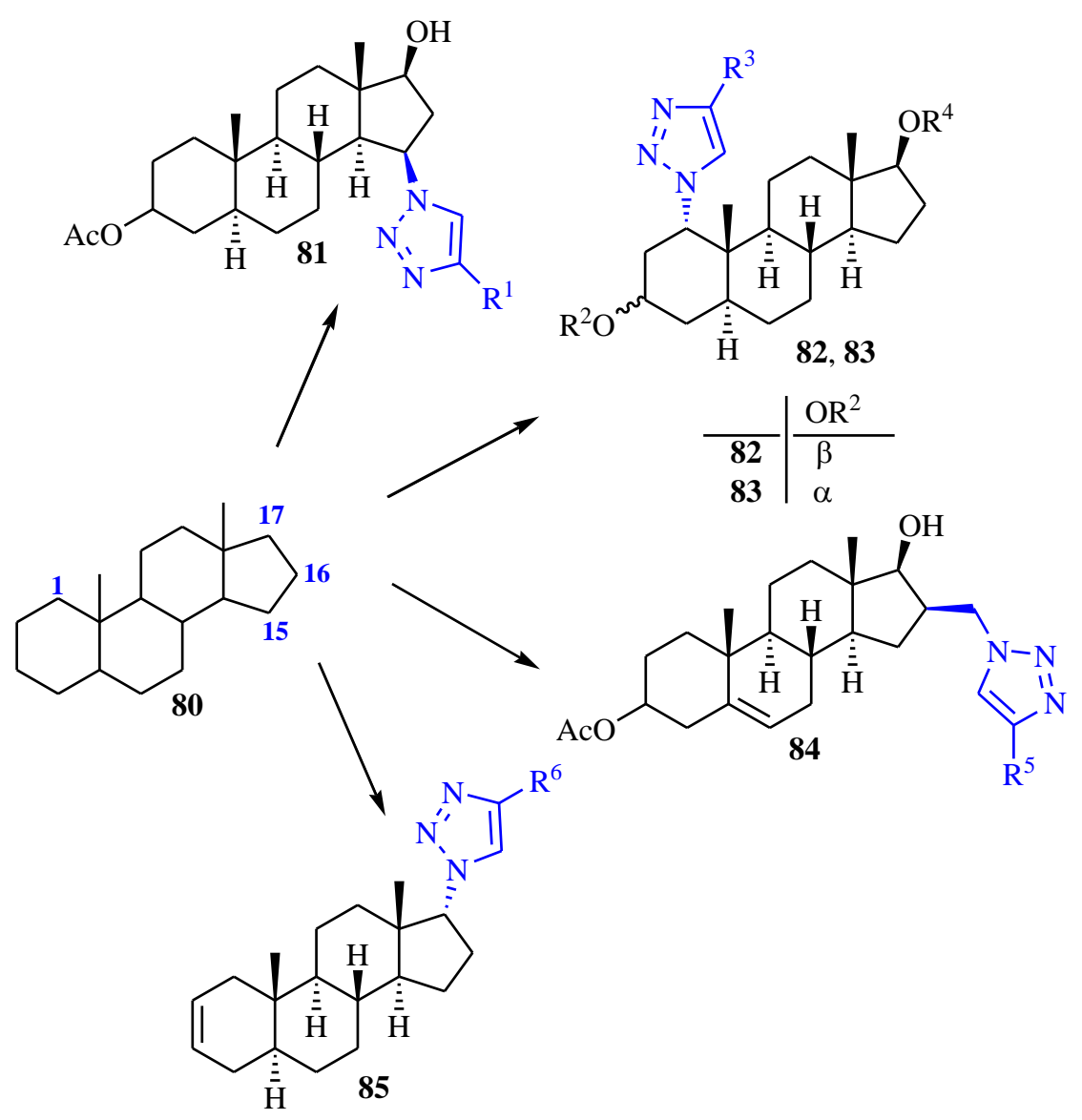

29. ábra: Triazolil-funkció beépítése az androsztánvázra (kék)

Kutatócsoportunk az androsztánvázas származékok (81-85) mellett a kolesztánvázas szteroidok azid-alkin-típusú cikloaddíciós reakcióit is végrehajtotta (30. ábra). ${ }^{29}$ A $2 \alpha-$ azidoketont (86) különbözőképpen szubsztituált terminális acetilénekkel (72) reagáltatták. Kétfázisú oldószerelegyet alkalmaztak $\left(\mathrm{CH}_{2} \mathrm{Cl}_{2} / \mathrm{H}_{2} \mathrm{O}\right)$, a $\mathrm{Cu}(\mathrm{I})$-iont az androsztánvázas származékoknál (84) ismertetett módszer szerint in situ generálták. 


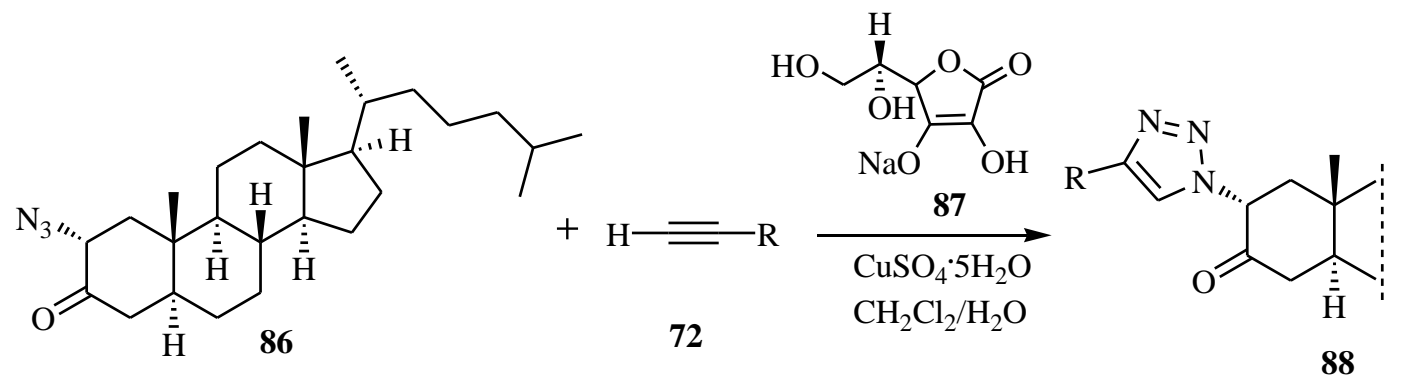

30. ábra: A kolesztánvázas triazolil származékok (88) előállítása

Az ösztránvázas triazolok szakirodalma ugyancsak számos példát ismer. ${ }^{33,80-83}$ Lipschutz és Taft olyan CuAAC reakciókat hajtott végre, amelyek során $\mathrm{Cu} / \mathrm{C}$ katalizátort alkalmaztak. $^{80}$ A $17 \alpha$-etinilösztradiolt választották modellvegyületként. Az 1,3-dipoláris cikloaddíció eredményeként jó hozammal nyerték a 31. ábrán látható 90-es jelü vegyületet. Alonso és munkatársainak kiindulási anyaga ugyancsak a $17 \alpha$-etinilösztradiol volt, viszont a benzil-aziddal történő „click-reakció” során nanoszemcsés rézkatalizátort alkalmaztak trietilamin bázis jelenlétében. ${ }^{81} \mathrm{Az}$ intermolekuláris gyürüzárás során régiószelektíven, rövid idő alatt nyerték a cikloadduktumot (91). A Szerves Kémiai Tanszék Szteroidkémiai Kutatócsoportja az ösztránváz különböző helyén kapcsolódó triazolil származékot szintetizált. ${ }^{33,82,83} \mathrm{Az}$ így előállított vegyületek antitumor hatását is vizsgálták. A 13 $\alpha$-ösztron sorban két transz-diasztereomert, a 16 $\alpha, 17 \beta$ - (92) és 16 $\beta, 17 \alpha$-származékot (93) szintetizáltak. A $13 \beta$-sorban $17 \alpha-(94)$, valamint $15 \beta$-triazolokat (95, a 17-es szénatomon hidroxil- vagy acetoxicsoport) állítottak elő. Az átalakításokra jellemző, hogy CuI katalizátor alkalmazásával, DIPEA és $\mathrm{PPh}_{3}$ jelenlétében, diklórmetán vagy toluol forráspontján játszódtak le. A közelmúltban a 17-(5'-jód)triazolil epimerek (96 - 17 $\alpha$-triazolil, 97 - 17 triazolil) szintézisét is megvalósították. A jód kationnak az 5'-helyzetbe való beépülését trietilamin jelenlétében figyelték meg. A kutatócsoportunk által előállított ösztránvázas triazolok biológiai jelentőségét az adja, hogy számos képviselöjük hatékony antiproliferatív vegyületnek bizonyult. 


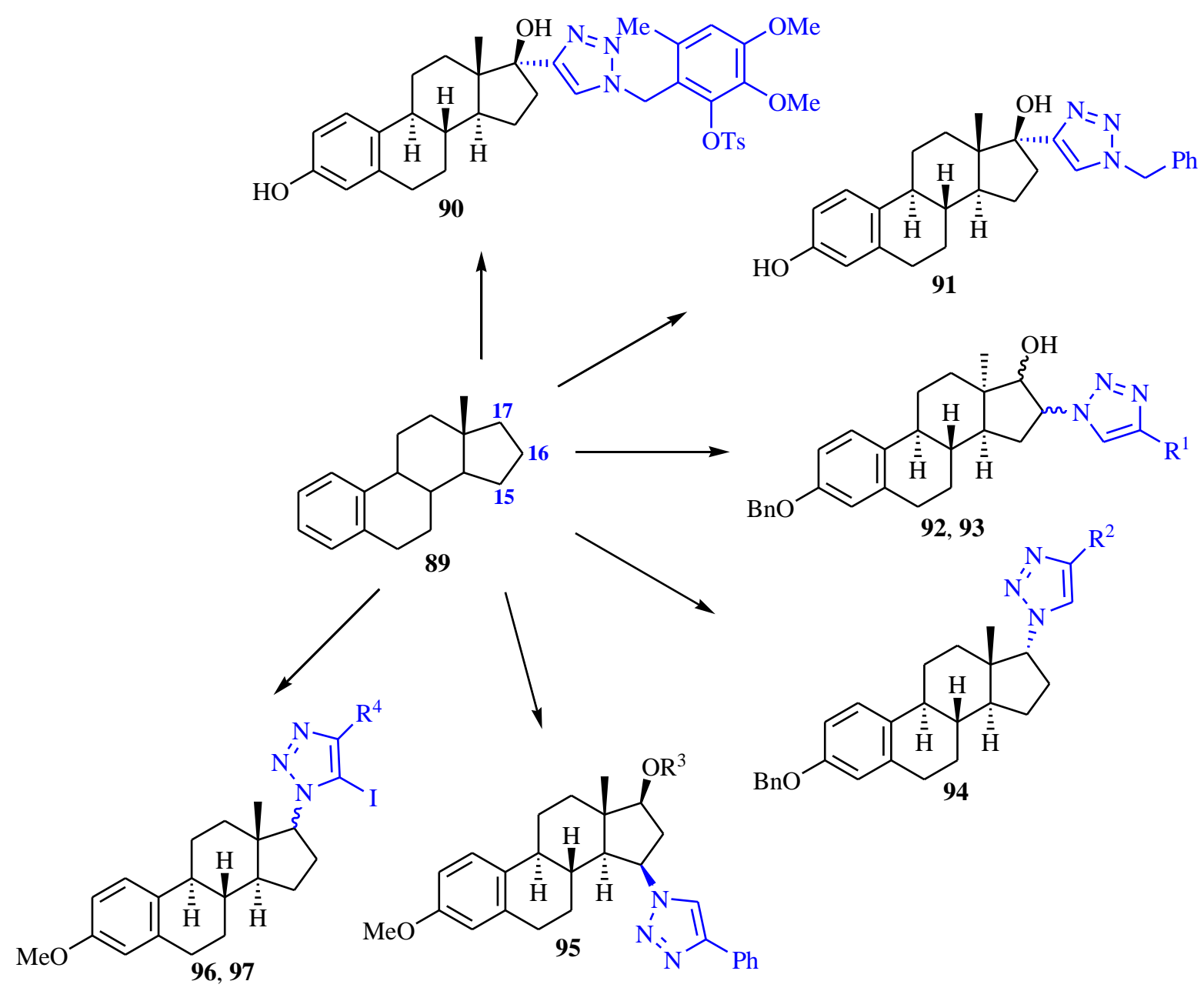

31. ábra: Ösztránvázas triazolok (90-97) 


\subsubsection{A Prins-Ritter-reakció}

\subsubsection{A Prins-reakció}

A Prins-reakció egy protonált karbonilvegyületnek alkénre vagy alkinre történő addíciója. ${ }^{84} \mathrm{~A}$ reakciómechanizmus értelmezése szerint a Prins-reakcióban az oxovegyületek Lewis-, vagy Brønsted-sav jelenlétében alkénekkel reagálnak, és az így kialakuló $\beta$-karbokation többféle módon alakulhat tovább. Ez történhet egyszerű nukleofil-támadással, másrészt protonvesztéssel, vagy egy újabb molekula oxovegyülettel való reakcióval. A Prinsreakciónak ismeretes intra-, illetve intermolekuláris változata is. Az intramolekuláris folyamatban ugyanazon molekulán lévő funkciós csoportok reagálnak egymással, és az azt követő gyürüzárás eredményeként öt, hat és héttagú származékok alakíthatók ki. ${ }^{85-87}$

Szteroidkémiai Kutatócsoportunk a közelmúltban a kiindulási anyagként használt $13 \alpha-$ epimer D-szekoaldehidek szintézisét valósította meg, hasonló reakcióuton, mint 13ßmegfelelöiket. $^{58,59,79,88-91}$ Schönecker és munkatársai a 3-as helyzetben védett ösztron származékokat $(\mathbf{5}, \mathbf{8})$ egylépésben epimerizálták $o$-feniléndiamin segítségével, jégecetes közegben. Kutatócsoportunk ezen kidolgozott eljárást továbbfejlesztve jutott a 32. ábrán látható 13a-származékokhoz $(\mathbf{9 8}, 99)$, amelyekből többlépéses reakciósorban, Grobfragmentációt alkalmazva kulcslépésként, nyerték a cisz-helyzetü oldalláncokat tartalmazó 13 $\alpha$-D-szekoaldehideket $(\mathbf{1 0 2}, \mathbf{1 0 3})$.
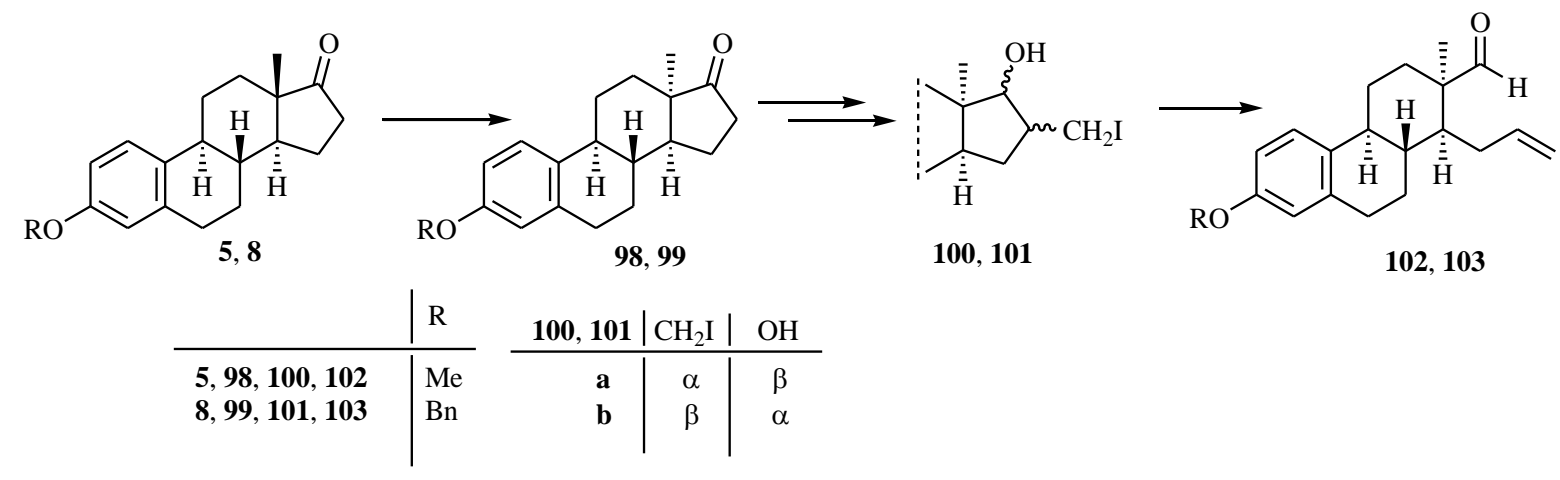

102,103

32. ábra: A $13 \alpha-D$-szekoaldehidek $(\mathbf{1 0 2}, \mathbf{1 0 3})$ előállítása

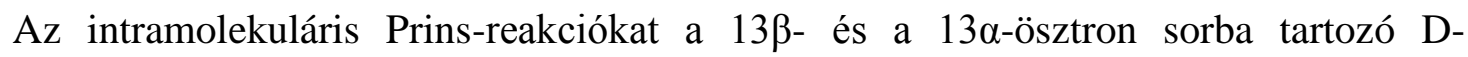
szekoaldehidekkel $(\mathbf{6 5}, \mathbf{6 6}, \mathbf{1 0 2})$ hajtották végre, Lewis-savakat alkalmazva katalizátorként 
(33. ábra). ${ }^{92}$ A 13ß-ösztron sorban a D-szekoaldehidek $(65,66)$ gyürüzárását diklórmetános közegben, 1,1 ekvivalens mennyiségü Lewis-savval $\left(\mathrm{BF}_{3} \cdot \mathrm{OEt}_{2}, \mathrm{SnCl}_{4}, \mathrm{ZnBr}_{2}\right)$ valósították meg. A reakciók kemoszelektíven játszódtak le, minden esetben 16-halo-17a-hidroxi (105108, 110-113) vagy 16-halo-17a-etoxi származékokat (104, 109) eredményezve.

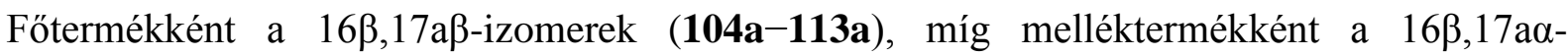
származékok (104b-113b) képződtek. $\mathrm{BF}_{3} \cdot \mathrm{OEt}_{2}$-ot alkalmazva 16 $\alpha$-fluorszármazékok is képződtek. Ez a fluoratom kis méretével magyarázható, hogy mindkét oldalról indíthat nukleofil támadást a 16-os karbokationra. $\mathrm{BF}_{3} \cdot \mathrm{OEt}_{2}$ hatására a 17a-hidroxil-funkció átéteresítését $(\mathbf{1 0 4}, \mathbf{1 0 9})$ is tapasztalták. A 13 $\alpha$-ösztron sorban a reakciók minden esetben sztereoszelektíven a 16, 17 a $\alpha$-D-homoszteroidokat (114-117) szolgáltatták. Abban az esetben, amikor Lewis-savként $\mathrm{ZnBr}_{2}$-ot alkalmaztak, a halohidrinek (114-117) mellett homoallil-alkoholt (118) is izoláltak. A 13ß-ösztron származékoknál (65, 66) a NaI-dal történő átalakítás esetében katalitikus mennyiségü $\mathrm{BF}_{3} \cdot \mathrm{OEt}_{2}$ alkalmaztak, azonban a $13 \alpha-$ ösztron sorban csupán 1,1 ekvivalens mennyiséggel ment végbe ugyanezen reakció. Megfigyelték továbbá, hogy a 13a-szekoaldehid (102) gyürüzárási reakcióinak sebessége csökkent, ugyanekkor a sztereoszelektivitása nőtt a 13ß-származékokéhoz $(\mathbf{6 5}, \mathbf{6 6})$ képest. 


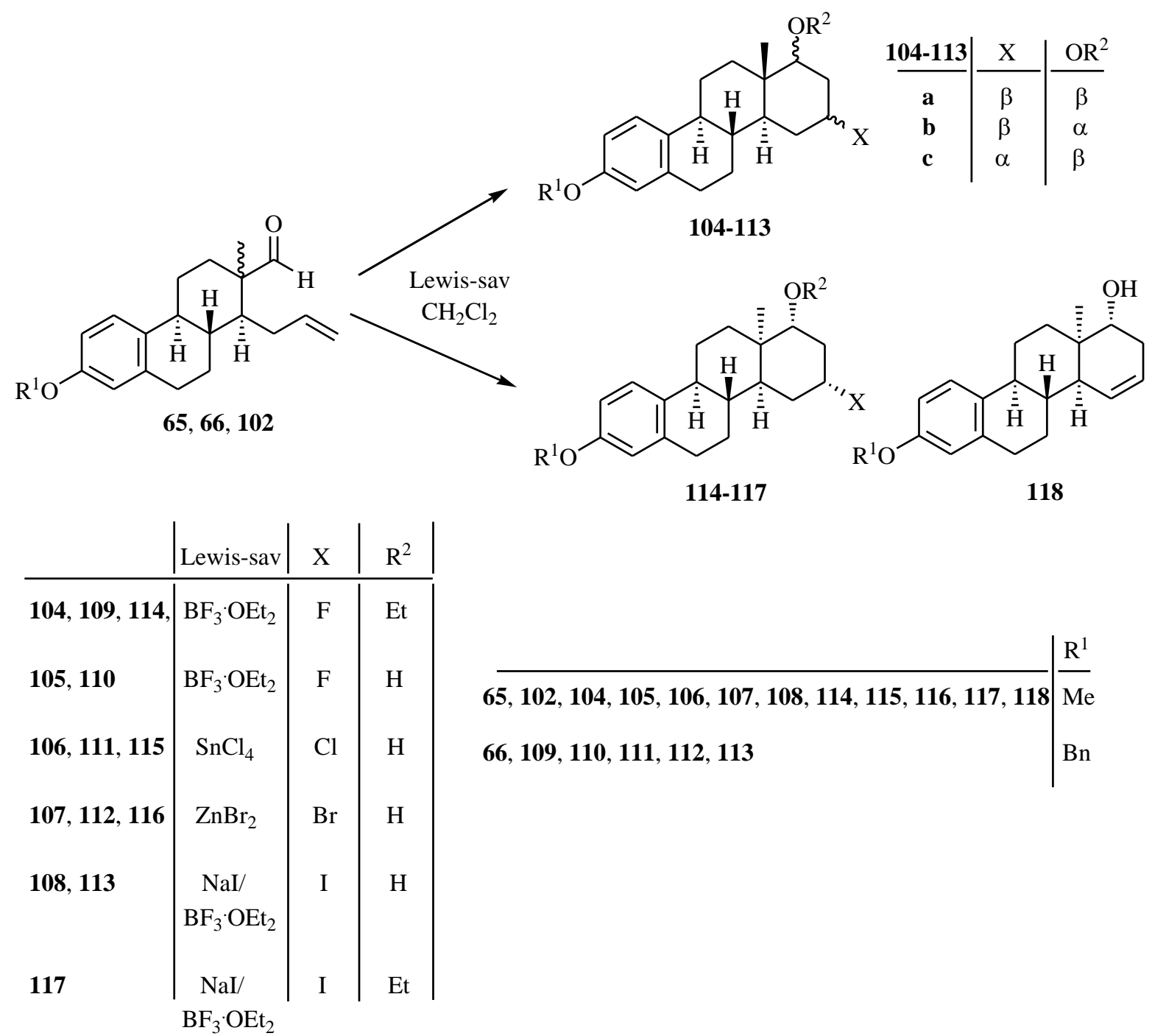

33. ábra: Lewis-sav-indukált Prins-reakció a $13 \alpha$ - és a 13ß-ösztron sorban

\subsubsection{A Ritter-reakció}

A múlt század közepén Ritter és munkatársai új módszert ismertettek a savamidok $(\mathbf{1 2 2}, \mathbf{1 2 3})$ szintézisére, amely Ritter-reakció néven vált ismertté (34. ábra) ${ }^{93}$ Ezen folyamat során tercier alkoholból (119), vagy olefinből (120) nitril $(\mathbf{1 2 1})$ hatására savamidok $(\mathbf{1 2 2}, \mathbf{1 2 3})$ képződnek. Az alkohol (119) savamiddá (122) történő átalakulásának feltételezett mechanizmusát a 34. ábra szemlélteti. Az in situ képződő karbokationra (124) a nitril (121) nukleofil támadást indít, így kialakul a nitrílium-ion (125), amelynek hidrolízise savamidot (122) eredményez. A Ritter-reakció általában ekvivalens mennyiségü erős savat igényel. Így a savérzékeny 
funkciós csoporttal rendelkező vegyületek jelentősen korlátozzák ezen reakciótípus alkalmazhatóságát.

$\mathrm{R}^{2} \underset{\mathrm{R}^{3}}{\stackrel{\mathrm{OH}}{\mathrm{R}^{4}}}$

119

$+\mathrm{R}^{1}-\mathrm{C} \equiv \mathrm{N}$

121<smiles>[R]C=C([R])[R]</smiles>

120<smiles>[R]C(=O)NC([R])([R])[R]</smiles>

122

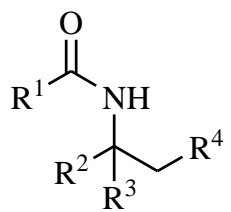

123

Mechanizmus:

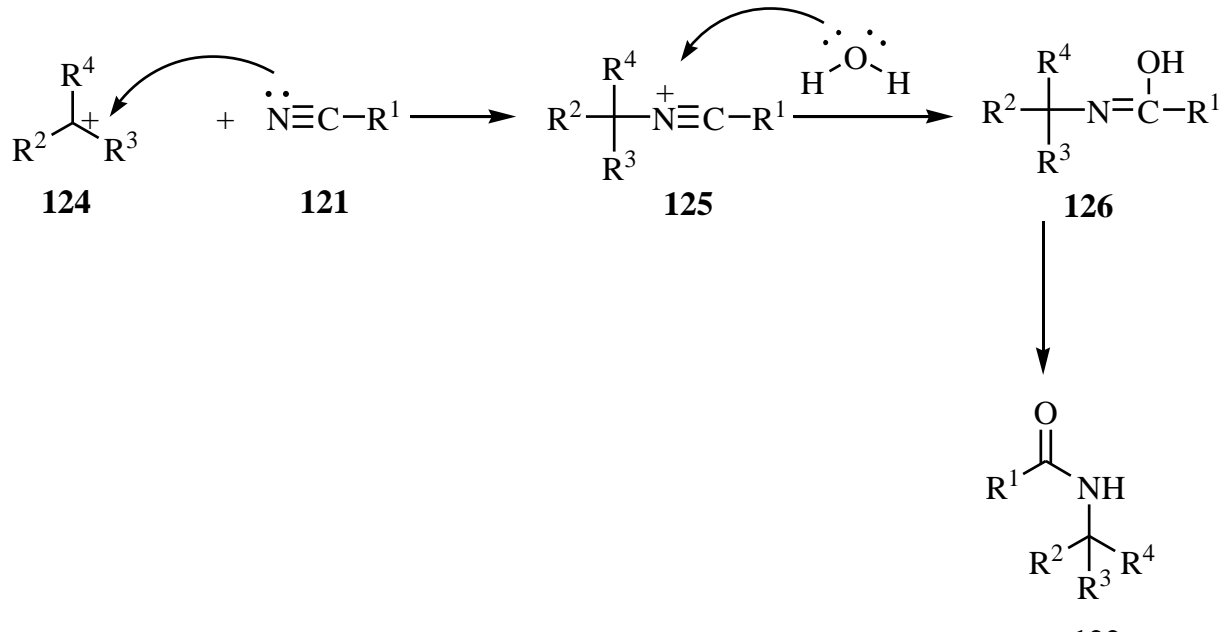

122

34. ábra: A klasszikus Ritter-reakció 
A Ritter-reakció a Brønsted-savak mellett Lewis-savvakkal is katalizálható. Badparva és munkatársa 1994-ben számoltak be előszőr a benzilalkohol (127) $\mathrm{BF}_{3} \cdot \mathrm{OEt}_{2}$-tal (Lewis-sav) katalizált savamidképzéséről (35. ábra). ${ }^{94}$

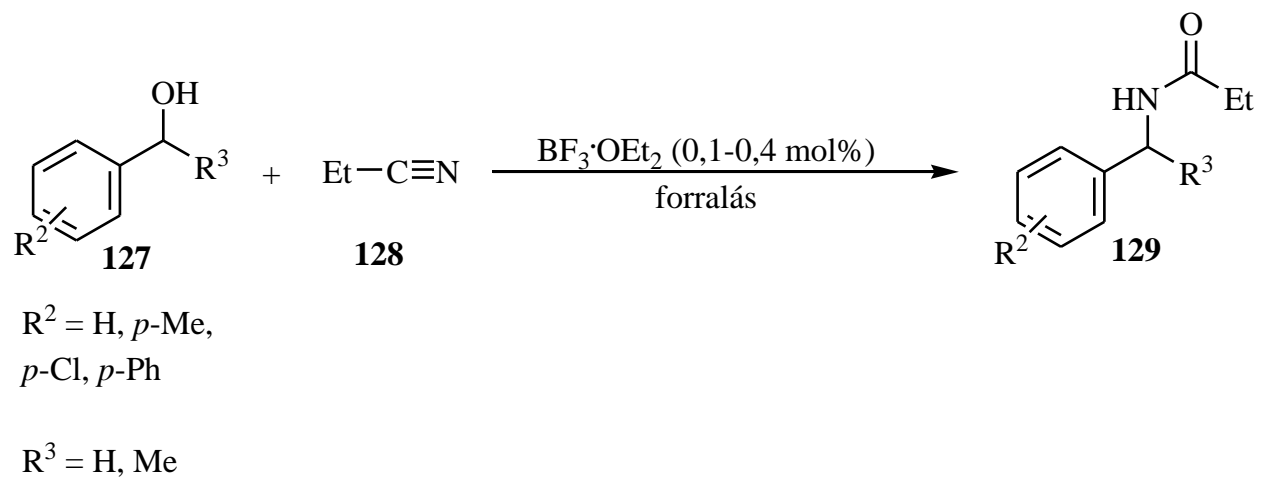

35. ábra: Lewis-sav-katalizált Ritter-reakció

\subsubsection{A ,one pot” Prins-Ritter reakció:}

A Prins-Ritter reakció lehetőséget nyújt acilamino-funkciónak karbokationra való kiépítésére. $^{95-102}$ Yadav és munkatársai multikomponensű „one pot” szintézismódszert alkalmaztak a 4-acetamidotetrahidropirán származék (133) előállítására (36. ábra). ${ }^{98-100,102}$ Karbonil-vegyületből (130) és homoallil-alkoholból (132) kiindulva, acetonitril jelenlétében, szobahőmérsékleten hajtották végre a reakciókat. ${ }^{99}$ Lewis-sav katalizátorként 20 mol\% foszformolibdénsavat (PMA) használtak, és jó hozammal, cisz-szelektivitással nyerték a terméket (133). Savkatalízishez gyakran alkalmaznak még $\mathrm{BF}_{3} \cdot \mathrm{OEt}_{2}$-ot, $\mathrm{B}\left(\mathrm{C}_{6} \mathrm{~F}_{5}\right)_{3}$-ot, $\mathrm{Bi}(\mathrm{OTf})_{3}$-ot, és $\mathrm{CeCl}_{3} \cdot 7 \mathrm{H}_{2} \mathrm{O} / \mathrm{AcCl}$-ot. ${ }^{95-102} \mathrm{~A}$, one pot” Prins-Ritter reakció elönye, hogy az egyszerre felhasznált komponenseknek köszönhetően azonnal a képződő 4acetamidotetrahidropirán származékokat $(\mathbf{1 3 3}, \mathbf{1 3 4})$ nyerték. Selvam és kutatócsoportja $\mathrm{Ce}\left(\mathrm{SO}_{4}\right)_{2}$ katalizált három komponensü „one pot” Prins-Ritter szintézist hajtott végre. ${ }^{101}$ Számos Lewis-sav katalizátor $\left(\mathrm{ZnCl}_{2}, \mathrm{FeCl}_{3} \cdot 6 \mathrm{H}_{2} \mathrm{O}, \quad \mathrm{SnCl}_{2} \cdot 2 \mathrm{H}_{2} \mathrm{O}, \mathrm{KHSO}_{4}, \mathrm{H}_{3} \mathrm{PW}_{12} \mathrm{O}_{40}\right.$, $\left.\mathrm{Ce}\left(\mathrm{SO}_{4}\right)_{2}\right)$ közül a $\mathrm{Ce}\left(\mathrm{SO}_{4}\right)_{2}$ bizonyult a leghatékonyabbnak. A Prins-Ritter reakciót szobahőmérsékleten végezték, a 4-klórbenzaldehidből (131), homoallil-alkoholból (132), acetonitriles közegben diasztereoszelektíven nyerték a 4-acetamidotetrahidropirán származékot $(\mathbf{1 3 4}, 36$. ábra). 
<smiles>O=CC1CCCCC1</smiles>

130<smiles>O=Cc1ccc(Cl)cc1</smiles>

131

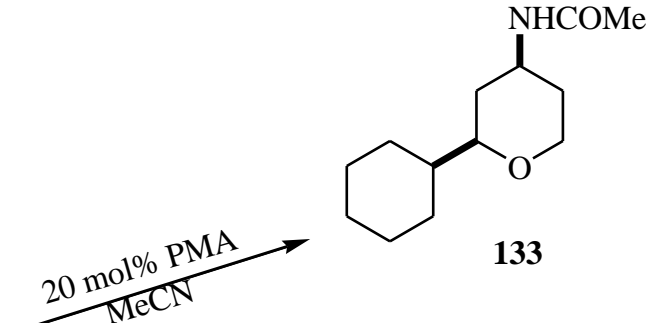<smiles>C=CCCO</smiles>

132<smiles>CC(C)(C)NC(=O)O</smiles><smiles>CC(=O)NC1CCOC(c2ccc(Cl)cc2)C1</smiles>

36. ábra: A „one pot” Prins-Ritter reakciók

A „one pot” Prins-Ritter reakciók szterán vázra való kiterjesztésével lehetőség nyílik a D-szekoaldehidek acilamino-szubsztituált homológjainak előállítására, amelyek értékes biológiai hatást hordozhatnak. 


\section{CÉLKITÜZÉS}

Munkánk célja olyan új ösztron származékok szintézise volt, amelyek hormonálisan inaktívak, azonban potenciálisan antitumor hatással rendelkeznek. Az ösztrogén hatás kiküszöböléséhez 13-epimer, D-szeko- vagy D-homoszármazékokat választottunk alapvegyületként, majd azokra szubsztituensek vagy nitrogéntartalmú heterociklusok beépítését terveztük. A heterociklusos gyürük kialakítását 1,3-dipoláris cikloaddíciós reakciókkal kívántuk megvalósítani, szteroid-nitron vagy -azid dipólusokból kiindulva. Célunk volt a folyamatok sztereo-, kemo- és régioszelektivitásának vizsgálata, és a céltermékek szerkezetének nagymüszeres analitikai módszerekkel (NMR, MS, röntgenkrisztallográfia) történő szerkezetvizsgálata. Az új vegyületek humán tumorsejtekre in vitro gyakorolt osztódásgátló hatását is vizsgálni kívántuk, továbbá a potens származékok hatásmechanizmusának felderítését is terveztük. 


\section{KÍSÉRLETI EREDMÉNYEK TÁRGYALÁSA}

\subsection{Az 1,3-dipoláris cikloaddíciók}

4.1.1. Nitronképzés Lewis-savakkal vagy elektrofil reagensekkel, és a nitronok 1,3-dipoláris cikloaddíciói

A Szerves Kémiai Tanszék Szteroidkémiai Kutatócsoportja korábban már végrehajtotta a Dszekoaldehid (65) Lewis-sav-indukált intramolekulás 1,3-dipoláris cikloaddícióját. ${ }^{55}$ Kísérleti munkánk első lépésében ugyanezen szintézismódszert terjesztettük ki a $13 \alpha$-epimerekre. ${ }^{103}$ Kiindulási vegyületünket, a 13 $\alpha$-D-szekoaldehidet (102) metanolos közegben, hidroxilaminhidrokloriddal, nátrium-hidroxid jelenlétében alakítottuk oximmá (135, 37. ábra). Melléktermékként dimetil-acetál (139) képződését tapasztaltuk. A metanol alkalmazása következtében lejátszódó mellékreakció elkerülése érdekében a továbbiakban acetonitrilt és nátrium-acetátot használtunk. $\mathrm{Az}$ oximképzést Lewis-sav-indukált $\quad\left(\mathrm{BF}_{3} \cdot \mathrm{OEt}_{2}\right)$ intramolekuláris gyürüzárás követte. A 13ß-sorban elvégzett szintézisekkel ellentétben nem egy, hanem két cisz-gyürüanellációval rendelkező izoxazolidin-sztereoizomerhez $(\mathbf{1 3 7}, \mathbf{1 3 8})$ jutottunk, a szintézis így nem bizonyult sztereoszelektívnek. A két származékot $(\mathbf{1 3 7}, \mathbf{1 3 8})$ azonos arányban nyertük. A két izomer (137, 138) képződése a 13 $\alpha$-származékok flexibilisebb vázszerkezetének tulajdonítható. Amennyiben a gyürüzárásokat $N$-metilhidroxilamin-hidrokloriddal végeztük, a 13ß-származékhoz hasonlóan, Lewis-sav-katalízis nélkül, egy sztereoizomer (139) képződését tapasztaltuk. 
<smiles>C=CC[C@H]1C(=O)[C@@H]2CCc3cc(OC)ccc3[C@H]2CC[C@H]1C</smiles>

102

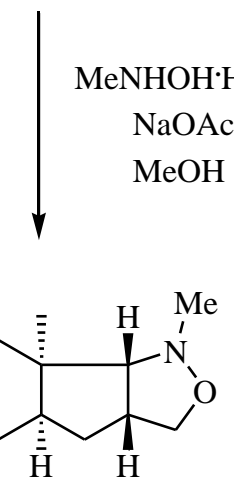

139

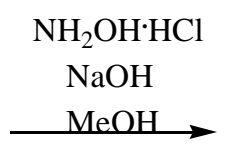<smiles>C=CCC(C)C(C)/C=N\O</smiles>

135<smiles>C=CCC(I)C(I)(I)C(OC)OC</smiles>

136
$\mathrm{BF}_{3} \cdot \mathrm{OEt}_{2}$

$\mathrm{Ph}-\mathrm{Me}$

37. ábra: Az izoxazolidin sztereoizomerek (137-139) elöállítása

A 38. ábrán látható az oxim (135) röntgendiffrakciós analízissel kapott szerkezete, amely ábra jól szemlélteti, hogy a vegyület C-gyürüje szék-alkatú, és az axiális oxim-funkció E-konfigurációjú.

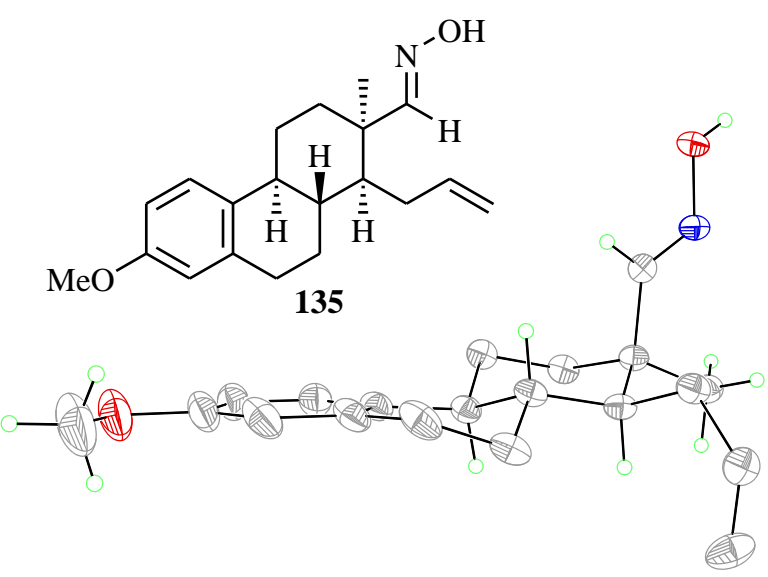

38. ábra: A 135-ös jelű vegyület röntgendiffrakcióval kapott szerkezete

NMR-spektroszkópiával végeztük az izoxazolidin sztereoizomerek (137-139) szerkezetbizonyítását. Mindhárom izoxazolidin (137-139) ${ }^{1} \mathrm{H}-\mathrm{NMR}$ spektrumából kitünik, hogy a D-szekoaldehid (102) propenil-oldalláncának a jelei (5 és 6 ppm között) és a formilproton jele $\left(9,5\right.$ ppm) is hiányzik. A 137 -es jelü vegyület ${ }^{1} \mathrm{H}-\mathrm{NMR}$ spektrumából jól látszik a 
17-H dublettje 3,5 ppm-nél, a 16-H multiplettje 3,2 ppm-nél, és a 16a- $\mathrm{H}_{2}$ multiplettjei 3,6 és 3,8 ppm-nél. A ${ }^{13} \mathrm{C}-\mathrm{NMR}$ spektrumban a C-17 és a C-16a jelei körülbelül 78 és 80 ppm kémiai eltolódásnál jelentek meg, ebből arra következtethettünk, hogy a C-17 egy $N$-atom, míg a C-16a egy szomszédos $O$-atom mellett helyezkedik el. A 137-es és a 138-as izoxazolidinek egymással diasztereoizomer viszonyban állnak. Az 138-as izomer protonspektrumában a 17-H dublettje jellemzően magasabb kémiai eltolódásnál (3,8ppm) mutatkozott, mint a megfelelő diasztereomere (137) esetén. A ${ }^{13} \mathrm{C}-\mathrm{NMR}$ spektrumban pedig a C-17 jele alacsonyabb kémiai eltolódásnál jelentkezett (70 ppm). Az $N$-metil-izoxazolidin (139) ${ }^{1} \mathrm{H}-\mathrm{NMR}$ felvételén jól elkülöníthető a 17-H jele 3,4 ppm-nél, és a 16-H jele 3,2 ppmnél, míg a 16a- $\mathrm{H}_{2}$ dublettje és triplettje 3,6 ppm-nél és 4,1 ppm-nél látható (39. ábra). Az izoxazolidinek (137-139) sztereokémiáját NOE-felvételekkel bizonyítottuk.

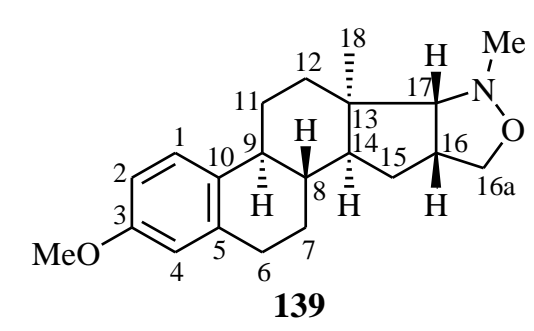

aromás protonok

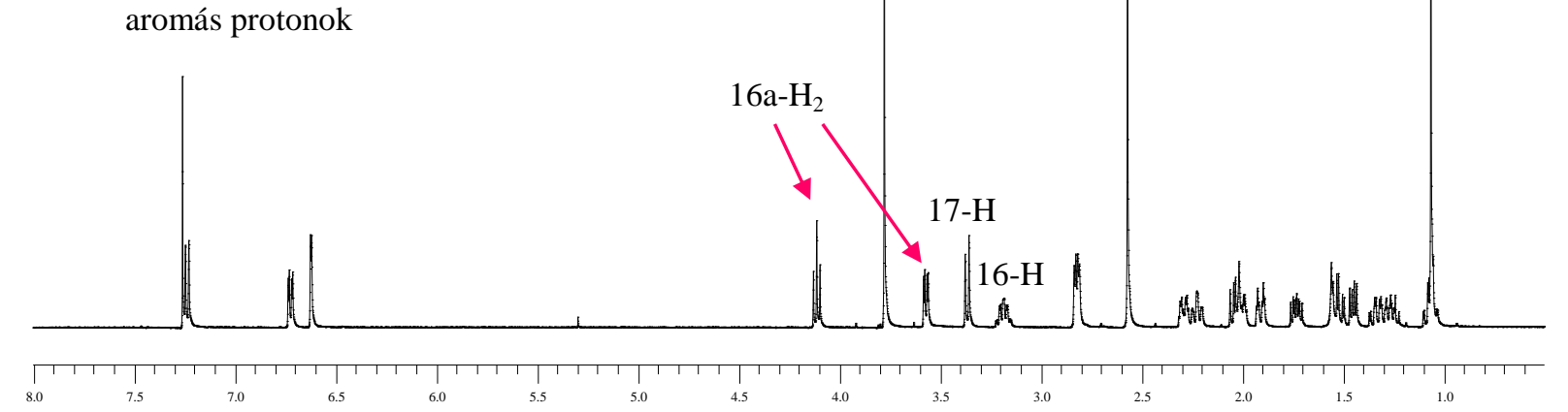

39. ábra: A 139-es diasztereomer ${ }^{1} \mathrm{H}-\mathrm{NMR}$ spektruma 


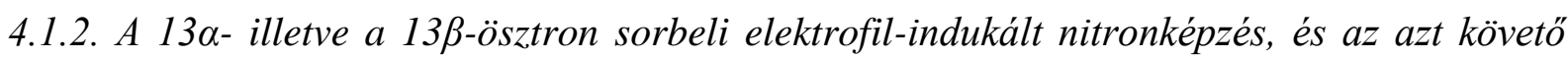

\section{1,3-dipoláris cikloaddíciók}

Munkánk folytatásában a $13 \alpha$ - és a $13 \beta$-ösztron sorbeli oximokból $(\mathbf{6 7}, \mathbf{1 3 5})$ elektrofilindukált gyürüzárási reakciókkal terveztünk nitron dipólusokat $(\mathbf{1 4 2}, 143)$ előállítani (40. ábra). ${ }^{103}$ Elektrofil reagensként $N$-brómszukcinimidet (NBS), $N$-jódszukcinimidet (NIS), vagy jódot alkalmaztunk, a cikloaddíciókat diklórmetános közegben végeztük. Az előállított gyürüs nitron dipólusokat $(\mathbf{1 4 2}, \mathbf{1 4 3}) \mathrm{C}=\mathrm{C}$ dipolarofillel $(N$-fenilmaleimid, NFM) reagáltattuk. $\mathrm{Az}$ 1,3-dipoláris cikloaddíciós reakciók 2 óra alatt (50 ${ }^{\circ} \mathrm{C}$-on) lejátszódtak, oldószerként toluolt alkalmaztunk. Mind a 13 $\alpha$-, mind a $13 \beta$-ösztron sorban a szintézisek sztereoszelektívnek bizonyultak, 16-brómmetil- (145a, 146a) illetve 16-jódmetil-izomert (145b, 146b) szolgáltatva.
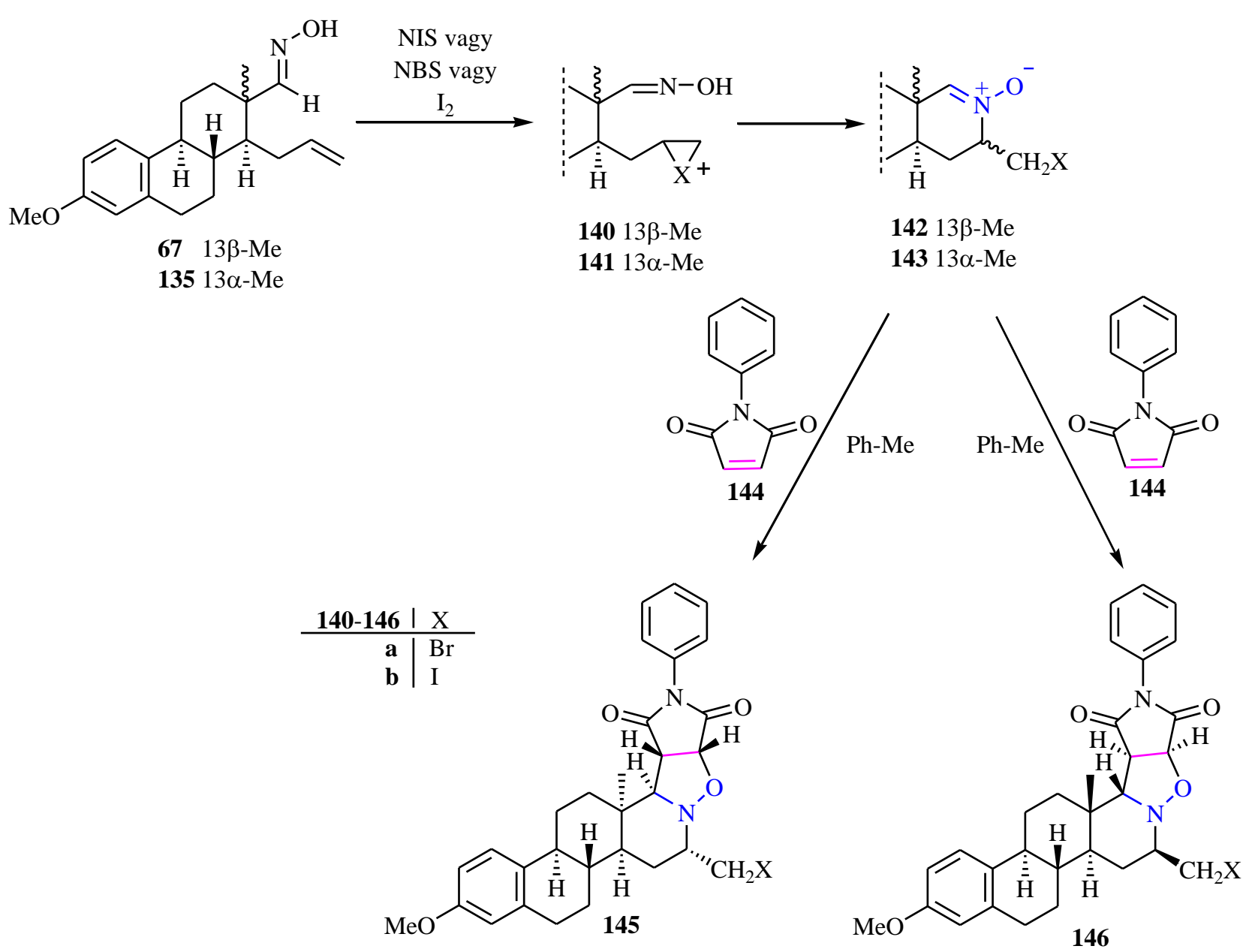

40. ábra: Elektrofil-indukált nitronképzés, majd azt követő 1,3-dipoláris cikloaddíció 
A újonnan szintetizált D-homoösztronok $(\mathbf{1 4 5}, \mathbf{1 4 6})$ szerkezetét 1D- illetve 2D-NMRspektroszkópiás felvételekkel bizonyítottuk. A 145b jelü vegyület ${ }^{1} \mathrm{H}-\mathrm{NMR}$-spektrumát mutatja a 41. ábra. Az aromás tartományban található nyolc proton tükrözi az NFM beépülését a molekulába. Jól látszik a 16a- $\mathrm{H}_{2}$ triplettje és multiplettje 3,3 ppm és 3,6 ppm kémiai eltolódásnál. A 17a-H dublettje 3,4 ppm-nél jelenik meg. A 4'-H trippletje alacsonyabb kémiai eltolódásnál (4,3 ppm) jelentkezik, mint a 3'-H dublettje (5,0 ppm). Az új sztereogén centrumok konfigurációinak meghatározásában a 2D-NMR segítette a munkánkat (COSY, NOESY és a HSQC). A 146a és a 146b NOESY-spektrumainak elemzéséből kitünt, hogy a 3'-H multiplettje keresztcsúcsot ad a 16-H, és a 4'-H jeleivel, ugyanekkor a 17a-H pedig az anguláris metilcsoporttal. Ez bizonyítja a 16-halometilcsoport ekvatoriális térhelyzetét, a 17a-H $\beta$ - és a 3'-H és a 4'-H $\alpha$-térállását. A 145-ös és a 146-os cikloadduktumokat összehasonlítva megfigyelhető, hogy a 13 $\alpha$-ösztron származékok (145a, b) szubsztituensei a 13ß-ösztron származékokhoz (146a, b) képest ellentétes térállásúak; a 16halometilcsoport $\alpha$-, a 3'-H és a 4'-H $\beta$-térállású (41. ábra).

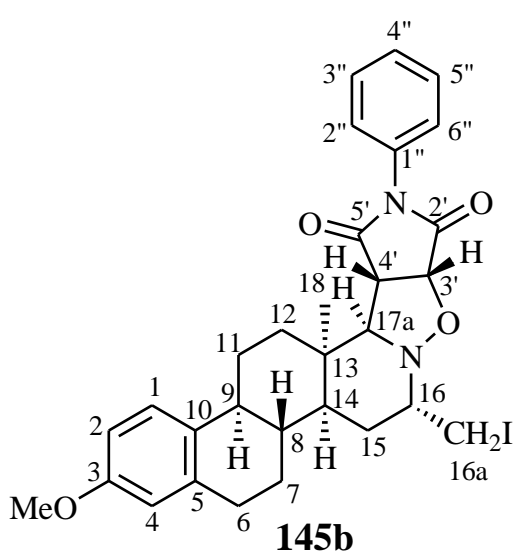

$18-\mathrm{CH}_{3}$

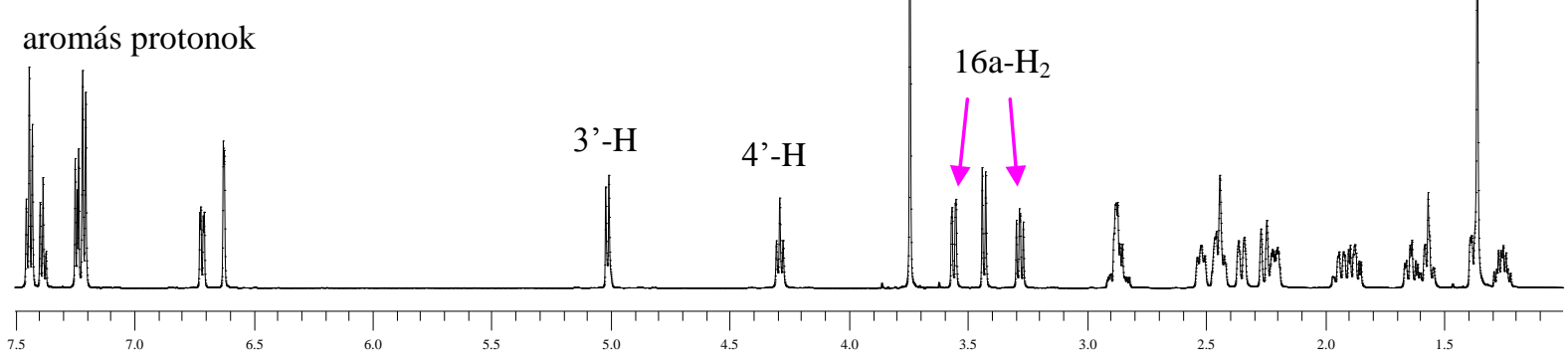

41. ábra: A 145b jelü vegyület ${ }^{1} \mathrm{H}-\mathrm{NMR}$-spektruma 
Az újonnan elöállított 145a jelü aza-D-homoösztron szerkezetét röntgenkrisztallográfiával is igazoltuk (42. ábra). A 42. ábrán jól látható, hogy a molekula C(ciklohexán) és D-gyürüje (piperidin) szék konformációjú. Az $\alpha$-helyzetü 16-brómmetilszubsztituens ekvatoriális térállású, a maleimid-rész pedig cisz-helyzetben anellálódott az izoxazolidin-gyürühöz.

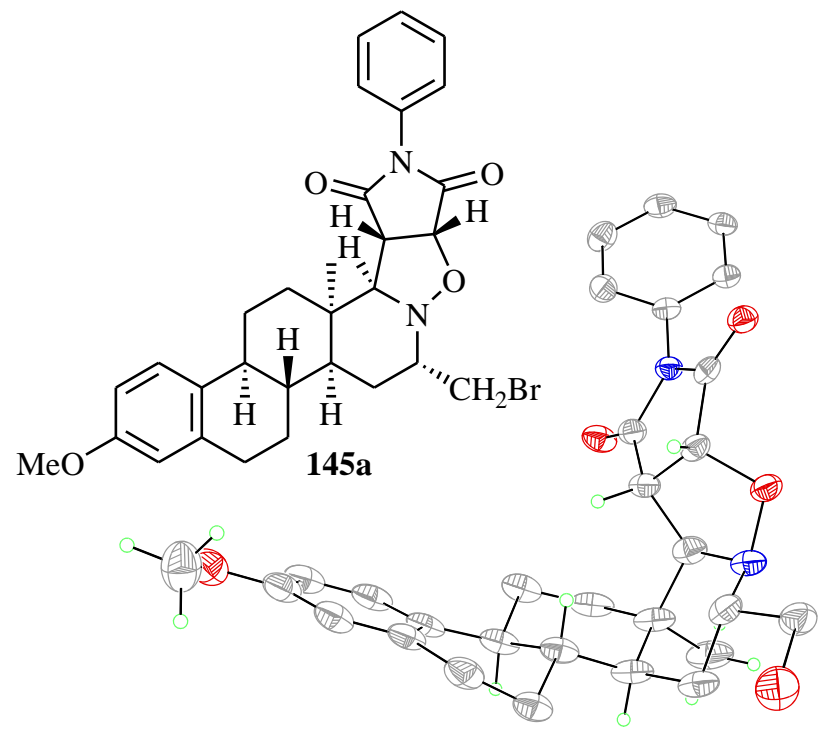

42. ábra: A 145a jelü aza-D-homoösztron röntgendiffrakcióval kapott szerkezete

Amennyiben az elektrofil-indukált nitronképzési reakciókat nem diklórmetánban, hanem acetonitrilben végeztük, csapadékkiválást tapasztaltunk. Az irodalmi előzményekben ismertetett kutatás alapján (lásd 21. oldal, 18. ábra) feltételezhető, hogy az alkalmazott reakciókörülmények között az oxim (67) ambidens nukleofilként viselkedett (43. ábra). Az Eoxim (67) esetén a $N$-atom, míg $Z$-oxim (67) esetén az $O$-atom intézhet nukleofil támadást a halónium-ionra. Az $O$-alkilezéssel képződött oxazepin származék (147), mint $\mathrm{C}=\mathrm{N}$ dipolarofil reakcióba léphet az $N$-alkilezéssel kapott gyürüs nitron (142a) 1,3-dipólussal, így kialakulhat egy nem szimmetrikus szteroid dimer (148). A dimerképződés reverzibilis jellegére utal, hogy az acetonitril bepárlásával, majd az NFM (144) hozzáadásával a várt cikloadduktumhoz (146a) jutottunk. A dimerből (148) valószínüleg gyürűs nitron (142a) és oxazepin (147) képződött. A kinetikailag kontrollált termék (147) egy egyensúly folyamán a termodinamikailag kontrollált termékké (142a) alakult. Megfigyeltük, hogy diklórmetános közegben is megjelent a dimer (148), azonban diklórmetánban való jó oldékonysága miatt 
nem vált ki az oldatból. Megállapítottuk továbbá, hogy a forralás elősegíti a dimer (148) gyors visszaalakulását gyürüs nitronná (142a).

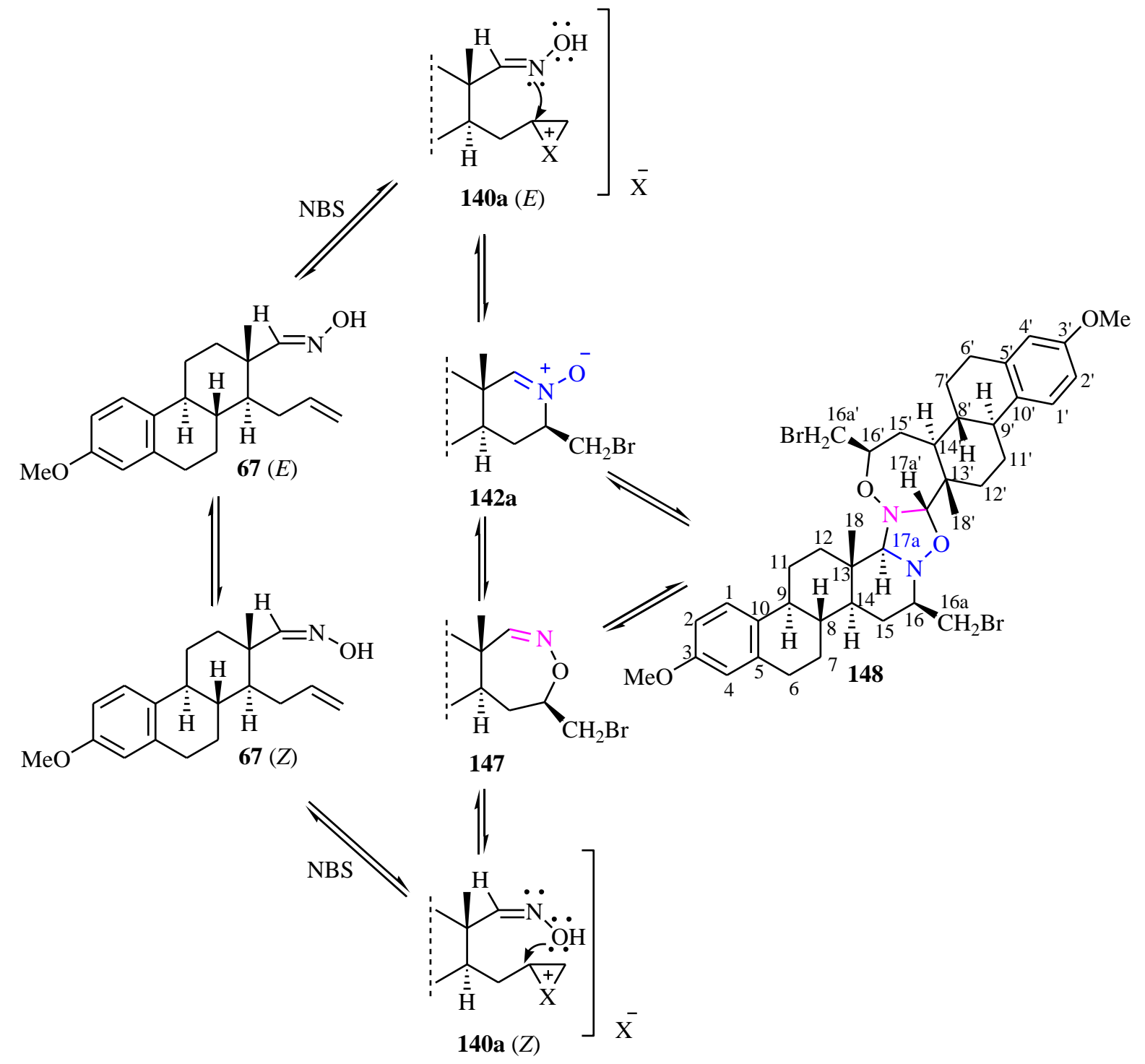

43. ábra: A dimer (148) képződésének feltételezett mechanizmusa

A dimer (148) szerkezetét ${ }^{1} \mathrm{H}-\mathrm{NMR}$ (44. ábra) és ${ }^{13} \mathrm{C}$-NMR spektrumokkal igazoltuk, amelyeken azonnal feltűnik, hogy a jelek „megduplázódtak”. A 44. ábrán jól látható, hogy a középső tartományban megjelenik két szingulett egységnyi intenzitással. A jelek alakja és kémiai eltolódása a dimer (148) 17a-H és 17a'-H-jának tulajdonítható. A 2,9 ppm és 3,8ppm közötti tartományban 12 proton jele látható, amelyek a 16a- $\mathrm{H}_{2}$, a 16a'- $\mathrm{H}_{2}$, a 16-H, a 16'- $\mathrm{H}$, a $3-\mathrm{OCH}_{3}$ és a 3'- $\mathrm{OCH}_{3}$ jelei. A dimer (148) 16- $\mathrm{H}$ jele 2,9 ppm, amíg a 16 ' $-\mathrm{H}$ jele 3,8 ppm 
kémiai eltolódásnál jelentkezik. Ez arra utal, hogy a 16-H egy $\mathrm{N}$-atomhoz, és a $16^{\prime}-\mathrm{H}$ egy $O$ atomhoz kapcsolódik.
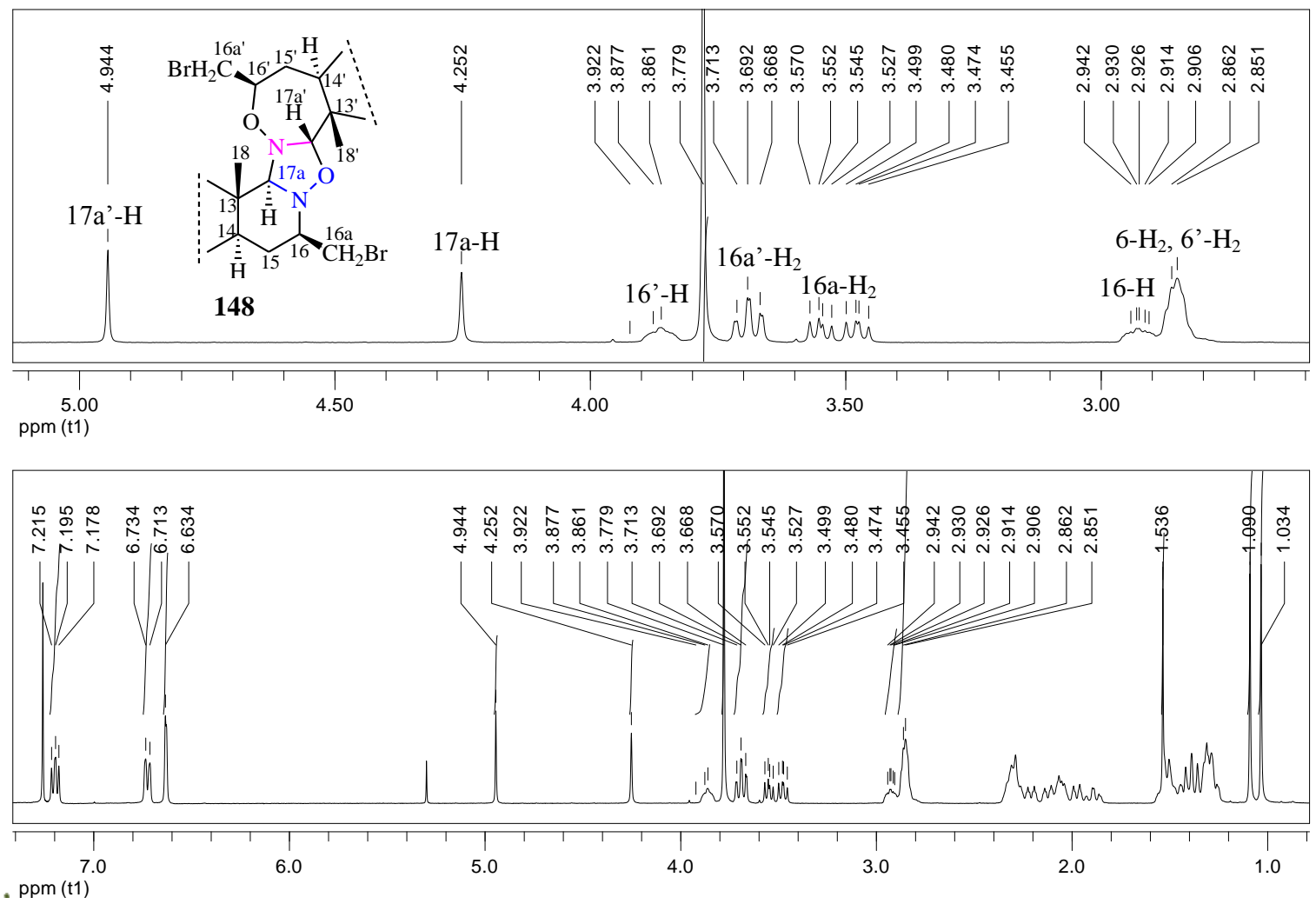

44. A 148-as jelü vegyület ${ }^{1} \mathrm{H}-\mathrm{NMR}$ spektruma és annak kiemelt részlete

Kutatómunkánkat a gyürüs nitron-dipólusok (142, 150) fenilizocianát $\mathrm{C}=\mathrm{N}$ dipolarofilekkel $(\mathbf{5 2}, \mathbf{1 5 1}, \mathbf{1 5 2})$ való cikloaddícióival folytattuk (45. ábra). ${ }^{104}$ A korábbi szintéziseinkhez hasonlóan az oximok $(67,149)$ ciklizációját elektrofil reagensekkel (NIS, NBS) hajtottuk végre. ${ }^{103,104}$ A kiindulási oximok $(67,149)$ átalakítása után az oldószert bepároltuk. A maradékot toluolban oldottuk, és 1 ekvivalens fenilizocianát $(\mathbf{5 2}, \mathbf{1 5 1}, \mathbf{1 5 2})$ alkalmazásával az 1. táblázatban feltüntetett ideig forraltunk. Ilyen körülmények között kiváló hozammal, kemoszelektíven nyertük a kondenzált vázas oxadiazolidinon származékokat (153-158). Az irodalmi elözményekhez képest ${ }^{54}$ magasabb hozammal, rövidebb reakcióidő alatt sikerült a céltermékeket (153-158) előállítani. Melléktermékek képződését nem tapasztaltuk. Minden esetben az a régioizomer képződött, amelynél a dipolarofil $N$-atomja a szteránváz 17a-szénatomjához kapcsolódott. A reakciósebességben eltérések mutatkoztak. Az elektronküldő $(-\mathrm{I}<+\mathrm{M})$ csoporttal rendelkező 4-metoxi-fenilizocianát (151) alkalmazása 
során tapasztaltuk a legrövidebb reakcióidőt, ezt a kettős természetü 4-klór-származékkal (152, -I > +M) végrehajtott 1,3-dipoláris cikloaddíciók követték, majd a leghosszabb reakcióidőt a szubsztituálatlan fenilizocianát (52) esetében figyeltük meg. Összehasonlítottuk a cikloaddíciók sztereo- és kemoszelektivitását hagyományos melegítés és mikrohullámú besugárzás mellett. Az utóbbi módszerrel $100{ }^{\circ} \mathrm{C}$-on, 1 perc alatt, sztereo- és kemoszelektíven nyertïk a kívánt oxadiazolidinon származékokat (153-158). A hagyományos melegítéshez képest a reakcióidő jelentősen csökkent, és a fenilizocianát $(\mathbf{5 2}, \mathbf{1 5 1}, \mathbf{1 5 2})$ szubsztituenseinek a reakciókörülményekre gyakorolt hatása nem volt megfigyelhető.<smiles>[R]Oc1ccc2c(c1)CC[C@@H]1[C@@H]2CC[C@](C)(C=O)[C@H]1CC=C</smiles>

65,66<smiles>[R20]c1ccc2c(c1)CC[C@@H]1[C@@H]2CC[C@](C)(/C=N/O)[C@H]1CC=C</smiles>

67, 149
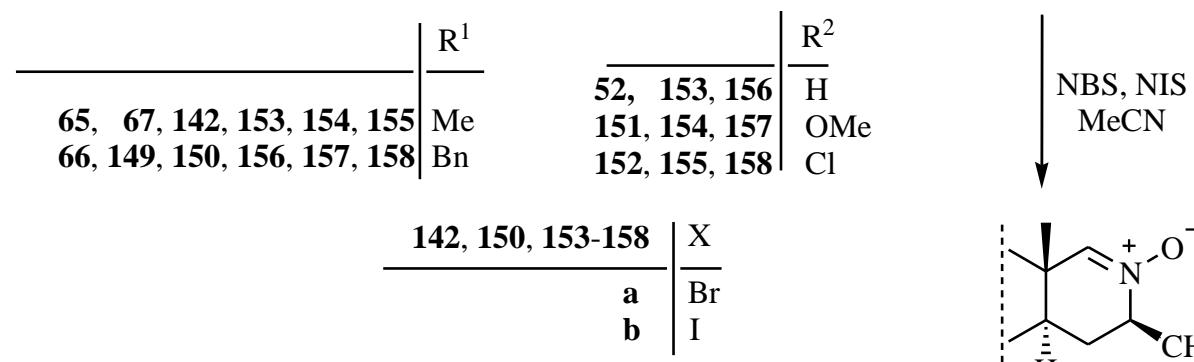<smiles>[X]CC1CC([Y])C(C)(C)C[N+]1[O-]</smiles><smiles>[Y]C[C@H]1C[C@H]2[C@@H]3CCc4cc(OC)ccc4[C@H]3CC[C@]2(C)[C@@]2(C)N(c3ccc([R4])cc3)C(=O)ON12</smiles>

153-155<smiles>[112In][131In]</smiles><smiles>[R4]c1ccc(N=O)cc1</smiles><smiles>[Y]C[C@H]1C[C@H]2[C@@H]3CCc4cc(OCc5ccccc5)ccc4[C@H]3CC[C@]2(C)[C@]2(C)N(c3ccc([R2])cc3)C(=O)ON12</smiles>

45. ábra: A nitron-dipólusok (142, 150) 1,3-dipoláris cikloaddíciója fenilizocianátokkal (52, $151,152)$ 


\begin{tabular}{|c|c|c|c|c|c|}
$\begin{array}{c}\text { Kiindulási } \\
\text { oxim }\end{array}$ & $\begin{array}{c}\text { Elektrofil } \\
\text { reagens }\end{array}$ & $\begin{array}{c}\text { Aromás } \\
\text { szubsztituens }\end{array}$ & $\begin{array}{c}\text { Reakcióidő } \\
(\mathbf{h})\end{array}$ & $\begin{array}{c}\text { Hozam } \\
(\%)^{\mathbf{a}}\end{array}$ & Termék \\
\hline $\mathbf{6 7}$ & NBS & $\mathrm{H}$ & 3 & $89(93)$ & $\mathbf{1 5 3 a}$ \\
\hline $\mathbf{6 7}$ & NIS & $\mathrm{H}$ & 3 & $84(90)$ & $\mathbf{1 5 3 b}$ \\
\hline $\mathbf{6 7}$ & NBS & OMe & 0.5 & $92(93)$ & $\mathbf{1 5 4 a}$ \\
\hline $\mathbf{6 7}$ & NIS & OMe & 0.5 & $95(96)$ & $\mathbf{1 5 4 b}$ \\
\hline $\mathbf{6 7}$ & NBS & Cl & 2 & $96(96)$ & $\mathbf{1 5 5 a}$ \\
\hline $\mathbf{6 7}$ & NIS & $\mathrm{Cl}$ & 2 & $90(93)$ & $\mathbf{1 5 5 b}$ \\
\hline $\mathbf{1 4 9}$ & NBS & $\mathrm{H}$ & 3 & $89(93)$ & $\mathbf{1 5 6 a}$ \\
\hline $\mathbf{1 4 9}$ & NIS & $\mathrm{H}$ & 3 & $85(89)$ & $\mathbf{1 5 6 b}$ \\
\hline $\mathbf{1 4 9}$ & NBS & OMe & 0.5 & $95(96)$ & $\mathbf{1 5 7 a}$ \\
\hline $\mathbf{1 4 9}$ & NIS & OMe & 0.5 & $97(98)$ & $\mathbf{1 5 7 b}$ \\
\hline $\mathbf{1 4 9}$ & NBS & $\mathrm{Cl}$ & 2 & $90(92)$ & $\mathbf{1 5 8 a}$ \\
\hline $\mathbf{1 4 9}$ & NIS & $\mathrm{Cl}$ & 2 & $91(93)$ & $\mathbf{1 5 8 b}$ \\
\hline
\end{tabular}

a: A zárójelben feltüntetett adatok az 1 percig tartó, 100 C-os mikrohullámú besugárzás során kapott hozamok

1. táblázat: A képződő oxadiazolidinonok (153-158) hozamai hagyományos és mikrohullámú melegítés mellett

Az 1,3-dipoláris cikloaddíció során nyert oxadiazolidinonok (153-158) szerkezetét NMR-spektroszkópiai módszerekkel igazoltuk. A 46. ábra a 153b jelü vegyület ${ }^{1} \mathrm{H}-\mathrm{NMR}$ felvételét mutatja. A D-homoösztron származék (153b) 16-os protonjának multiplettje 3,1 ppm, 16a- $\mathrm{H}_{2}$ multiplettje 3,5 ppm, a 17a-H szingulettje pedig 5,2 ppm kémiai eltolódásnál jelentkezik. Az ${ }^{1} \mathrm{H}-,{ }^{13} \mathrm{C}-\mathrm{NMR}$, COSY, NOESY, HSQC, HMBC technikák felhasználásával határoztuk meg az oxadiazolidinonok (153-158) proton illetve szén jeleinek kémiai eltolódásait. A NOESY-spektrumok elemzéséből megállapítottuk, hogy a vegyületek (153158) $16-\mathrm{CH}_{2} \mathrm{X}$ és $17 \mathrm{a}-\mathrm{H}$ jelei keresztcsúcsot adnak az anguláris metilcsoport $\left(18-\mathrm{CH}_{3}\right)$ jelével. Ebből következtettünk a 16-os szubsztituens és a 17a-H azonos, $\beta$-térállására. 


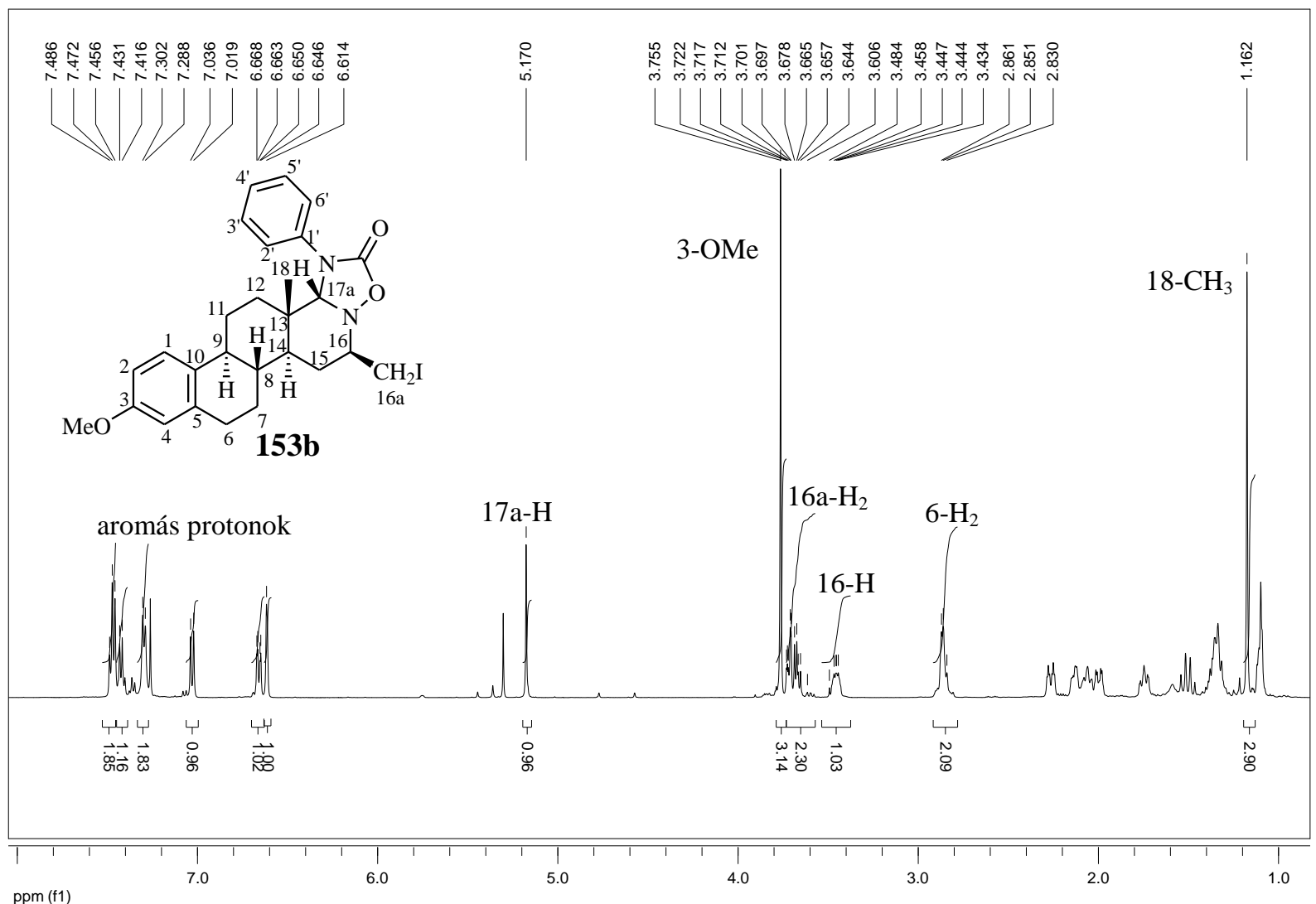

46. ábra: A 153b jelű oxadiazolidinon ${ }^{1} \mathrm{H}-\mathrm{NMR}$ spektruma

A vegyületek (153-158) C-2' és C-6' jelei a ${ }^{13}$ C-NMR spektrumból hiányoznak. Ennek a jelenségnek feltehetően az a magyarázata, hogy az oxadiazolidinon gyürün lévő fenilcsoport szabadon rotál, és ezek a molekuláris mozgások sokkal gyorsabbak, mint az NMR időskálája, tehát egy dinamikus effektus lép fel. ${ }^{105,106}$ Ennek eredményeként a C-2' és a C-6' jelei kiszélesednek és beleolvadnak a zajba. A szobahőmérséklethez képest megnövelt hőmérséklet nagymértékben meghaladta a koaleszcencia (egyesülési) hőmérsékletet, így a két szénatom jele 128,0 ppm-nél megjelent. Ahhoz, hogy a vegyületeink (153-158) C-2' és C-6' jelei láthatóvá váljanak, felvettük az egyik oxadiazolidinon származékok (153a) NMRspektrumát $55{ }^{\circ} \mathrm{C}$-on, $\mathrm{CDCl}_{3}$-ban. A $\mathrm{HSQC}$-felvételen látható keresztcsúcsokból következtettünk a C-2' és C-6' jelek kémiai eltolódására (128 ppm). Molekuláris modellezéssel igazoltuk a D-homoösztron származékok (153-158) legstabilabb szerkezetét, figyelembe véve a 16-os és a 17a-C-atom összes lehetséges konfigurációját. A konformáció szabályszerűségét egy sztochasztikus kísérlettel bizonyítottuk. Ehhez a Merck Molecular Force Field (MMFF94) program nyújtott segítséget. Az így kapott alacsony energiájú konformációkat minimalizáltuk a HF/6-311G-t ab initio szintre állítva. Tapasztalataink szerint 
a termékek (153-158) egy stabil konformációt vettek fel, szerkezetüket a 45. ábrán tüntettük fel. Az oxadiazolidinon származékok (153-158) további szerkezetbizonyítását MALDI TOF (deszorpciós/ionizációs) tömegspektrometria segítségével, $\mathrm{C}_{70}$-es fullerén mátrixot alkalmazva, pozitív üzemmódban határoztuk meg. ${ }^{107-109}$ A tömegspektrometriás analízis során fragmensionok keletkeztek a $\mathrm{CO}_{2}$, és/vagy a fenilcsoport (vagy a szubsztituált fenilcsoport), és/vagy a megfelelő halogénatom lehasadásával.

Az újonnan előállított heterociklusos D-homoszteroidok (153-158) olyan szerkezeti sajátságokkal rendelkeznek, amelyek indokolttá teszik a vegyületek gyógyszerhatástani tesztelését potenciális antitumor aktivitás szempontjából. A D-homo jelleg ugyanis antiproliferatív hatást kölcsönözhet a vegyületnek, csökkent ösztrogén aktivitás mellett, ugyanakkor az oxadiazolidin heterociklus jelenléte, a tubulin polimerizációjára gyakorolt hatása miatt, növelheti az antitumor potenciált. Halogén jelenléte a szteroidban szintén előnyös lehet, antihormonális tulajdonság előidézése következtében. Mindezek alapján megvizsgáltuk az általunk előállított oxadiazolidinonok (153-158) antiproliferatív tulajdonságait négy humán adherens (Hela - méhnyakrák karcinóma, MCF-7 emlőkarcinóma, A2780 - petefészek karcinóma, A431 - bőrlaphám karcinóma), és egy intakt sejtvonalon (HFF - humán fibroblaszt) MTT-módszer segítségével. A 2. táblázat összefoglalja a különböző sejtvonalakon mért $\mathrm{IC}_{50}$ értékeket a ciszplatinhoz, mint referenciavegyülethez képest. A D-homoösztronok (153-158) egymástól a C-3, a C-16 és a fenilizocianát (52, 151, 152) szubsztituenseinek minőségében különböznek. Megfigyeltük, hogy az A-gyürün lévő étercsoport módosításával az antiproliferatív hatás mértéke befolyásolható. A benzil-éter-funkcióval rendelkező származékok (156a, b és 158a, b) sok esetben kedvezőbb antitumor hatással bírtak 3-metoxi-megfelelőikhez (153a, b és 155a, b) képest. A 2. táblázatból kitünik, hogy a 16-os pozícióban lévő $\mathrm{CH}_{2} \mathrm{X}$ szubsztituens minősége nagymértékben befolyásolta az antiproliferatív aktivitást. A jódszármazékok (153b, 155b, 156b, 158b) jobban gátolták a sejtosztódást a brómszármazékokhoz (153a, 155a, 156a, 158a) viszonyítva. A fenilizocianát $(\mathbf{5 2}, \mathbf{1 5 1}, \mathbf{1 5 2}) \mathrm{R}^{2}$-csoportjának változtatásával a vegyületek (153-158) rákellenes hatása is módosul. Azt tapasztaltuk, hogy a p-metoxi-származékok (154a, b és 157a, b) teljesen inaktívnak tekinthetők mindegyik sejtvonalon $\left(\mathrm{IC}_{50}>30 \mu \mathrm{M}\right)$. Az eredményekből azt a következtetést vontuk le, hogy a 3-as helyzetű benzil védőcsoport és a hattagú D-gyürü jelenléte, az oxadiazolidinon heterociklusnak a molekulába való beépítése, illetve a 16-os helyzetben lévő $\mathrm{CH}_{2} \mathrm{I}$ szubsztituens előnyös a tumorszelektív sejtosztódástgátló hatás szempontjából. 


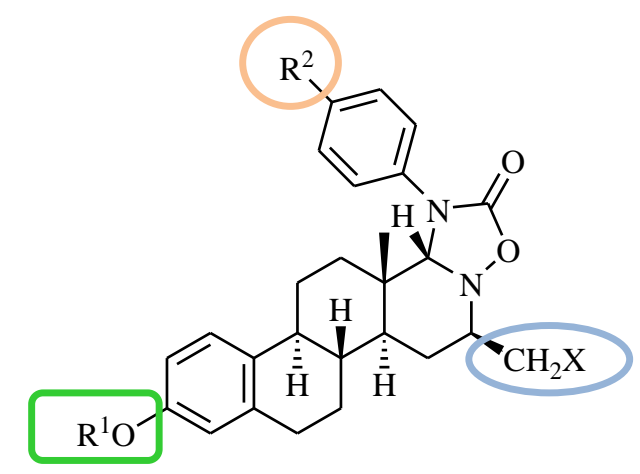

\begin{tabular}{|c|c|c|c|c|}
\hline \multirow{2}{*}{ 153a } & Hela & A431 & A2780 & MCF-7 \\
\cline { 2 - 5 } & 11,3 & $>30$ & 13,8 & 9,6 \\
\hline 153b & 6,7 & $>30$ & 6,3 & 10,5 \\
\hline 154a & $>30$ & $>30$ & $>30$ & $>30$ \\
\hline 154b & $>30$ & $>30$ & $>30$ & $>30$ \\
\hline 155a & 9,2 & $>30$ & 13,9 & 7,6 \\
\hline 155b & 4,9 & $>30$ & 5,0 & 7,2 \\
\hline 156a & 5,5 & $>30$ & 3,2 & 5,7 \\
\hline 156b & 13,4 & $>30$ & 2,2 & 12,5 \\
\hline 157a & $>30$ & $>30$ & $>30$ & $>30$ \\
\hline 157b & $>30$ & $>30$ & $>30$ & $>30$ \\
\hline 158a & 12,5 & $>30$ & 5,5 & 8,4 \\
\hline 158b & 11,0 & $>30$ & 4,6 & 9,2 \\
\hline ciszplatin & 5,7 & 8,8 & 0,9 & 8,0 \\
\hline
\end{tabular}

a: 2-2 független méréssel, 5-5 párhuzamossal kapott értékek, a standard deviáció <15\% lila: jódszármazékok; sárga: 3-OMe; rózsaszín: leghatásosabb vegyület

2. táblázat: Az oxadiazolidinonok (153-158) antiproliferatív hatásai humán adherens tumorsejtvonalakon

A 16-jódmetil- $N$-fenil-3-benziloxi származék (156b) volt az egyik leghatékonyabb antitumor vegyület, különösen az A2780-as sejtvonalon $\left(\mathrm{IC}_{50}=2,2 \mu \mathrm{M}\right)$. Ahhoz, hogy összehasonlítsuk a tesztanyagunk (156b) tumorsejteken mért $\mathrm{IC}_{50}$-értékeit az intakt 
sejtvonalon (HFF - human fibroblaszt) mért sejtosztódás gátlással, a HFF sejteket az oxadiazolidinon származék (156b) 1 és $10 \mu \mathrm{M}$-os koncentrációjával kezeltük. A referenciavegyület (ciszplatin) és a szteroid (156b) antiproliferatív hatását gátlás \%-ban adtuk meg (3. táblázat). A 3. táblázatból kitünik, hogy a ciszplatinhoz képest a vegyület (156b) nem mutatott jelentős sejtosztódás gátló hatást. Az eredmények szerint a $\mathbf{1 5 6 b}$ tumorszelektívnek tekinthetö.

\begin{tabular}{|c|c|c|c|}
\hline \multirow{2}{*}{} & \multicolumn{3}{|c|}{ Gátlás (\%) \pm SEM } \\
\cline { 2 - 4 } & $\mathbf{3}$ & HIF \\
\cline { 2 - 4 } & $\mathbf{1 5 6 b}$ & ciszplation & P-érték $^{\mathrm{a}}$ \\
\hline $\mathbf{1 0} \boldsymbol{\mu M}$ & $0,1 \pm 2,6$ & $1,9 \pm 1,8$ & NS \\
\hline
\end{tabular}

a: párosítatlan $t$-próbával számítottuk ki a kapott $P$-értékeket. NS: nem szignifikáns különbség

3. táblázat: A 156b jelü vegyület és a ciszplatin sejtosztódás gátló hatása HFF intakt sejtvonalon

A 156b jelü vegyület antiproliferatív hatásmechanizmusának megállapítása érdekében sejtciklus analízist végeztünk (47. ábra). 24 illetve 48 órás inkubációt követően a $\mathbf{1 5 6 b}$ jelü vegyület $3 \mu \mathrm{M}$ koncentrációjú oldatával kezelt A2780-as sejtekben az S-fázis szignifikáns csökkenését tapasztaltuk (47. ábra). Ugyanez megfigyelhető a $10 \mu \mathrm{M}$-os koncentrációnál is, továbbá azt tapasztaltuk, hogy a sejtek G1-fázisban szaporodtak fel. 48 órás expozíciót követően a sejteloszlásban mért változás markánsabbnak bizonyult. Ebből következtettünk a sejtciklus G1-S blokádjára. 

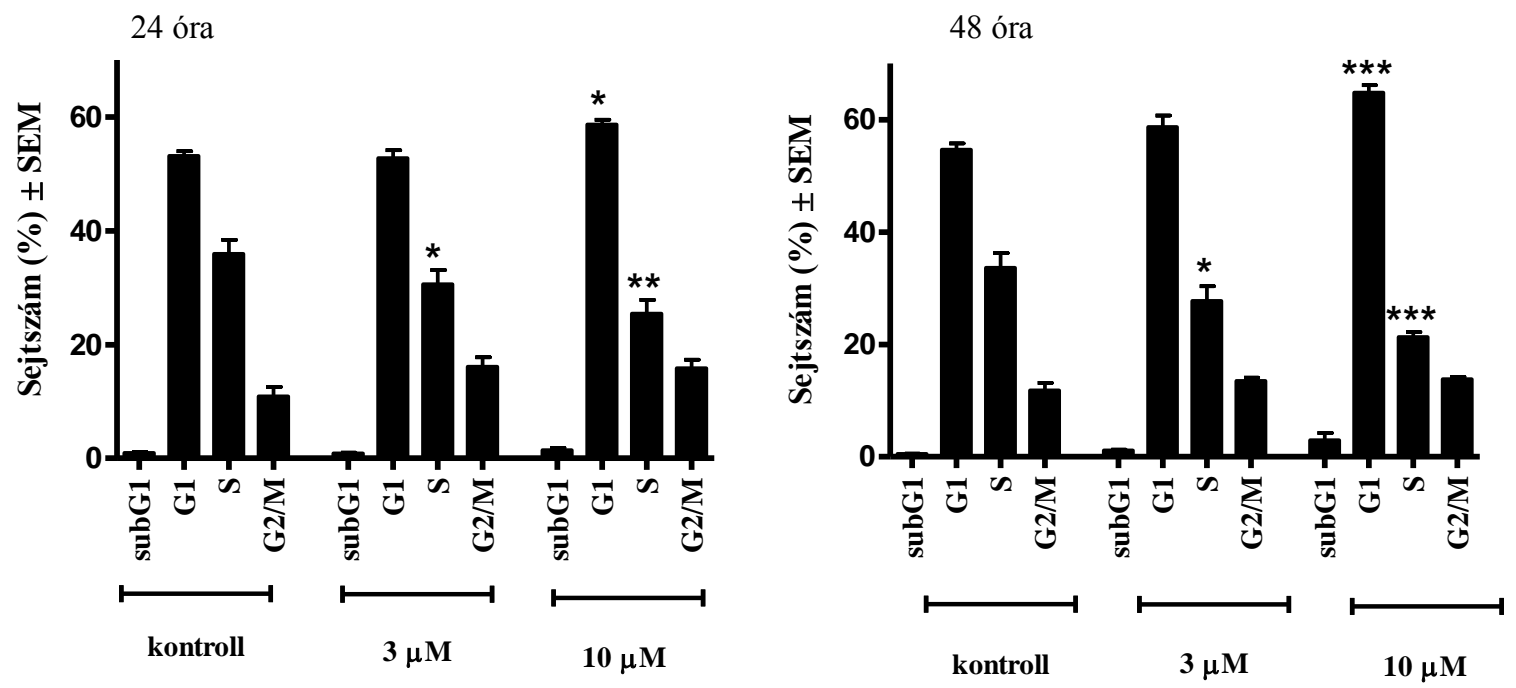

47. ábra: A 156b jelű vegyület A2780-as sejtek eloszlására gyakorolt hatása (24 illetve 48 órás inkubációs idő után) $*$ - $p<0,05, * *-p<0,01, * * *$ - $p<0,001$, a kontroll sejtekhez viszonyítva 


\subsubsection{Az ösztron-azid dipólusok elöállitása és CuAAC reakcióik}

Kísérleti munkánk folytatásaként azid dipólusokat állítottunk elő az ösztron sorban. Az ösztron-3-benzil-étert (8) többlépéses reakciósor eredményeként azidoalkoholokká $(\mathbf{1 6 6}, \mathbf{1 6 7})$ alakítottunk. Első lépésben az ösztron-3-benzil-éterét (8) réz-bromid felhasználásával, toluolos-metanolos közegben brómoztuk (48. ábra). A brómhidrineket $(\mathbf{1 6 0}, \mathbf{1 6 1})$ a 159-es jelü vegyület nátrium-tetrahidrido-borátos redukciójával nyertuik. Az olefin (162) szintézisét a brómhidrinek (160, 161) cink-jégecetes átalakításával valósítottuk meg. Az alként (162) diklórmetán-metanolos közegben magnézium-monoperoxiftaláttal reagáltatva,

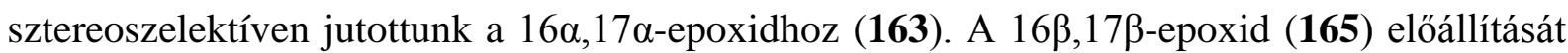
kétlépéses folyamatban valósítottuk meg. Elsőként a szteroid-olefint (162) NBS-del, dimetilszulfoxid-metanol oldószerelegyben brómhidrinné (164) alakítottuk, majd azt metanolban, $5 \%$-os $\mathrm{K}_{2} \mathrm{CO}_{3}$ oldattal forralva jutottunk a $16 \beta, 17 \beta$-epoxidhoz (165). Az epoxidok $(\mathbf{1 6 3}, \mathbf{1 6 5})$ gyürünyitásához 7 ekvivalens mennyiségü $\mathrm{NaN}_{3}$ nukleofil reagenst használtunk. Dimetilszulfoxid-jégecetes közegben (10:1), forralás mellett régioszelektíven nyertük a transz-16azido-17-alkoholokat $(\mathbf{1 6 6}, \mathbf{1 6 7})$. Ez utóbbi vegyületek szolgáltak kiindulási anyagként a CuAAC átalakításokhoz. 
<smiles>CC12CCC3c4ccc(OCc5ccccc5)cc4CC[C@H]3[C@@H]1CCC2=O</smiles>

$\mathrm{CuBr}_{2}$, forralás

$\mathrm{Ph}-\mathrm{Me}, \mathrm{MeOH}$<smiles>C1CCC1</smiles><smiles>CC1(I)C(=O)[C@H](F)C[C@H]1I</smiles>

159a,b
$\mathrm{NaBH}_{4}, \mathrm{CH}_{2} \mathrm{Cl}_{2}, \mathrm{MeOH}$<smiles></smiles>

$\mathbf{1 6 0}=17 \alpha-\mathrm{OH} \quad \mathbf{1 6 0 a}, \mathbf{b}$ $161=17 \beta-O H \quad 161 a, b$<smiles>CC(=O)OCC1CC2OC2C1(C)I</smiles>

165
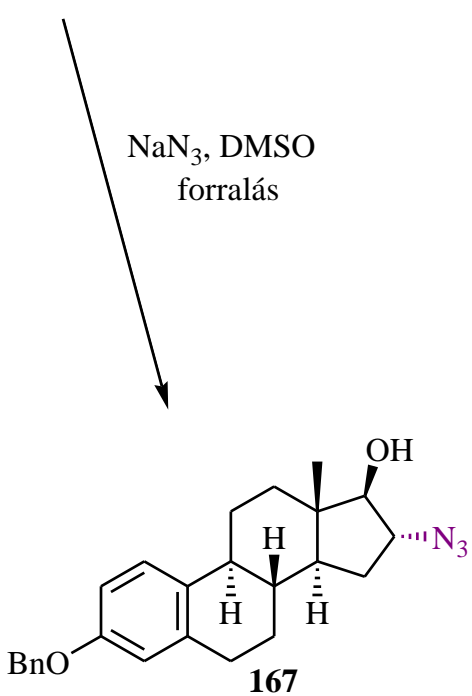

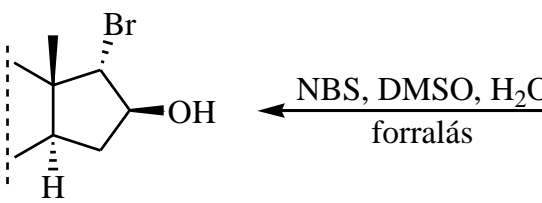

164<smiles>CC12C=CC[C@H](I)[C@H]1[IH]2</smiles>

162

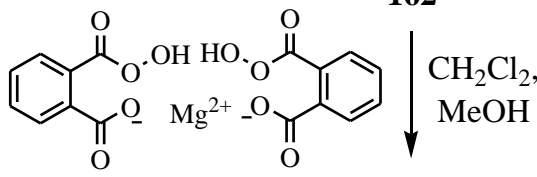

$\mathrm{NaN}_{3}$, DMSO forralás<smiles>C[C@]12CC[C@@H]3c4ccc(OCc5ccccc5)cc4CC[C@H]3[C@H]1C[C@@H](N)[C@H]2O</smiles>

48. ábra: A transz-16-azido-17-alkoholok $(\mathbf{1 6 6}, \mathbf{1 6 7})$ előállítása az epoxidok $(\mathbf{1 6 3}, \mathbf{1 6 5})$ gyürünyitásával

A $16 \beta$-azido-ösztron-3-benzil-éter-17 $\alpha$-olt (166) és a 16 $\alpha$-azido-ösztron-3-benzil-éter17 $\beta$-olt (167) monoszubsztituált acetilénekkel (168a-e) reagáltattuk (49. ábra). Az 1,3dipoláris cikloaddíciókat katalitikus mennyiségű (0,1 ekvivalens) $\mathrm{CuI}$ és $\mathrm{PPh}_{3}$ komplexáló ligandum (0,2 ekvivalens) segítségével, 3 ekvivalens mennyiségű $N, N$-diizopropil-etilamin (DIPEA) bázis jelenlétében hajtottunk végre. A reakciók 2 óra alatt végbementek. A szintézisek régioszelektíven szolgáltatták a 16-triazolil-17-hidroxiösztron-3-benzil-étereket (169a-e és 170a-e). A fenilacetilén aromás gyürüjén lévő szubsztituensek helyzete és 
minősége nem befolyásolta sem a reakciósebességet, sem a céltermékek (169a-e és 170a-e) hozamát (4. táblázat).

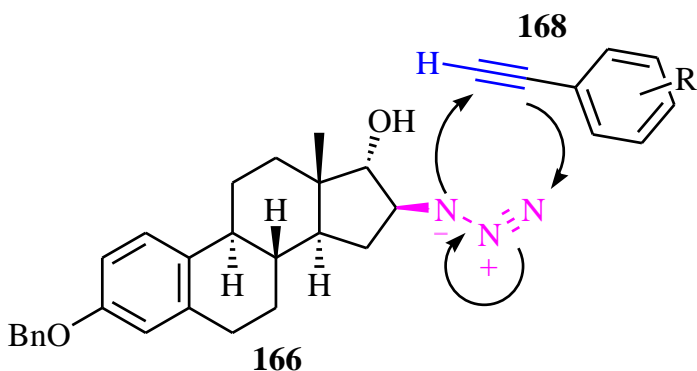

166

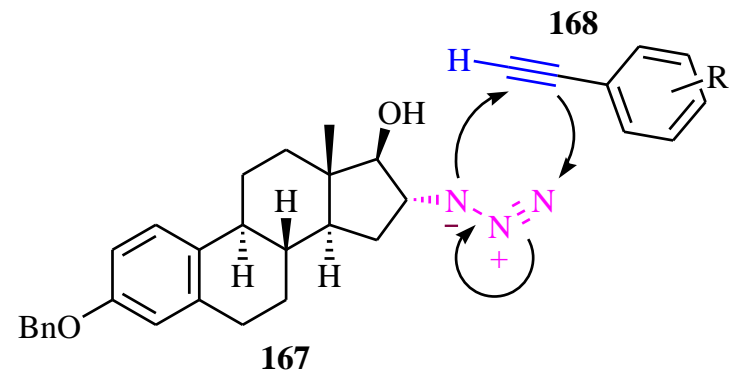

$\mathrm{CuI}, \mathrm{PPh}_{3}$, DIPEA

Ph-Me, forralás<smiles>[R]c1ccc(-c2cn([C@@H]3C[C@H]4[C@@H]5CCc6cc(OCc7ccccc7)ccc6[C@@H]5CC[C@]4(C)[C@H]3O)nn2)cc1</smiles>

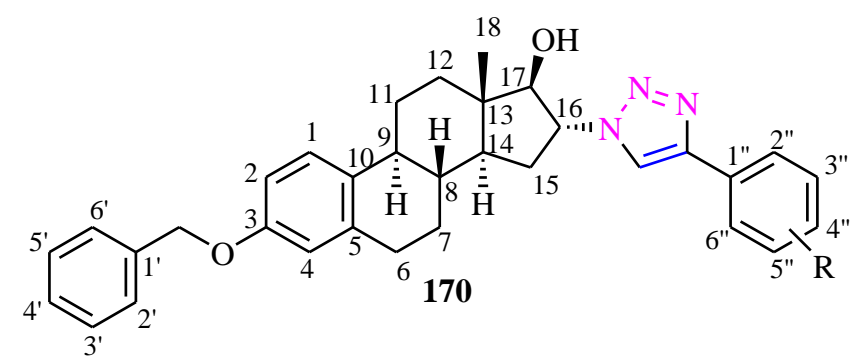

\begin{tabular}{|c|c|}
\hline $168,169,170$ & $\mathrm{R}$ \\
\hline $\mathbf{a}$ & $\mathrm{H}$ \\
\hline b & 3"-Me \\
\hline c & 4"-Me \\
\hline d & $4 "-\mathrm{CF}_{3}$ \\
\hline e & 4"-Et \\
\hline
\end{tabular}

49. ábra: A 16-triazolil-17-hidroxiösztron-3-benzil-éterek (169-170) szintézise réz(I)katalizált 1,3-dipoláris cikloaddícióval 


\begin{tabular}{|c|c|c|c|}
\hline Azid & Alkin & Termék & Hozam (\%) \\
\hline $\mathbf{1 6 6}$ & $\mathbf{1 6 8 a}$ & $\mathbf{1 6 9 a}$ & 85 \\
\hline $\mathbf{1 6 6}$ & $\mathbf{1 6 8 b}$ & $\mathbf{1 6 9 b}$ & 92 \\
\hline $\mathbf{1 6 6}$ & $\mathbf{1 6 8 c}$ & $\mathbf{1 6 9 c}$ & 93 \\
\hline $\mathbf{1 6 6}$ & $\mathbf{1 6 8 d}$ & $\mathbf{1 6 9 d}$ & 93 \\
\hline $\mathbf{1 6 6}$ & $\mathbf{1 6 8}$ & $\mathbf{1 6 9}$ & 89 \\
\hline $\mathbf{1 6 7}$ & $\mathbf{1 6 8}$ & $\mathbf{1 7 0 a}$ & 90 \\
\hline $\mathbf{1 6 7}$ & $\mathbf{1 6 8 b}$ & $\mathbf{1 7 0 b}$ & 92 \\
\hline $\mathbf{1 6 7}$ & $\mathbf{1 6 8 c}$ & $\mathbf{1 7 0 c}$ & 91 \\
\hline $\mathbf{1 6 7}$ & $\mathbf{1 6 8 d}$ & $\mathbf{1 7 0 d}$ & 92 \\
\hline $\mathbf{1 6 7}$ & $\mathbf{1 6 8 e}$ & $\mathbf{1 7 0 e}$ & 88 \\
\hline
\end{tabular}

4. táblázat: A CuAAC reakciók során képződött termékek (169a-e és 170a-e) hozamai

A célból, hogy a későbbi biológiai vizsgálatokhoz további származékokat nyerjünk, az azidoalkoholokat különböző átalakításoknak vetettük alá. A 166-os azidoalkohol Jonesoxidációja során 17-ketont (171) kaptunk, amely redukciója egy új cisz-azidoalkoholt (172) eredményezett (50. ábra).

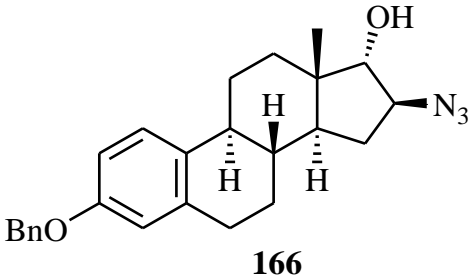

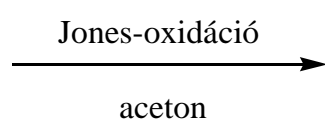<smiles>CC1(I)C(=O)C([NH-])C[C@H]1I</smiles>

171

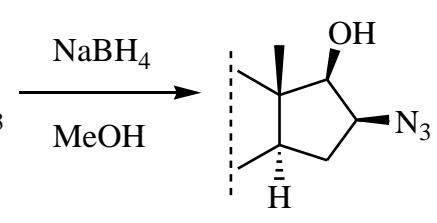

172

50. ábra: A 16ß-azido-3-benziloxiösztra-1,3,5(10)-trién-17 $\alpha$-ol (166) Jones-oxidációja, és az azidoketon (171) redukciója

Célunk volt annak vizsgálata is, hogy a biológiai aktivitáshoz szükséges-e a 17-es oxigén-funkció jelenléte, így kerülő úton megvalósítottuk annak eltávolítását is, a 17-dezoxi származék előállítása céljából. A szteroid-olefin (162) benzil-védőcsoportját katalitikus hidrogénezéssel, Pd/C katalizátort alkalmazva eltávolítottuk (51. ábra). A szteroid (162) etilacetátos oldatát 20 bar hidrogénnyomás alatt, 2 órán át kevertük. A reakció során a 
debenzilezés mellett a vegyület (162) kettős kötése is telítődött, így jutottunk a 17-dezoxi származékhoz (173).

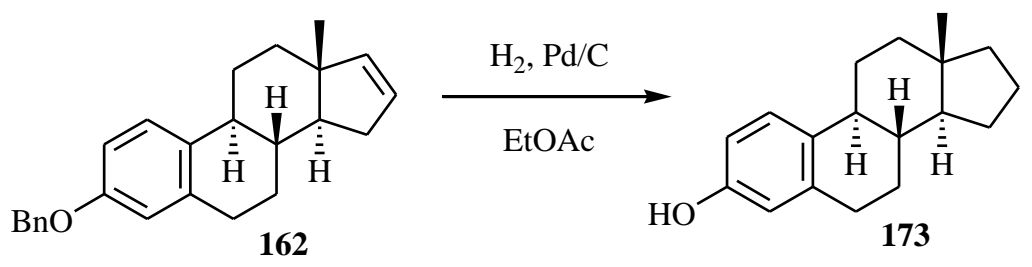

51. ábra: A 16-olefin (162) katalitikus hidrogénezése

Az előállított vegyületek szerkezetét ${ }^{1} \mathrm{H}-\mathrm{NMR}$ és ${ }^{13} \mathrm{C}-\mathrm{NMR}$ felvételekkel igazoltuk. A ${ }^{13} \mathrm{C}-\mathrm{NMR}$ spektrumban a transz-azidoalkoholok $(\mathbf{1 6 6}, \mathbf{1 6 7}) \mathrm{C}-16$ és C-17 jelei magasabb kémiai eltolódásnál (67 ppm és 87 ppm között) jelentkeznek, mint a nekik megfelelő epoxidoké (163, 165, 53 ppm és 66 ppm, 52. ábra). Az azidoalkoholok $(\mathbf{1 6 6}, 167)$ jeleinek magasabb kémiai eltolódása jelzi, hogy az epoxidok $(\mathbf{1 6 3}, \mathbf{1 6 5})$ gyürünyitása végbement, a 16-os és 17-es helyzetben kialakult a vicinális azidoalkohol-funkció. 


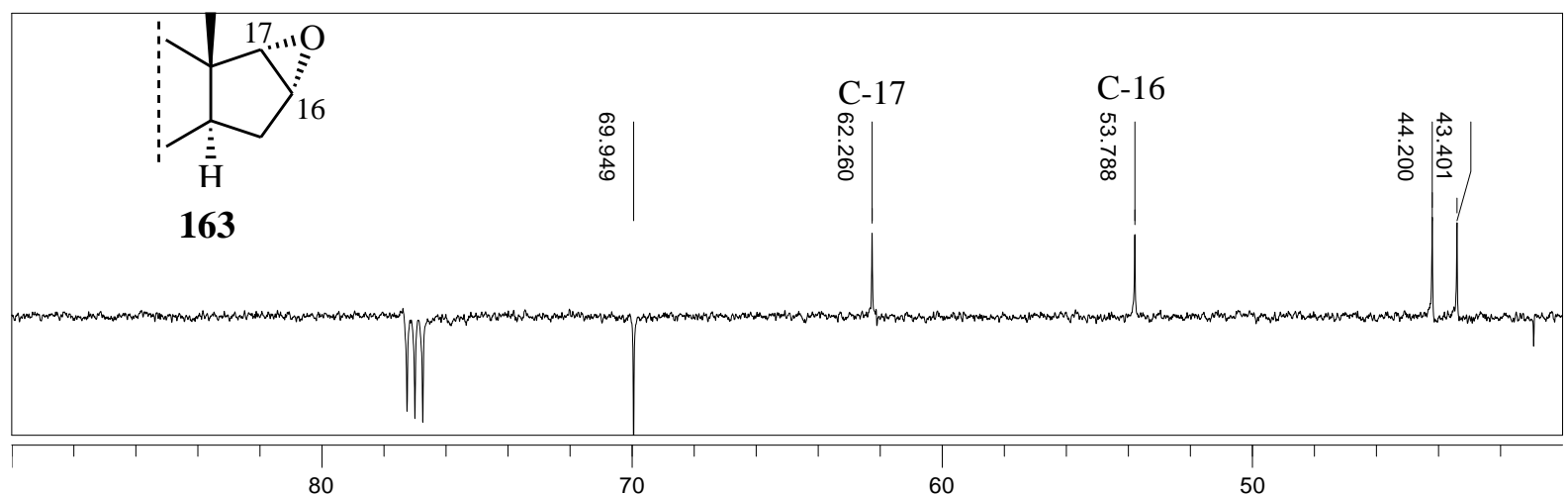

ppm (t1)

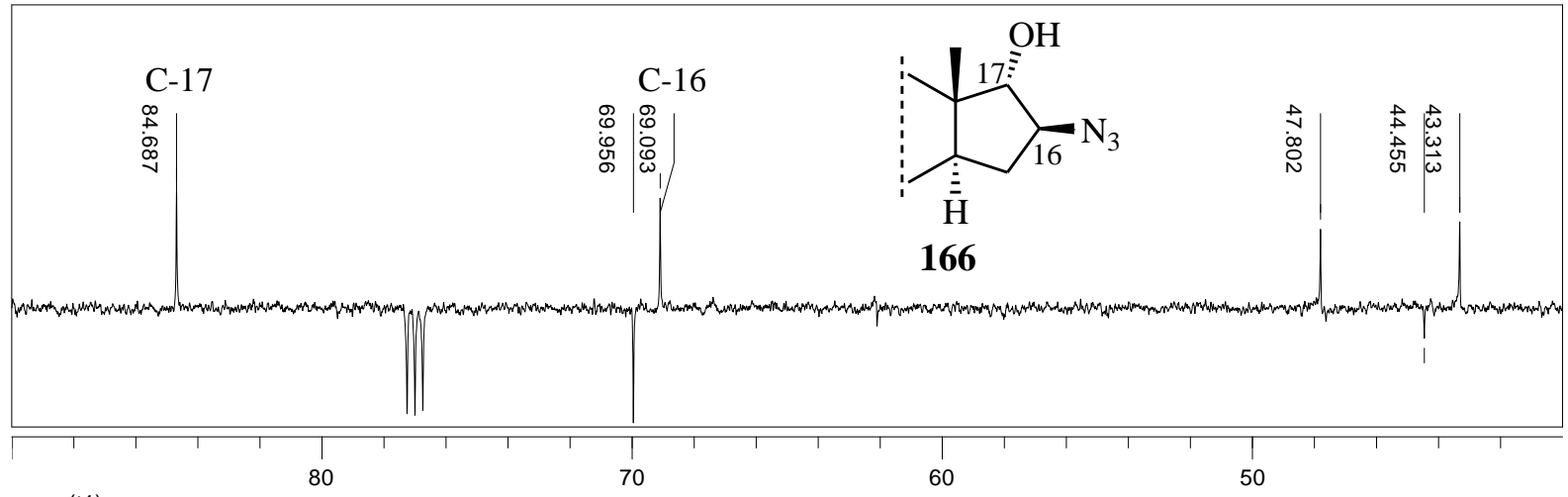

$\operatorname{ppm}(\mathrm{t} 1)$

52. ábra: Az $\alpha$-epoxid (163) ${ }^{13}$ C-NMR spektrumának összehasonlítása a 16ß-azido-17 $\alpha$ hidroxi származék (166) ${ }^{13} \mathrm{C}$-NMR felvételével

Az 53. ábrán a 170b ${ }^{1}$ H-NMR spektruma látható. A legmagasabb kémiai eltolódású protonjel (7,7 ppm) a triazol-gyürü egyetlen protonjához rendelhető. A 6,7 és 7,5 ppm közötti tartományban a benzil-védőcsoport, az aromás A-gyürü és a tolil-gyürű protonjainak jelei láthatók. 1,0 és 2,4 ppm-nél az anguláris és a 3"'-metilcsoport hármas intenzitású szingulettjei figyelhetők meg. Mindezek arra utalnak, hogy az 1,3-dipoláris cikloaddíció eredményeként valóban a kívánt célterméket (170b) kaptuk. 


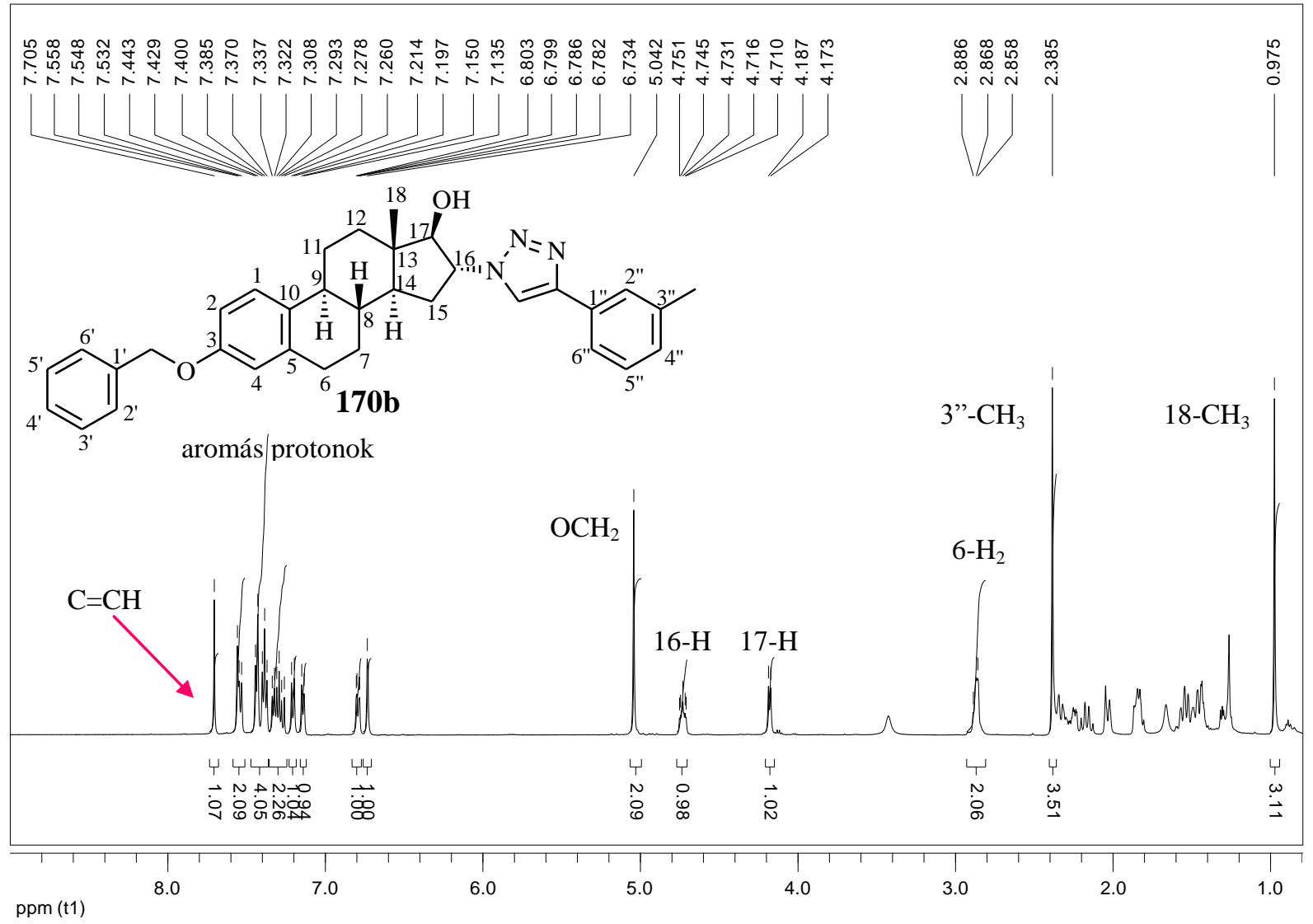

53. ábra: A 170b ${ }^{1} \mathrm{H}-\mathrm{NMR}$ spektruma

Az azidoketon (171) ${ }^{1}$ H-NMR felvétele jól mutatja, hogy a 166-os azidoalkohol 17OH-csoportjának oxidációja sikeresen végbement, hiszen 3,8 ppm körül hiányzik a 17-H szingulettje, továbbá a 171-es vegyület ${ }^{13} \mathrm{C}$-NMR spektrumában 215 ppm-nél megjelenik a ketocsoport kvaterner szénatomjának a jele. A 171-es származék redukciójával nyert 16 $\beta$ azido-3-benziloxiösztra-1,3,5(10)-trién-17ß-ol (172) ${ }^{1} \mathrm{H}-\mathrm{NMR}$ spektrumában két egységnyi intenzitású jelet detektáltunk 3,6 ppm és 4,1 ppm körül, amelyek a 16-H-hoz és a 17-H-hoz rendelhetők. Az 54. ábra a szteroid-olefin (162) és a katalitikus hidrogénezésével előállított vegyület (173) ${ }^{1} \mathrm{H}-\mathrm{NMR}$ spektrumrészlete látható. Megfigyelhető, hogy az alkén (162) 16-H és 17-H multiplettjei, illetve a benzil-védőcsoport aromás jelei a 173-os származék ${ }^{1} \mathrm{H}-\mathrm{NMR}$ felvételén nem láthatók, amely a sikeresen végbement hidrogénezésre utal. 

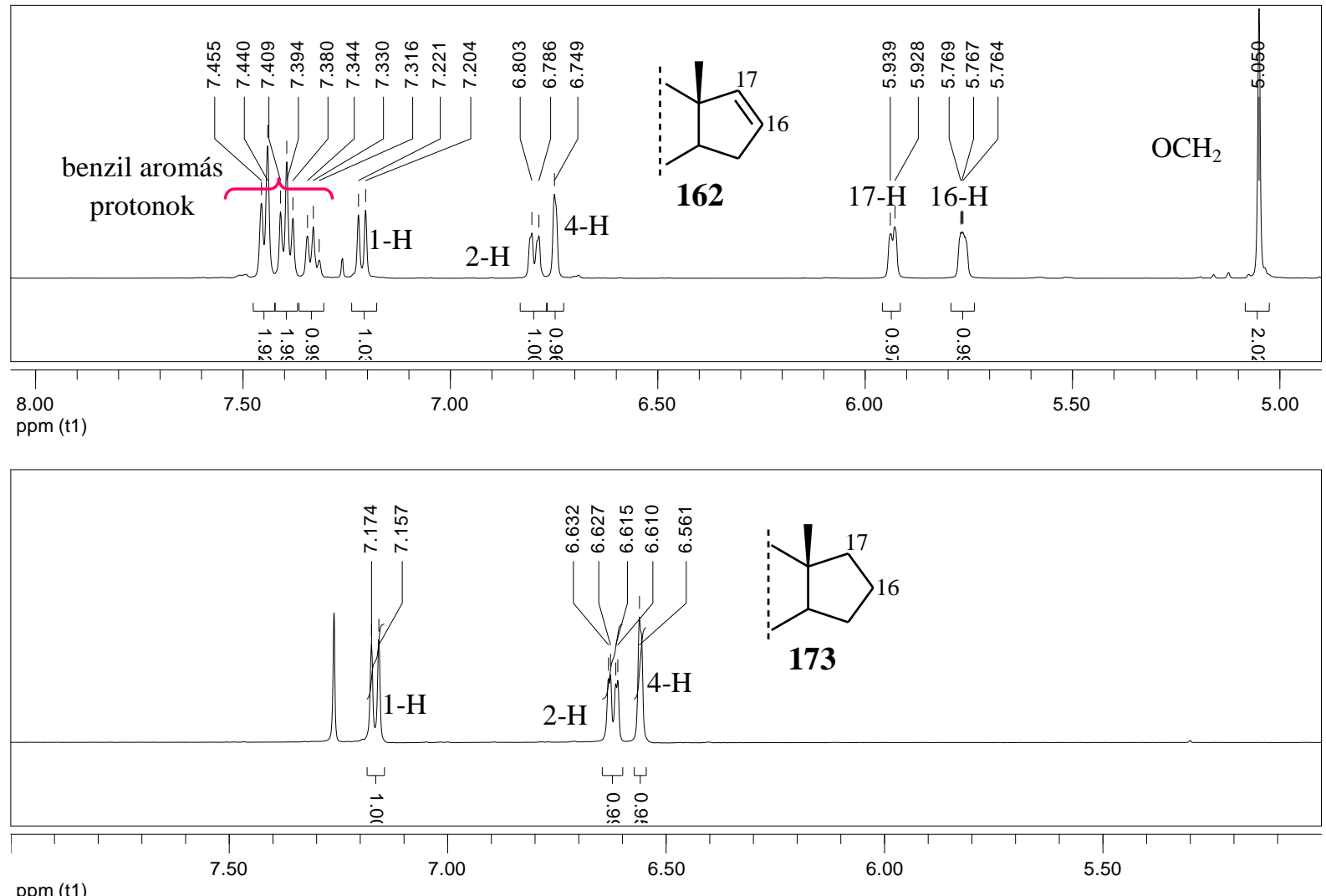

54. ábra: A szteroid-olefin (162) és a katalitikus hidrogénezésével nyert vegyület $(\mathbf{1 7 3}){ }^{1} \mathrm{H}$ NMR spektrumrészlete

A közelmúltban számos kutatócsoport számolt be szteroid-triazolok humán adherens tumorsejtvonalakon mutatott antiproliferatív hatásáról (lásd 29.-32. oldal). Ezek alapján meghatároztuk az újonnan szintetizált származékok (162-173) sejtosztódást gátló hatását in vitro MTT-módszer segítségével, négy különböző humán adherens sejtvonalon (Hela, MCF7, A2780, A431). Az 5. táblázat foglalja össze az elöállított vegyületek (162-173) antiproliferatív hatását. Az 5. táblázatból kitünik, hogy az olefin (162) nem mutatott jelentős antitumor hatást, ugyanakkor a 17-dezoxi-számazék (173) $30 \mu \mathrm{M}$-os koncentrációja 90\%-nál nagyobb sejtosztódás gátlást eredményezett mind a négy sejtvonalon. Az epoxidok $(\mathbf{1 6 3}, \mathbf{1 6 5})$ kevésbé gátolták a sejtosztódást, mint az azidoalkoholok $(\mathbf{1 6 6}, \mathbf{1 6 7})$. Megfigyeltük, hogy a $17 \alpha-\mathrm{OH}$-csoporttal rendelkező vegyület (166) potensebbnek bizonyult a 17ß-hidroxi származékokhoz $(\mathbf{1 6 7}, 172)$ képest. E két utóbbi szteroid (167, 172) azonban tumorszelektívnek mutatkozott az A431-es $\left(\mathbf{1 6 7}, \mathrm{IC}_{50}=8,1 \mu \mathrm{M}\right)$ és az A2780-as sejtvonalakon $\left(\mathbf{1 7 2}, \mathrm{IC}_{50}=10,7 \mu \mathrm{M}\right)$. A 16-triazolil-vegyületek $(169 \mathbf{a}-\mathbf{c}$, e és 170a-c, e) biológiai aktivitását összevetve a nekik megfelelő azidoalkoholokéval $(\mathbf{1 6 6}, \mathbf{1 6 7})$ kitünik, 
hogy az azido-funkció triazolil-gyürüre történő cseréje az antiproliferatív hatás csökkenését eredményezi. Az is megállapítható, hogy a fenilacetilénből származó szubsztituensek minősége és helyzete nem befolyásolta jelentősen az antiproliferatív hatást. Egyedül a 4"- $\mathrm{CF}_{3}$ szubsztituens (169d, 170d) esetén tapasztaltunk említést érdemlő sejtosztódás-gátlást. A 17keton (171) kevésbé bizonyult hatékonynak, mint az azidoalkoholok $(\mathbf{1 6 6}, \mathbf{1 6 7}, 172)$, ezzel is utalva arra, hogy a 17-es helyzetü oxigéntartalmú funkciós csoport minősége nagymértékben befolyásolja a biológiai aktivitást. A brómhidrin (164) az azidoalkoholokhoz (167, 172) hasonlóan viselkedik az A2780 $\left(\mathrm{IC}_{50}=8,6 \mu \mathrm{M}\right)$ és az A431 sejtvonalon $\left(\mathrm{IC}_{50}=12,6 \mu \mathrm{M}\right)$.

\begin{tabular}{|c|c|c|c|c|c|}
\hline \multirow[b]{2}{*}{ Vegyiulet } & \multirow[b]{2}{*}{$\begin{array}{l}\text { Konc. } \\
(\mu \mathrm{M})\end{array}$} & \multicolumn{4}{|c|}{ 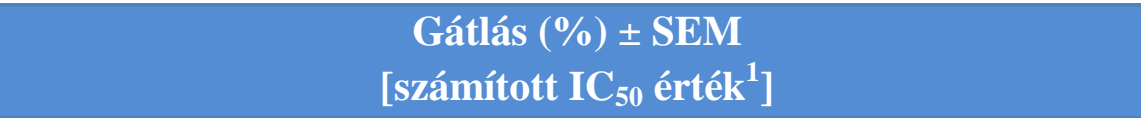 } \\
\hline & & Hela & MCF-7 & A2780 & A431 \\
\hline \multirow{2}{*}{162} & 10 & $3,7 \pm 0,4$ & $2,0 \pm 1,0$ & $3,8 \pm 0,9$ & $3,2 \pm 0,3$ \\
\hline & 30 & $12,2 \pm 1,5$ & $18,8 \pm 1,1$ & $13,8 \pm 0,8$ & $20,6 \pm 0,7$ \\
\hline \multirow{2}{*}{163} & 10 & $9,5 \pm 0,9$ & $10,5 \pm 1,0$ & $12,5 \pm 1,3$ & $12,4 \pm 0,7$ \\
\hline & 30 & $39,7 \pm 1,1$ & $34,7 \pm 1,7$ & $37,9 \pm 1,0$ & $42,1 \pm 0,7$ \\
\hline \multirow{3}{*}{164} & 10 & $17,3 \pm 0,8$ & $7,1 \pm 0,9$ & $43,5 \pm 0,7$ & $32,9 \pm 2,2$ \\
\hline & 30 & $86,2 \pm 0,6$ & $80,4 \pm 0,6$ & $93,8 \pm 0,6$ & $95,7 \pm 0,5$ \\
\hline & & & & {$[8,6 \mu \mathrm{M}]$} & {$[12,6 \mu \mathrm{M}]$} \\
\hline \multirow{2}{*}{165} & 10 & $7,5 \pm 0,6$ & $4,6 \pm 1,8$ & $7,3 \pm 1,2$ & $13,3 \pm 0,3$ \\
\hline & 30 & $33,9 \pm 1,4$ & $14,0 \pm 0,8$ & $20,2 \pm 0,6$ & $30,6 \pm 1,2$ \\
\hline \multirow{3}{*}{166} & 10 & $12,2 \pm 0,7$ & $67,9 \pm 1,0$ & $45,1 \pm 1,3$ & $84,4 \pm 0,9$ \\
\hline & 30 & $96,8 \pm 0,2$ & $93,9 \pm 0,4$ & $95,0 \pm 0,5$ & $97,2 \pm 0,3$ \\
\hline & & & {$[13,2 \mu \mathrm{M}]$} & {$[12,3 \mu \mathrm{M}]$} & {$[13,2 \mu \mathrm{M}]$} \\
\hline \multirow{3}{*}{167} & 10 & $23,6 \pm 2,3$ & $25,0 \pm 1,8$ & $25,2 \pm 1,5$ & $92,1 \pm 0,5$ \\
\hline & 30 & $91,3 \pm 0,5$ & $85,2 \pm 0,6$ & $94,6 \pm 0,3$ & $95,9 \pm 0,1$ \\
\hline & & & & & {$[8,1 \mu \mathrm{M}]$} \\
\hline \multirow{2}{*}{$169 a$} & 10 & $36,2 \pm 1,1$ & $23,1 \pm 2,3$ & $39,7 \pm 0,7$ & $23,6 \pm 2,0$ \\
\hline & 30 & $55,0 \pm 0,4$ & $43,0 \pm 2,9$ & $45,6 \pm 2,5$ & $36,3 \pm 2,9$ \\
\hline \multirow{2}{*}{$170 a$} & 10 & $30,0 \pm 2,0$ & $32,0 \pm 2,0$ & $38,1 \pm 1,5$ & $20,9 \pm 0,5$ \\
\hline & 30 & $34,6 \pm 1,4$ & $52,5 \pm 1,8$ & $44,6 \pm 1,2$ & $22,9 \pm 1,0$ \\
\hline \multirow{2}{*}{$169 b$} & 10 & $12,8 \pm 0,4$ & $18,1 \pm 2,0$ & $23,6 \pm 0,8$ & $4,6 \pm 0,9$ \\
\hline & 30 & $14,1 \pm 0,8$ & $25,6 \pm 2,7$ & $26,2 \pm 0,5$ & $9,5 \pm 1,6$ \\
\hline $170 b$ & 10 & $27,4 \pm 0,7$ & $23,9 \pm 1,4$ & $30,2 \pm 2,3$ & $14,6 \pm 1,8$ \\
\hline
\end{tabular}




\begin{tabular}{|c|c|c|c|c|c|}
\hline & 30 & $37,3 \pm 0,7$ & $27,9 \pm 2,4$ & $34,7 \pm 2,3$ & $21,9 \pm 2,2$ \\
\hline \multirow{2}{*}{$169 \mathrm{c}$} & 10 & $30,1 \pm 0,9$ & $23,1 \pm 0,9$ & $20,9 \pm 0,7$ & $23,6 \pm 1,2$ \\
\hline & 30 & $34,2 \pm 0,8$ & $39,9 \pm 0,7$ & $26,7 \pm 1,4$ & $31,4 \pm 1,1$ \\
\hline \multirow{2}{*}{$170 c$} & 10 & $44,4 \pm 2,1$ & $12,1 \pm 1,2$ & $30,1 \pm 0,8$ & $7,8 \pm 1,9$ \\
\hline & 30 & $50,6 \pm 1,8$ & $24,0 \pm 2,8$ & $37,4 \pm 0,4$ & $9,8 \pm 1,9$ \\
\hline \multirow{3}{*}{ 169d } & 10 & $60,8 \pm 1,8$ & $41,1 \pm 1,4$ & $30,2 \pm 3,1$ & $16,6 \pm 1,7$ \\
\hline & 30 & $50,6 \pm 4,7$ & $75,5 \pm 0,4$ & $57,8 \pm 1,2$ & $37,2 \pm 1,5$ \\
\hline & & & {$[11,5 \mu \mathrm{M}]$} & & \\
\hline \multirow{3}{*}{ 170d } & 10 & $73,7 \pm 2,9$ & $29,9 \pm 0,5$ & $44,1 \pm 2,6$ & $14,6 \pm 1,5$ \\
\hline & 30 & $75,2 \pm 2,6$ & $48,4 \pm 1,9$ & $54,9 \pm 1,2$ & $21,8 \pm 3,6$ \\
\hline & & {$[9,5 \mu \mathrm{M}]$} & & & \\
\hline \multirow{2}{*}{$169 e$} & 10 & $30,0 \pm 1,0$ & $18,2 \pm 2,1$ & $36,5 \pm 0,9$ & $12,5 \pm 1,4$ \\
\hline & 30 & $34,3 \pm 1,5$ & $32,1 \pm 0,7$ & $38,5 \pm 1,3$ & $18,0 \pm 0,9$ \\
\hline \multirow{2}{*}{ 170e } & 10 & $6,4 \pm 2,6$ & $12,7 \pm 0,8$ & $31,2 \pm 3,0$ & $16,7 \pm 0,9$ \\
\hline & 30 & $29,6 \pm 3,1$ & $14,7 \pm 0,3$ & $34,7 \pm 1,8$ & $18,2 \pm 1,7$ \\
\hline \multirow{2}{*}{171} & 10 & $15,5 \pm 1,2$ & $17,8 \pm 1,0$ & $15,8 \pm 2,1$ & $8.9 \pm 0,9$ \\
\hline & 30 & $35,3 \pm 2,0$ & $30,8 \pm 0,5$ & $28,4 \pm 0,9$ & $11,9 \pm 3,3$ \\
\hline \multirow{3}{*}{172} & 10 & $13,7 \pm 1,6$ & $15,1 \pm 1,3$ & $46,3 \pm 1,1$ & $57,1 \pm 1,2$ \\
\hline & 30 & $47,4 \pm 0,7$ & $60,1 \pm 1,3$ & $71,4 \pm 0,8$ & $77,9 \pm 1,0$ \\
\hline & & & & {$[10,7 \mu \mathrm{M}]$} & \\
\hline \multirow{2}{*}{173} & 10 & $6,3 \pm 0,5$ & $20,9 \pm 2,3$ & $17,8 \pm 0,5$ & $2,7 \pm 0,9$ \\
\hline & 30 & $97,4 \pm 0,1$ & $91,4 \pm 0,5$ & $93,6 \pm 0,3$ & $96,7 \pm 0,2$ \\
\hline \multirow{3}{*}{ Ciszplatin } & 10 & $42,6 \pm 2,3$ & $53,0 \pm 2,3$ & $83,6 \pm 1,2$ & $88,6 \pm 0,5$ \\
\hline & 30 & $99,9 \pm 0,3$ & $86,9 \pm 1,3$ & $95,0 \pm 0,3$ & $90,2 \pm 1,8$ \\
\hline & & {$[12,4 \mu \mathrm{M}]$} & {$[9,6 \mu \mathrm{M}]$} & {$[1,3 \mu \mathrm{M}]$} & {$[2,8 \mu \mathrm{M}]$} \\
\hline
\end{tabular}

${ }^{1}$ Középértéke a két különböző, egymástól független, 5 párhuzamos csatornával végrehajtott meghatározásnak, a standard deviáció kisebb, mint $15 \%$

${ }^{2}<20 \%$ gátlás \% értékeket nem tüntettük fel, a könnyebb áttekinthetőség érdekében

5. táblázat: Az újonnan előállított vegyületek (162-173) sejtosztódást gátló hatása négy különböző humán adherens tumorsejtvonalon 


\subsection{A $\delta$-alkenil-D-szekoösztronok Lewis-sav-indukált „,one pot” Prins-Ritter reakciói}

Kutatómunkánk következő részében folytattuk az új, nitrogéntartalmú D-homoösztron

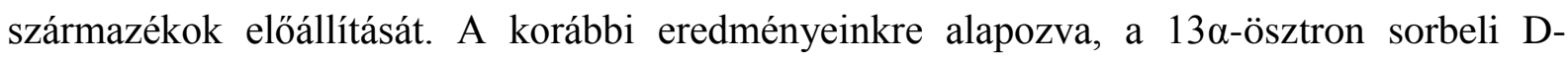
szekoaldehid 3-metil- és 3-benzil-éterét $(\mathbf{1 0 2}, \mathbf{1 0 3})$ Lewis-sav-indukált Prins-reakcióval Dhomológokká (177-182) alakítottuk, majd a 16-os szénatomon kialakuló karbokationra nukleofil beépítését valósítottuk meg a Ritter-reakció kísérleti körülményei között, „one pot” eljárással (56. ábra, 6. táblázat). ${ }^{110}$ Lewis-sav katalizátorként $\mathrm{BF}_{3} \cdot \mathrm{OEt}_{2}$-ot, oldószerként és nukleofil reagensként pedig különböző nitrileket (acetonitril (174), klóracetonitril (175), benzonitril (176) használtunk. A szintéziseket szobahőmérsékleten végeztük, ekvimoláris mennyiségü $\mathrm{BF}_{3} \cdot \mathrm{OEt}_{2}$ diklórmetános oldatát adagolva a reakcióelegyhez. Valamennyi reakció pár perc alatt lejátszódott. Az 55. ábra a Prins-Ritter reakció feltételezett mechanizmusát szemlélteti. A 16-os szénatomra a nitril (III) intézett nukleofil támadást, majd a képződött átmeneti termékek (V) víz hatására iminol-acilamino tautomer átrendeződéssel acilamino származékokká (VI) alakultak tovább. A szekoaldehidek $(\mathbf{1 0 2}, \mathbf{1 0 3})$ gyürüzárása során így két új kiralitáscentrum (C-16 és C-17a) alakult ki, amelyek négy sztereoizomer képződésére adtak volna lehetőséget. 16-Fluorszármazékok (IV) képződését egyik reakcióban sem figyeltük meg. Ennek oka lehet, hogy a nitrilt (III) nagy feleslegben alkalmazva, a fluoridion nukleofilként való támadása nem valósul meg. 
<smiles>C=CC[C@H](I)[C@H](I)C=O</smiles>

102,103

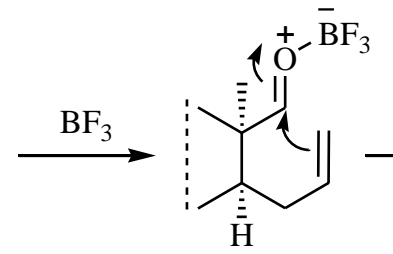

I

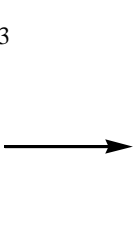

$-1 \mathrm{Et} \mathrm{O}$

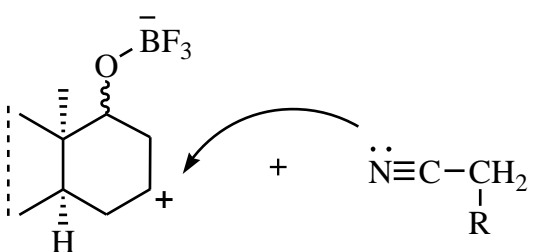

II

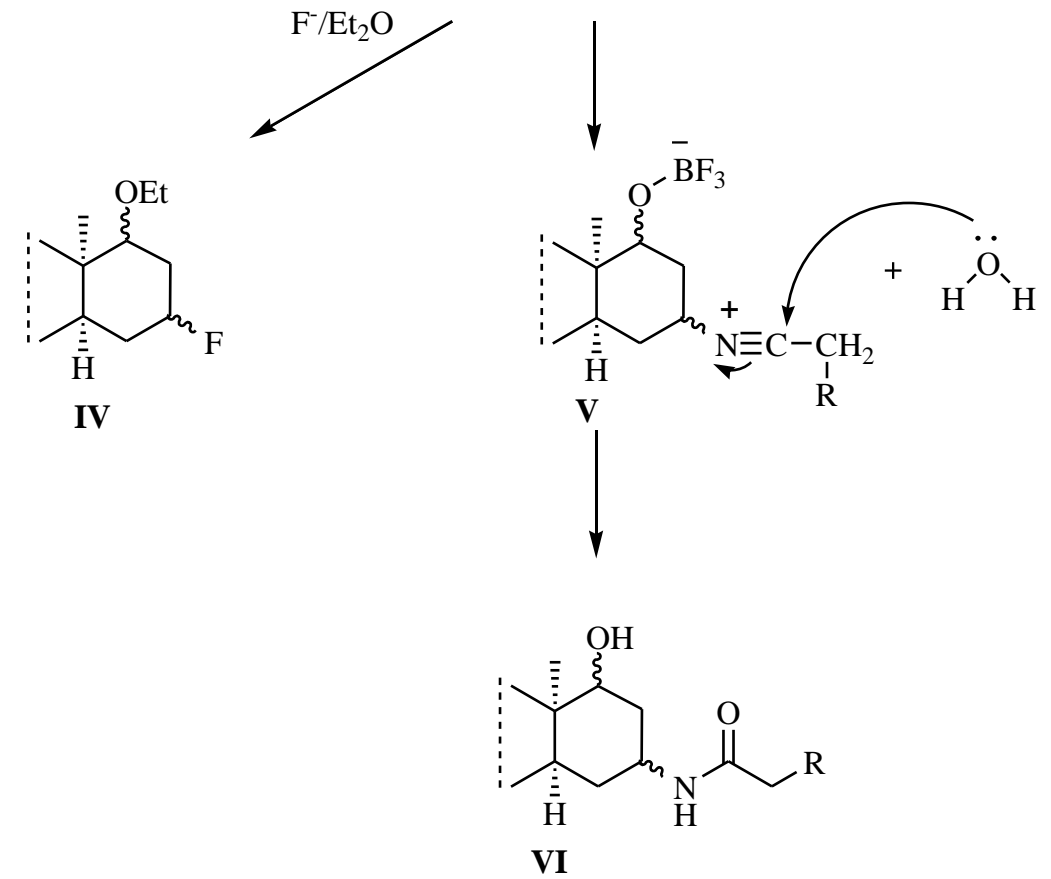

55. ábra: A Prins-Ritter reakció mechanizmusa

A folyamatok sztereoszelektíven játszódtak le, két-két Prins-Ritter terméket szolgáltatva (177a-182a és 177b-182b), 4:1 arányban (56. ábra, 6. táblázat). A főtermékek, a 16 $\beta$-acilamino-17a $\alpha$-hidroxi vegyületek (177a-182a) minden reakcióban nagy feleslegben képződtek, míg mindhárom nitril (174-176) esetén megjelent egy új, áthidalt típusú melléktermék (177b-182b) is a reakcióelegyben. Klóracetonitril (175) alkalmazásakor három termék (178a-c vagy 181a-c) képződött, 7:2:1 arányban. Az áthidalt vegyület $(\mathbf{1 7 7 b}-\mathbf{1 8 2 b})$ kialakulásának feltételezett mechanizmusát irodalmi példákra alapozzuk. ${ }^{111,112}$ 


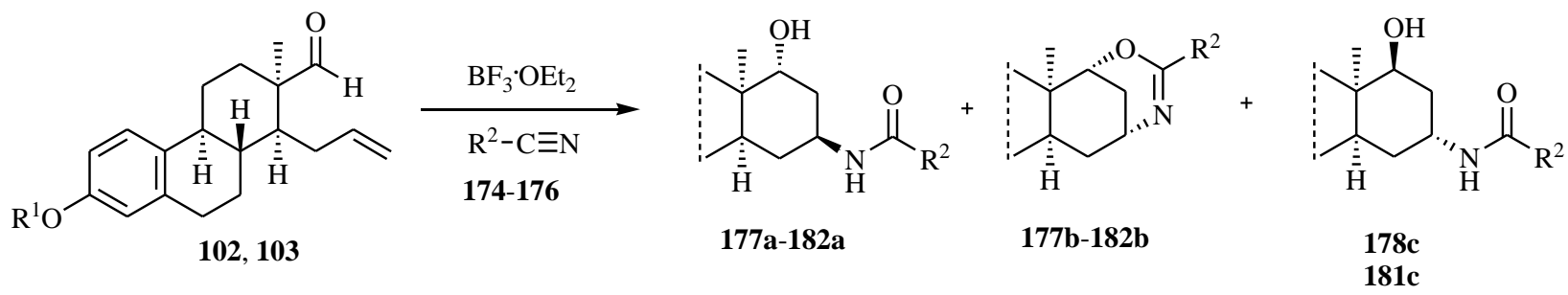

102, 177-179: $\mathrm{R}^{1}=\mathrm{Me} \quad 174,177,180: \mathrm{R}^{2}=\mathrm{Me}$

103, 180-182: $\mathrm{R}^{1}=\mathrm{Bn} \quad 175,178,181: \mathrm{R}^{2}=\mathrm{CH}_{2} \mathrm{Cl}$

176, 179, 182: $\mathrm{R}^{2}=\mathrm{Ph}$

56. ábra: A D-szekoaldehidek $(\mathbf{1 0 2}, \mathbf{1 0 3})$ átalakításai Prins-Ritter reakcióval

\begin{tabular}{|c|c|c|c|}
$\begin{array}{c}\text { Kiindulási } \\
\text { aldehid }\end{array}$ & Nitril & Termékek & Hozamok (\%) \\
\hline $\mathbf{1 0 2}$ & $\mathbf{1 7 4}$ & $\mathbf{1 7 7 a + 1 7 7 b}$ & $78+21$ \\
\hline $\mathbf{1 0 2}$ & $\mathbf{1 7 5}$ & $\mathbf{1 7 8 a + 1 7 8 b + 1 7 8 c}$ & $64+19+9$ \\
\hline $\mathbf{1 0 2}$ & $\mathbf{1 7 6}$ & $\mathbf{1 7 9 a + 1 7 9 b}$ & $76+20$ \\
\hline $\mathbf{1 0 3}$ & $\mathbf{1 7 4}$ & $\mathbf{1 8 0 a + 1 8 0 b}$ & $74+20$ \\
\hline $\mathbf{1 0 3}$ & $\mathbf{1 7 5}$ & $\mathbf{1 8 1 a + 1 8 1 b + 1 8 1 c}$ & $65+19+9$ \\
\hline $\mathbf{1 0 3}$ & $\mathbf{1 7 6}$ & $\mathbf{1 8 2 a + 1 8 2 b}$ & $71+18$ \\
\hline
\end{tabular}

6. táblázat: A Prins-Ritter termékek (177-182) hozamai

Ismeretes, hogy a 3-( $N$-acilamino)-szubsztituált karán-4-on-oximok (VII) tömény kénsav jelenlétében, kloroformos közegben, szobahőmérsékleten átrendeződnek, és áthidalt szerkezetü dihidrooxazinokat (2-oxa-4-azabiciklo[3.3.1]non-3-én származékokat, XIII) adnak. $^{112}$ A feltételezett mechanizmus szerint a VII vegyület kvaterner szénatomja protonálódik (VIII), a ciklopropán gyürü felnyílik (IX), és az 57. ábrán látható karbokation (IX) képződik. Az 1,2-hidrideltolódás során 1,3-( $N$-acilamino)-karbokation $(\mathbf{X})$ alakul ki, ahol a karbokationra az amidcsoport oxigénje támad, így kialakítva a dihidro-1,3-oxazin gyürüt (XIII). 


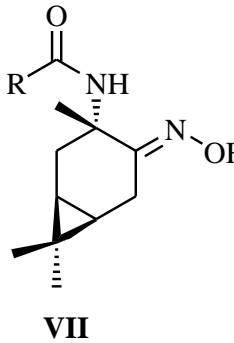

VII<smiles>[R]C(=O)N[C@@]1(C)C[C@H](C(C)C)CC/C1=N\O</smiles>

$\mathbf{X}$

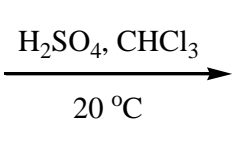

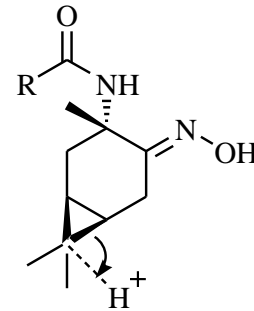

VIII<smiles>[R]C(=O)N[C@@]1(C)C[C@H](C(C)CC)[CH+]C/C1=N\O</smiles>

IX<smiles>[R]C(=O)[C@@]1(C(C)C)CC/C(=N\O)[C@](C)(O)C1</smiles><smiles>[R]C(=O)N[C@@]1(C)CC/C(=N\O)[C@](C)(C(C)C)C1</smiles>

57. ábra: A 3-(N-Acilamino)-szubsztituált karán-4-on-oximok dihidro-1,3-oxazinokká történő átrendeződése

Ez utóbbi eredmény alapján feltételezzük, hogy a Prins-Ritter reakcióban átmenetileg a, $\alpha$-mellékizomerek (177b-182b) képződnek, amelyek 17a-szénatomján a hidroxilcsoport Lewis-sav-indukált eliminációját követően szekunder karbokation alakul ki, amelyre az amid oxigénatomja indít nukleofil támadást, így létrehozva a dihidro-1,3-oxazinokat (177b-182b, 58. ábra).<smiles>[Y19]N[C@@H]1C[C@@H](I)C(I)(I)[C@@H](O)C[C@@H]1NC([R])=O</smiles>

58.ábra: A dihidrooxazinok (177b-182b) képződésének feltételezett mechanizmusa

A Prins-Ritter termékek (177-182) szerkezetbizonyítását egy- és kétdimenziós NMRfelvételek, valamint az irodalomban ismeretes hasonló szerkezetü vegyületek megfelelő adatai segítették. $^{92,113,114} \mathrm{Az}$ 59. ábra az acetonitriles reakcióban nyert 16 $\beta$-acetilamino-17a $\alpha-$ 
hidroxi főtermék (180a) ${ }^{1} \mathrm{H}-\mathrm{NMR}$ spektrumát mutatja. A felvételen 1,7 ppm-nél az acetonitrilből származó acetil-metilcsoport hármas intenzitású szingulettje, 3,7 és 3,8 ppm között a 16-H és a 17a-H multiplettjei, 4,4 ppm kémai eltolódásnál a 17a-hidroxil-funkció, míg 7,7 ppm-nél az NH szingulettje látható. A ${ }^{13} \mathrm{C}-\mathrm{NMR}$ spektrumban az acetil-metilcsoport jele 23 ppm kémiai eltolódásnál figyelhető meg, továbbá az $N$-acetil-funkciónak a molekulába történt beépülésére a 168 ppm-nél megjelenő NCO jel utal.

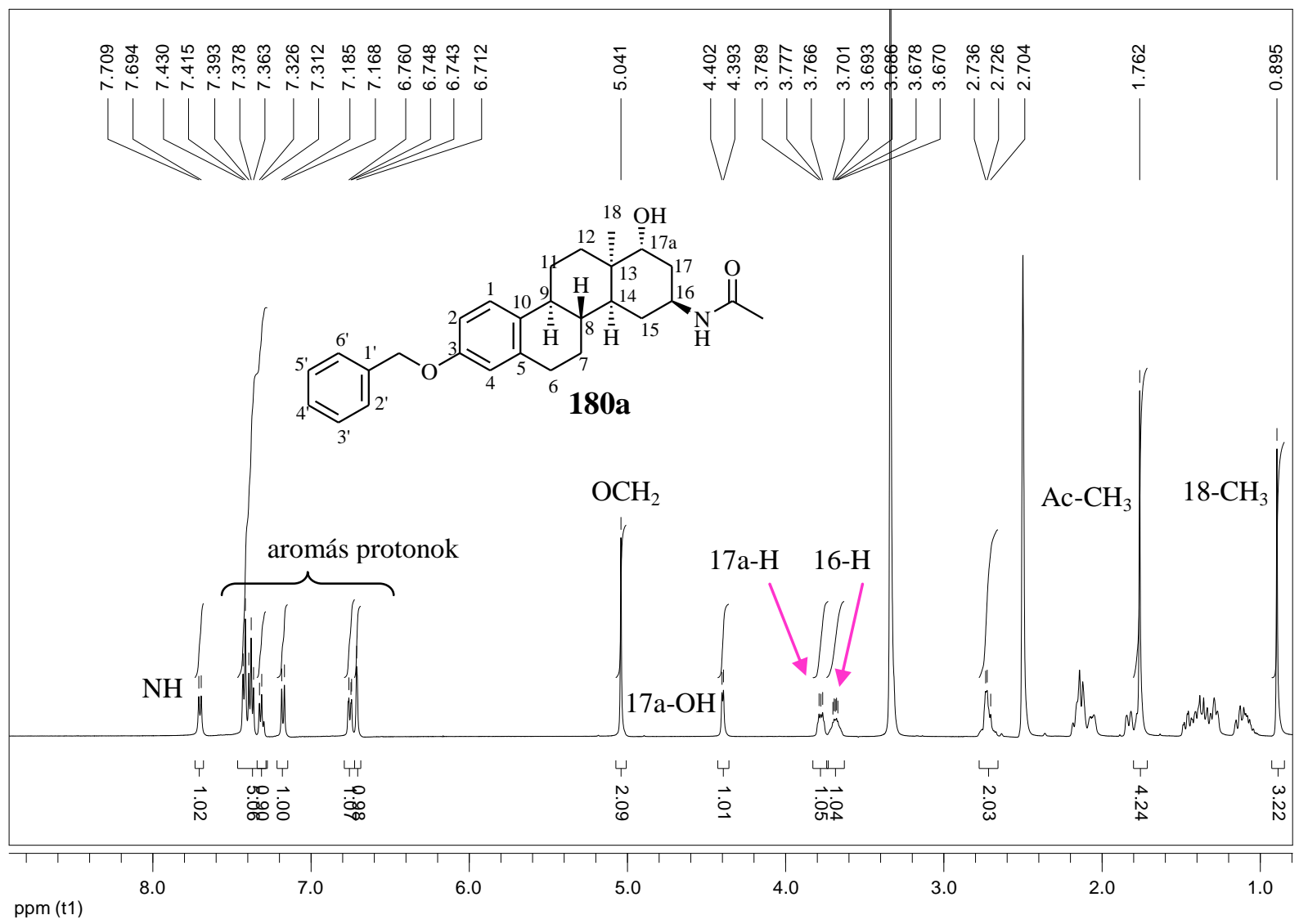

59. ábra: A 16 $\beta$-acetilamino-17a $\alpha$-hidroxi fötermék (180a) ${ }^{1} \mathrm{H}-\mathrm{NMR}$ spektruma

A vegyület 16-os és 17a-szénatomjai konfigurációjának meghatározása érdekében 2DNMR felvételeket készítettünk, továbbá összehasonlítottuk azokat a korábban előállított Dhomoösztron származék (104) megfelelő spektrumaival és röntgendiffrakciós felvételével (60. ábra). ${ }^{92}$ A 60 . ábrán jól látható, hogy a D-gyürű $\alpha$-helyzetü etoxi- és fluor-szubsztituensei ekvatoriálisak. Az új vegyületek NMR-spektrumai arra utalnak, hogy az általunk szintetizált főtermékek (177a-182a) 16ß-acilamino-csoportot tartalmaznak, amelyek feltehetően axiális 
térhelyzetủek. Ennek oka lehet az $N$-acetil-funkció oxigénatomja és a 17a-hidroxilcsoport között kialakuló erős másodrendü kölcsönhatás.

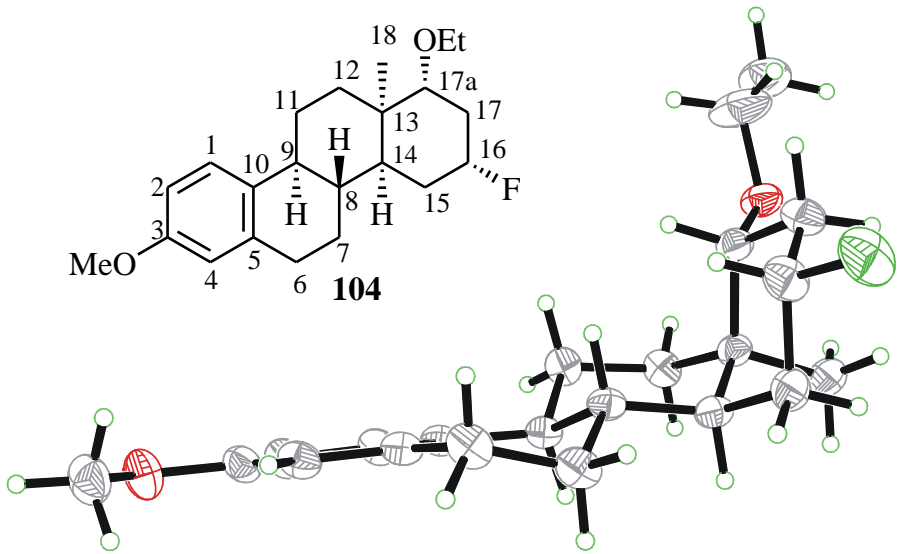

60. ábra: A 104-es jelü vegyület röntgendiffrakcióval kapott szerkezete

A 61. ábra az acetonitriles reakcióban nyert dihidrooxazin (180b) protonspektrumát szemlélteti. Az ábrából kitünik, hogy a vegyület (180b) nem a Prins-Ritter reakció várt sztereoizomereinek egyike, hanem egy új típusú származék. Az ${ }^{1} \mathrm{H}-\mathrm{NMR}$ spektrumokat összehasonlítva megállapítottuk, hogy a fö- (180a) és a melléktermék (180b) mérvadó protonjeleinek eltérő multiplicitása és kémiai eltolódása utal az eltérő szerkezetre. Míg a főtermék (180a) protonspektrumában a 16-H és a 17a-H multiplettek, addig az áthidalt melléktermék (180b) esetében ugyanezen jelek kiszélesedett szingulettként láthatók. Továbbá a főtermékre (180a) jellemző NH-csoport szingulettje hiányzik a 6 ppm feletti tartományban. Megfigyeltük, hogy a melléktermék (180b) ${ }^{13} \mathrm{C}-\mathrm{NMR}$ spektrumában az NCO jel sokkal alacsonyabb kémiai eltolódásnál (159 ppm) látható, mint a fötermék (180a) NCO szénatomjának a jele (168 ppm). 


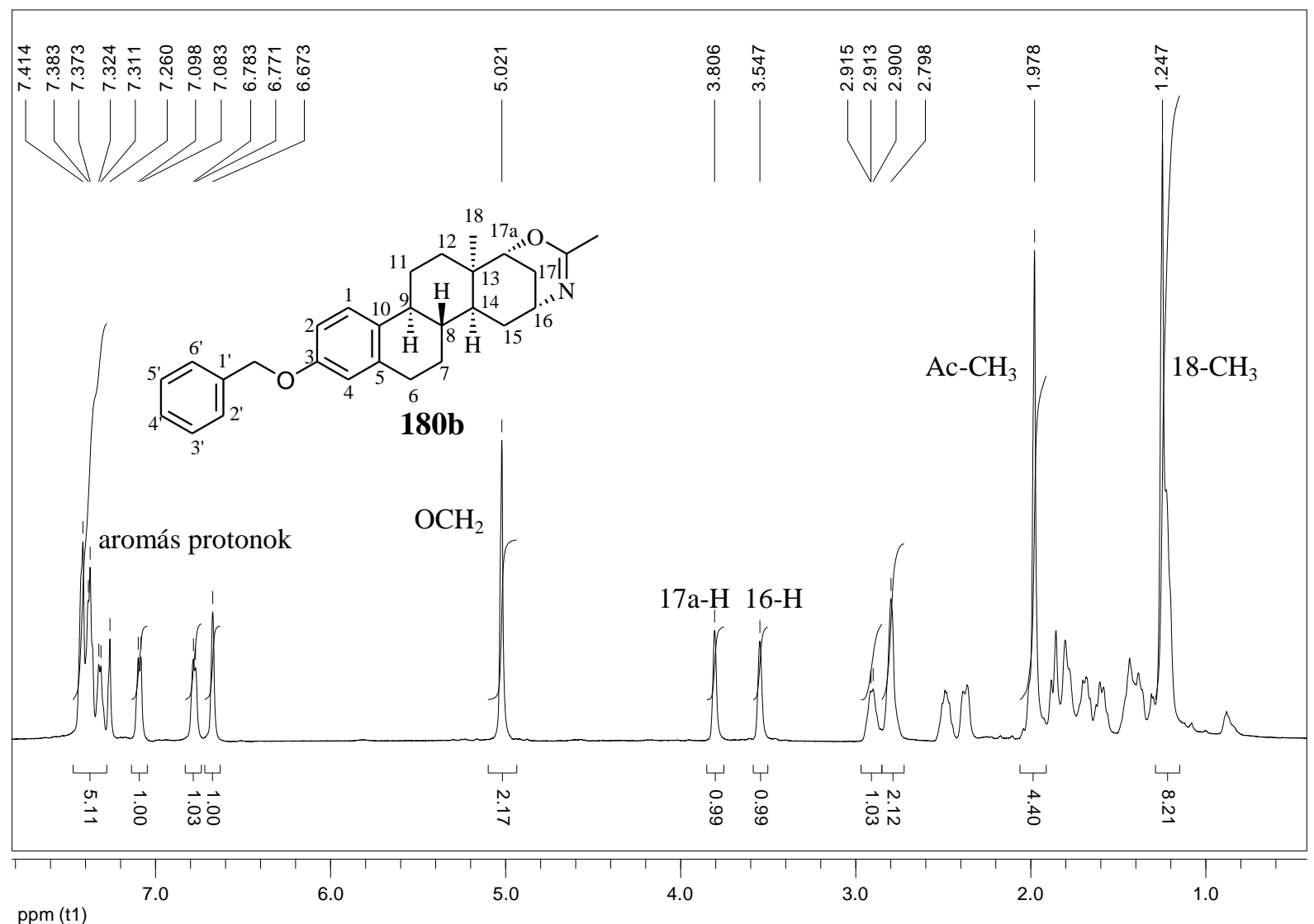

61. ábra: A 180b jelü vegyület ${ }^{1}$ H-NMR felvétele

Az 180b szerkezetigazolásában további segítséget nyújtott a Kutatócsoportunk által korábban szintetizált ösztránvázas $16 \alpha, 17 \alpha$-dihidro-1,3-oxazin (183, 62. ábra) ${ }^{13} \mathrm{C}-\mathrm{NMR}$ felvétele. ${ }^{113,114}$ A 183 szénspektrumán az NCO szén jele a C-3-as jel (157ppm) közelében, 159 ppm kémiai eltolódásnál figyelhető meg. A 180b NCO jele az irodalmi példához hasonlóan, 159 ppm-nél jelent meg közvetlenül a C-3 jel (156 ppm) mellett, ez is arra utal, hogy a 180b nem savamid jellegü, hanem dihidrooxazin-szerkezetet tartalmaz. A HMBC felvétel is igazolja a dihidrooxazin-jelleget, a spektrumon jól látható, hogy mind a C-16, mind a C-17a jele keresztcsúcsot ad az NCO szénatom jelével, ez pedig csak egy „gyürüs” szerkezetnél lehetséges, a fötermékhez hasonló szubsztituált vegyületnél az NCO és a C-17a jelei között nem lehetne keresztcsúcs. 


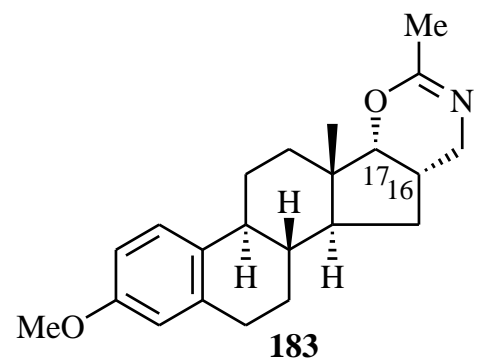

62. ábra: A 16 $\alpha, 17 \alpha$-dihidro-1,3-oxazin (183) szerkezete

A 180b C-16 és C-17a konfigurációjának megállapításában a NOESY felvétel segítette munkánkat, amelyen megfigyelhető a 16-H és a 17a-H jeleinek keresztcsúcsa, ebből következtettünk a protonok cisz-elrendeződésére. A pontos térállás meghatározásához további információkra volt szükségünk, ezért a $\mathbf{1 8 0 b}$ jelü vegyületet acetileztük. Ekkor a vegyület áthidalt gyürüs része felnyílt, 17a-acetoxi-16-acilamino származékot (184) eredményezve. Így a 63. ábrán látható, irodalomban már ismert vegyülethez (117) hasonló szubsztituáltságú homoösztronhoz jutottunk. A 64. ábra a 180b jelü vegyület acetilezésével nyert termék (184) spektrumrészletét mutatja. A két ${ }^{1} \mathrm{H}-\mathrm{NMR}$ felvételt összehasonlítva megállapíthatjuk, hogy a vegyületek $(117,184)$ 16-H és 17a-H jeleinek multiplettjei, és csatolási állandói hasonlóak, utalva az újonnan kialakult kiralitáscentrumok hasonló konfigurációira $(16 \alpha, 17 a \alpha)$. 


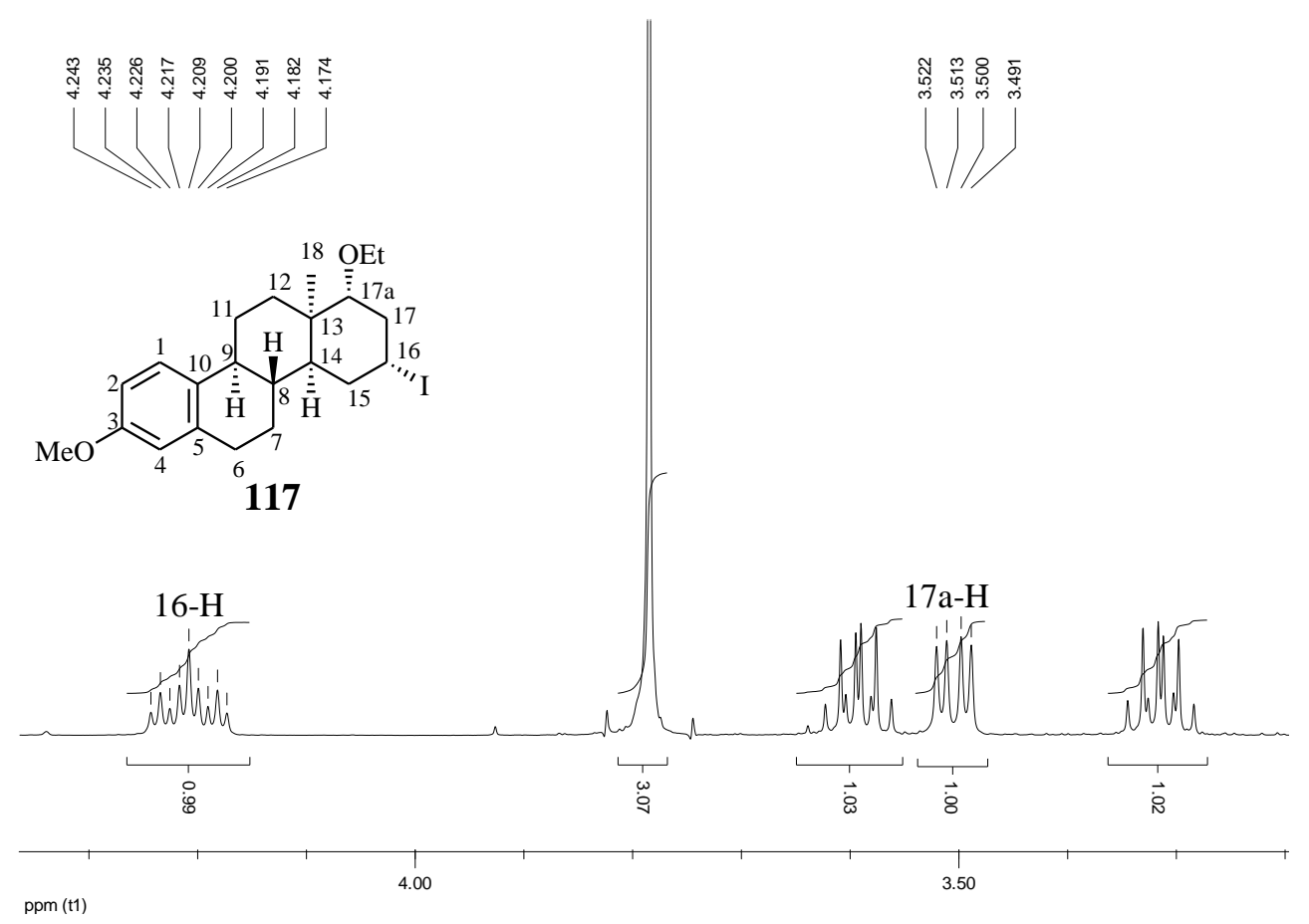

63. ábra: A 117-es jelü vegyület ${ }^{1} H-N M R$ spektrumának részlete

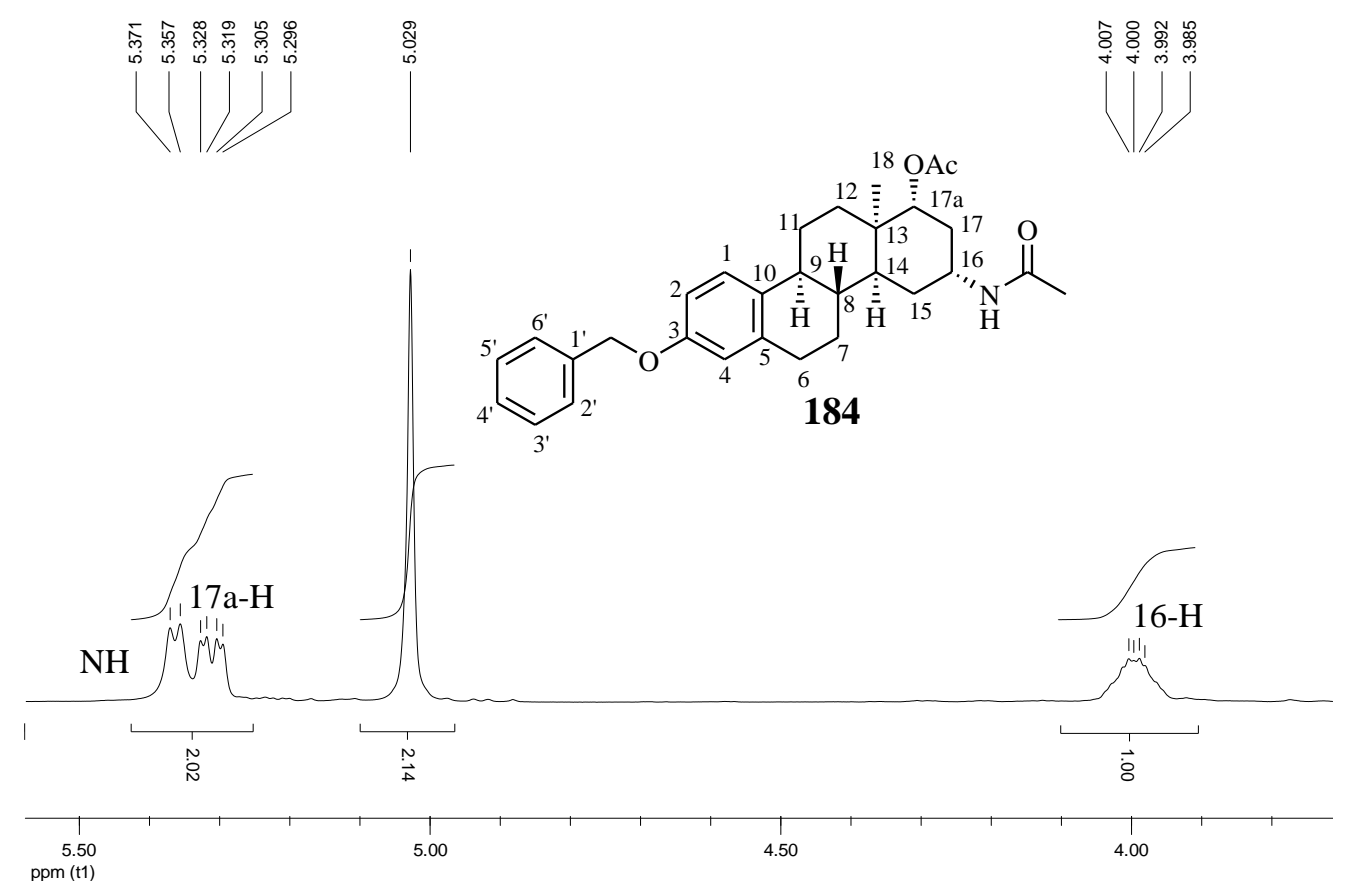

64. ábra: A 184-es jelü vegyület ${ }^{1} \mathrm{H}-\mathrm{NMR}$ spektrumának részlete 
A klóracetonitriles reakciók során a föizomerek (178a, 181a) és a dihidrooxazinok (178b, 181b) mellett megjelenő sztereoizomerek (178c, 181c) a főtermékek (178a, 181a) diasztereomer párjai. Térszerkezetük igazolását a 184-es jelü 17a-acetoxi-16-acilamino származék és a vegyületek (178c, 181c) NOESY felvételei segítették. A transz-klóracetil származékok (178c, 181c) 17a-H és 16-H jelei nem adtak egymással keresztcsúcsot. Továbbá azt tapasztaltuk, hogy míg a vegyületek (178c, 181c) 16-H-jai nem, addig a 17a-H-jai keresztcsúcsot adtak az anguláris metilcsoporttal. Ezek alapján azt a következtetést vonhatjuk le, hogy az új, kiépített funkciós csoportok melletti protonok transz-térállásúak. A 16- $N$ acetil-funkció $\alpha$-, míg a 17a-OH $\beta$-helyzetü.

Az általunk előállított vegyületek (177-182) in vitro antiproliferatív hatását Hela, A2780, A431 és MCF-7 sejtvonalakon teszteltük, MTT-módszer segítségével. A Prins-Ritter termékek (177-182) szerkezeti különbségei nagyban befolyásolták a vegyületek (177-182) sejtosztódás gátló aktivitását (7. táblázat). A táblázatból kitűnik, hogy a főtermékek (177a, 180a) kevésbé hatásosak a dihidrooxazinoknál (177b, 180b). A 180b az összes sejtvonalon a ciszplatinnal összemérhető értéket ad $\left(\mathrm{IC}_{50} \sim 1 \mu \mathrm{M}\right)$, de nem szelektál az egyes sejtvonalak között. A 3-as helyzetü benzil-védőcsoport jelenléte növeli a vegyületek sejtosztódás-gátló aktivitását. Az újonnan előállított $N$-klóracetil származékok (178, 181) szélesebb hatásspektrummal rendelkeznek, a 3-benzil-éter sorban (181a-c) 90\% körüli gátlást mutatnak mind a négy sejtvonalon. A táblázat adatainak összevetéséből arra a következtetésre jutottunk, hogy az $N$-klóracetil származékok $(\mathbf{1 7 8}, \mathbf{1 8 1})$ leginkább az A2780-as sejtek osztódását gátolják ( $\operatorname{IC}_{50}$ értékeik: $\left.0,8-2,1 \mu \mathrm{M}\right)$. Az $N$-benzoil származékok $(\mathbf{1 7 9}, \mathbf{1 8 2})$ mutatkoztak legkevésbé hatásosnak. 


\begin{tabular}{|c|c|c|c|c|c|}
\hline \multirow{2}{*}{ Vegyület } & \multirow[b]{2}{*}{$\begin{array}{c}\text { Konc. } \\
(\mu \mathrm{M})\end{array}$} & \multicolumn{4}{|c|}{ 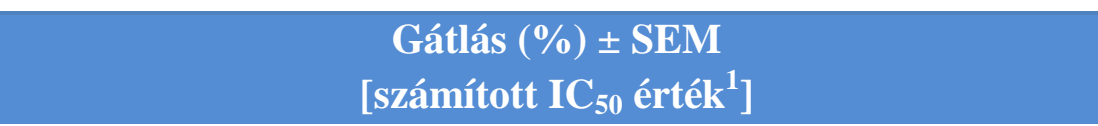 } \\
\hline & & Hela & MCF-7 & A2780 & A431 \\
\hline \multicolumn{6}{|c|}{$N$-acetil származékok } \\
\hline \multirow{2}{*}{$177 \mathbf{a}$} & 10 & -2 & - & - & $31,7 \pm 2,8$ \\
\hline & 30 & - & - & $26,5 \pm 1,0$ & $37,0 \pm 1,0$ \\
\hline \multirow{2}{*}{$180 \mathbf{a}$} & 10 & $50,9 \pm 2,4$ & $56,5 \pm 0,8$ & $45,5 \pm 0,4$ & $59,7 \pm 0,5$ \\
\hline & 30 & $54,2 \pm 2,2$ & $64,0 \pm 1,0$ & $61,1 \pm 0,8$ & $66,2 \pm 1,2$ \\
\hline \multirow{2}{*}{$177 b$} & 10 & $27,4 \pm 1,1$ & - & $39,5 \pm 2,1$ & $21,0 \pm 1,1$ \\
\hline & 30 & $97,4 \pm 0,1$ & $92,3 \pm 0,4$ & $96,3 \pm 0,2$ & $98,2 \pm 0,2$ \\
\hline \multirow{3}{*}{$180 b$} & 10 & $95,6 \pm 0,2$ & $93,2 \pm 0,6$ & $97,1 \pm 0,1$ & $96,7 \pm 0,2$ \\
\hline & 30 & $96,3 \pm 0,2$ & $92,3 \pm 0,3$ & $97,3 \pm 0,1$ & $96,3 \pm 0,3$ \\
\hline & & {$[1,3 \mu \mathrm{M}]$} & {$[1,3 \mu \mathrm{M}]$} & {$[1,1 \mu \mathrm{M}]$} & {$[1,3 \mu \mathrm{M}]$} \\
\hline \multicolumn{6}{|c|}{$N$-klóracetil származékok } \\
\hline \multirow{3}{*}{$178 \mathbf{a}$} & 10 & $38,7 \pm 2,2$ & $36,4 \pm 2,6$ & $94,6 \pm 0,6$ & $29,7 \pm 1,8$ \\
\hline & 30 & $95,8 \pm 0,3$ & $75,7 \pm 1,2$ & $96,6 \pm 0,3$ & $83,0 \pm 0,4$ \\
\hline & & & & {$[2,3 \mu \mathrm{M}]$} & \\
\hline \multirow{3}{*}{$181 a$} & 10 & $95,8 \pm 0,4$ & $57,2 \pm 2,7$ & $96,5 \pm 0,1$ & $90,4 \pm 0,4$ \\
\hline & 30 & $96,2 \pm 0,2$ & $86,7 \pm 0,9$ & $97,5 \pm 0,1$ & $95,9 \pm 0,2$ \\
\hline & & {$[1,6 \mu \mathrm{M}]$} & {$[8,3 \mu \mathrm{M}]$} & {$[0,8 \mu \mathrm{M}]$} & {$[5,1 \mu \mathrm{M}]$} \\
\hline \multirow{3}{*}{$178 b$} & 10 & $22,0 \pm 0,9$ & - & $77,1 \pm 0,9$ & $25,6 \pm 1,4$ \\
\hline & 30 & $90,7 \pm 1,1$ & $75,6 \pm 1,6$ & $97,1 \pm 0,1$ & $89,6 \pm 1,0$ \\
\hline & & & & {$[6,8 \mu \mathrm{M}]$} & {$[12,3 \mu \mathrm{M}]$} \\
\hline \multirow{3}{*}{$181 b$} & 10 & $96,8 \pm 0,1$ & $93,1 \pm 0,6$ & $94,2 \pm 0,6$ & $98,1 \pm 0,2$ \\
\hline & 30 & $97,4 \pm 0,2$ & $94,5 \pm 0,5$ & $94,1 \pm 0,6$ & $98,6 \pm 0,2$ \\
\hline & & {$[5,8 \mu \mathrm{M}]$} & {$[2,6 \mu \mathrm{M}]$} & {$[2,1 \mu \mathrm{M}]$} & {$[3,9 \mu \mathrm{M}]$} \\
\hline \multirow{3}{*}{$178 c$} & 10 & - & $63,8 \pm 1,0$ & $85,5 \pm 1,1$ & $84,0 \pm 1,1$ \\
\hline & 30 & $97,4 \pm 0,2$ & $93,1 \pm 0,2$ & $94,2 \pm 0,4$ & $98,5 \pm 0,3$ \\
\hline & & & {$[7,3 \mu \mathrm{M}]$} & {$[8,0 \mu \mathrm{M}]$} & {$[8,8 \mu \mathrm{M}]$} \\
\hline \multirow{3}{*}{$181 c$} & 10 & $28,0 \pm 3,0$ & $30,2 \pm 0,8$ & $94,7 \pm 0,2$ & $96,2 \pm 0,1$ \\
\hline & 30 & $97,3 \pm 0,1$ & $93,7 \pm 0,3$ & $92,5 \pm 0,2$ & $98,5 \pm 0,1$ \\
\hline & & & & {$[1,6 \mu \mathrm{M}]$} & {$[1,8 \mu \mathrm{M}]$} \\
\hline \multicolumn{6}{|c|}{$N$-benzoil származékok } \\
\hline \multirow{2}{*}{ 179a } & 10 & - & - & - & - \\
\hline & 30 & - & - & $38,2 \pm 1,5$ & - \\
\hline \multirow{2}{*}{$182 a$} & 10 & $43,3 \pm 0,7$ & - & $75,1 \pm 0,8$ & $46,6 \pm 0,9$ \\
\hline & 30 & $88,0 \pm 1,5$ & $65,4 \pm 0,6$ & $95,0 \pm 0,8$ & $60,8 \pm 2,8$ \\
\hline
\end{tabular}




\begin{tabular}{|c|c|c|c|c|c|}
\hline & & {$[19,1 \mu \mathrm{M}]$} & & {$[7,9 \mu \mathrm{M}]$} & {$[9,2 \mu \mathrm{M}]$} \\
\hline \multirow{2}{*}{$\mathbf{1 7 9 b}$} & 10 & - & - & $27,1 \pm 2,4$ & - \\
\cline { 2 - 6 } & 30 & $53,6 \pm 2,0$ & $29,2 \pm 1,4$ & $43,4 \pm 1,6$ & $22,6 \pm 1,5$ \\
\hline \multirow{2}{*}{$\mathbf{1 8 2 b}$} & 10 & - & - & $32,8 \pm 2,2$ & - \\
\cline { 2 - 6 } & 30 & $92,5 \pm 0,7$ & $24,5 \pm 0,5$ & $50,9 \pm 0,6$ & $27,0 \pm 2,5$ \\
\hline \multirow{2}{*}{ Cisplatin } & 10 & $42,6 \pm 2,3$ & $53,0 \pm 2,3$ & $83,6 \pm 1,2$ & $88,6 \pm 0,5$ \\
\cline { 2 - 6 } & 30 & $99,9 \pm 0,3$ & $86,9 \pm 1,3$ & $95,0 \pm 0,3$ & $90,2 \pm 1,8$ \\
\hline
\end{tabular}

${ }^{1}$ Középértéke a két különböző, egymástól független, 5 párhuzamos csatornával végrehajtott meghatározásnak, a standard deviáció kisebb, mint $15 \%$

${ }^{2}<20 \%$ gátlás \% értékeket nem tüntettük fel, a könnyebb áttekinthetőség érdekében

7. táblázat: A Prins-Ritter reakcióval előállított D-homoszteroidok (177-182) antiproliferatív aktivitása

Két potens vegyület $(\mathbf{1 8 0 b}, \mathbf{1 8 1 a})$ tumorszelektivitását teszteltük MTT-módszer segítségével, intakt humán fibroblaszt sejteken (MRC-5). A 180b dózisfüggő módon, kisebb mértékben gátolta az MRC-5 sejtek osztódását (8. táblázat), mint a $\mathbf{1 8 1 b}$ vagy a referenciavegyület (ciszplatin). A 7. és a 8. táblázatban látható gátlás \%-ok alapján elmondható, hogy míg a 180b jelü származék tumorszelektív, addig az $N$-klóracetil származék (181a) mind a tumorsejtvonalakra, mind az intakt sejtekre nézve toxikus.

\begin{tabular}{|c|c|c|c|}
\hline \multirow{2}{*}{ Vegyïlet } & \multicolumn{3}{|c|}{ Gátlás $(\%) \pm$ SEM } \\
\cline { 2 - 4 } & $\mathbf{1} \boldsymbol{M} \mathbf{M}$ & $\mathbf{3} \boldsymbol{\mu M}$ & $\mathbf{1 0} \boldsymbol{\mu M}$ \\
\hline $\mathbf{1 8 0 b}$ & $14,0 \pm 1,4$ & $16,4 \pm 1,1$ & $89,4 \pm 0,2$ \\
\hline 181a & $89,9 \pm 0,8$ & $89,7 \pm 0,7$ & $89,7 \pm 1,0$ \\
\hline ciszplatin & $22,8 \pm 1,5$ & $33,0 \pm 0,5$ & $73,0 \pm 1,9$ \\
\hline
\end{tabular}

8. táblázat: A két legpotensebb vegyület $(\mathbf{1 8 0 b}, \mathbf{1 8 1 a})$ sejtosztódás-gátlása (\%) MRC-5 sejteken

Kutatómunkánk folytatásában a 180b antiproliferatív hatását vizsgáltuk további három emlőkarcinóma sejtvonalon (9. táblázat). Ezek különböző receptorokat fejeznek ki: T-47D (ösztrogén, progeszteron és androgén receptort), MDA-MB-361 (ösztrogén receptort és HER2-t). Az MDA-MB-231 nem fejez ki ösztrogén, progeszteron és HER-2 receptort. Megfigyeltük, hogy a $\mathbf{1 8 0 b}$ nem mutatott jelentős hatásbeli különbségeket az eltérő 
emlökarcinóma sejtvonalakon, így feltételezzük, hogy hormonreceptor-független módon fejti ki antitumor aktivitását.

\begin{tabular}{|c|c|c|c|c|}
\hline \multicolumn{5}{|c|}{ 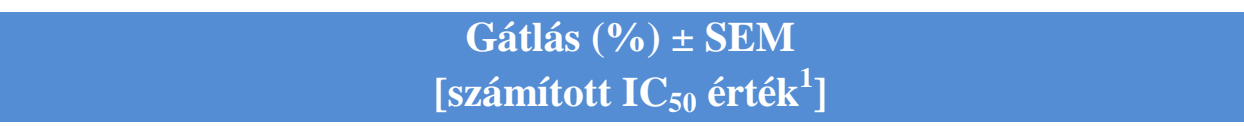 } \\
\hline Vegyület & $\begin{array}{l}\text { Konc. } \\
(\mu \mathrm{M})\end{array}$ & $\mathrm{T}-47 \mathrm{D}$ & MDA-MB-361 & MDA-MB-231 \\
\hline \multirow{3}{*}{$180 b$} & 10 & $94.6 \pm 0.7$ & $89.7 \pm 0.3$ & $95.3 \pm 0.2$ \\
\hline & 30 & $95.7 \pm 0.5$ & $90.7 \pm 0.4$ & $95.5 \pm 0.1$ \\
\hline & & {$[3.6 \mu \mathrm{M}]$} & {$[2.9 \mu \mathrm{M}]$} & {$[5.0 \mu \mathrm{M}]$} \\
\hline
\end{tabular}

${ }^{1}$ Középértéke a két különböző, egymástól független, 5 párhuzamos csatornával végrehajtott meghatározásnak, a standard deviáció kisebb, mint 15\%

12. táblázat: A 180b sejtosztódás gátló hatása a különböző emlőkarcinóma sejtvonalakon

Kutatásunk folytatásában további vizsgálatokat végeztünk a $\mathbf{1 8 0 b}$ antiproliferatív hatásmechanizmusára vonatkozóan. Áramlási citometriás módszerrel, sejtciklus analízist hajtottunk végre a 180b jelü vegyület $3 \mu \mathrm{M}$ és $10 \mu \mathrm{M}$ koncentrációjú oldatával kezelt A2780as sejteken (65. ábra). 24 illetve 48 órás inkubációs idő után mindkét esetben a hipodiploid (subG1) populáció koncentráció-függő növekedését tapasztaltuk, amely az apoptótikus sejthalálra utalt. 24 órás kezelést követően a G1 fázisban lévő sejtek mennyisége szignifikánsan nőtt a szintézis fázis (S) rovására, amelyet a sejtciklus esetleges G1-S blokádja eredményezett. Hosszabb expozíciós idő után (48 óra) azonban a sejtek G2/M fázisban halmozódtak fel, amely utal a G2/M blokádjára. A tubulin polimerizáció és így a mitotikus orsó képződésének zavara okozhatja a G2/M fázisban történő sejtciklus gátlást. Mindezeket összevetve feltételezhető, hogy a kezelés időtartama a meghatározó az A2780-as sejtek eloszlásában. Megfigyeltük, hogy a kontroll értékekhez viszonyítva a nagyobb koncentrációnál (10 $\mu \mathrm{M})$ markánsabb volt a sejtciklus zavara, ezáltal a sejteloszlás. 

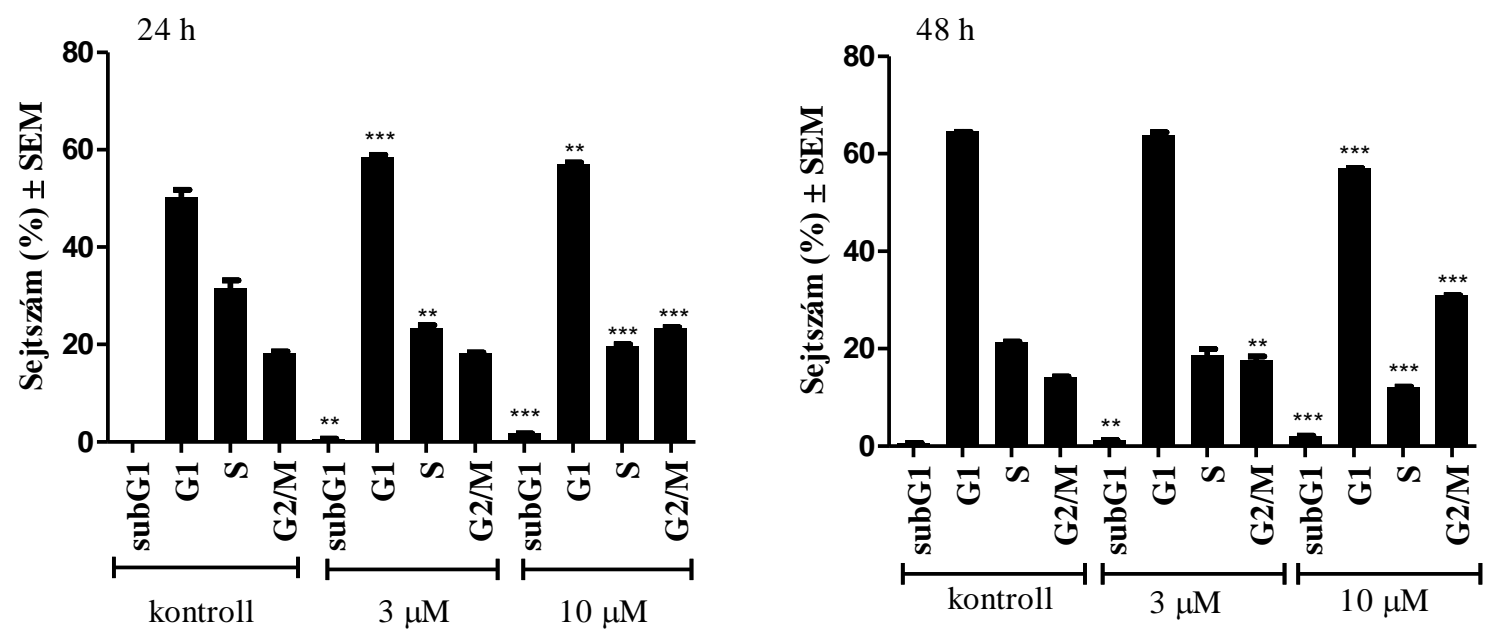

65. ábra:A 180b jelü vegyület sejtciklus analízise 24 órás (bal oldali oszlopdiagram) illetve 48 órás (jobb oldali oszlopdiagram) inkubációs idő után, A2780-as sejteken. A szignifikancia értékek a kontrollhoz viszonyítva: $* *-p<0,01, * * *-p<0,001$

Az irodalomban számos példa látható olyan tumorellenes szerekre, amelyek a tubulin fehérje polimerizációjának gátlásán keresztül fejtik ki antitumor hatásukat. ${ }^{3,10,115,116}$ Néhány 2-es helyzetben szubsztituált ösztron származék is hasonló hatásmechanizmust mutat. A mitózis megakadályozható azonban olyan szerek alkalmazásával is, amelyek a tubulin polimerizációját gyorsítva hoznak létre rendellenes mikrotubulus-hálózatot. Tanszékünk Szteroidkémiai Kutatócsoportja nemrégiben állított elő egy olyan D-szekoösztron 3-benzilétert, amely az utóbbi módon gátolja in vitro a sejtosztódást. ${ }^{117}$ Mivel az általunk jelen munkában előállított dihidrooxazin (180b) a sejtciklus G2/M blokádját okozza, így megvizsgáltuk annak a tubulin fehérje polimerizációjának sebességére gyakorolt direkt hatását egy sejtmentes in vitro rendszerben. A kísérleti eljárás a mikrotubulusok fényszórásán alapul, amely arányos a kísérlet során képződő mikrotubulus polimer koncentrációjával. A folyamat során abszorbanciát mérünk (340 nm hullámhosszon), és az abszorbancia változásából következtetünk a tubulin polimerizációjának maximális sebességére (a tubulin 85-90\%-a polimerizálódik és maximális OD (optikai denzitás) értéket ér el). A folyamat számszerüsítésére az idő függvényében ábrázoltuk a mért abszorbanciát és $V_{\max }(\Delta \mathrm{OD} / \mathrm{min})$ értékeket számoltunk. Megfigyeltük, hogy a tesztanyag (180b) a választott 50 és $100 \mu \mathrm{M}$-os koncentrációnál is fokozza a tubulin polimerizációjának sebességét, hasonlóan, mint a referenciavegyületként használt paklitaxel (66. ábra, felső ábra). Ezen eredményekből 
megállapítható, hogy a $\mathbf{1 8 0 b}$ in vitro képes rendellenes mikrotubulus hálót kialakítani, és ezáltal gátolni a tumorsejtek osztódását.
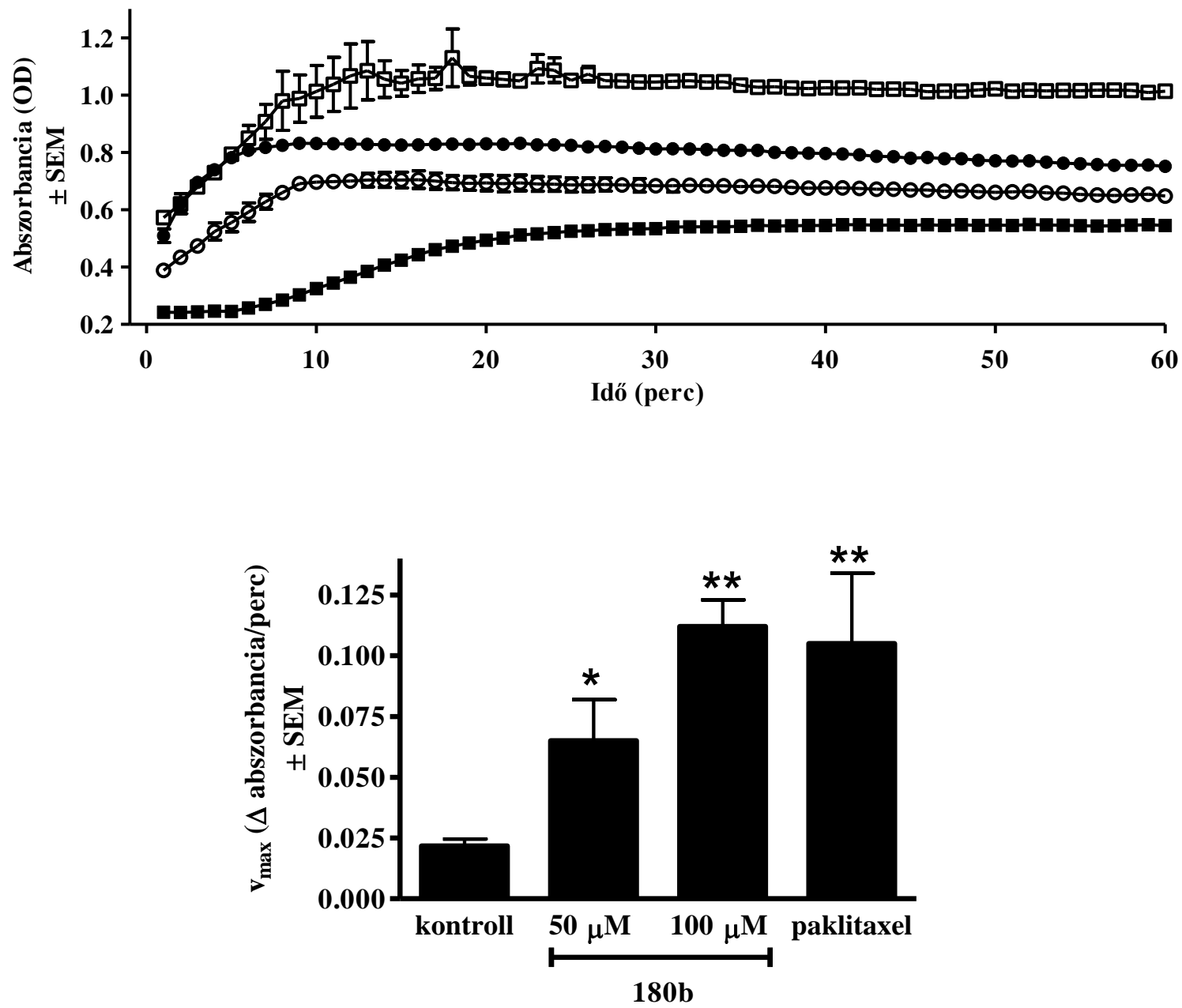

66. ábra: A 180b jelű vegyület tubulin polimerizációra gyakorolt hatása. Felső ábra: kinetikai görbék: ஐ: kontroll, ○: a 180b jelü vegyület $50 \mu \mathrm{M}$-os oldata, •: a 180b jelü vegyület 100 $\mu \mathrm{M}$-os oldata, $\square$ : paklitaxel $(10 \mu \mathrm{M})$. Alsó ábra: a tubulin polimerizációjának számított maximális sebessége $\left(\mathrm{V}_{\mathrm{max}}\right)$. Minden oszlop átlagot jelöl \pm SEM, $\mathrm{n}=3$. A szignifikancia értékek a kontrollhoz viszonyítva: * $-p<0,05, * *-p<0,01$ 


\section{KÍSÉRLETI RÉSZ}

\section{1. Általános kísérleti rész}

\subsubsection{Kémiai rész}

Az olvadáspontokat Kofler-blokkon mértük, korrekció nélkül. Az elemanalízist Perkin-Elmer CHN 2400-es modellel hajtottuk végre. A reakciók lefutását vékonyréteg-kromatográfiával követtük: szilikagél $60 \mathrm{~F}_{254}$; vastagsága 0,2 mm (Merck); az elöhívást jóddal és UV-vel (365 nm) végeztük, melyet $5 \%$ foszformolibdénsav 50\% vizes foszforsavas elegyével való lefújás, majd azt követő 10 perces $100-120^{\circ} \mathrm{C}$-on történő melegítés elözött meg. Az $\mathrm{R}_{\mathrm{f}}$-értékeket a következő oldószer-rendszerekben határoztuk meg: (A) $\mathrm{CH}_{2} \mathrm{Cl}_{2}$, (B) $2 \%$ EtOAc/ $\mathrm{CH}_{2} \mathrm{Cl}_{2}$, (C) 1:1 terc-butil-metil-éter/hexán, (D) EtOAc, (E) 30\% EtOAc/hexán, (F) 10\% MeOH/EtOAc, (G) $50 \% \mathrm{EtOAc} / \mathrm{CH}_{2} \mathrm{Cl}_{2}$, (H) $20 \% \mathrm{EtOAc} / \mathrm{CH}_{2} \mathrm{Cl}_{2}$. A reakciótermékek elválasztása, illetve tisztítása 40-63 $\mu \mathrm{m}$ szemcseméretü Kieselgel 60 (MERCK) álló fázissal töltött oszlopon történt. A mikrohullámú reakciókat CEM Discover SP készülékkel végeztük. Az ${ }^{1} \mathrm{H}-\mathrm{NMR}$ spektrumok felvétele Bruker DRX-500 készülékkel történt 500 MHz-en, belső standardként $\mathrm{Me}_{4} \mathrm{Si}$-t, oldószerként pedig $\mathrm{CDCl}_{3}$-ot használva (az egyéb oldószereket a megfelelő adatoknál jelöltük). ${ }^{13} \mathrm{C}$-NMR spektrumok felvétele ugyanezen a készüléken történt $125 \mathrm{MHz}$ en, azonos körülmények között. A tömegspektrometriás vizsgálatokhoz a szteroid minták és a mátrixként alkalmazott telített $\mathrm{C}_{70}$ fullerén oldat (oldószer: toluol) 1-1 $\mu$ l-ét mintatartó tálcára (MTP 384 target plate ground steel TF, Bruker Daltonics, Bremen, Germany) csepegtettük. A minták beszáradása után az elemzéseket Bruker Autoflex II típusú mátrix-segítette lézerdeszorpciós ionizációs technikát alkalmazó repülési idő analizátoros (MALDI TOF/TOF) tömegspektrométerrel, reflektor detektálási módban végezték el. Az ionizáláshoz 337 nm-es nitrogén lézert alkalmaztak, a vizsgálatok során 500 lövés tömegspektrumát összesítették, a lézer frekvenciája $50 \mathrm{~Hz}$ volt. EI-MS tömegspektrométerrel is végeztünk méréseket (Varian MAT 311A készüléken). A tömegspektrumokat pozitív és negatív ionizációs módban, 50 és $1200 \mathrm{~m} / \mathrm{z}$ tartományban egyaránt regisztrálták, a gyorsító feszültség $20 \mathrm{kV}$, a késleltetési idő 80 ns volt. 


\subsubsection{Gyógyszerhatástani vizsgálatok}

\subsubsection{A sejtkultúrák és az antiproliferatív vizsgálatok}

A szteroidok antiproliferatív hatását kolorimetriás MTT-módszerrel in vitro teszteltük tumorsejtvonalakon (Hela - méhnyak karcinóma, MCF-7 - emlő karcinóma, A431 bőrlaphám karcinómába, A2780 - petefészek karcinóma) és intakt fibroblaszt sejtvonalon (MRC-5 és HFF), amelyeket a European Collection of Cell Cultures (Sailsbury, UK) által szereztünk be. A 180b jelű vegyületet további emlőkarcinóma sejteken is teszteltük: T-47D (ösztrogén és progeszteron receptorokat fejez ki, HER-2 overexpresszió, ösztrogén-függő sejtosztódás); MDA-MB-361 (ösztrogén receptort fejez ki, HER-2 overexpresszió); MDAMB-231 (háromszorosan negatív sejtvonal). A sejteket müanyag flaskában tenyésztettük optimális körülmények között, $37{ }^{\circ} \mathrm{C}$-on, $5 \%$-os $\mathrm{CO}_{2}$ atmoszféra mellett. A sejteket $10 \%$ borjúszérumot (FBS), $1 \%$ nem esszenciális aminosavakat és $1 \%$ antibiotikum-antimikotikum keverékét (AAM) tartalmazó minimális esszenciális médiumban növesztettük, az A2780-as sejteket pedig RPMI médiumban tartottuk, amely 10\% FBS-ot, 1\% AAM-ot, és 1\% Lglutamint tartalmazott. Az alkalmazott mediumok és a hozzáadott anyagok a Life Technologies (Paisley, Scotland, UK), a vegyszerek pedig a Sigma-Aldrich Kft. (Budapest, Magyarország) termékei. A vizsgálathoz a sejteket 96 lyukú mikrotiter lemezre telepítettük, 5000/lyuk koncentrációban.

A vegyületeket dimetil-szulfoxidban (DMSO) oldva, $10 \mathrm{mM}$-os törzsoldatokat készítettünk. Az antiproliferatív vizsgálat során a legmagasabb koncentrációban alkalmazott $(0,3 \%)$ dimetil-szulfoxid mennyisége sem befolyásolta jelentősen a sejtek proliferációját. 24 óra után a kitelepített sejteket a tesztanyagok különböző koncentrációival $(0,03 \mu \mathrm{M}, 0,1 \mu \mathrm{M}$, $0,3 \mu \mathrm{M}, 1 \mu \mathrm{M}, 3 \mu \mathrm{M}, 10 \mu \mathrm{M}, 30 \mu \mathrm{M})$ kezeltük, majd 72 órán át inkubáltuk $\left(37^{\circ} \mathrm{C}, 5 \% \mathrm{CO}_{2}\right)$. Az inkubációs idő lejárta után $20 \mu \mathrm{MTT}$ ([3-(4,5-dimetiltiazol-2-il)-2,5-difeniltetrazoliumbromid]) oldatot $(5 \mathrm{mg} / \mathrm{ml})$ adtunk lyukanként a lemezre, az MTT-t az intakt sejtek mitokondriális enzimei színes formazán kristállyá redukálták. A kristályokat dimetilszulfoxidban oldottuk, és a fotometriás meghatározást 545 nm-en Elisa spektrofotométerrel végeztük. ${ }^{37}$ Két független mérést hajtottunk végre, 5-5 párhuzamossal. Referenciaként a ciszplatint alkalmaztuk, amely a nőgyógyászati gyakorlatban régóta alkalmazott antitumor vegyület. 
A vizsgálatokban kapott abszorbancia értékek fordítottan arányosak a tesztanyagok sejtosztódás gátló hatásával. A $10 \mu \mathrm{M}$-os koncentrációban legalább 50\%-os gátló hatással rendelkező vegyületek tekinthetők hatékony antiproliferatív anyagoknak. Egy koncentrációsort alkalmazva felvettuik ezen származékok dózis-hatás görbéit, és meghatároztuk a számított IC $_{50}$ értéküket, amely megmutatja a maximális gátlás feléhez tartozó koncentrációt. $\mathrm{Az} \mathrm{IC}_{50}$ értékek számítását és a statisztikus analízist (ANOVA) a GraphPadPrism 5.0 (GraphPad Software; San Diego, CA, USA) programmal végeztük.

\subsubsection{A sejtciklus analizis és az áramlásos citometria}

A sejtek DNS tartalmának meghatározását áramlási citometriás analízissel hajtottuk végre. A módszer alapja, hogy a vizsgálni kívánt sejtrészeket, esetünkben a DNS állományt, fluoreszcens jelzőanyaggal (propídium-jodiddal) jelöltük, és ennek a fluoreszcenciáját mértük áramlási citometria segítségével. A fluoreszcencia intenzitása és a fényszórás mértéke jellemző a sejt alakjára és méretére, így a módszer alkalmas egyedi sejtek meghatározására. ${ }^{118}$

Az analízishez a sejteket kitelepítettük egy hatlyukú lemezre (250.000/lyuk), 24 óra elteltével a szteroidok különböző koncentrációival ( $1 \mu \mathrm{M}, 3 \mu \mathrm{M}, 10 \mu \mathrm{M}, 30 \mu \mathrm{M})$ kezeltük, majd 24 órás vagy 48 órás inkubáció után a mediumot eltávolítottuk. A sejteket kétszer átmostuk hideg foszfátpufferrel (PBS), és tripszinnel 2-3 percig kezeltük. A képződött sejtszuszpenziót centrifugáltuk (1500 rpm, 10 perc, $\left.4{ }^{\circ} \mathrm{C}\right)$, a sejteket $1 \mathrm{ml}$ hideg PBS-sel mostuk, majd ismét centrifugáltuk (1500 rpm, 10 perc, $\left.4{ }^{\circ} \mathrm{C}\right)$. Az így képződő pelleteket $70 \%$ os etanolban fixáltuk, és a mintákat a mérésig $-20^{\circ} \mathrm{C}$-on tartottuk.

A mérés napján a mintákat ismét centrifugáltuk (1500 rpm, 10 perc, $\left.4{ }^{\circ} \mathrm{C}\right)$, a felülúszó leszívása után a DNS-t festettük $(10 \mu \mathrm{g} / \mathrm{ml})$. A festékoldat $1,0 \mathrm{mg} / \mathrm{ml} \mathrm{Na-citrátot,} 3 \mu \mathrm{l} / \mathrm{ml}$ TritonX 100-at, 1,0 mg/ml propídium-jodidot, és $0,02 \mathrm{mg} / \mathrm{ml}$ ribonukleáz-A-t tartalmazott, desztillált vízben oldva. A Na-citrátot pufferként alkalmaztuk, a TritonX pedig a membrán átjárhatóságát segítette elő, így a propídium-jodid képes a DNS-hez kötődni. A mintákat 60 percig sötétben inkubáltuk. Azt követően ismét centrifugáltuk (1500 rpm, 10 perc, $\left.4{ }^{\circ} \mathrm{C}\right)$, és 1 ml PBS-sel mostuk, a mintákat reakciócsövekbe helyeztük, majd áramlási citometriás analízissel (CyFLow-Partec GmbH, Münster, Germany) meghatároztuk a sejtek DNS tartalmát. A mérés során kapott hisztogram a sejtek százalékos eloszlását mutatta a sejtciklus különböző fázisaiban (subG1, G1, S és G2/M). A hisztogramokat egyenként értékeltük, és a 
sejtek százalékos arányait a ModFit LT program (Verity Software House, Topsham, ME, USA) segítségével határoztuk meg.

\subsubsection{Tubulin polimerizációs assay}

A 180b jelủ származék tubulin polimerizációra kifejtett hatását in vitro tubulin polimerizációs kit (Tebu-bio, Le Perry-en-Yvelines, Franciaország) segítségével vizsgáltuk. A 96 lyukú UVáteresztő mikrotiter lemezt $37{ }^{\circ} \mathrm{C}$-ra előmelegítettük, majd felvittünk rá a tesztanyagunk (180b) $50 \mu \mathrm{M}$-os és $100 \mu \mathrm{M}$-os oldatából 10-10 $\mu$ l-t. Negatív kontrollként a kitben megtalálható General Puffer $10 \mu$ l-ét, pozitív kontrollként pedig a $10 \mu \mathrm{M}$ koncentrációjú paklitaxel törzsoldat $10 \mu$ l-ét használtuk. Ezután elindítottuk a reakciót a kitben található Tubulin Polimerizációs Pufferrel (100 $\mu 1$ 3,0 mg/ml tubulin 80 mM PIPES-ben 6,9-es pH-n, 2 $\mathrm{mM} \mathrm{MgCl}_{2}$, 0,5 mM EGTA, $1 \mathrm{mM}$ GTP, 10,2\% glicerint adtunk minden egyes mintához). A mérést $37{ }^{\circ} \mathrm{C}$-on, $340 \mathrm{~nm}$ hullámhosszon végeztük, 60 cikluson (percenként mérve, mérések között rázva) keresztül, SPECTROStar Nano (BMG Labtech, Offenburg, Germany) fotométerrel. Az így kapott eredményekből felvettük a tubulin polimerizációs görbéket, amelyek az optikai denzitást mutatják az idő függvényében. Meghatároztuk a reakció maximális sebességét ( $\mathrm{V}_{\max }: \Delta$ abszorbancia/perc). A különböző abszorbanciaértékeket két egymást követő időpontban határoztuk meg, és a legnagyobb abszorbanciakülönbség szolgáltatta a tesztanyagunk (180b) $\mathrm{V}_{\max }$ értékét a tubulin polimerizációs reakcióban. $\mathrm{A} \mathrm{V}_{\max }$ értékét párosítatlan $t$-próbával álapítottuk meg, Prism 5 software segítségével. A tesztanyagunk (180b) $\mathrm{V}_{\max }$ értékét a kezeletlen kontrollként használt sebességértékekkel hasonlítottuk össze. 


\subsection{Részletes kísérleti rész}

5.2.1. A 13a-D-szekooxim (135), a dimetil-acetál (136) és az izoxazolidin származékok (137-139) elóállítása

\subsubsection{A 13a-D-szekooxim (135) és a dimetil-acetál (136) elöállítása}

A módszer: A D-szekoaldehidet 102 (900 mg, 3,00 mmol) és a hidroxilamin-hidrokloridot (210 mg, 3,00 mmol) metanolban oldottuk (10 ml), majd hozzáadtuk a nátrium-hidroxid (500 mg) metanolos oldatát $(10 \mathrm{ml})$. Az elegyet 1 órán keresztül kevertük, vízre öntöttuik, majd hígított (10\%) sósavval semlegesítettük. Diklórmetános extrakció után a szerves fázist vízmentes $\mathrm{Na}_{2} \mathrm{SO}_{4}$-on szárítottuk, az oldószert bepároltuk. A terméket oszlopkromatográfiásan tisztítottuk, diklórmetán eluenssel. A kromatográfia során nyert első anyag a dimetil-acetál volt (136), az elválasztást tovább folytatva kaptuk a szekooximot (135). B módszer: A D-szekoaldehidet $(\mathbf{1 0 2}, 300 \mathrm{mg}, 1,00 \mathrm{mmol})$ acetonitrilben $(10 \mathrm{ml})$ oldottuk, majd hidroxilamin-hidrokloridot $(70 \mathrm{mg}, 1,00 \mathrm{mmol})$ és nátrium-acetátot $(250 \mathrm{mg}, 3,00$ mmol) adtunk hozzá. A reakcióelegyet 6 órán keresztül szobahőmérsékleten kevertük, majd vízre öntöttük, hígított (10\%-os) sósavval semlegesítettük, végül diklórmetánnal extraháltuk. A szerves fázist vízmentes $\mathrm{Na}_{2} \mathrm{SO}_{4}$-on szárítottuk, az oldószert bepároltuk. A terméket (135) oszlopkromatográfia során, diklórmetán eluenssel, 80\%-os hozammal nyertük.

\subsubsection{Az izoxazolidin sztereoizomerek $(137,138)$ elóállitása}

Az oximot (135, $200 \mathrm{mg}, 0,64 \mathrm{mmol})$ toluolban $(5 \mathrm{ml})$ oldottuk, és a $\mathrm{BF}_{3} \cdot \mathrm{OEt}_{2}$ (48\%-os oldat, 0,5 ml) toluolos oldatát $(5 \mathrm{ml})$ cseppenként adagoltuk hozzá. 3 órán át forraltuk $\mathrm{N}_{2}$ atmoszférában, vízzel mostuk, vízmentes $\mathrm{Na}_{2} \mathrm{SO}_{4}$-on szárítottuk, majd az oldószert bepároltuk. A terméket oszlopkromatográfiásan tisztítottuk, 2:8 arányú terc-butil-metiléter/hexán eluenssel. Az elválasztás során nyert első anyag a 137-es, a kromatográfiát tovább folytatva izoláltuk a 138-as anyagot.

\subsubsection{Az N-metil-izoxazolidin (139) elöállitása}

A D-szekoaldehidet $(\mathbf{1 0 2}, 300 \mathrm{mg}, 1,00 \mathrm{mmol})$ metanolban $(10 \mathrm{ml})$ oldottuk, $N$ metilhidroxilamin-hidrokloridot $(150 \mathrm{mg}, 1,80 \mathrm{mmol})$ és nátrium-acetátot $(250 \mathrm{mg}, 3,00$ mmol) adtunk hozzá. A reakcióelegyet 6 órán keresztül forraltuk, szobahőmérsékletüre hütöttük, vízre öntöttük, hígított sósavval (10\%-os) semlegesítettük, végül diklórmetánnal extraháltuk. A szerves fázist vízmentes $\mathrm{Na}_{2} \mathrm{SO}_{4}$-on szárítottuk és az oldószert bepároltuk. A 
terméket oszlopkromatográfiásan tisztítottuk, 1:9 arányú etil-acetát/diklórmetán eluenssel. A kromatográfia során nyertük az $N$-metil-izoxazolidint (139).

I. Összefoglaló táblázat

A vegyületek fizikai adatai.

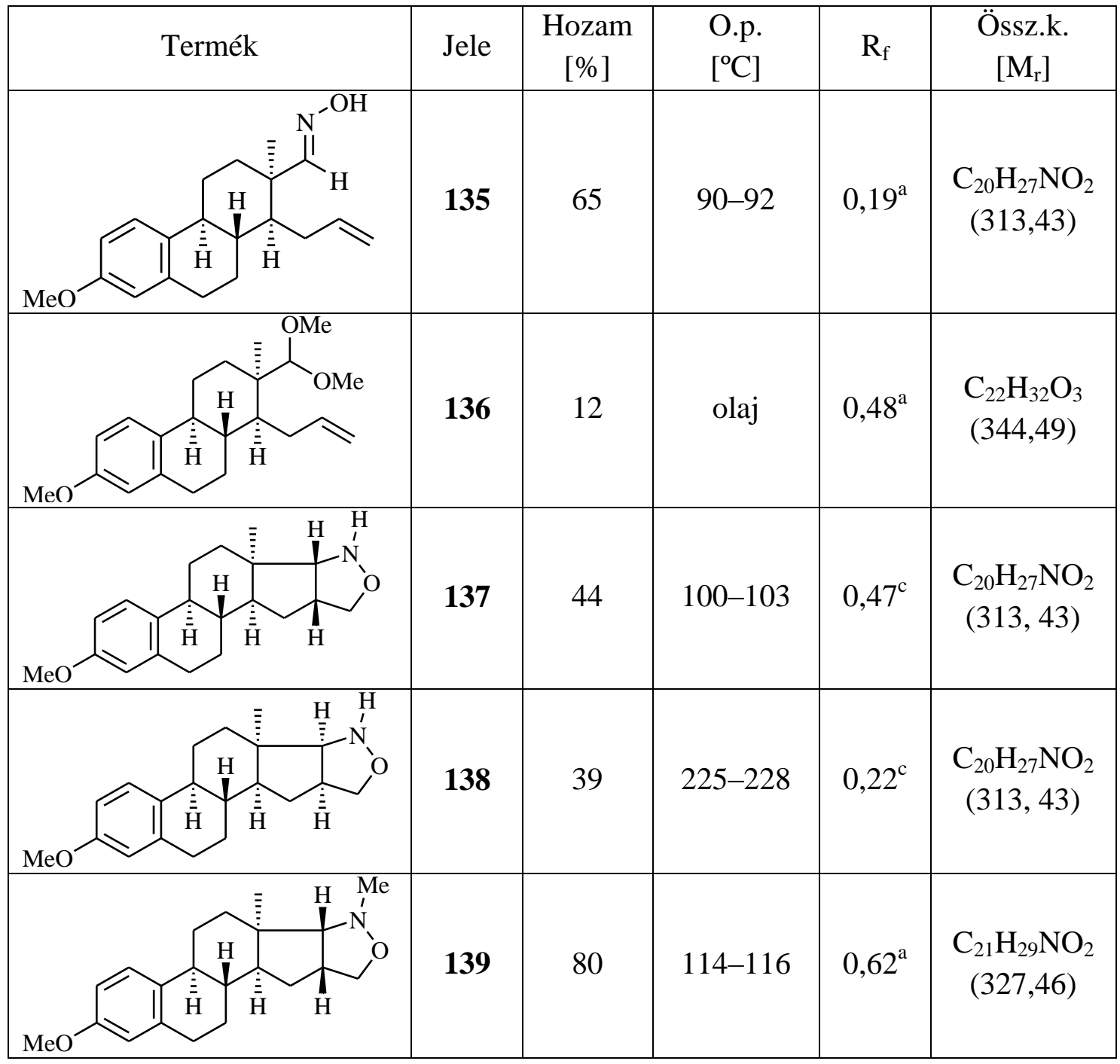




\subsubsection{Cikloadduktumok (145, 146) elóállítása a szekooximokból $(67,135)$}

\subsubsection{A brómozott cikloadduktumok elóállítása (145a, 146a, 148)}

Általános szintézismódszer

Az oximot (67 vagy 135; $200 \mathrm{mg}, 0,66 \mathrm{mmol}$ ) diklórmetánban (10 ml) oldottuk, és $N$ brómszukcinimidet (120 mg, 0,66 mmol) adtunk hozzá. A reakcióelegyet szobahőmérsékleten 30 percig kevertük, majd az oldószert bepároltuk. A maradékot toluolban (10 ml) oldottuk, és $N$-fenilmaleimidet $(\mathbf{1 4 4}, 116 \mathrm{mg}, 0,66 \mathrm{mmol})$ adtunk hozzá. Az oldatot 2 órán keresztül 50 ${ }^{\circ} \mathrm{C}$-on kevertük, majd az oldószert bepároltuk.

\subsection{A 145a cikloadduktum elóállítása}

Az „Általános szintézismódszernél” ismertetett leírás alapján elvégeztük a megfelelő oxim (135) átalakítását, majd kromatográfiás tisztítás során, 3:7 arányú terc-butil-metil-éter/hexán eluenst alkalmazva nyertük a $\mathbf{1 4 5 a}$ cikloadduktumot.

\subsection{A 146a cikloadduktum elóállítása}

Az „Általános szintézismódszernél” ismertetett leírás alapján elvégeztük a megfelelő oxim (67) átalakítását, majd kromatográfiás tisztítás során, 3:7 arányú terc-butil-metil-éter/hexán eluenst alkalmazva nyertük a 146a cikloadduktumot.

\subsection{A 148 dimer elöállítása}

Az oximot 67 (200 mg, 0,66 mmol) diklórmetánban $(10 \mathrm{ml})$ oldottuk, és $\mathrm{N}$ brómszukcinimidet (120 mg, 0,66 mmol) adtunk hozzá. A reakcióelegyet szobahőmérsékleten 30 percig kevertük, majd a kiváló csapadékot (148) szürtük, és hideg acetonitrillel mostuk.

\subsubsection{A jódozott cikloadduktumok elöállítása $(145 b, 146 b)$}

\section{Általános szintézismódszer}

Az oximot (67 vagy 135; $200 \mathrm{mg}, 0,66 \mathrm{mmol})$ diklórmetánban $(10 \mathrm{ml})$ oldottuk, a reakcióelegyet jeges-vizes fürdőben hütöttük, majd 1 óra alatt adagoltuk hozzá kis részletekben az $N$-jódszukcinimidet $(150 \mathrm{mg}, 0,66 \mathrm{mmol})$. Az oldatot 30 percen keresztül szobahőmérsékleten kevertük, majd az oldószert bepároltuk. A maradékot toluolban (10 ml) 
oldottuk, és $N$-fenilmaleimidet $(\mathbf{1 4 4}, 116 \mathrm{mg}, 0,66 \mathrm{mmol})$ adtunk hozzá. Az elegyet 2 órán át $50{ }^{\circ} \mathrm{C}$-on kevertük, majd az oldószert bepároltuk.

\subsection{A $145 b$ cikloadduktum elóállítása}

Az „Általános szintézismódszernél” ismertetett leírás alapján elvégeztük a megfelelő oxim (135) átalakítását, majd kromatográfiás tisztítás során, 3:7 arányú terc-butil-metil-éter/hexán eluenst alkalmazva nyertük a $\mathbf{1 4 5 b}$ cikloadduktumot.

\subsection{A 146b cikloadduktum elöállítása}

$\mathrm{Az}$ „Általános szintézismódszernél” ismertetett leírás alapján elvégeztük a megfelelő oxim (67) átalakítását, majd kromatográfiás tisztítás során, 3:7 arányú terc-butil-metil-éter/hexán eluenst alkalmazva nyertük a 146b cikloadduktumot.

II. Összefoglaló táblázat

A vegyületek fizikai adatai.

\begin{tabular}{|l|c|c|c|c|c|}
\hline & Jele & $\begin{array}{c}\text { Hozam. } \\
{[\%]}\end{array}$ & $\begin{array}{c}\text { O.p. } \\
{\left[{ }^{\circ} \mathrm{C}\right]}\end{array}$ & $\mathrm{R}_{\mathrm{f}}$ & $\begin{array}{c}\text { Össz. } \mathrm{k} . \\
\left(\mathrm{M}_{\mathrm{r}}\right)\end{array}$ \\
\hline & $\mathbf{1 4 5 a}$ & 78 & $132-137$ & $0,33^{\mathrm{a}}$ & $\begin{array}{c}\mathrm{C}_{30} \mathrm{H}_{33} \mathrm{BrN}_{2} \mathrm{O}_{4} \\
(565,50)\end{array}$ \\
\hline
\end{tabular}




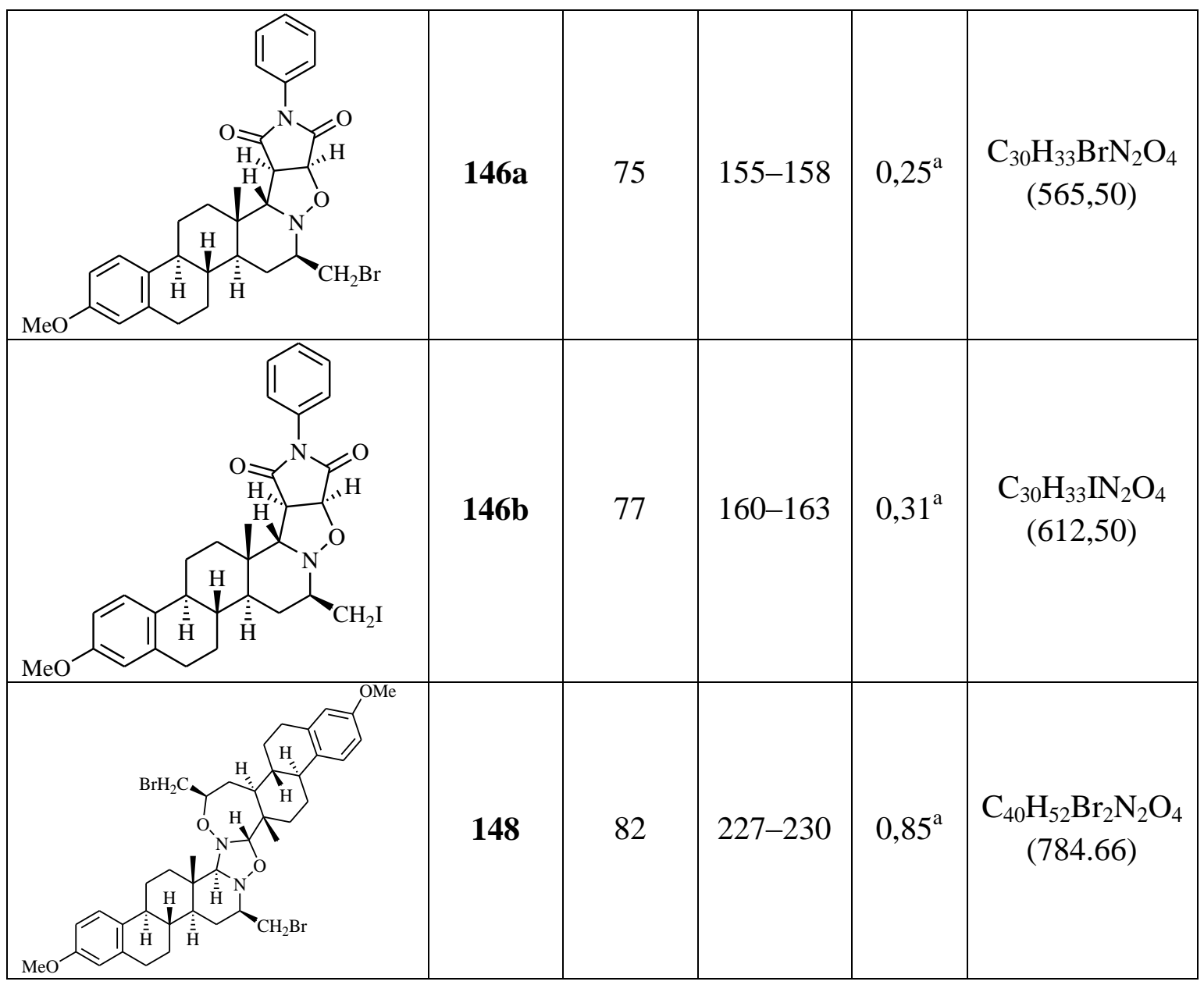

\subsubsection{Cikloadduktumok (153-158) elöállítása a szekooximokból $(67,149)$}

\section{Általános szintézismódszer}

A 67-es (157 mg, 0,50 mmol) vagy a 149-es oximot (195 g, 0,50 mmol) vízmentes acetonitrilben $(5 \mathrm{ml})$ oldottuk, az oldatot jeges-vizes fürdőben hütöttük, majd NBS-et $(0,50$ mmol) vagy NIS-et $(0,50 \mathrm{mmol})$ adagoltunk a reakcióelegyhez, $\mathrm{N}_{2}$ atmoszféra jelenlétében. 30 perces keverés után az oldószert bepároltuk, majd toluolt $(5 \mathrm{ml})$ és fenilizocianátot (52, 0,50 $\mathrm{mmol})$ vagy egy szubsztituált fenilizocianátot $(\mathbf{1 5 1}, \mathbf{1 5 2}, 0,50 \mathrm{mmol})$ adtunk hozzá. 


\section{A: Hagyományos melegítés}

A reakcióelegyet fenilizocianát (52) alkalmazásakor 3 órán át, 4-metoxifenil-izocianátnál (151) 0,5 órán át, míg 4-klórfenil-izocianátnál (152) 2 órán át forraltuk, majd szobahőmérsékletűre hütöttük, vízre öntöttük, és dietil-éterrel extraháltuk. A szerves fázist vízmentes $\mathrm{Na}_{2} \mathrm{SO}_{4}$-on szárítottuk, és bepároltuk. A terméket diklórmetán eluenssel oszlopkromatográfiásan tisztítottuk.

\section{B: Mikrohullámú besugárzás}

A reakcióelegyet nyomásálló edénybe helyeztük, majd $100{ }^{\circ} \mathrm{C}$-on mikrohullámú reaktorban 1 percig keverés mellett melegítettük. Ezután vízre öntöttük, majd dietil-éterrel extraháltuk. A szerves fázist vízmentes $\mathrm{Na}_{2} \mathrm{SO}_{4}$-on szárítottuk, és bepároltuk. A terméket diklórmetán eluenssel oszlopkromatográfiásan tisztítottuk.

\subsubsection{A 16-brómmetil-nitron (142a vagy 150a) reakciója fenil-izocianáttal (52)}

Ahogy az 5.2.3.-as fejezetben leírtuk, a 67-es (157 mg, 0,50 mmol) vagy a 149-es oximot (195 mg, 0,50 mmol) NBS-del (89 mg, 0,50 mmol) reagáltattuk. Ezután az oldószert bepároltuk, a maradékot toluolban oldottuk $(5 \mathrm{ml})$, majd fenilizocianátot $(\mathbf{5 2}, 0,06 \mathrm{ml}, 0,50$ mmol) adtunk hozzá. Oszlopkromatográfiás tisztítást követően nyertük a 153a vagy a 156a vegyületet.

\subsubsection{A 16-brómmetil-nitron (142a vagy 150a) reakciója 4-metoxi-fenilizocianáttal (151)}

Ahogy az 5.2.3.-as fejezetben leírtuk, a 67-es (157 mg, 0,50 mmol) vagy a 149-es oximot (195 mg, 0,50 mmol) NBS-del $(89 \mathrm{mg}, 0,50 \mathrm{mmol})$ reagáltattuk. Ezután az oldószert bepároltuk, a maradékot toluolban (5 ml) oldottuk és 4-metoxi-fenilizocianátot (151, 0,07 ml, 0,50 mmol) adtunk hozzá. Oszlopkromatográfiás tisztítást követően nyertük a 154a vagy a 157 a vegyületet.

\subsubsection{A 16-brómmetil-nitron (142a vagy 150a) reakciója 4-klór-fenilizocianáttal (152)}

Ahogy az 5.2.3.-as fejezetben leírtuk, a 67 -es (157 mg, 0,50 mmol) vagy a 149-es oximot (195 mg, 0,50 mmol) NBS-del $(89 \mathrm{mg}, 0,50 \mathrm{mmol})$ reagáltattuk. Ezután az oldószert

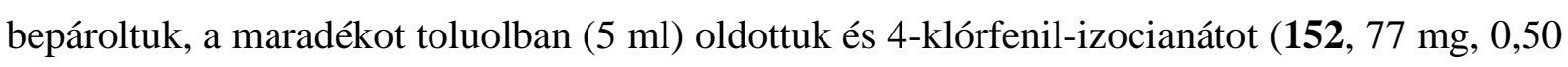
mmol) adtunk hozzá. Oszlopkromatográfiás tisztítást követően nyertük a 155a vagy a 158a vegyületet. 


\subsubsection{A 16-jódmetil-nitron (142b vagy 150b) reakciója fenilizocianáttal (52)}

Ahogy az 5.2.3.-as fejezetben leírtuk, a 67-es (157 mg, 0,50 mmol) vagy a 149-es oximot (195 mg, 0,50 mmol) NIS-del $(113 \mathrm{mg}, 0,50 \mathrm{mmol})$ reagáltattuk. Ezután az oldószert bepároltuk, a maradékot toluolban $(5 \mathrm{ml})$ oldottuk és fenilizocianátot $(\mathbf{5 2}, 0,06 \mathrm{ml}, 0,50$ mmol) adtunk hozzá. Oszlopkromatográfiás tisztítást követően nyertük a 153b vagy a 156b vegyületet.

\subsubsection{A 16-jódmetil-nitron (142b vagy 150b) reakciója 4-metoxi-fenilizocianáttal (151)}

Ahogy az 5.2.3.-as fejezetben leírtuk, a 67-es (157 mg, 0,50 mmol) vagy 149-es oximot (195 $\mathrm{mg}, 0,50 \mathrm{mmol}) \mathrm{NIS}$-del $(113 \mathrm{mg}, 0,50 \mathrm{mmol})$ reagáltattuk. Ezután az oldószert bepároltuk, a maradékot toluolban $(5 \mathrm{ml})$ oldottuk és 4-metoxi-fenilizocianátot $(\mathbf{1 5 1}, 0,07 \mathrm{ml}, 0,50 \mathrm{mmol})$ adtunk hozzá. Oszlopkromatográfiás tisztítást követően nyertük a 154b vagy a 157b vegyületet.

\subsubsection{16-jódmetil-nitron (142b vagy 150b) reakciója 4-klór-fenilizocianáttal (152)}

Ahogy az 5.2.3.-as fejezetben leírtuk, a 67-es (157 mg, 0,50 mmol) vagy a 149-es oximot (195 mg, 0,50 mmol) NIS-del $(113 \mathrm{mg}, 0,50 \mathrm{mmol})$ reagáltattuk. Ezután az oldószert bepároltuk, majd a maradékot toluolban $(5 \mathrm{ml})$ oldottuk és 4-klór-fenilizocianátot $(\mathbf{1 5 2}, 77$ mg, 0,50 mmol) adtunk hozzá. Oszlopkromatográfiás tisztítást követően nyertük a $\mathbf{1 5 5 b}$ vagy a $\mathbf{1 5 8 b}$ vegyületet.

III. Összefoglaló táblázat

A vegyületek fizikai adatai.

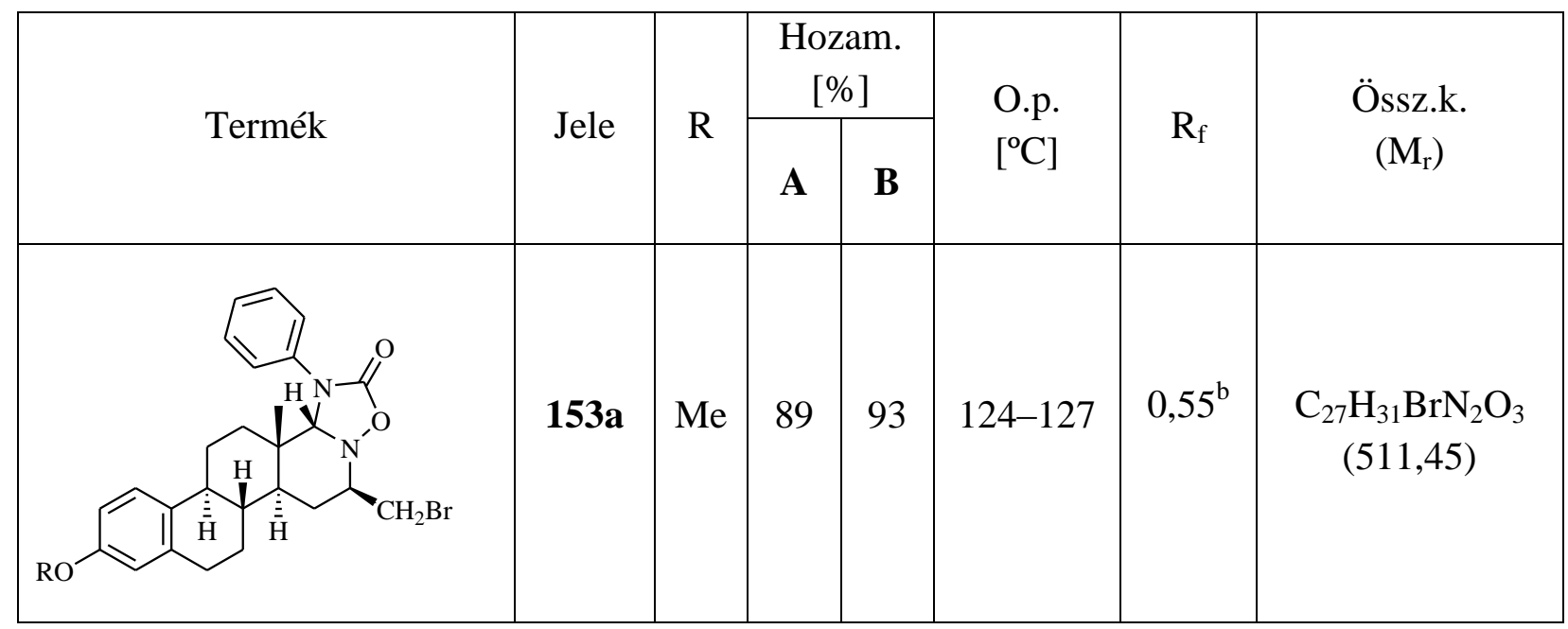




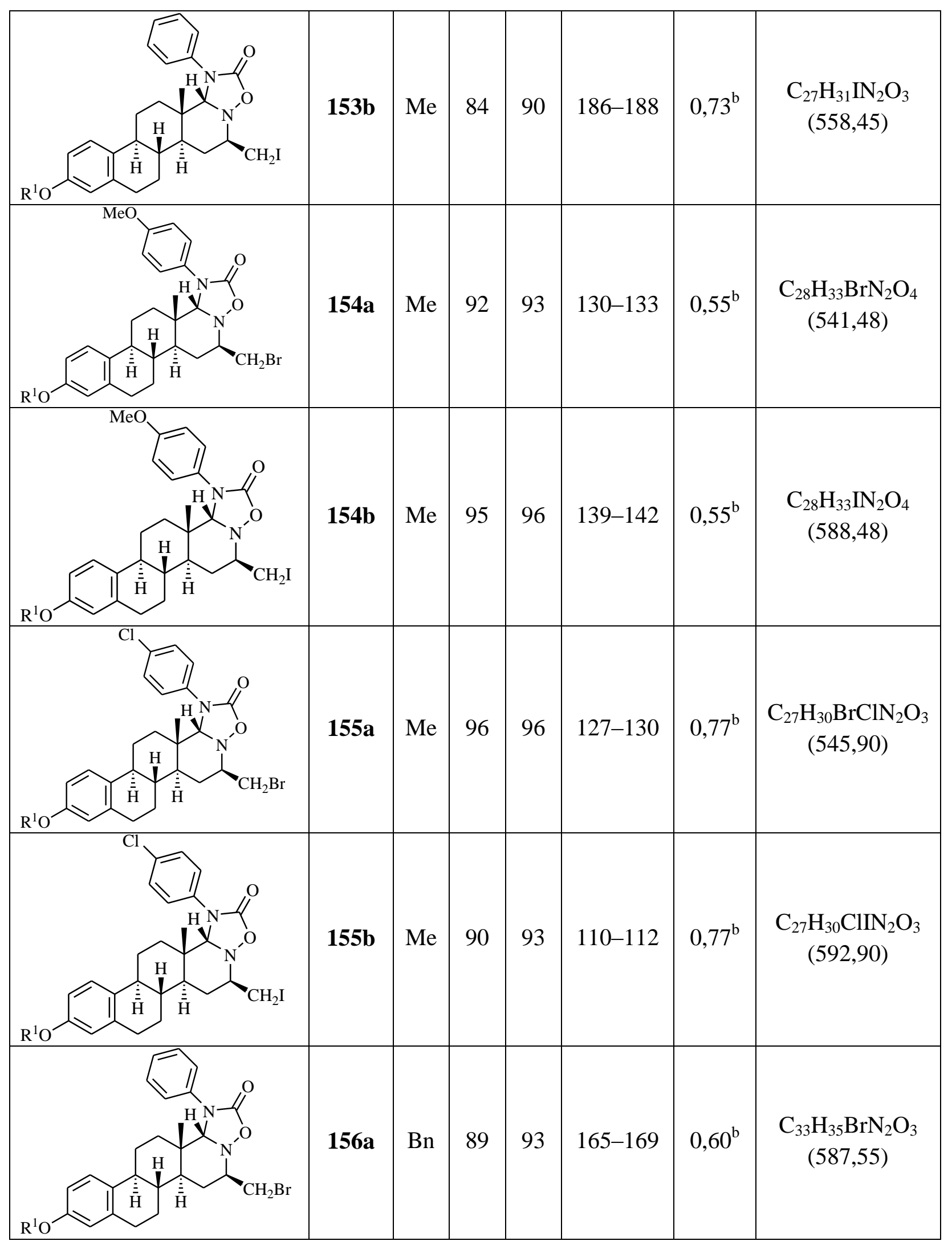




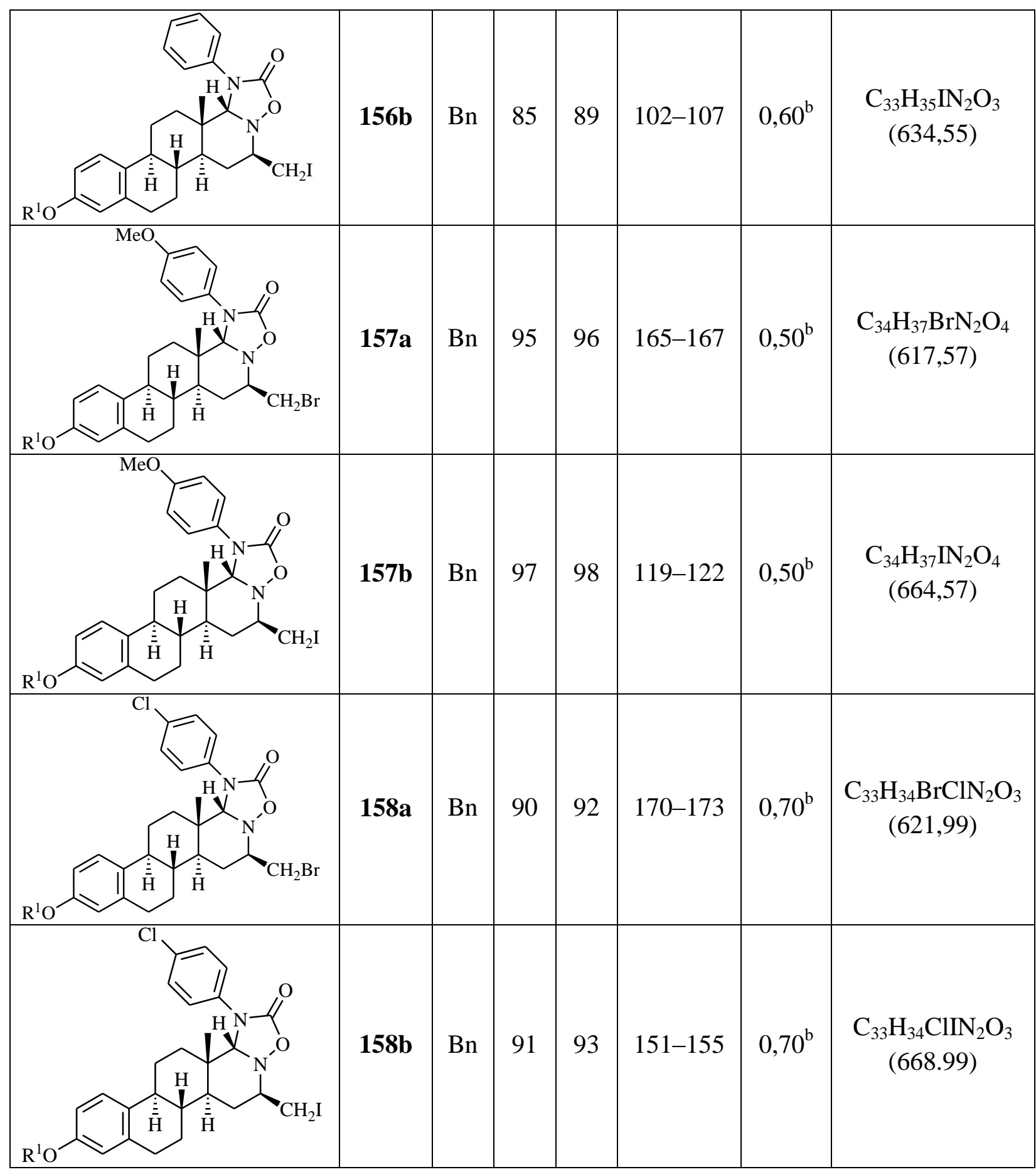




\subsubsection{A $\Delta^{16,17}$-származék elóállítása, azidoalkoholok képzése és azok CuAAC reakciói}

\subsubsection{A brómhidrinek (160a,b és 161a,b) elöállítása}

Az ösztron-3-benzil-étert $(\mathbf{8}, 10 \mathrm{~g}, 27,7 \mathrm{mmol})$ toluol $(180 \mathrm{ml})$ és metanol $(180 \mathrm{ml})$ elegyében oldottuk, majd $\mathrm{CuBr}_{2}$-ot $(14 \mathrm{~g}, 62,7 \mathrm{mmol}$ ) adtunk hozzá. 45 perc forralás után a reakcióelegyet hagytuk szobahőmérsékletüre hülni, ezt követően szürtük, és toluollal mostuk. A szürletet harmadára pároltuk, vízzel elhígítottuk és 1:1 arányú toluol/éterrel extraháltuk. Az összegyüjtött szerves fázisokat vízzel mostuk, és vízmentes $\mathrm{Na}_{2} \mathrm{SO}_{4}$-on szárítottuk. Bepárlás után a nyers termékeket $(11,3 \mathrm{~g}, 93 \%, \mathbf{1 5 9 a}$ és 159b) metanol (150 ml) és diklórmetán $(50 \mathrm{ml})$ elegyében oldottuk, majd jéghütés mellett nátrium-tetrahidrido-borátot $(10 \mathrm{~g}, 148,8 \mathrm{mmol})$ adtunk hozzá kis részletekben. 5 óra elteltével híg sósavoldatra $(15 \mathrm{ml})$ öntöttük, és diklórmetánnal extraháltuk, majd bepároltuk. Az előállított brómhidrin keveréket (160a, b és 161a, b) további tisztítás és szétválasztás nélkül alakítottuk tovább.

\subsubsection{A szteroid-olefin (162) elöállítása}

$800 \mathrm{mg}$ (1,80 mmol) brómhidrin keveréket (160a, b és 161a, b) jégecetben $(150 \mathrm{ml})$ oldottunk, majd cinkport (1270 mg, 19,4 mmol) adtunk hozzá. 5 órás forralás után a reakcióelegyet dupla redős szürőn szürtük, majd jeges vízre öntöttük. Azután diklórmetános extrakciót végeztünk, a szerves fázisokat összegyüjtöttük és vízmentes $\mathrm{Na}_{2} \mathrm{SO}_{4}$-on szárítottuk. Az oldószert bepároltunk. A terméket oszlopkromatográfiásan tisztítottuk, eluensként 2:8 arányú diklórmetán/hexánt alkalmaztunk. A kromatográfia során tisztán nyertük a 162-es jelü vegyületet.

\subsubsection{Az $\alpha$-epoxid (163) elöállítása}

A 3-benziloxiösztra-1,3,5(10),16-tetraént $(\mathbf{1 6 2}, 345 \mathrm{mg}, 1,00 \mathrm{mmol})$ diklórmetánban (7 ml) oldottuk, majd hozzáadtuk a metanolban oldott $(7 \mathrm{ml})$ magnézium-monoperoxiftaláthexahidrátot $(\sim 85 \%, 1,9 \mathrm{~g}, \sim 4,00 \mathrm{mmol})$, és a reakciót szobahőmérsékleten 24 órán át kevertük. Ezután híg nátrium-szulfit oldatot adtunk hozzá, majd diklórmetánnal $(7 \mathrm{ml})$ elhígítottuk. A szerves fázist elkülönítettük, a vizes fázist pedig diklórmetánnal extraháltuk. A szerves fázisokat egyesítettük, vízmentes $\mathrm{Na}_{2} \mathrm{SO}_{4}$-on szárítottuk, az oldószert bepároltuk. A terméket oszlopkromatográfiásan tisztítottuk, eluensként 1:9 arányú EtOAc/hexánt alkalmaztunk. A kromatográfia során tisztán nyertük a 163-as jelü vegyületet. 


\subsubsection{A brómhidrin (164) elöállítása}

Az olefint (162, $345 \mathrm{mg}, 1,00 \mathrm{mmol})$ dimetil-szulfoxidban $(13 \mathrm{ml})$ melegítve oldottuk, ezután felmelegített vizet $(0,5 \mathrm{ml})$ adtunk hozzá, majd hagytuk a reakcióelegyet szobahőmérsékletüre hülni. Ezt követően jeges-vizes fürdő mellett kis részletekben $N$-brómszukcinimidet $(285 \mathrm{mg}$, 1,00 mmol) adagoltunk a reakcióelegyhez. 1 óra elteltével az elegyet vízre öntöttük, és dietiléterrel extraháltuk. A szerves fázisokat összegyüjtöttük, vízmentes $\mathrm{Na}_{2} \mathrm{SO}_{4}$-on szárítottuk, az oldószert bepároltuk. Oszlopkromatográfiás tisztítást végeztünk 3:7 arányú terc-butil-metiléter/hexán eleggyel. A kromatográfiás tisztítás során tisztán nyertük a 164-es jelü vegyületet.

\subsubsection{A $\beta$-epoxid (165) elöállítása}

A brómhidrint (164, $441 \mathrm{mg}, 1,00 \mathrm{mmol})$ metanolban $(7 \mathrm{ml})$ oldottuk, $60{ }^{\circ} \mathrm{C}$-ra melegítettük, majd $12 \mathrm{ml}$ (5\%-os) metanolos kálium-karbonát oldatot adtunk hozzá. 8 óra keverés után a reakcióelegyet vízre öntöttük, és diklórmetánnal extraháltuk. Az egyesített szerves fázisokat vízmentes $\mathrm{Na}_{2} \mathrm{SO}_{4}$-on szárítottuk és az oldószert bepároltuk. Oszlopkromatográfiás elválasztást végeztünk 1:9 arányú EtOAc/hexán eluenseleggyel. A kromatográfiás tisztítás során tisztán nyertük a 165-ös jelü $\beta$-epoxidot.

\subsubsection{Az epoxidnyitás $(163,165)$ általános leírása}

A 163-as vagy a 165-ös jelü epoxidot $(360 \mathrm{mg}, 1,00 \mathrm{mmol})$ dimetil-szulfoxidban (10 ml) oldottuk, és jégecetet $(1 \mathrm{ml})$, valamint $\mathrm{NaN}_{3}$-ot $(455 \mathrm{mg}, 7,00 \mathrm{mmol})$ adtunk hozzá. A reakcióelegyet 3 órán keresztül forraltuk, majd szobahőmérsékletüre hütöttük. Azután az elegyet jeges vízre öntöttük, $\mathrm{NaCl}$ hozzáadása után diklórmetánnal extraháltuk. $\mathrm{Az}$ összegyüjtött szerves fázisokat a semleges $\mathrm{pH}$ eléréséig vízzel mostuk, majd vízmentes $\mathrm{Na}_{2} \mathrm{SO}_{4}$-on szárítottuk és az oldószert bepároltuk. A terméket oszlopkromatográfiásan, 2:8 arányú EtOAc/hexán eluenssel tisztítottuk.

\subsection{A 16ß-azido-3-benziloxiösztra-1,3,5,(10)-trién-17a-ol (166) szintézise}

Az 5.2.4.6. fejezetben leírtak alapján a 163-as jelü epoxidot (360 mg, 1,00 mmol) NaN $\mathrm{N}_{3}$-dal (455 mg, 7,00 mmol) reagáltattuk. A kromatográfiás tisztítás során a 166-os jelü vegyületet nyertük.

\subsection{A 16 $\alpha$-azido-3-benziloxiösztra-1,3,5,(10)-trién-17ß-ol (167) szintézise}

Az 5.2.4.6. fejezetben leírtak alapján a 165-ös jelü epoxidot (360 mg, 1,00 mmol) $\mathrm{NaN}_{3}$-dal (455 mg, 7,00 mmol) reagáltattuk. A kromatográfiás tisztítás során a 167-es jelü vegyületet nyertük. 


\subsubsection{A triazolok $(169,170)$ elóállításának általános leírása}

A 16 $\beta$-azido-3-benziloxiösztra-1,3,5(10)-trién-17 $\alpha$-olt vagy a 16 $\alpha$-azido-3-benziloxiösztra1,3,5(10)-trién-17ß-olt (167 vagy 166; $100 \mathrm{mg}, 0,25 \mathrm{mmol})$ toluolban oldottuk (5 ml), majd trifenilfoszfánt (13 mg, 0,05 mmol), CuI-ot (4,7 mg, 0,025 mmol), diizopropil-etilamint $(0,13$ $\mathrm{ml}, 0,75 \mathrm{mmol})$ és a megfelelő terminális alkint (168, 1,1 ekvivalens) adtuk hozzá. A reakcióelegyet 2 órán át forraltuk, hagytuk szobahőmérsékletüre hülni, azután az oldószert bepároltuk. A termékeket (169a-e és 170a-e) 3:7 arányú EtOAc/hexán eluenssel tisztítottuk.

\subsection{3-benziloxi-16ß-[4-fenil-1H-1,2,3-triazol-1-il]-ösztra-1,3,5(10)-trién-17a-ol (169a)} Az 5.2.4.7. fejezetben leírtak alapján a 166-os jelü azidoalkoholt (100 mg, 0,25 mmol) fenilacetilén $(\mathbf{1 6 8 a}, 0,030 \mathrm{ml})$ reagáltattuk. A kromatográfiás tisztítás során a 169a jelü vegyületet nyertük.

\subsection{3-benziloxi-16ß-[4-(3-tolil)-1H-1,2,3-triazol-1-il]-ösztra-1,3,5(10)-trién-17a-ol (169b)}

Az 5.2.4.7. fejezetben leírtak alapján a 166-os jelü azidoalkoholt (100 mg, 0,25 mmol) 3etiniltoluollal $(\mathbf{1 6 8 b}, 0,036 \mathbf{m l})$ reagáltattuk. A kromatográfiás tisztítás során a $\mathbf{1 6 9 b}$ jelü vegyületet nyertük.

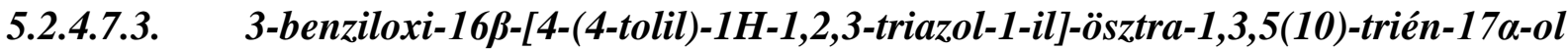
$(169 c)$

Az 5.2.4.7. fejezetben leírtak alapján a 166-os jelü azidoalkoholt (100 mg, 0,25 mmol) 4etiniltoluollal $(\mathbf{1 6 8 c}, 0,035 \mathrm{ml})$ reagáltattuk. A kromatográfiás tisztítás során a $169 \mathrm{c}$ jelü vegyületet nyertük.

\subsection{3-benziloxi-16ß-[4-\{4-(trifluormetil)fenil\}-1H-1,2,3-triazol-1-il]-ösztra-1,3,5(10)-} trién-17a-ol (169d)

Az 5.2.4.7. fejezetben leírtak alapján a 166-os jelü azidoalkoholt (100 mg, 0,25 mmol) 1etinil-4-(trifluormetil)-benzollal $\mathbf{( 1 6 8 d}, 0,039 \mathrm{ml})$ reagáltattuk. A kromatográfiás tisztítás során a 169d jelü vegyületet nyertük. 
5.2.4.7.5. 3-benziloxi-16ß-[4-(4-etilfenil)-1H-1,2,3-triazol-1-il]-ösztra-1,3,5(10)-trién-17a-ol $(169 e)$

Az 5.2.4.7. fejezetben leírtak alapján a 166-os jelü azidoalkoholt (100 mg, 0,25 mmol) 4-etil1-etinil-benzollal $(\mathbf{1 6 8 e}, 0,039 \mathrm{ml})$ reagáltattuk. A kromatográfiás tisztítás során a 169e jelü vegyületet nyertük.

\subsection{3-benziloxi-16 $\alpha$-[4-fenil-1H-1,2,3-triazol-1-il]-ösztra-1,3,5(10)-trién-17ß-ol (170a)} Az 5.2.4.7. fejezetben leírtak alapján a 167-es jelü azidoalkoholt (100 mg, 0,25 mmol) fenilacetilénnel $(\mathbf{1 6 8 a}, 0,030 \mathrm{ml})$ reagáltattuk. A kromatográfiás tisztítás során a $\mathbf{1 7 0 a}$ jelü vegyületet nyertük.

\subsection{3-benziloxi-16 $\alpha$-[4-(3-tolil)-1H-1,2,3-triazol-1-il]-ösztra-1,3,5(10)-trién-17ß-ol (170b)}

Az 5.2.4.7. fejezetben leírtak alapján a 167-es jelü azidoalkoholt (100 mg, 0,25 mmol) 3etiniltoluollal $(\mathbf{1 6 8 b}, 0,036 \mathrm{ml})$ reagáltattuk. A kromatográfiás tisztítás során a $\mathbf{1 7 0 b}$ jelü vegyületet nyertük.

\subsection{3-benziloxi-16 $\alpha$-[4-(4-tolil)-1H-1,2,3-triazol-1-il]-ösztra-1,3,5(10)-trién-17ß-ol (170c)}

Az 5.2.4.7. fejezetben leírtak alapján a 167-es jelü azidoalkoholt (100 mg, 0,25 mmol) 4etiniltoluollal $(\mathbf{1 6 8 c}, 0,035 \mathrm{ml})$ reagáltattuk. A kromatográfiás tisztítás során a $\mathbf{1 7 0 c}$ jelü vegyületet nyertük.

5.2.4.7.9. 3-benziloxi-16a-[4-\{4-(trifluormetil)fenil\}-1H-1,2,3-triazol-1-il]-ösztra-1,3,5(10)trién-17a-ol (170d)

Az 5.2.4.7. fejezetben leírtak alapján a 167-es jelü azidoalkoholt (100 mg, 0,25 mmol) 1etinil-4-(trifluormetil)-benzollal $\mathbf{( 1 6 8 d}, 0,039 \mathrm{ml})$ reagáltattuk. A kromatográfiás tisztítás során a 170d jelü vegyületet nyertük.

5.2.4.7.10. 3-benziloxi-16ß-[4-(4-etilfenil)-1H-1,2,3-triazol-1-il]-ösztra-1,3,5(10)-trién-17aol (170e)

Az 5.2.4.7. fejezetben leírtak alapján a 167-es jelü azidoalkoholt (100 mg, 0,25 mmol) 4-etil1-etinil-benzollal $(\mathbf{1 6 8 e}, 0,039 \mathrm{ml})$ reagáltattuk. A kromatográfiás tisztítás során a 170e jelü vegyületet nyertük. 


\subsubsection{16ß-azido-ösztron-3-benzil-éter (171) szintézise}

A 16 $\beta$-azido-3-benziloxi-ösztra-1,3,5,(10)-trién-17 $\alpha$-olt (166, $403 \mathrm{mg}, 1,00 \mathrm{mmol})$ acetonban (2 ml) oldottunk. Jeges-vizes hütés mellett Jones-reagenst $(0,4 \mathrm{ml})$ adtunk hozzá. Szobahőmérsékleten 1 órán keresztül kevertük, vízre öntöttük, diklórmetánnal extraháltuk. A szerves fázisokat egyesítettük, majd vízmentes $\mathrm{Na}_{2} \mathrm{SO}_{4}$-on szárítottuk és az oldószert bepároltuk. A terméket oszlopkromatográfiásan tisztítottuk, 1:9 arányú EtOAc/hexán eluenssel. A kromatografiás tisztítás során nyertük az azidoketont (171).

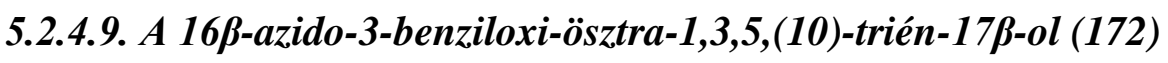

A 16ß-azido-ösztron-3-benzil-étert $(\mathbf{1 7 1}, 401 \mathrm{mg}, 1,00 \mathrm{mmol})$ metanolban $(5 \mathrm{ml})$ oldottuk, majd nátrium-tetrahidrido-borátot $(190 \mathrm{mg}, 5,00 \mathrm{mmol})$ adtunk hozzá. A reakcióelegyet 1 órán keresztül szobahőmérsékleten kevertük, vízre öntöttük, majd diklórmetánnal extraháltuk. A szerves fázisokat összegyüjtöttük, majd vízmentes $\mathrm{Na}_{2} \mathrm{SO}_{4}$-on szárítottuk és az oldószert bepároltuk. A terméket oszlopkromatográfiásan tisztítottuk, 3:7 arányú EtOAc/hexán eluenssel. A kromatográfiás tisztítás során a 172-es jelü vegyületet nyertük.

\subsubsection{A szteroid-olefin (162) katalitikus hidrogénezése}

$345 \mathrm{mg}(1,00 \mathrm{mmol})$ szteroid-olefint (162) etil-acetátban $(30 \mathrm{ml})$ oldottunk, 0,60 g (10\%) $\mathrm{Pd} / \mathrm{C}$ katalizátort adtunk hozzá, majd a reakcióelegyet 20 bar hidrogén nyomás alatt 8 órán át kevertük. A katalizátort szüréssel eltávolítottuk. Az oldat bepárlása után kapott nyersterméket (173) oszlopkromatográfiásan tisztítottuk, 3:7 arányú EtOAc/hexán eluenssel.

\section{IV. Összefoglaló táblázat}

A vegyületek fizikai adatai.

\begin{tabular}{|c|c|c|c|c|c|}
\hline Képlet & Jele & $\begin{array}{c}\text { Hozam } \\
{[\%]}\end{array}$ & $\begin{array}{c}\text { Op. } \\
{\left[{ }^{\circ} \mathrm{C}\right]}\end{array}$ & $\mathrm{R}_{\mathrm{f}}$ & $\begin{array}{c}\text { Össz. k. } \\
\left(\mathrm{M}_{\mathrm{r}}\right)\end{array}$ \\
\hline $\mathbf{1 6 2}$ & 90 & $87-89$ & $0,91^{\mathrm{e}}$ & $\begin{array}{c}\mathrm{C}_{25} \mathrm{H}_{28} \mathrm{O} \\
(344,49)\end{array}$ \\
\hline
\end{tabular}




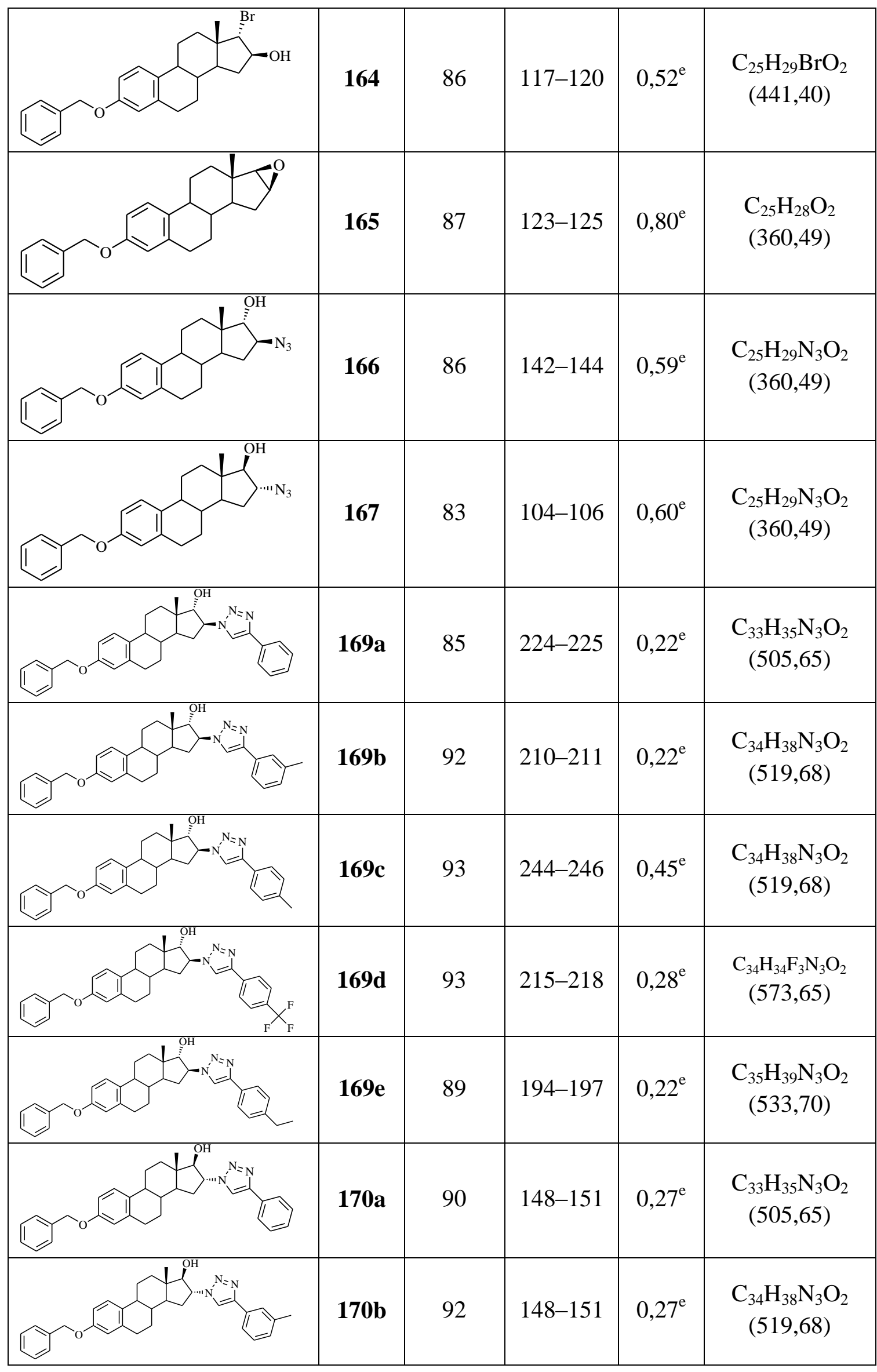




\begin{tabular}{|l|l|l|l|l|}
\hline & 91 & $198-200$ & $0,24^{\mathrm{e}}$ & $\begin{array}{c}\mathrm{C}_{34} \mathrm{H}_{38} \mathrm{~N}_{3} \mathrm{O}_{2} \\
(519,68)\end{array}$ \\
\hline
\end{tabular}

\subsubsection{A 13a-D-szekoaldehid 3-metil- és 3-benzil-éterének (102, 103) Prins-Ritter reakciói}

\section{Általános szintézismódszer}

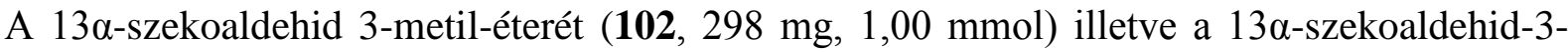
benzil-éterét $(\mathbf{1 0 3}, 375 \mathrm{mg}, 1,00 \mathrm{mmol})$ acetonitrilben $(\mathbf{1 7 4}, 10 \mathrm{ml})$, klóracetonitrilben $(\mathbf{1 7 5}$, $10 \mathrm{ml}$ ) vagy benzonitrilben $(\mathbf{1 7 6}, 10 \mathrm{ml})$ oldottuk, majd $\mathrm{BF}_{3} \cdot \mathrm{OEt}_{2}$-ot (48\%-os oldat, 0,29 ml, 1,00 mmol) adtunk hozzá. A reakcióelegyet 5 percig kevertük. Ezután vízre öntöttük (20 ml), diklórmetánnal extraháltuk. Az összegyüjtött szerves fázist a semleges pH eléréséig vízzel mostuk, $\mathrm{Na}_{2} \mathrm{SO}_{4}$-on szárítottuk, és az oldószert bepároltuk.

\subsubsection{A 102-es és a 103-as jelü vegyület gyürüzárása acetonitril (174) jelenlétében}

Az „Általános szintézismódszernél” ismertetett leírás alapján elvégeztük a 102-es (298 mg, $1,00 \mathrm{mmol}$ ) illetve a $\mathbf{1 0 3}$-as (375 mg, 1,00 mmol) jelü vegyület gyürüzárását, acetonitriles 
közegben $(\mathbf{1 7 4}, 10 \mathrm{ml}), \mathrm{BF}_{3} \cdot \mathrm{OEt}_{2}(48 \%$-os oldat, 0,29 ml, 1,00 mmol) jelenlétében. A 102-ből nyert termékelegy szétválasztását oszlopkromatográfiával, 1:9 arányú MeOH/EtOAc eluenssel végeztük. A tisztítás során előbb a 177a jelü vegyületet, majd a 177b jelü származékot nyertuik. A 103-ból nyert termékelegy szétválasztását szintén oszlopkromatográfiával, 1:9 arányú $\mathrm{MeOH} / \mathrm{EtOAc}$ eluenssel végeztük. A kromatografiás tisztítás során előbb a 180a jelü vegyületet, majd a 180b jelű származékot nyertük.

\subsubsection{A 102-es és a 103-as jelü vegyület gyürüzárása klóracetonitril (175) jelenlétében}

$\mathrm{Az}$ „Általános szintézismódszernél” ismertetett leírás alapján elvégeztük a 102-es (298 mg, 1,00 mmol) illetve a 103-as (375 mg, 1,00 mmol) jelü vegyület gyürüzárását, klóracetonitriles közegben $(\mathbf{1 7 5}, 10 \mathrm{ml}), \mathrm{BF}_{3} \cdot \mathrm{OEt}_{2}(48 \%$-os oldat, 0,29 ml, 1,00 mmol) jelenlétében. A 102-böl nyert termékelegyet oszlopkromatográfiával, 3:7 arányú EtOAc/ $\mathrm{CH}_{2} \mathrm{Cl}_{2}$ eluenssel végeztük. A tisztítás során előbb a 178b jelü vegyületet, majd a 178a jelü, végül a 178c jelü származékot nyertük. A 103-ból nyert termékelegyet szintén oszlopkromatográfiával, 3:7 arányú EtOAc/ $\mathrm{CH}_{2} \mathrm{Cl}_{2}$ eluenssel végeztük. A kromatografiás tisztítás során előbb a $\mathbf{1 8 1 b}$ jelü vegyületet, majd a 181a jelü, végül a 181c jelü származékot nyertük.

\subsubsection{A 102-es és a 103-as jelü vegyület gyürüzárása benzonitril (176) jelenlétében}

Az „Általános szintézismódszernél” ismertetett leírás alapján elvégeztük a 102-es (298mg, $1,00 \mathrm{mmol})$ illetve a $\mathbf{1 0 3}$-as $(375 \mathrm{mg}, 1,00 \mathrm{mmol})$ jelű vegyület gyürűzárását, benzonitriles közegben $(\mathbf{1 7 6}, 10 \mathrm{ml}), \mathrm{BF}_{3} \cdot \mathrm{OEt}_{2}(48 \%$-os oldat, 0,29 ml, 1,00 mmol) jelenlétében. A 102-ből nyert termékelegyet oszlopkromatográfiával, 2:8 arányú EtOAc/ $\mathrm{CH}_{2} \mathrm{Cl}_{2}$ eluenssel végeztük. A tisztítás során előbb a 179b jelü vegyületet, majd a 179a jelü származékot nyertük. A 103-ból nyert termékelegyet szintén oszlopkromatográfiával, 2:8 arányú EtOAc/ $\mathrm{CH}_{2} \mathrm{Cl}_{2}$ eluenssel végeztük. A kromatografiás tisztítás során előbb a 182b jelű vegyületet, majd a 182a jelü származékot nyertük.

\subsubsection{Acetilezés}

A 180b jelü vegyületet $(100 \mathrm{mg}, 0,23 \mathrm{mmol}) 1 \mathrm{ml}$ piridinben oldottuk, és $1 \mathrm{ml}$ ecetsavanhidriddel reagáltattuk. A reakcióelegyet 24 órán át szobahőmérsékleten kevertük, majd híg sósavoldatra öntöttük $(15 \mathrm{ml})$. Diklórmetános extrakciót végeztünk. Az egyesített szerves fázist semleges $\mathrm{pH}$ eléréséig vízzel mostuk, majd izzított $\mathrm{Na}_{2} \mathrm{SO}_{4}$-on szárítottuk. Az oldószert bepároltuk. Az így nyert terméket oszlopkromatográfiásan tisztítottuk. Eluensként EtOAc-ot alkalmaztunk, a kromatográfiás tisztítás során a 184-es jelü származékot nyertük. 
V. Összefoglaló táblázat

A vegyületek fizikai adatai.

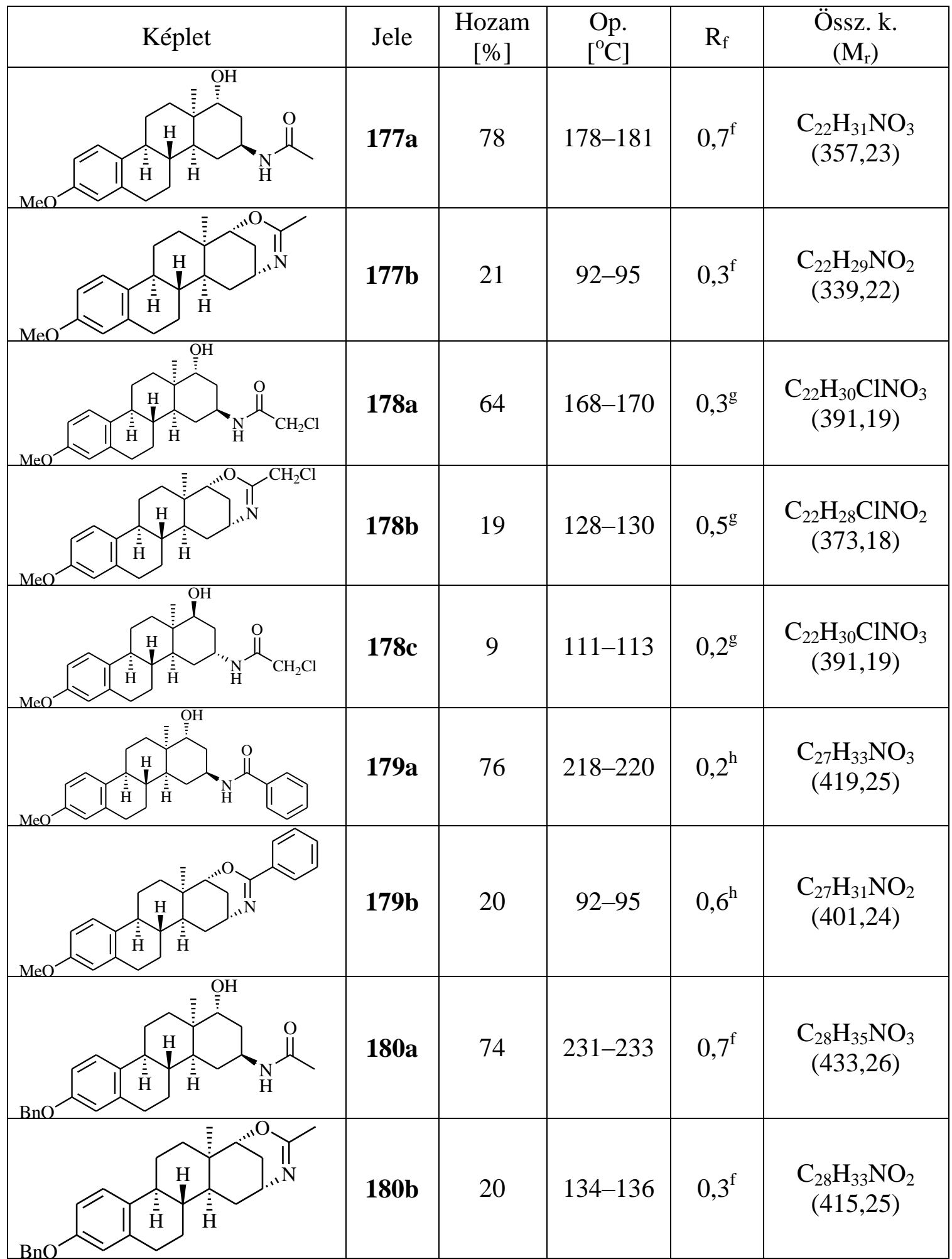




(181a




\section{6. ÖSSZEFOGLALÁS}

Kutatásunk során antitumor hatású ösztronszármazékokat állítottunk elő, amelyeket a 13ß- és a 13a-ösztron vázmódosításával, a D-gyürü homologizálásával és szubsztituálásával, valamint heterociklusok beépítésével valósítottunk meg. A 13a-D-szekoösztron-aldehid-3-metiléteréből (102) oximot (135) állítottunk elő (67. ábra). Az oxim (135) Lewis-sav-indukált intramolekuláris gyürüzárása két, cisz-gyürüanellációval rendelkező izoxazolidin sztereoizomerhez $(\mathbf{1 3 7}, \mathbf{1 3 8})$ vezetett, 1:1 arányban. Melléktermékként dimetil-acetál (136) képződését tapasztaltuk. Amennyiben a gyürüzárásokat $N$-metil-hidroxilamin-hidrokloriddal végeztük, egy sztereoizomer (139) képződését tapasztaltuk. A cisz-gyürüanellációkat NOENMR felvételekkel bizonyítottuk. Kísérleti munkánk folytatásában a $13 \alpha$ - és a $13 \beta$-ösztron sorbeli $\delta$-alkenil-D-szekooximok-3-metil-étereiböl $(67,135)$ elektrofil-indukált (NIS, NBS, $\mathrm{I}_{2}$ ) gyürüzárási reakcióban nitron dipólusokat $(142,143)$ állítottunk elő (67. ábra). A gyürüs nitron dipólusokat $(\mathbf{1 4 2}, \mathbf{1 4 3}) \mathrm{C}=\mathrm{C}$ dipolarofillel $(\mathbf{1 4 4}, N$-fenilmaleimid, NFM), 1,3-dipoláris cikloaddíciós reakcióval alakítottuk át. A szintézisek sztereoszelektíven szolgáltatták a 16brómmetil- (145a, 146a), illetve a 16-jódmetil-izomereket (145b, 146b). Az újonnan szintetizált D-homoösztronok $(\mathbf{1 4 5}, \mathbf{1 4 6})$ szerkezetét 1D- illetve 2D-NMR-spektroszkópiás felvételekkel bizonyítottuk. A 145-ös és a 146-os cikloadduktumokat összehasonlítva megfigyelhető, hogy a $13 \alpha$-ösztron származékok (145a, b) szubsztituensei a 13ß-ösztron származékokhoz (146a, b) képest ellentétes térállásúak; a 16-halometilcsoport $\alpha$-, a 3'-H és a 4'-H $\beta$-térállású. A 13ß-sorbeli oxim (67) brómozási reakciójánál egy nem szimmetrikus szteroid dimer (148) képződését tapasztaltuk. Ennek magyarázata, hogy az oxim (67) viselkedhet ambidens nukleofilként, így az $O$-alkilezéssel képződött oxazepin származék (147) mint $\mathrm{C}=\mathrm{N}$ dipolarofil reakcióba lép az $N$-alkilezéssel kapott gyürüs nitron (142) 1,3dipólussal, így alakul ki a dimer (148). A dimerképződés reverzibilis, ugyanis acetonitriles oldatához NFM-et (144) adva a korábbi cikloadduktumhoz (146a) jutunk. Diklórmetános közegben is kialakul a dimer (148), de jó oldékonysága miatt nem válik ki az oldatból. Az 1,3-dipoláris cikloaddíciós szintézisek sorát a $13 \beta$-sorbeli $\delta$-alkenil-D-szekooximok-3-metililletve 3-benzil-éterének $(\mathbf{6 7}, \mathbf{1 4 9}) \mathrm{C}=\mathrm{N}$ dipolarofilekkel történő gyürüzárásaival folytattuk, amelyek kemoszelektíven, kiváló hozammal szolgáltatták az ösztránváz D-gyürüjéhez kondenzált oxadiazolidinon származékokat (153-158, 67. ábra). A reakciók régiószelektívnek bizonyultak, minden esetben a dipolarofil $N$-atomja kapcsolódott a szteránváz 17aszénatomjához. A reakciósebességben eltérések mutatkoztak. Az elektronküldő $(-\mathrm{I}<+\mathrm{M})$ 
csoporttal rendelkező 4-metoxi-fenilizocianát (151) alkalmazása során tapasztaltuk a legrövidebb reakcióidőt, ezt a 4-klór származékkal $(\mathbf{1 5 2}$, -I > +M) végrehajtott 1,3-dipoláris cikloaddíciók követték, majd a leghosszabb reakcióidőt a szubsztituálatlan fenilizocianát (52) esetében figyeltuik meg. A hagyományos melegítés mellett kipróbáltuk a mikrohullámú technikát is, amellyel 1 perc alatt, sztereo-, régió- és kemoszelektíven nyertük a kívánt oxadiazolidinon származékokat (153-158). A fenilizocianát $(\mathbf{5 2}, \mathbf{1 5 1}, \mathbf{1 5 2})$ szubsztituenseinek minősége nem befolyásolta a mikrohullámmal végrehajtott reakciók sebességét. A biológiai vizsgálatok alapján (MTT-analízis és az áramlási citometria) azt a következtetést vontuk le, hogy az ösztránvázon a 3-as helyzetü benzil védőcsoport jelenléte, a D-gyürü homologizálása, a heterociklusos gyürü molekulára történő kiépítése, illetve a 16-os helyzetben lévő $\mathrm{CH}_{2} \mathrm{I}$ szubsztituens növeli a tumorszelektív sejtosztódást-gátló hatást.

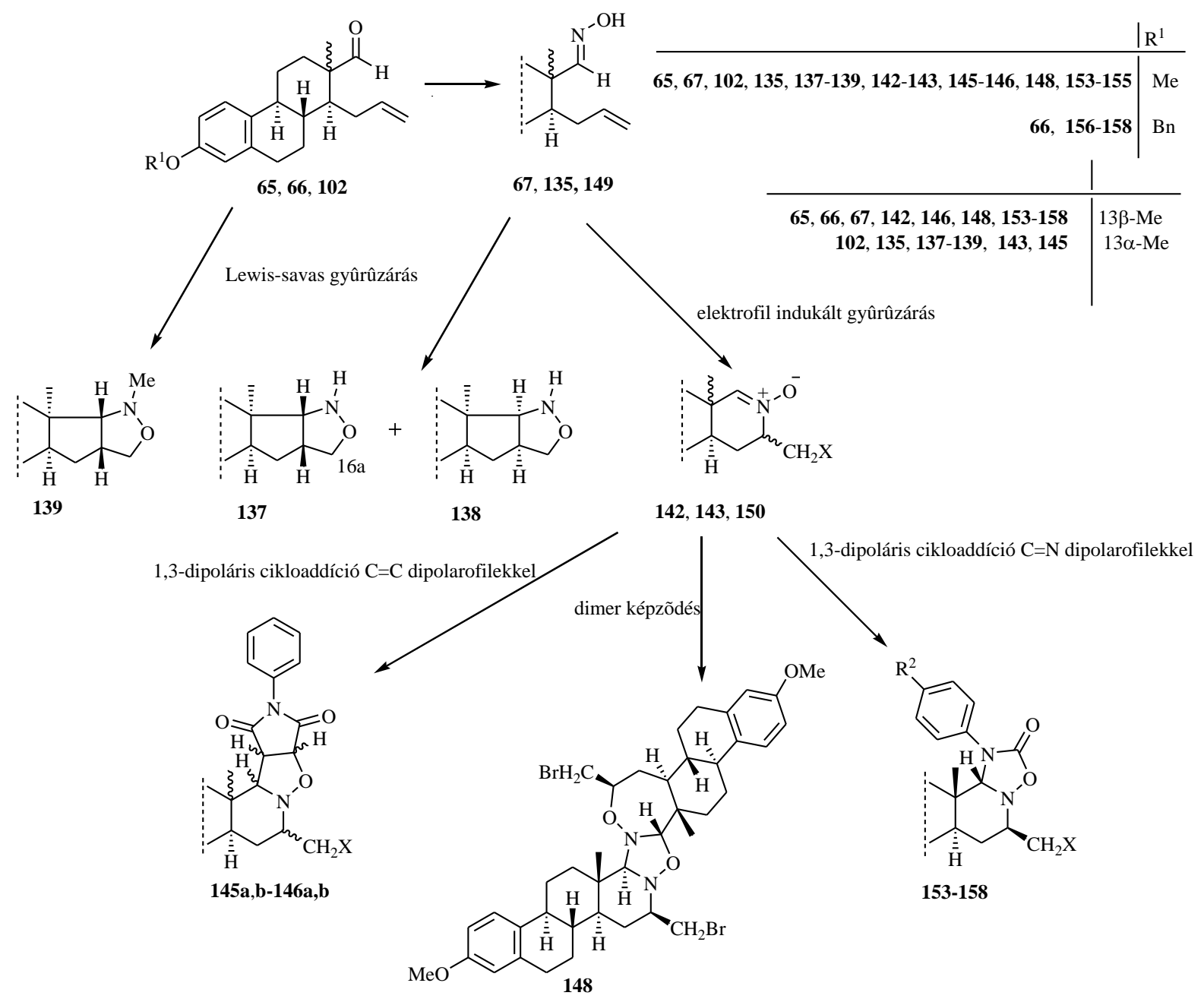

67. ábra: Lewis-sav és elektrofil-indukált nitronképzés, és az azt követő 1,3-dipoláris cikloaddíció 
A nitron dipólusok előállítását, és 1,3-dipoláris cikloaddíciós reakcióját követően megvalósítottuk a szteroid azidok (166, 167) CuAAC szintéziseit monoszubsztituált acetilénekkel (168a-e, 68. ábra), amelyek régiószelektíven szolgáltatták a 16-triazol származékokat (169a-e, 170a-e). Abból a célból, hogy a későbbi biológiai vizsgálatokhoz további származékokat nyerjünk, a 16 $\beta$-azido-17 $\alpha$-hidroxiösztron-3-benzil-étert (166) különböző átalakításoknak vetettük alá. Így oxidáltuk a 17-es hidroxilcsoportot (171), majd visszaredukáltuk (172), így olyan vegyületekhez jutottunk, amelyek a hatástani vizsgálatok során hasznos szerkezet-hatás összefüggéseket nyújthatnak. Célunk volt az is, hogy meghatározzuk, hogy a biológiai aktivitáshoz szükséges-e a 17-es oxigén-funkció jelenléte, így kerülő úton megvalósítottuk annak eltávolítását is, 17-dezoxi származék (173) előállítása céljából. A hatástani vizsgálatok eredményeiből feltételezzük, hogy a 17-es szénatomon lévő hidroxil-funkció jelenléte szükséges az antitumor hatás kialakulásához, annak oxidációja (171) aktivitás-csökkenéshez vezetett. A kettős kötést tartalmazó 16-olefin (162) illetve a triazol-funkció molekulára történő kiépítése kedvezőtlenül befolyásolja a sejtosztódást-gátló hatást.

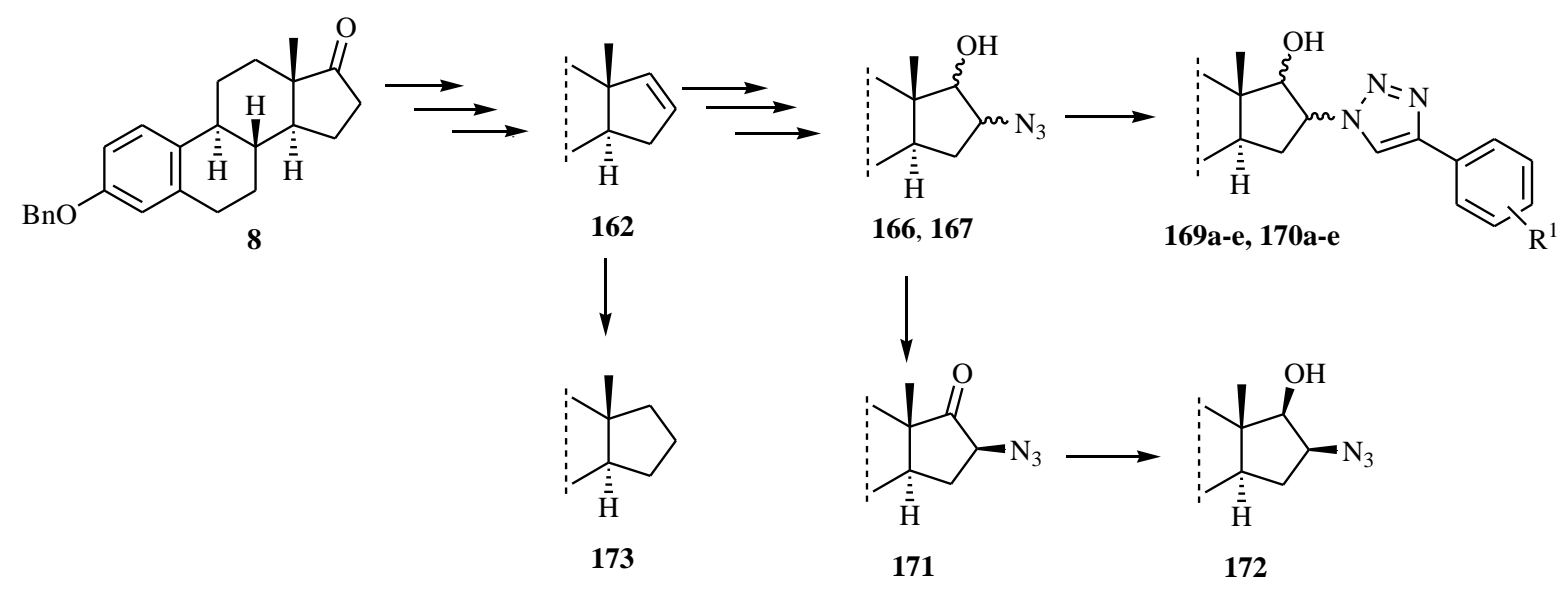

68. ábra: A szteroid-azidok $(\mathbf{1 6 6}, \mathbf{1 6 7})$ előállítása, és 1,3-dipoláris cikloaddíciós reakciói

Kutatómunkánk következő részében folytattuk az új, nitrogéntartalmú D-homoösztron származékok előállítását. A 13 $\alpha$-ösztron sorbeli D-szekoaldehid 3-metil- és 3-benzil-éterét (102, 103) Lewis-sav-indukált Prins-reakcióval D-homológokká alakítottuk, majd a 16-os szénatomon kialakuló karbokationra nukleofil beépítését valósítottuk meg a Ritter-reakció 
körülményei között, „one pot” eljárással (69. ábra). Lewis-sav katalizátorként $\mathrm{BF}_{3} \cdot \mathrm{OEt}_{2}$-ot, oldószerként és nukleofil reagensként pedig különbözö nitrileket (acetonitril (174), klóracetonitril (175), benzonitril (176)) használtunk. Azt tapasztaltuk, hogy a Prins-Ritter reakciók eredményeként két új kiralitáscentrum alakult ki (C-16, C-17a), így négy sztereoizomer képződését vártuk. A szintézisek során azonban két-két termék keletkezett (4:1 arányban), a klóracetonitriles reakcióknál pedig három (7:2:1 arányban): a várt 16- $N$-acil-17hidroxi származékok (177a, c - 182a, c) mellett új, áthidalt típusú vegyületek (177b-182b) jelentek meg. NMR-felvételek segítségével megállapítottuk, hogy a főtermékek (177a-182a) minden esetben 16ß,17a $\alpha$-transz-vegyületek, a melléktermékek (177b-182b) áthidalt-típusú 16 $\alpha, 17$ a $\alpha$-dihidrooxazin származékok, míg a klóracetonitriles reakcióknál megjelenő harmadik vegyületek (178c, 181c) a fötermékek (177a-182a) diasztereomer párjai $(16 \alpha, 17 \mathrm{a} \beta$ transz-vegyületek). Megállapítottuk, hogy a Prins-Ritter termékek (177-182) szerkezeti különbségei nagyban befolyásolják azok sejtosztódást gátló aktivitását. A főtermékek (177a, 180a) kevésbé hatásosak az áthidalt típusú vegyületekhez $(177 b, 180 b)$ képest. A 180b jelü D-homoszteroid az összes sejtvonalon a ciszplatinnal összemérhető értéket ad $\left(\mathrm{IC}_{50} \sim 1 \mu \mathrm{M}\right)$, de nem szelektál az egyes sejtvonalak között. Azt tapasztaltuk, hogy a 3-as helyzetü benzilvédőcsoport jelenléte növeli a vegyületek sejtosztódást gátló aktivitását. Az $N$-klóracetil származékok $(\mathbf{1 7 8}, 181)$ szélesebb hatásspektrummal rendelkeznek, a 3-benzil-éter sorban (181a-c) 90\% körüli gátlást mutatnak minden sejtvonalon. Az $N$-benzoil származékok (179, 182) a legkevésbé hatásosak. A 180b jelü gyürüs melléktermék tumorszelektív, továbbá nem mutatott jelentősebb hatásbeli különbségeket az eltérő receptorokat tartalmazó emlőkarcinóma sejtvonalakon, így feltételezzük, hogy a származék (180b) hormonreceptorfüggetlen módon fejti ki antitumor aktivitását. Az áramlási citometriás analízisből azt a következtetést vontuk le, hogy rövid expozíciós idő alatt (24 óra) a sejtciklus G1-S átmenetét, míg hosszabb expozíciós idő alatt (48 óra) a G2/M fázis blokádját okozza. Továbbá a tesztanyag (180b) a tubulin polimerizáció sebességét növelte, hasonlóan, mint a referenciavegyületként használt paklitaxel, így olyan anomális mikrotubulus-hálózat kialakulását idézi elő, amely nem teszi lehetővé a sejtosztódást. 
<smiles>[R6]c1ccc2c(c1)CC[C@@H]1[C@H](CC=C)[C@H](C=O)CC[C@@H]21</smiles>

102,103

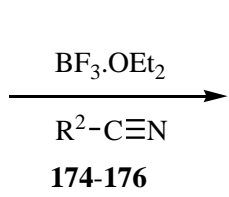

174-176

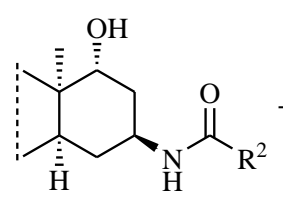

177a-182a

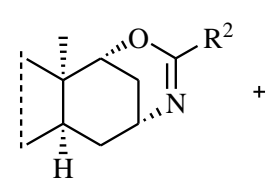

177b-182b<smiles>[R]C(=O)N[C@H]1C[C@@H](O)[C@H](C)[C@H](I)C1</smiles>

$178 \mathrm{c}$

$181 c$

102, 177-179: $\mathrm{R}^{1}=\mathrm{Me} \quad 174,177,180: \mathrm{R}^{2}=\mathrm{Me}$

103, 180-182: $\mathrm{R}^{1}=\mathrm{Bn} \quad$ 175, 178, 181: $\mathrm{R}^{2}=\mathrm{CH}_{2} \mathrm{Cl}$

176, 179, 182: $\mathrm{R}^{2}=\mathrm{Ph}$

69. ábra: A „one pot” Prins-Ritter reakció 


\section{SUMMARY}

The aim of the present study was the synthesis of new oestrone derivatives by homologization and/or substitution of ring $\mathrm{D}$, or by introduction of a heterocyclic moiety into the $13 \beta$ - and $13 \alpha$-oestrone scaffolds. In the first part of our work, steroidal nitrone and azide dipoles were synthesized and subjected to 1,3-dipolar cycloadditions. Nitrone dipoles were obtained from the appropriate oestrone seco-oximes by Lewis acid or electrophile-induced cyclizations. The $\delta$-alkenyl-D-seco-aldehyde (102) of $13 \alpha$-oestrone was transformed into the appropriate oxime (135, Scheme 70), and intramolecular cyclization of 135 with $\mathrm{BF}_{3} \cdot \mathrm{OEt}_{2}$ led to two cisisoxazolidine stereoisomers $(\mathbf{1 3 7}, \mathbf{1 3 8})$ in a ratio of $1: 1$. Cyclization of $\mathbf{1 0 2}$ with $\mathrm{N}$ methylhydroxylamine hydrochloride resulted stereoselectively in one product (139). Determination of the stereochemistry of $\mathbf{1 3 7}$ and $\mathbf{1 3 8}$ was based on NOE data. The oximes $(\mathbf{6 7}, \mathbf{1 3 5})$ in the $13 \alpha$ and $13 \beta$ series were transformed into the appropriate nitrones $(\mathbf{1 4 2}, \mathbf{1 4 3})$ by electrophile-induced reactions with various halogenating agents: $N$-bromosuccinimide (NBS), $N$-iodosuccinimide (NIS) or iodine ( $\mathrm{I}_{2}$, Scheme 70$)$. The cycloadditions of the nitrone dipoles $(142,143)$ with a $\mathrm{C}=\mathrm{C}$ dipolarophile $(144, N$-phenylmaleimide, NPM) stereoselectively furnished the 16-bromomethyl- (145a, 146a) and 16-iodomethyl-aza-Dhomo isomers $(\mathbf{1 4 5 b}, \mathbf{1 4 6 b})$. In the $13 \beta$-oestrone series, bromination of 67 led to the formation of a dimeric product (148). We assume that 67 behaved as an ambidentate nucleophile. Trapping of the intermediate bromonium ion proceeded via the $O$-atom in the case of the $Z$-oxime, and via the $N$-atom in the case of the $E$-oxime. The oxazepine derivative (147, as a steroidal $\mathrm{C}=\mathrm{N}$ dipolarophile) and the cyclic nitrone (142, a 1,3-dipole) reacted with each other in an intermolecular 1,3-dipolar cycloaddition stereoselectively, furnishing a nonsymmetrical steroid dimer (148). Subsequent reaction of the cyclic nitrones $(142,150)$ with phenyl isocyanates $(\mathbf{5 2}, \mathbf{1 5 1}, \mathbf{1 5 2})$ as reactive $\mathrm{C}=\mathrm{N}$ dipolarophiles chemoselectively yielded condensed homosteroidal oxadiazolidinones (153-158, Scheme 70). The newly formed stereogenic centres displayed the same configurations as earlier: a $16 \beta$-substituent and a $17 \mathrm{a} \beta$ hydrogen at the anellation of the piperidine and oxadiazolidinone rings. The condensed homosteroidal oxadiazolidinone derivatives (153-158) were formed in high yields, the reaction times depended on the nature of the substituents on the phenyl isocyanate $(\mathbf{5 2}, \mathbf{1 5 1}$, 152). An electron-donating methoxy group on the phenyl ring (151) promoted the reaction, and the dual nature of the chloro substituent (152) also surprisingly accelerated the reaction. The lowest extent of reaction was observed with the unsubstituted reagent (52). The 
antiproliferative properties of the newly synthesized compounds (153-158) were characterized in vitro. Some compounds exerted a high antiproliferative potential. In conclusion, the presence of the benzylic protecting group and the six-membered ring $\mathrm{D}$, the introduction of a heterocyclic moiety into the molecule and the $\mathrm{CH}_{2} \mathrm{I}$ substituent at position C16 proved advantageous for the antiproliferative potential.

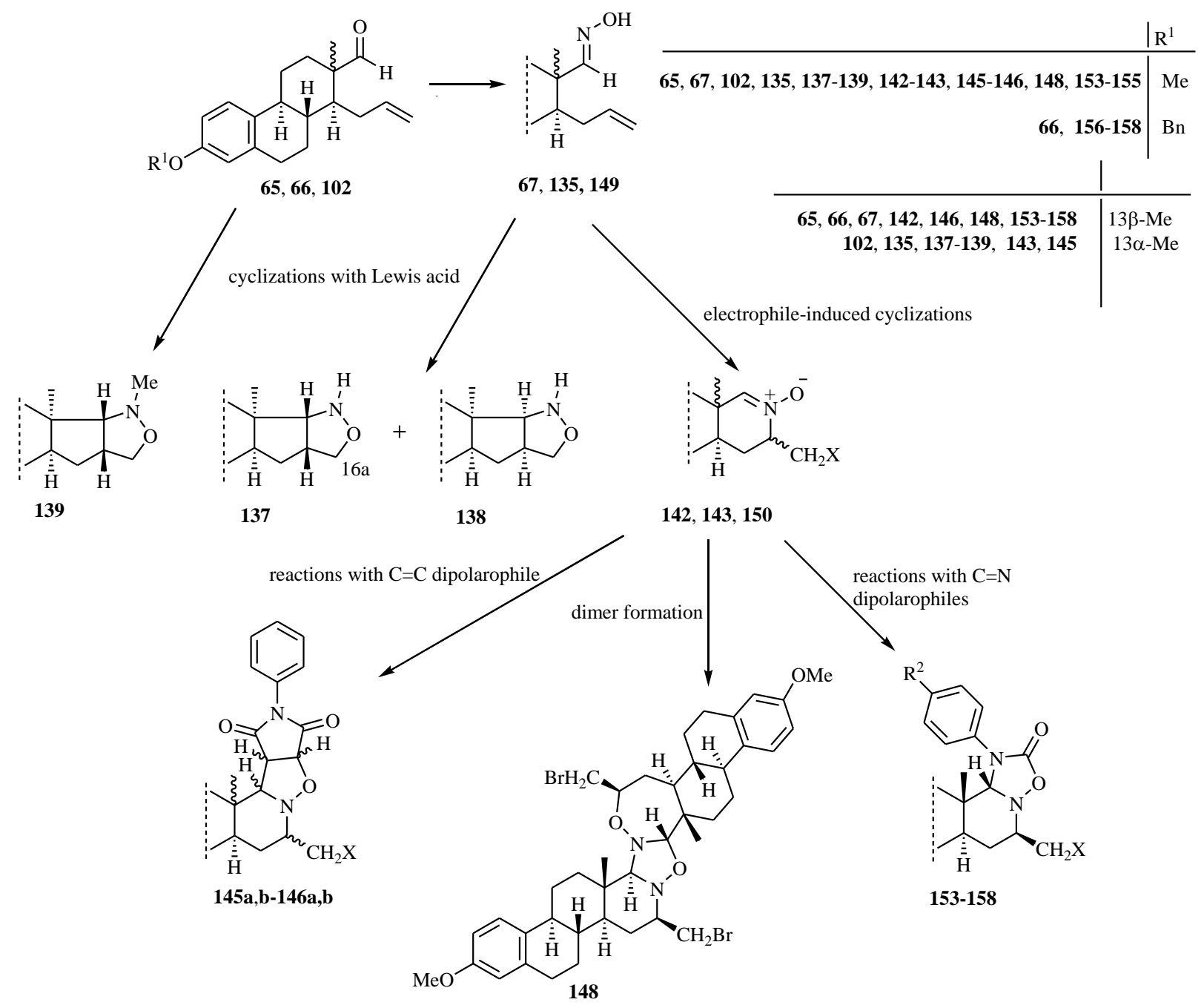

Scheme 70: Lewis acid or electrophile-induced nitrone formation and 1,3-dipolar cycloadditions

After the 1,3-dipolar cycloadditions of the steroidal nitrones, azide dipolarophiles were synthesized in the oestrone series. The ring-opening reactions of the epoxides furnished the azidoalcohols $(\mathbf{1 6 6}, \mathbf{1 6 7})$, which were reacted with substituted phenylacetylenes $(\mathbf{1 6 8 a}-\mathbf{e})$ in CuAAC reactions (Scheme 71). The cyclizations proceeded regioselectively, leading to the appropriate 16-triazolyl derivatives (169a-e and 170a-e) in high yields. In order to obtain 
further derivatives for the structure-activity relationship, the 17-OH group was modified with the aim of determining the dependence of the nature of the 17-substituent on the antiproliferative properties. Jones oxidation of the $16 \beta$-azido-17 $\alpha$-hydroxy derivative (166) led to the 16ß-azidooestrone 3-benzyl ether (171). Reduction of 171 furnished the cisazidoalcohol (172). The benzylic protecting group of the 16-olefin (162) was removed by catalytic hydrogenation, during which saturation of the double bond also occurred, leading to the 17-desoxy derivative (173). The antiproliferative properties of the newly synthesized compounds $(\mathbf{1 6 2}-173)$ were tested in vitro. The azidoalcohols $(166,167,172)$ proved to be more potent than the triazoles $(169 a-\mathbf{a}$ and $170 a-\mathbf{e})$, while the presence of the 17-keto function was disadvantageous. The 17-desoxy derivative (173) displayed an outstanding antiproliferative potential.

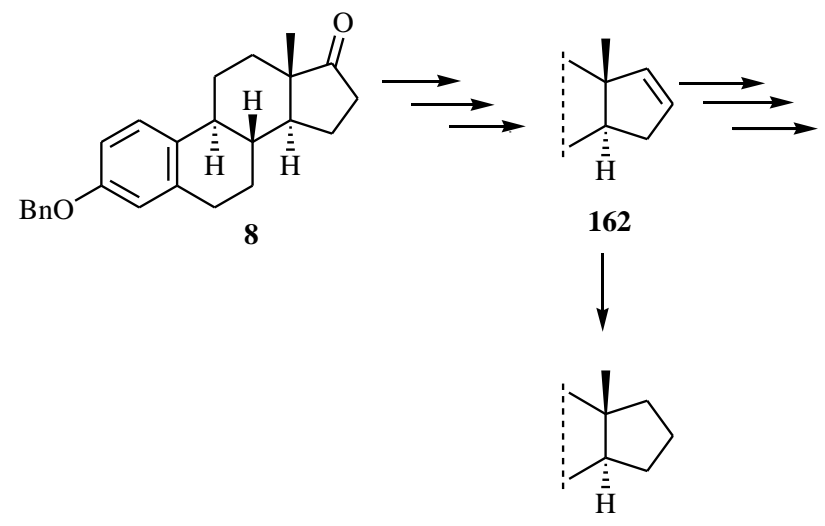

173
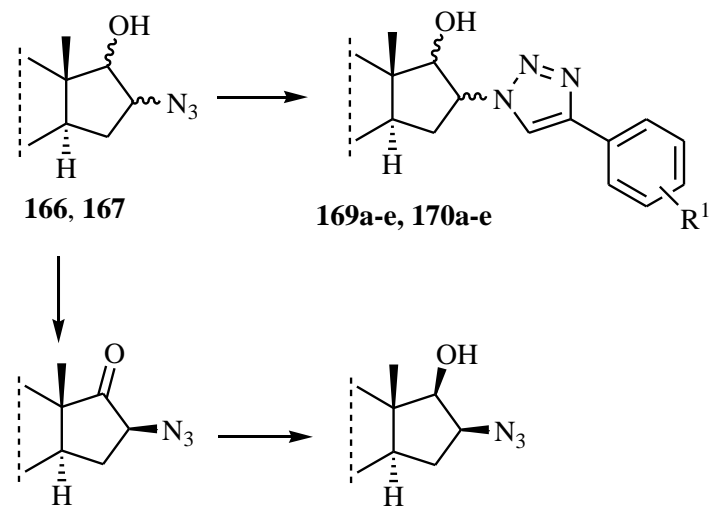

171

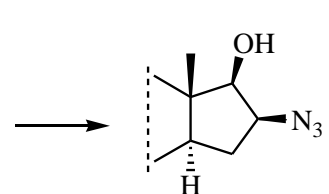

172

Scheme 71: Synthesis of steroid azides $(\mathbf{1 6 6}, \mathbf{1 6 7})$ and their $\mathrm{CuAAC}$ reactions with substituted phenylacetylenes (168a-e)

The „one pot” Prins-Ritter reactions of the $\delta$-alkenyl-D-seco-oestrone 3-benzyl or 3methyl ether $(\mathbf{1 0 2}, \mathbf{1 0 3})$ in the $13 \alpha$-oestrone series were carried out with $\mathrm{BF}_{3} \cdot \mathrm{OEt}_{2}$ as catalyst and different nitriles (aceto- (174), chloroaceto- (175) and benzonitrile (176)) as reagents and solvents (Scheme 72). The first reaction step was the Lewis acid-induced Prins cyclization of the $\delta$-alkenyl aldehyde $(\mathbf{1 0 2}, \mathbf{1 0 3})$, leading to the carbocation at position $\mathrm{C}-16$. This was followed by the Ritter reaction step, with nitriles (174-176) acting as nucleophilic reagents. All the reactions proceeded in a similar manner, yielding two products in a ratio of $4: 1$, a substituted 16- $N$-acyl-17a-hydroxy (177a, $\mathbf{c}-\mathbf{1 8 2 a}, \mathbf{c})$ and a cyclized $(\mathbf{1 7 7 b}-\mathbf{1 8 2} \mathbf{b})$ derivative. With chloroacetonitrile (175) as reagent and solvent, three products were formed 
in a ratio of 7:2:1 in both the 3-benzyl and the 3-methyl ether series. 178c and 181c are diastereomers of the main products $177 \mathbf{a}-\mathbf{1 8 2}$ a. The tumour cell proliferation inhibition caused by the homosteroids $(\mathbf{1 7 7}-\mathbf{1 8 2})$ was greatly affected by the structures of the compounds (177-182). 177a and 180a proved less potent than the bridged products $(\mathbf{1 7 7} \mathbf{b}$, 180b) in both the 3-benzyl and the 3-methyl ether series. 180b displayed outstanding antiproliferative properties against all the tested cell lines, with $\mathrm{IC}_{50}$ values of $\sim 1 \mu \mathrm{M}$. A benzylic protecting group at position C-3 generally improved the growth-inhibitory potential. $\mathrm{N}$-Chloroacetyl derivatives $(\mathbf{1 7 8}, \mathbf{1 8 1})$ displayed a broader spectrum of activities, since all three products $(\mathbf{1 8 1 a}-\mathbf{c})$ in the 3-benzyl ether series exhibited $>90 \%$ inhibition on all cells exept MCF-7 (at $30 \mu \mathrm{M}$ ). The $N$-benzoyl compounds $(\mathbf{1 7 9}, \mathbf{1 8 2}$ ) were less potent derivatives. The most effective Prins-Ritter derivative (180b) was subjected to additional investigations in order to describe its antiproliferative properties against a panel of human breast cancer cell lines differing in receptorial status. Since no substantial differences were detected in the activities of $180 \mathrm{~b}$, its estrogenic effect can be excluded. The direct effect of $\mathbf{1 8 0 b}$ on tubulin polymerization was tested in vitro. The results indicate that $\mathbf{1 8 0 b}$ caused a concentrationdependent increase in the rate of polymerization, similar to that of the reference agent paclitaxel.

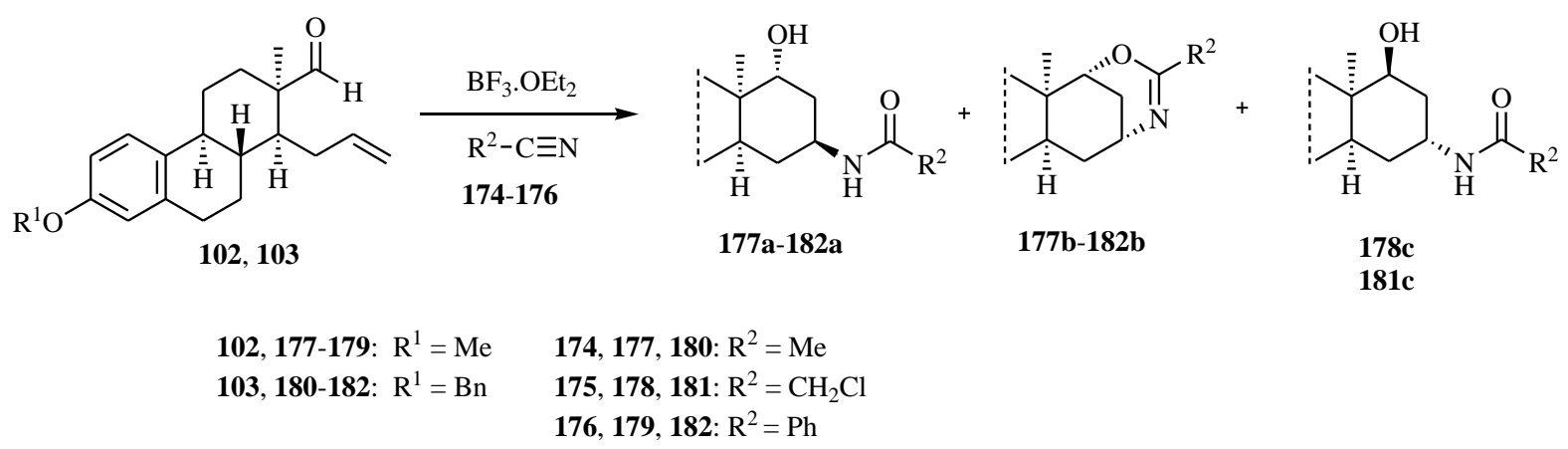

Scheme 72: The „one pot” Prins-Ritter reaction 


\section{IRODALOMJEGYZÉK}

1. Bruckner, Gy. Szerves Kémia II-2, Tankönyvkiadó, Budapest, 1981, 165.

2. Dickson, R. B.; Stancel, G. M. J. Natl. Canc. Inst. Monogr. 2000, 27, 135.

3. Gupta, A.; Kumar, S.B.; Negi, S. A. J. Steroid Biochem. Mol. Biol. 2013, 137, 242.

4. $\quad$ Miller, W. L.; Auchus, R. J. Endocr. Rev. 2011, 32, 81.

5. Hobrik, R. Trends Endocr. Metab. 1993, 4, 69.

6. Numazawa, M.; Ando, M.; Watari, Y.; Tominaga, T.; Hayata, Y.; Yoshimura, A. J. Steroid Biochem. Mol. Biol. 2005, 96, 51.

7. Lawrence, H.; Vicker, H.; Allan, N.; Smith, G. M.; Mahon, A.; Tutill, M.; Purohit, H. J.; Reed, A.; Reed, M. J.; Potter, B. V. L. J. Med. Chem. 2005, 48, 2759.

8. Woo, L. W.; Howarth, N. M.; Purohit, A.; Hejaz, H. A.; Reed, M. J.; Potter, B. V. J. Med. Chem. 1998, 41, 1068.

9. MacCarthy, M. L.; Townsend, P. A.; Purohit, A. Canc. Res. 2001, 60, 5441.

10. Wang, M.; Xu, L.; Gao, M.; Miller, K. D.; Sledge, G. W.; Zheng, Q. H. Steroids 2012, $77,864$.

11. Fischer, D. S.; Chander, S. K.; Woo, L. W. L.; Fenton, J. C.; Purohit, A.; Reed, M. J.; Potter, B. V. L. J. Steroid Biochem. Mol. Biol. 2003, 84, 343.

12. Ray, S.; Dwivedy, I. Adv. Drug Res. 1997, 29, 171.

13. Claussner, A.; Nedelec, L.; Nique, F.; Philbert, D.; Teutsch, G.; Van de Velde, P. J. Steroid Biochem. Mol. Biol. 1992, 41, 609.

14. www.sotepedia.hu/_media/aok/targyak/a_21.doc

15. Cushman, M.; He, H-M.; Katzenellenbogen, J. A.; Lin, C. M.; Hamel, E. J. Med. Chem. 1995, 38, 2041.

16. Hillisch, A.; Peters, O.; Gege, C.; Siemeister, G.; Unger, E.; Menzenbach, B. US Patent: US RE42, 132 E.

17. Wang, Z.; Yang, D.; Mohanakrishnan, A. K.; Fanwick, P. E.; Nampoothiri, P.; Hamel, E.; Lin, C. M.; Cushman, M. J. Med. Chem. 2000, 43, 2419.

18. Tahir, S. K.; Han, E. K. H.; Credo, B.; Jae, H. S.; Pietenpol, J. A.; Scatena, C. D.; WuWong, J. R.; Frost, D.; Sham, H.; Rosenberg, S. H. Canc. Res. 2001, 61, 5480.

19. Hu, Y.; Lu, X.; Chen, K.; Yan, R.; Li, Q. S.; Zhu H. L. Bioorg. Med. Chem. 2012, 20, 903. 
20. Genin, M. J.; Allwin, D. A.; Anderson, D. J.; Barbachyn, M. R.; Emmert, D. E.; Garmon, S. A.; Graber, D. R.; Grega, K. C.; Hester, J. B.; Hutchinson, D. K.; Morris, J.; Reischer, R. D.; Stper, D.; Yagi, B. H. J. Med. Chem. 2000, 43, 953.

21. Aher, N. G.; Pore, V. S.; Mishra, N. N.; Kumar, A.; Shukla, P. K.; Sharma, A.; Bhat, M. K. Bioorg. Med. Chem. Lett. 2009, 19, 759.

22. Buckle, D. R.; Rockell, C. J. M.; Smith, H.; Spicer, B. A. J. Med. Chem. 1986, 29, 2262 .

23. Alvarez, R.; Velazquez, S.; San-Felix, A.; Aquaro, S.; De Clercq, E.; Perno, C-F.; Karlasson, A.; Balzarini, J.; Camarasa, M. J. J. Med. Chem. 1994, 37, 4185.

24. Bock, V. D.; Hiemstra, H.; van Maarseveen, J. H. Eur. J. Org. Chem. 2006, 51.

25. Banday, A. H.; Shameem, S. A.; Gupta, B. D.; Kumar, H. M. S. Steroids 2010, 75, 801.

26. Vatmurge, N. S.; Hazra, B. G.; Pore, V. S.; Shirazi, F.; Chavan, P. S.; Desphande, M. V. Bioorg. Med. Chem. Lett. 2008, 18, 2043.

27. Kovács, D.; Kádár, Z.; Mótyán, G.; Schneider, Gy.; Wölfling, J.; Zupkó, I.; Frank, É. Steroids 2012, 77, 1075.

28. Frank, É.; Molnár, J.; Zupkó, I.; Kádár, Z.; Wölfling, J. Steroids 2011, 76, 1141.

29. Kádár, Z.; Frank, É.; Schneider, Gy.; Molnár, J.; Zupkó, I.; Kóti, J.; Schönecker, B.; Wölfling, J. Arkivoc 2012, (iii), 279.

30. Kádár, Z.; Kovács, D.; Frank, É.; Schneider, Gy.; Huber, J.; Zupkó, I.; Bartók, T.; Wölfling, J. Molecules 2011, 16, 4786.

31. Kádár, Z.; Molnár, J.; Schneider, Gy.; Zupkó, I.; Frank, É. Bioorg. Med. Chem. 2012, 20, 1396.

32. Kádár, Z.; Baji, Á.; Zupkó, I.; Bartók, T.; Wölfling, J.; Frank, É. Org. Biomol. Chem. 2011, 9,8051 .

33. Kádár Z. Doktori Értekezés, Szegedi Tudományegyetem, 2012.

34. Ayan, D.; Jenny, R.; Maltis, R.; Poirier, D. J. Steroid Biochem. Mol. Biol. 2011, 127, 324.

35. Wölfling, J.; Mernyák, E.; Frank, E.; Falkay, Gy.; Márki, Á.; Minorics, R.; Schneider, Gy. Steroids 2003, 68, 277.

36. Minorics, R.; Bózsity, N.; Wölfling, J.; Mernyák, E.; Schneider, Gy.; Márki, Á.; Falkay, Gy.; Ocsovszki, I.; Zupkó, I. J. Steroid. Biochem. Mol. Biol. 2012, 132, 168.

37. Mosmann, T. J. Immunol. Methods 1983, 65, 55. 
38. Bózsity, N. Pályamunka, Szegedi Tudományegyetem, 2013.

39. Berényi, Á.; Minorics, R.; Iványi, Z.; Ocsovszki, I.; Ducza, E.; Thole, H.; Messinger, J.; Wölfling, J.; Mótyán, G.; Mernyák, E.; Frank, É.; Schneider, Gy.; Zupkó, I. Steroids 2013, 78, 69.

40. Berényi, Á. Doktori Értekezés, Szegedi Tudományegyetem, 2013.

41. Padwa, A.; Person, W. H.; Eds. Synthetic Application of 1,3-Dipolar Cycloaddition Chemistry toward Heterocycles and Natural Products, Wiley: Hoboken, New Yersey, 2003.

42. Huisgen, R. Proc. Chem. Soc. 1961, 357.

43. Xu, L.; Doubleday, C. E.; Houk, K. N. J. Am. Chem. Soc. 2010, 132, 3029.

44. Ess, D. H.; Houk, K. N. J. Am. Chem. Soc. 2008, 130, 10187.

45. Xu, L.; Doubleday, C. E.; Houk, K. N. Angew. Chem. Int. Ed. 2009, 48, 2746.

46. Braida, B.; Walter, C.; Engels, B.; Hiberty, P. C. J. Am. Chem. Soc. 2010, 132, 7631.

47. Gothelf, K. V.; Jørgensen, K. A. Chem. Rev. 1998, 98, 863.

48. Dondas, H. A.; Grigg, R.; Hadjisoteriu, M.; Markésu, J.; Thomas, W. A.; Kennewell, P. Tetrahedron 2000, 56, 10087.

49. Fredericson, M.; Grigg, R. Org. Prep. Proced. Int. 1997, 29, 63.

50. Dondas, H. A.; Grigg, R.; Markandu, J.; Perrior, T.; Suzuki, T.; Thibault, S.; Thomas, W. A.; Thornton-Pett, M. Tetrahedron 2002, 58, 161.

51. Dondas, H. A.; Grigg, R.; Hadjisoteriu, M.; Markandu, J.; Thornton-Pett, M. Tetrahedron 2001, 57, 1119.

52. Tiecco, M.; Testaferri, L.; Bagnoli, L.; Marini, F.; Santi, C.; Temperini, A.; Scarponi, C.; Sternativo, S.; Terlizzi, R.; Tomassini, C. Arkivoc 2006, vii, 186.

53. Coșkun, N.; Parlar, A. Synth. Commun. 2006, 36, 997.

54. Buchlovič, M.; Hebanová, S.; Potáček, M. Tetrahedron 2012, 68, 3117.

55. Frank, É.; Wölfling, J.; Aukszi, B.; König, V.; Schneider, R. T.; Schneider, Gy. Tetrahedron 2002, 58, 6843.

56. Mernyák, E.; Benedek, G.; Schneider, Gy.; Wölfling, J. Synlett 2005, 637.

57. Schneider, Gy.; Hackler, L.; Sohár, P. Liebigs Ann. Chem. 1988, 679.

58. Grob, C. A.; Schiess, P. W. Angew. Chem. 1967, 79, 1.

59. Adam, G.; Schreiber, K. Liebigs Ann. Chem. 1967, 709, 191.

60. Michael, A. J. Prakt. Chem. 1893, 48, 94.

61. Huisgen, R. Angew. Chem. Int. Ed. 1963, 2, 565. 
62. Kolb, H. C.; Finn, M. G.; Sharpless, K. B. Angew. Chem. Int. Ed. 2001, 40, 2004

63. Rostovtsev, V. V.; Green, L. G.; Fokin, V. V.; Sharpless, K. B. Angew. Chem. Int. Ed. 2002, 41, 2596.

64. Tornøe, C. W.; Christiensen, C.; Meldal, M. J. Org. Chem. 2002, 67, 3057.

65. Dondoni, A.; Marra, A. J. Org. Chem. 2006, 71, 7546.

66. Liang, C.H.; Yao, S.; Chiu, Y. H.; Leung, P. Y.; Robert, N.; Seddon, J.; Sears, P.; Hwang, C. K.; Ichikawa, Y.; Romero, A. Bioorg. Med. Chem. Lett. 2005, 15, 1307.

67. Malkoch, M.; Thibault, R. J.; Drockenmuller, E.; Messerschimdt, M.; Voit, B.; Russell, T. P.; Hawker, C. J. J. Am. Chem. Soc. 2005, 127, 14942.

68. Golas, P. L.; Tsarevsky, N. V.; Sumerlin, B. S.; Matyjaszewski, K. Macromolecules 2006, 39, 6451.

69. Zhan, W-H.; Barnhill, H. N.; Sivakumar, K.; Tian, H.; Wang, Q. Tetrahedron Lett. 2005, 46, 1691.

70. Speers, A. E.; Cravaat, B. F. Chem. Biol. 2004, 11, 535.

71. Molteni G.; Bianchi C. L.; Marinoni G.; Santo N.; Ponti A. New J. Chem. 2006, 30, 1137.

72. Pacho L. D.; Van Maarseveen J. H; Rothenberg G. Adv. Synth. Catal. 2005, 347, 811.

73. Bacsa, I. Diplomamunka, Szegedi Tudományegyetem, 2014.

74. Himo, F.; Lovell, T.; Hilgraf, R.; Rostovtsev, V. V.; Noodleman, L.; Sharpless, K. B.; Fokin, V.V. J. Am. Chem. Soc. 2005, 1, 210.

75. Meldal, M.; Tornøe, C. W. Chem. Rev. 2008, 108, 2952.

76. Liyuan L.; Didier A. Coord. Chem. Rev. 2011, 255, 2933.

77. Schönecker B.; Ponsold, K.; Neuland, P. Z. Chem. 1970, 10, 221.

78. Schönecker B.; Ponsold, K. Tetrahedron 1975, 31, 1113.

79. Schönecker, B.; Lange, C.; Kötteritzsch, M.; Günther, W.; Weston, J.; Anders, E.; Görls, H. J. Org. Chem. 2000, 65, 5487.

80. Lipshutz, B. H.; Taft, B. R. Angew. Chem. Int. Ed. 2006, 45, 8235.

81. Alonso, F.; Moglie, Y.; Radivoy, G.; Yus, M. Tetrahedron Lett. 2009, 50, 2358.

82. Mernyák, E.; Kovács, I.; Minorics, R.; Sere, P.; Czégány, D.; Sinka, I.; Wölfling, J.; Schneider, Gy.; Újfaludi, Zs.; Boros, I.; Ocsovszki, I.; Varga, M.; Zupkó, I. J. Steroid Biochem. Mol. Biol. 2015, 150, 123.

83. Schneider, Gy.; Mernyák, E.; Wölfling, J.; Holczbauer, T.; Czugler, M.; Sohár, P.; Minorics R.; Zupkó, I. Steroids 2015, 98, 153. 
84. http://www.organic-chemistry.org/namedreactions/prins-reaction.shtm

85. Andersen, N. H.; Hadley, S. W.; Kelly, J. D.; Bacon, E. R. J. Org. Chem. 1985, 50, 4144.

86. Peron, G. L. N.; Kitteringham, J.; Kilburn, J. D. Tetrahedron Lett. 1999, 40, 3045.

87. Molander, G. A.; Cameron, K. O. J. Am. Chem. Soc. 1993, 115, 830.

88. Yaremenko, F: G.; Khvat, A. V. Mendeleev Commun. 1994, 4, 187.

89. Butenandt, A.; Wolff, A.; Karlson, P. Ber. Dtsch. Chem. Ges. 1941, 74, 1308.

90. Mernyák, E.; Wölfling, J.; Bunkóczi, G.; Luo, L.; Schneider, T. R.; Schneider, Gy. Collect. Czech. Chem. Commun. 2003, 68, 1141.

91. Appel, R.; Halstenberg, M. Organophosphorus Reagents in Organic Synthesis Academic Press, New York, 1979, 387.

92. Wölfling, J.; Frank, É.; Mernyák, E.; Bunkóczi, G.; Cvesta Seijo, J. A.; Schneider, Gy. Tetrahedron 2002, 58, 6851.

93. Ritter, J. J., Minieri, P. P. J. Am. Chem. Soc. 1948, 70, 4045.

94. Firouzabadi, H.; Sardarian, R. A.; Badparva, H. Synth. Commun. 1994, 24, 601.

95. Reddy, S. B. V.; Ghanty, S. Synth. Commun. 2014, 44, 2545.

96. Reddy, S. B. V.; Ghanty, S.; Kishore, C.; Sridhar, B. Tetrahedron Lett. 2014, 55, 4298.

97. Sarmah, B.; Baishya, G.; Baruah, R. K. First example of a Prins-Ritter reaction on terpenoids: a diastereoselective route to novel 4-amido-octahydro-2H-chromenes, RSC. Adv. 2014, 4, 22387.

98. Yadav, J. S.; Jayasudhan, R. Y.; Adi, N. R. P.; Suba, R. B. V. Org. Lett. 2013, 15, 546.

99. Yadav, J. S.; Suba, R. D. V.; Aravind, S.; Narayana Kumar G. G. K. S.; Madhavi, C.; Kunwar, A. C. Tetrahedron 2008, 64, 3025.

100. Yadav, J. S.; Suba, R. B. V.; Chaya, D. N.; Narayana Kumar, G. G. K. S. Canad. J. Chem. 2008, 86, 769 .

101. Selvam, N. P.; Perumal, T. P. Canad. J. Chem. 2009, 87, 698.

102. Yadav, J. S.; Suba, R. B. V.; Chaya, D. N.; Narayana Kumar, G. G. K. S. Reddy, G. M. Tetrahedron Lett. 2007, 48, 4903.

103. Mernyák, E.; Huber, J.; Benedek, G.; Pfoh, R.; Rühl, S.; Schneider, Gy.; Wölfling, J. Arkivoc 2010, xi, 101.

104. Mernyák E.; Huber, J.; Szabó, J.; Schneider, Gy.; Hetényi, A.; Márk, L.; Maász, G.; Berényi, Á.; Kovács, I.; Minorics, R.; Zupkó, I.; Wölfling, J. Steroids 2013, 78, 1021. 
105. http://www.chem.umn.edu/groups/taton/chem8361/Handouts/9_26.pdf

106. Sohár P. A mágneses magrezonancia a kémiai szerkezetkutatásban, Magyar Tudomány, Budapest 2014, 3, 278.

107. Mernyák, E.; Kozma, E.; Hetényi, A.; Márk, L.; Schneider, Gy.; Wölfling, J. Steroids 2009, 74, 520 .

108. Montskó, G.; Váczy, A.; Maász, G.; Mernyák, E.; Frank, É.; Bay, Cs. Anal. Bioanal. Chem. 2009, 395, 869.

109. Mernyák, E.; Márk, L.; Frank, É.; Schneider, Gy.; Wölfling, J. Steroids 2009, 74, 474.

110. Huber J.; Wölfling, J.; Schneider, Gy.; Ocsovszki, I.; Varga, M.; Zupkó, I.; Mernyák, E. Steroids 2015, 102, 76 .

111. Agafontsev, A. M.; Rybalova, T. V.; Gatilov, Y. V.; Tkachev, A. V. Mendeleev Commun. 2002, 12, 88 .

112. Agafontsev, A. M.; Tkachev, A. V. Russ. Chem. Bull. Int. Ed. 2005, 54, 1892.

113. Hajnal, A.; Wölfling, J.; Schneider, Gy. Synlett 2002, 7, 1077.

114. Hajnal, A. Doktori Értekezés, Szegedi Tudományegyetem, 2002.

115. Möller, G.; Deluca, D.; Gege, C.; Rosinus, A.; Kowalik, D.; Peters, O.; Droescher, P.; Elger, W.; Adamski, J.; Hillisch, A. Bioorg. Med. Chem. Lett. 2009, 19, 6740.

116. Leese, M. P.; Hejaz, H. A. M.; Mahon, M. F.; Newman, S. P.; Purohit, A.; Reed, M. J.; Potter, B. V. L. J. Med. Chem. 2005, 48, 5243.

117. Mernyák, E.; Szabó, J.; Huber, J.; Schneider, Gy.; Minorics, R.; Bózsity , N.; Zupkó, I.; Varga, M.; Bikádi, Zs.; Hazai E.; Wölfling, J. Steroids 2014, 87, 128.

118. Vermes, I.; Haanen, C.; Reutelingsperger, C. J. Immunol. Methods 2000, 243, 167. 


\section{KÖSZÖNETNYILVÁNÍTÁS}

Mindenekelött köszönettel tartozom témavezetömnek, Dr. Mernyák Erzsébet tudományos munkatársnak, aki kezdetben irányt mutatott tudományos érdeklődésemnek, majd doktori éveim során (időt és fáradtságot nem kímélve) egyengette pályafutásom, és bevezetett a kutatómunka rejtelmeibe. Továbbá köszönöm Neki disszertációm alapos áttanulmányozását, és értékes elméleti és gyakorlati útmutatását.

Köszönettel tartozom továbbá másik témavezetőmnek, Prof. Dr. Wölfling János tanszékvezető egyetemi tanárnak, kutatásaim feltételeinek biztosításáért, személyes konzultációink és publikációs anyagaimhoz nyújtott hasznos tanácsaiért.

Hálával tartozom Dr. Schneider Gyula professzor emeritusnak az évek során adott bölcs észrevételeiért. Köszönettel tartozom Neki, hogy hallgató korom óta folyamatosan figyelemmel kísérte és segítette munkám.

Továbbá köszönöm Dr. Zupkó István egyetemi docensnek antitumor vizsgálataimban nyújtott segítségét és szakmai támogatását.

$\mathrm{Az}$ áramlásos citometriai mérésekért külön köszönet illeti Ocsovszki Imrét (SZTEÁOK Biokémiai Intézet), a tömegspektrometriai analízisért Dr. Varga Mónikát (Szegedi Gabonakutató Nonprofit Kft.) és az NMR vizsgálatokban nyújtott segítségéért Dr. Hetényi Anasztáziát (SZTE-ÁOK, Orvosi Vegytani Intézet).

Hálával tartozom a Szteroidkémiai Kutatócsoport és a Gyógyszerhatástani és Biofarmáciai Intézet minden tagjának, különösképpen Szabó Johannának, Bacsa Ildikónak, Farkas Nórának, Gabnai Jánosnak, Dr. Minorics Renátának, Dr. Berényi Ágnesnek és nem utolsó sorban Dr. Kovács Ida Jusztinának, akikhez bármikor fordulhattam munkám során felmerülő problémáimmal. Mindemellett megköszönöm a disszertáció témájához kapcsolódó közlemények, poszterek és előadások valamennyi társszerzőjének a segítségét.

Külön köszönettel tartozom családomnak és jegyesemnek Mag Pálnak, akik mindvégig mellettem álltak, türelmesek voltak, és biztosították a munkámhoz szükséges nyugodt hátteret. 


\section{MELLÉKLET}

I. melléklet

A vegyületek NMR-és MS-adatai.

135

${ }^{1} \mathrm{H}-\mathrm{NMR}\left(500 \mathrm{MHz}, \mathrm{CDCl}_{3}\right): \delta$ [ppm] = 1,20 (s, 3H, 18- $\left.\mathrm{H}_{3}\right) ; 2,83\left(\mathrm{~m}, 2 \mathrm{H}, 6-\mathrm{H}_{2}\right) ; 3,77$ (s, 3H, 3-OMe); 5,01 (m, 2H, 16a-H2); 5,83 (m, 1H, 16-H); 6,61 (d, 1H, J = 2,5 Hz, 4-H); 6,70 (dd, $1 \mathrm{H}, J=8,6 \mathrm{~Hz}, J=2,5 \mathrm{~Hz}, 2-\mathrm{H}) ; 7,18(\mathrm{~d}, 1 \mathrm{H}, J=8,6 \mathrm{~Hz}, 1-\mathrm{H}) ; 7,57$ (s, 1H, 17-H). ${ }^{13} \mathrm{C}-\mathrm{NMR}$ $\delta[\mathrm{ppm}]=26,3(\mathrm{C}-18) ; 27,0 ; 27,4 ; 30,3 ; 33,3 ; 39,1 ; 40,9 ; 42,3 ; 43,5 ; 50,8 ; 55,2$ (3-OMe); 111,7 (C-2); 113,4 (C-4); 114,9 (C-16a); 126,4 (C-1); 132,2 (C-10); 137,8 (C-5); 139,4 (C16); 155,9 (C-17); 157,5 (C-3). MS (70 eV); m/z (\%): $313\left(100, \mathrm{M}^{+}\right) ; 296(53) ; 173$ (47); 147 (49); 70 (61); 41 (42).

\section{6}

${ }^{1} \mathrm{H}-\mathrm{NMR}\left(500 \mathrm{MHz}, \mathrm{CDCl}_{3}\right): \delta[\mathrm{ppm}]=0,99\left(\mathrm{~s}, 3 \mathrm{H}, 18-\mathrm{H}_{3}\right) ; 2,84\left(\mathrm{~m}, 2 \mathrm{H}, 6-\mathrm{H}_{2}\right) ; 3,43$ és 3,48 (2xs, 2x3H, 2x acetil-OMe); 3,76 (s, 3H, 3-OMe); 4,33 (s, 1H, 17-H); 5,00 (m, 2H, 16a- $\mathrm{H}_{2}$ ); $5,86(\mathrm{~m}, 1 \mathrm{H}, 16-\mathrm{H}) ; 6,61(\mathrm{~d}, 1 \mathrm{H}, J=2,5 \mathrm{~Hz}, 4-\mathrm{H}) ; 6,70(\mathrm{dd}, 1 \mathrm{H}, J=8,6 \mathrm{~Hz}, J=2,5 \mathrm{~Hz}, 2-\mathrm{H})$; $7,19(\mathrm{~d}, 1 \mathrm{H}, J=8,6 \mathrm{~Hz}, 1-\mathrm{H}) .{ }^{13} \mathrm{C}-\mathrm{NMR} \delta$ [ppm] $=23,4$ (C-18); 27,0; 28,1; 30,5; 32,6; 36,6; 42,1; 42,2 (C-13); 44,1; 52,0; 55,1 (3-OMe); 57,8 és 58,4 (2C, 2xacetil-OMe); 110,7 (C-17); 111,5 (C-2); 113,4 (C-4); 113,5 (C-16a); 126,3 (C-1); 133,1 (C-10); 137,9 (C-5); 141,8 (C16); 157,5 (C-3). MS (70 eV); $m / z(\%) 344\left(23, \mathrm{M}^{+}\right), 239$ (11), 75 (100).

\section{7}

${ }^{1} \mathrm{H}-\mathrm{NMR}\left(500 \mathrm{MHz}, \mathrm{CDCl}_{3}\right): \delta[\mathrm{ppm}]=1,01\left(\mathrm{~s}, 3 \mathrm{H}, 18-\mathrm{H}_{3}\right) ; 2,83\left(\mathrm{~m}, 2 \mathrm{H}, 6-\mathrm{H}_{2}\right) ; 3,13(\mathrm{~m}, 1 \mathrm{H}$, $16-\mathrm{H}) ; 3,45(\mathrm{~d}, 1 \mathrm{H}, J=7,6 \mathrm{~Hz}, 17-\mathrm{H})$; 3,64 és 3,78 (2xm, 2x1H, 16a-H $)$; 3,79 (s, 3H, 3$\mathrm{OMe}) ; 6,62(\mathrm{~d}, 1 \mathrm{H}, J=2,0 \mathrm{~Hz}, 4-\mathrm{H}) ; 6,72(\mathrm{dd}, 1 \mathrm{H}, J=8,6 \mathrm{~Hz}, J=2,0 \mathrm{~Hz}, 2-\mathrm{H}) ; 7,24(\mathrm{~d}, 1 \mathrm{H}, J$ $=8,6 \mathrm{~Hz}, 1-\mathrm{H}) .{ }^{13} \mathrm{C}-\mathrm{NMR} \delta[\mathrm{ppm}]=29,2 ; 29,4 ; 31,0 ; 33,2(\mathrm{C}-18) ; 35,2(2 \mathrm{C}) ; 40,8 ; 41,9 ; 44,5$ (C-13); 47,6; 52,7; 55,6 (3-OMe); 77,6 (C-17); 79,9 (C-16a); 112,0 (C-2); 113,8 (C-4); 127,7 (C-1); 133,5 (C-10); 138,8 (C-5); 157,6 (C-3). MS (70 eV); m/z (\%): 313 (100, M $\left.{ }^{+}\right), 186(22)$, 173 (18), 84 (14).

\section{8}

${ }^{1} \mathrm{H}-\mathrm{NMR}\left(500 \mathrm{MHz}, \mathrm{CDCl}_{3}\right): \delta[\mathrm{ppm}]=1,07\left(\mathrm{~s}, 3 \mathrm{H}, 18-\mathrm{H}_{3}\right) ; 2,82\left(\mathrm{~m}, 2 \mathrm{H}, 6-\mathrm{H}_{2}\right) ; 3,04(\mathrm{~m}, 1 \mathrm{H}$, $16-\mathrm{H}) ; 3,47(\mathrm{t}, 1 \mathrm{H}, J=7,6 \mathrm{~Hz})$ és 3,77 (m, 1H): 16a-H $\mathrm{H}_{2}$; 3,78 (s, 3H, 3-OMe); 3,84 (d, 1H, $J=$ $8,6 \mathrm{~Hz}, 17-\mathrm{H}) ; 6,62$ (d, 1H, $J=2,5 \mathrm{~Hz}, 4-\mathrm{H}) ; 6,72$ (dd, 1H, $J=8,6 \mathrm{~Hz}, J=2,5 \mathrm{~Hz}, 2-\mathrm{H}) ; 7,24$ $(\mathrm{d}, 1 \mathrm{H}, J=8,6 \mathrm{~Hz}, 1-\mathrm{H}) .{ }^{13} \mathrm{C}-\mathrm{NMR} \delta[\mathrm{ppm}]=24,9(\mathrm{C}-18) ; 27,6 ; 28,9 ; 30,9 ; 34,1 ; 36,6 ; 40,9$; 42,4; 43,8 (C-13); 47,6; 54,3; 55,6 (3-OMe); 69,6 (C-17); 77,7 (C-16a); 112,1 (C-2); 114,0 (C-4); 127,3 (C-1); 132,9 (C-10); 138,6 (C-5); 157,9 (C-3). MS (70 eV); m/z (\%): 313 (100, $\mathrm{M}^{+}$), 240 (14), 227 (19), 225 (18), 173 (28), 147 (16), 84 (11). 
${ }^{1} \mathrm{H}-\mathrm{NMR}\left(500 \mathrm{MHz}, \mathrm{CDCl}_{3}\right): \delta[\mathrm{ppm}]=1,07$ (s, 3H, 18- $\left.\mathrm{H}_{3}\right) ; 2,57$ (s, 3H, N-Me); 2,82 (m, 2H, $\left.6-\mathrm{H}_{2}\right) ; 3,19(\mathrm{~m}, 1 \mathrm{H}, 16-\mathrm{H}) ; 3,36(\mathrm{~d}, 1 \mathrm{H}, J=9,5 \mathrm{~Hz}, 17-\mathrm{H}) ; 3,57$ (dd, $1 \mathrm{H}, J=8,4 \mathrm{~Hz}, J=2,9$ $\mathrm{Hz}$ ) és 4,11 (t, 1H, $J=8,4 \mathrm{~Hz}): 16 \mathrm{a}-\mathrm{H}_{2} ; 3,78(\mathrm{~s}, 3 \mathrm{H}, 3-\mathrm{OMe}) ; 6,62(\mathrm{~d}, 1 \mathrm{H}, J=2,6 \mathrm{~Hz}, 4-\mathrm{H})$; $6,72(\mathrm{dd}, 1 \mathrm{H}, J=8,6 \mathrm{~Hz}, J=2,6 \mathrm{~Hz}, 2-\mathrm{H}) ; 7,24(\mathrm{~d}, 1 \mathrm{H}, J=8,6 \mathrm{~Hz}, 1-\mathrm{H}) .{ }^{13} \mathrm{C}-\mathrm{NMR} \delta$ [ppm] $=$ 25,4 (C-18); 27,0; 28,4; 30,4; 33,6; 35,7; 40,5; 42,0; 43,0 (C-13); 45,6; 45,7; 54,5; 55,2 (3OMe); 71,3 (C-16a); 76,8 (C-17); 111,7 (C-2); 113,6 (C-4); 126,8 (C-1); 132,5 (C-10); 138,2 (C-5); 157,5 (C-3). MS (70 eV); m/z (\%): $327\left(100, \mathrm{M}^{+}\right), 98(74)$.

\section{II. melléklet}

A 135-ös vegyület kristálytani adatai

Crystal data and structure refinement:

\begin{tabular}{|c|c|}
\hline Empirical formula & $\mathrm{C}_{20} \mathrm{H}_{27} \mathrm{NO}_{2}$ \\
\hline Formula weight & 313.44 \\
\hline Temperature & $100(2) \mathrm{K}$ \\
\hline Space group & $P 1$ with 4 molecules per asymmetric unit \\
\hline Unit cell dimensions & 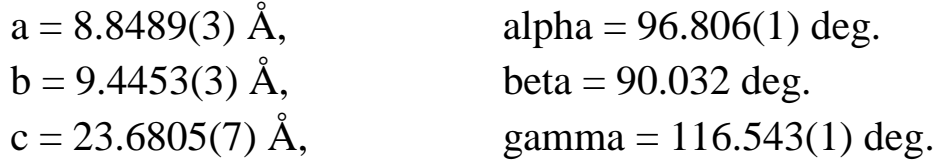 \\
\hline Volume, Z & $1754.9(1) \AA^{3}$ \\
\hline Density (calculated) & $1.186 \mathrm{~g} / \mathrm{cm}^{3}$ \\
\hline Crystal size & $0.30 \times 0.20 \times 0.20 \mathrm{~mm}^{3}$ \\
\hline Reflections collected & 23124 \\
\hline Refinement method & Full-matrix least-squares on $\mathrm{F}^{2}$ \\
\hline Goodness-of-fit on $\mathrm{F}^{2}$ & 1.038 \\
\hline \multicolumn{2}{|c|}{ Final $\mathrm{R}$ indices $[\mathrm{l}>2 \operatorname{sigma}(\mathrm{I})] \mathrm{R} 1=0.0259, \mathrm{wR} 2=0.0630$} \\
\hline \multicolumn{2}{|c|}{ Absolute structure parameter $-0.1(1)$} \\
\hline Largest diff. Peak and & 0.154 and $-0.170 \mathrm{e}^{-3}$ \\
\hline
\end{tabular}

III. Melléklet

A vegyületek NMR- és MS-adatai.

\section{5a}

${ }^{1} \mathrm{H}-\mathrm{NMR}\left(500 \mathrm{MHz}, \mathrm{CDCl}_{3}\right): \delta[\mathrm{ppm}]=1,38\left(\mathrm{~s}, 3 \mathrm{H}, 18-\mathrm{H}_{3}\right) ; 2,87\left(\mathrm{~m}, 2 \mathrm{H}, 6-\mathrm{H}_{2}\right) ; 3,42(\mathrm{dd}$, $1 \mathrm{H}, J=9,9 \mathrm{~Hz}, J=8,0 \mathrm{~Hz})$ és $3,80(\mathrm{dd}, 1 \mathrm{H}, J=9,9 \mathrm{~Hz}, J=2,2 \mathrm{~Hz}): 16 \mathrm{a}-\mathrm{H}_{2} ; 3,44(\mathrm{~d}, 1 \mathrm{H}, J=$ $8,6 \mathrm{~Hz}, 17 \mathrm{a}-\mathrm{H}) ; 3,78$ (s, 3H, 3-OMe); 4,33 (t, 1H, $\left.J=8,0 \mathrm{~Hz}, 4^{\prime}-\mathrm{H}\right) ; 5,09$ (d, 1H, $J=8,0 \mathrm{~Hz}$, 
3'-H); 6,64 (d, 1H, $J=2,4 \mathrm{~Hz}, 4-\mathrm{H}) ; 6,73$ (dd, 1H, $J=8,6 \mathrm{~Hz}, J=2,4 \mathrm{~Hz}, 2-\mathrm{H})$; 7,23-7,26 és 7,46 (átfedő multiplettek, 5H, 1-, 2"-, 3"-, 5"-, 6"-H); 7,40 (t, 1H, J=7,3 Hz, 4"-H). ${ }^{13} \mathrm{C}-\mathrm{NMR}$ $\delta[\mathrm{ppm}]=26,4 ; 27,4 ; 27,7 ; 29,8 ; 34,3$ (C-18); 34,9; 36,4; 36,6; 38,3; 42,0; 45,0; 50,3; 55,2; 55,6; 74,6 (C-17a); 77,3 (C-3'); 111,9 (C-2); 113,4 (C-4); 126,4 és 129,2 (2x2C, C-2”, -3”, 5", -6"); 126,7 (C-1); 129,0 (C-4"); 131,1 és 132,3 (2C, C-1" és C-10); 137,6 (C-5); 157,8 (C$3) ; 170,8$ és 173,6 (2C, C-2' és C-5'). MS (70 eV); $m / z(\%): 566(10), 564\left(10, \mathrm{M}^{+}\right), 470$ (26), 468 (26), 454 (31), 295 (41), 119 (50), 93 (100).

\section{5b}

${ }^{1} \mathrm{H}-\mathrm{NMR}\left(500 \mathrm{MHz}, \mathrm{CDCl}_{3}\right): \delta[\mathrm{ppm}]=1,36\left(\mathrm{~s}, 3 \mathrm{H}, 18-\mathrm{H}_{3}\right) ; 2,54(\mathrm{~m}, 1 \mathrm{H}, 16-\mathrm{H}) ; 2,87(\mathrm{~m}$, $\left.2 \mathrm{H}, 6-\mathrm{H}_{2}\right) ; 3,26(\mathrm{t}, 1 \mathrm{H}, J=8.7 \mathrm{~Hz})$ és $3,56(\mathrm{~m}, 1 \mathrm{H}): 16 \mathrm{a}-\mathrm{H}_{2} ; 3,42(\mathrm{~d}, 1 \mathrm{H}, J=8,5 \mathrm{~Hz}, 17 \mathrm{a}-\mathrm{H})$; 3,73 (s, 3H, 3-OMe); 4,26 (t, 1H, $J=8,5 \mathrm{~Hz}, 4$ '-H); 4,96 (d, 1H, $J=8,5 \mathrm{~Hz}, 3$ '-H); 6,62 (d, $1 \mathrm{H}, J=2,4 \mathrm{~Hz}, 4-\mathrm{H}) ; 6,71$ (dd, $1 \mathrm{H}, J=8,5 \mathrm{~Hz}, J=2,4 \mathrm{~Hz}, 2-\mathrm{H}) ; 7,21$ (d, 2H, $J=7,3 \mathrm{~Hz}, 2$ '”és 6"-H); 7,26 (d, 1H, $J=8,5 \mathrm{~Hz}, 1-\mathrm{H}) ; 7,38(\mathrm{t}, 1 \mathrm{H}, J=7,3 \mathrm{~Hz}, 4$ "-H); 7,44 (t, 2H, $J=7,3 \mathrm{~Hz}$, 3 "- és 5 "-H). ${ }^{13} \mathrm{C}-\mathrm{NMR} \delta[\mathrm{ppm}]=10,4(\mathrm{C}-16 \mathrm{a}) ; 27,4 ; 27,7 ; 28,2 ; 29,8 ; 34,3(\mathrm{C}-18) ; 36,3(\mathrm{C}-$ 13); 36,7; 38,5; 42,0; 45,2; 50,4 (C-4'); 55,0 (C-16); 55,2 (3-OMe); 74,6 (C-17a); 77,2 (C-3'); 111,9 (C-2); 113,4 (C-4); 126,4 (2C, C-2" és C-6"); 126,7 (C-1); 129,0 (C-4”); 129,2 (2C, C3" és C-5"); 131,1 (C-1"); 132,3 (C-10); 137,7 (C-5); 157,8 (C-3); 170,8 és 173,7 (2C, C-2' és C-5'). MS (70 eV); m/z (\%): $612\left(\mathrm{M}^{+}, 14\right), 471$ (21), 253 (52), 173 (100).

\section{6a}

${ }^{1} \mathrm{H}-\mathrm{NMR}\left(500 \mathrm{MHz}, \mathrm{CDCl}_{3}\right): \delta[\mathrm{ppm}]=1,22\left(\mathrm{~s}, 3 \mathrm{H}, 18-\mathrm{H}_{3}\right) ; 2,78\left(\mathrm{~m}, 1 \mathrm{H}, 4{ }^{\prime}-\mathrm{H}\right) ; 2,88(\mathrm{~m}, 2 \mathrm{H}$, $\left.6-\mathrm{H}_{2}\right) ; 3,52(\mathrm{dd}, 1 \mathrm{H}, J=10,1 \mathrm{~Hz}, J=7,3 \mathrm{~Hz})$ és $3,74(\mathrm{~m}, 1 \mathrm{H}): 16 \mathrm{a}-\mathrm{H}_{2} ; 3,54(\mathrm{~d}, 1 \mathrm{H}, J=9,2$ $\mathrm{Hz}, 17 \mathrm{a}-\mathrm{H}) ; 3,77$ (s, 3H, 3-OMe); 5,20 (d, 1H, $J=8,0 \mathrm{~Hz}, 3$ '-H); 6,64 (d, 1H, $J=2,2 \mathrm{~Hz}, 4-$ $\mathrm{H}) ; 6,72(\mathrm{dd}, 1 \mathrm{H}, J=8,6 \mathrm{~Hz}, J=2,2 \mathrm{~Hz}, 2-\mathrm{H}) ; 7,20$ (d, $1 \mathrm{H}, J=8,6 \mathrm{~Hz}, 1-\mathrm{H}) ; 7,29$ (d, 2H, $J=$ 7,8 Hz, 2"-, 6"-H); 7,48 (t, 2H, $J=7,8 \mathrm{~Hz}, 3$ "'- 5"-H); 7,41 (t, $1 \mathrm{H}, J=7,8 \mathrm{~Hz}, 4$ "'-H). ${ }^{13} \mathrm{C}-$ NMR $\delta$ [ppm] $=21,3(\mathrm{C}-18) ; 25,3 ; 26,5 ; 28,2 ; 29,8 ; 35,4 ; 37,2 ; 37,4 ; 38,4 ; 41,1 ; 43,2 ; 48,5$ $\left(\mathrm{C}-4\right.$ '); 55,2 (3- $\left.\mathrm{OCH}_{3}\right) ; 61,2(\mathrm{C}-16) ; 77,3$ (C-17a); 77,9 (C-3'); 111,7 (C-2); 113,5 (C-4); 126,2 és 128,9 (2x1C, C-1 és C-4"); 126,3 és 129,2 (2x2C, C-2",3",5”,6”); 131,1 és 131,9: C1" és C-10; 137,5 (C-5); 157,6 (C-3); 170,9 és 173,2 (2C, C-2'és -5'). MS (70 eV); $\mathrm{m} / \mathrm{z}(\%)$ : 566 (4), 564 (6, M ), 468 (38), 449 (30), 293 (100), 278 (62), 173 (37), 95 (47), 93 (47), 81 (38), 79 (38).

\section{6b}

${ }^{1} \mathrm{H}-\mathrm{NMR}\left(500 \mathrm{MHz}, \mathrm{CDCl}_{3}\right): \delta[\mathrm{ppm}]=1,23\left(\mathrm{~s}, 3 \mathrm{H}, 18-\mathrm{H}_{3}\right) ; 2,88\left(\mathrm{~m}, 2 \mathrm{H}, 6-\mathrm{H}_{2}\right) ; 3,41$ (dd, $1 \mathrm{H}, J=10,0 \mathrm{~Hz}, J=6,7 \mathrm{~Hz})$ és $3,51(\mathrm{~m}, 1 \mathrm{H}): 16 \mathrm{a}-\mathrm{H}_{2} ; 3,55(\mathrm{~d}, 1 \mathrm{H}, J=9,0 \mathrm{~Hz}, 17 \mathrm{a}-\mathrm{H}) ; 3,73$ (d, $1 \mathrm{H}, J=8,5 \mathrm{~Hz}, 4$ '-H); 3,77 (s, 1H, 3-OMe); 5,18 (d, 1H, $J=8,5 \mathrm{~Hz}, 3$ '-H); 6,63 (d, 1H, $J$ $=2,0 \mathrm{~Hz}, 4-\mathrm{H}) ; 6,72(\mathrm{dd}, 1 \mathrm{H}, J=8,4 \mathrm{~Hz}, J=2,0 \mathrm{~Hz}, 2-\mathrm{H}) ; 7,20(\mathrm{~d}, 1 \mathrm{H}, J=8,6 \mathrm{~Hz}, 1-\mathrm{H})$; $7,29(\mathrm{~d}, 2 \mathrm{H}, J=7,6 \mathrm{~Hz}, 2$ "- és 6"-H); 7,41 (t, 1H, $J=7,6 \mathrm{~Hz}, 4$ "-H ); 7,48 (t, 2H, $J=7,6 \mathrm{~Hz}$, 3 "- és 5 "'-H ). ${ }^{13} \mathrm{C}-\mathrm{NMR} \delta[\mathrm{ppm}]=11,0(\mathrm{C}-16 \mathrm{a}) ; 21,4(\mathrm{C}-18) ; 25,3 ; 26,6 ; 29,8 ; 30,1 ; 37,3$; 
37,4; 38,4; 41,3; 43,3; 48,7 (C-4'); 55,2 (3-OCH $)$; 60,4 (C-16); 77,3 (C-17a); 77,9 (C-3'); 111,8 (C-2); 113,5 (C-4); 126,2 (C-1); 126,3 (2C, C-2" és C-6”); 128,9 (C-4”); 129,2 (2C, C3" és C-5"); 131,2 (C-1"); 131,9 (C-10); 137,5 (C-5); 157,7 (C-3); 170,8 és 173,2 (2C, C-2' és C-5'). MS (70 eV); $m / z(\%): 612\left(10, \mathrm{M}^{+}\right), 566(23), 173(100)$.

\section{8}

${ }^{1} \mathrm{H}-\mathrm{NMR}\left(500 \mathrm{MHz}, \mathrm{CDCl}_{3}\right): \delta[\mathrm{ppm}]=1,03$ (s, 3H) és 1,09 (s, 3H): 18- $\mathrm{H}_{3}$ és 18 '- $\mathrm{H}_{3} ; 2,85$ $\left(\mathrm{m}, 4 \mathrm{H}, 6-\mathrm{H}_{2}\right.$ és 6'- $\left.\mathrm{H}_{2}\right) ; 2,92(\mathrm{~m}, 1 \mathrm{H}, 16-\mathrm{H}) ; 3,45-3,50(\mathrm{dd}, 1 \mathrm{H} J=10,0 \mathrm{~Hz}, J=7,6 \mathrm{~Hz})$ és 3,52-3,57 (dd, $1 \mathrm{H}, J=10,0 \mathrm{~Hz}, J=7,6 \mathrm{~Hz}): 16 \mathrm{a}-\mathrm{H}_{2} ; 3,66-3,71(\mathrm{td}, 2 \mathrm{H}, J=10,0 \mathrm{~Hz}, J=1,8$ $\mathrm{Hz}, 16 \mathrm{a}$ '- $\left.\mathrm{H}_{2}\right) ; 3,77$ (s, 6H, 3-OCH $\left.\mathrm{OCe}_{3} 3^{\prime}-\mathrm{OCH}_{3}\right) ; 3,86\left(\mathrm{~m}, 1 \mathrm{H}, 16^{\prime}-\mathrm{H}\right) ; 4,25(\mathrm{~s}, 1 \mathrm{H}, 17 \mathrm{a}-\mathrm{H})$; 4,94 (s, 1H, 17a'-H); 6,62 (d, 2H, $J=2,4 \mathrm{~Hz}$, 4-H és 4'-H); 6,71 (dd, 2H, $J=8,6 \mathrm{~Hz}, J=2,4$ $\mathrm{Hz}, 2-\mathrm{H}$ és 2 '-H); 7,17-7,21 (átfedő multiplettek, $2 \mathrm{H}, 1-\mathrm{H}$ és 1 '-H). ${ }^{13} \mathrm{C}-\mathrm{NMR} \delta[\mathrm{ppm}]=12,9$ és 17,2 (C-18 és C-18'); 25,3; 25,5; 26,2; 26,4; 28,4; 29,1; 29,8; 29,9; 33,5; 34,6; 35,1; 35,2; 37,$6 ; 38,4 ; 39,7 ; 39,4 ; 40,4 ; 43,1 ; 43,2 ; 46,2 ; 55,0$ (C-16); 55,2 (2C, 3- $\mathrm{OCH}_{3}$ és 3'- $\left.\mathrm{OCH}_{3}\right)$; 62,8 (C-16a); 92,2 és 96,5 (C-17a és C-17a'); 111,7 és 111,8 (C-2 és C-2'); 113,5 (2C, C-4 és C-4'); 126,2 (2C, C-1 és C-1'); 132,1 és 132,4 (C-10 és C-10'); 137,5 és 137,7 (C-5 és C-5'); 157,6 és 157,7 (C-3 és C-3'). MS (70 eV); $m / z(\%)$ : $784\left(10, \mathbf{M}^{+}\right)$.

\section{Melléklet}

A 145a vegyület kristálytani adatai

Crystal data and structure refinement:

\begin{tabular}{|c|c|}
\hline Empirical formula & $\mathrm{C}_{30} \mathrm{H}_{33} \mathrm{BrN}_{2} \mathrm{O}_{4}$ \\
\hline Formula weight & 565.49 \\
\hline Temperature & $100(2) \mathrm{K}$ \\
\hline Space group & $\mathrm{P} 2(1) 2(1) 2(1)$ \\
\hline Unit cell dimensions & $\begin{array}{l}\mathrm{a}=13.703(3) \AA \\
\mathrm{b}=27.097(5) \AA \\
\mathrm{c}=29.098(6) \AA\end{array}$ \\
\hline Volume, Z & $10805(4) \AA^{3}$ \\
\hline Density (calculated) & $1.391 \mathrm{~g} / \mathrm{cm}^{3}$ \\
\hline Absorption coefficient & $2.381 \mathrm{~mm}^{-1}$ \\
\hline Crystal size & $0.20 \times 0.10 \times 0.10 \mathrm{~mm}^{3}$ \\
\hline Reflections collected & 117098 \\
\hline Refinement method & Full-matrix least-squares on $\mathrm{F}^{2}$ \\
\hline Goodness-of-fit on $\mathrm{F}^{2}$ & 1.042 \\
\hline \multirow{2}{*}{\multicolumn{2}{|c|}{$\begin{array}{l}\text { Final } R \text { indices }[1>2 \operatorname{sigma}(I)] R 1=0.0251, w R 2=0.0572 \\
\text { Absolute structure parameter }-0.031(6)\end{array}$}} \\
\hline & \\
\hline Largest diff. Peak and 1 & 0.464 and $-0.333 \mathrm{e}^{-3}$ \\
\hline
\end{tabular}


V. Melléklet

A vegyületek NMR- és MS-adatai.

\section{3a}

${ }^{1} \mathrm{H}-\mathrm{NMR}\left(500 \mathrm{MHz}, \mathrm{CDCl}_{3}\right): \delta$ [ppm]: 1,16 (s, 3H, 18- $\left.\mathrm{H}_{3}\right) ; 2,86\left(\mathrm{~m}, 2 \mathrm{H}, 6-\mathrm{H}_{2}\right) ; 3,45(\mathrm{~m}, 1 \mathrm{H}$, 16-H); 3,66-3,70 (átfedő multiplettek, $\left.2 \mathrm{H}, 16 \mathrm{a}-\mathrm{H}_{2}\right) ; 3,76\left(\mathrm{~s}, 3 \mathrm{H}, 3-\mathrm{OCH}_{3}\right) ; 5,17(\mathrm{~s}, 1 \mathrm{H}, 17 \mathrm{a}-$ $\mathrm{H}) ; 6,61$ (d, 1H, $J=2,3 \mathrm{~Hz}, 4-\mathrm{H}) ; 6,65$ (dd, 1H, $J=8,6 \mathrm{~Hz}, J=2,3 \mathrm{~Hz}, 2-\mathrm{H}) ; 7,03$ (d, 1H, $J=$ 8,6 Hz, 1-H); 7,29 (d, 2H, $J=7,3 \mathrm{~Hz}, 2$ '-H és 6'-H); 7,42 (t, 1H, $\left.J=7,3 \mathrm{~Hz}, 4^{\prime}-\mathrm{H}\right) ; 7,47$ (t, $2 \mathrm{H}, J=7,3 \mathrm{~Hz}, 3^{\prime}$-H és 5 '-H); ${ }^{13} \mathrm{C}-\mathrm{NMR} \delta$ [ppm]: 18,6 (C-18); 25,0; 26,5; 28,3; 29,8; 35,5; 35,$6 ; 38,8 ; 38,9(\mathrm{C}-13) ; 39,7 ; 42,7 ; 55,2\left(3-\mathrm{OCH}_{3}\right) ; 63,2(\mathrm{C}-16) ; 86,0(\mathrm{C}-17 \mathrm{a}) ; 111,7$ (C-2); 113,5 (C-4); 126,0 (C-1); 128,0 (2C, C-2' és C-6'); 128,8 (C-4'); 129,9 (2C: C-3'és C-5'); 131,5 (C-10); 137,5 és 138,9 (C-5 és C-1'); 157,7 (C-3); 160,6 (NCO). MS pozitív üzemmód: $467\left(12 \%,\left[\mathrm{M}-\mathrm{CO}_{2}\right]^{+}\right) ; 392\left(63 \%,\left[\mathrm{M}-\mathrm{CO}_{2}-\mathrm{C}_{6} \mathrm{H}_{5}\right]^{+}\right)$.

\section{$153 b$}

${ }^{1} \mathrm{H}-\mathrm{NMR}\left(500 \mathrm{MHz}, \mathrm{CDCl}_{3}\right): \delta$ [ppm]: $1,17\left(\mathrm{~s}, 3 \mathrm{H}, 18-\mathrm{H}_{3}\right) ; 2,85\left(\mathrm{~m}, 2 \mathrm{H}, 6-\mathrm{H}_{2}\right) ; 3,05(\mathrm{~m}, 1 \mathrm{H}$, $16-\mathrm{H}) ; 3,51\left(\mathrm{~m}, 2 \mathrm{H}, 16 \mathrm{a}-\mathrm{H}_{2}\right) ; 3,76\left(\mathrm{~s}, 3 \mathrm{H}, 3-\mathrm{OCH}_{3}\right) ; 5,15(\mathrm{~s}, 1 \mathrm{H}, 17 \mathrm{a}-\mathrm{H}) ; 6,61(\mathrm{~d}, 1 \mathrm{H}, J=2,4$ $\mathrm{Hz}, 4-\mathrm{H}) ; 6,65$ (dd, 1H, $J=8,6 \mathrm{~Hz}, J=2,4 \mathrm{~Hz}, 2-\mathrm{H}$ ); 7,02 (d, 1H, $J=8,6 \mathrm{~Hz}, 1-\mathrm{H}) ; 7,29$ (d, $2 \mathrm{H}, J=7,2 \mathrm{~Hz}, 2$ '-H és 6'-H); 7,41 (t, 1H, $J=7,2 \mathrm{~Hz}, 4$ '-H); 7,47 (t, 2H, $J=7,2 \mathrm{~Hz}, 3$ '-H és $\left.5^{\prime}-\mathrm{H}\right) .{ }^{13} \mathrm{C}-\mathrm{NMR} \delta$ [ppm]: 11,1 (C-16a); 18,8 (C-18); 25,0; 26,5; 29,8; 30,3; 35,5; 38,8; 39,0 (C-13); 39,8; 42,7; 55,2 (3-OCH $)$; 62,5 (C-16); 86,0 (C-17a); 111,7 (C-2); 113,5 (C-4); 126,0 és 128,8 (C-1 és C-4'); 129,9 (2C: C-3' és C-5'); 131,5 (C-10); 137,5 és 138,9 (C-5 és C-1'); 157,7 (C-3); 160,6 (NCO). MS pozitív üzemmód: $515\left(5 \%,\left[\mathrm{M}-\mathrm{CO}_{2}\right]^{+}\right) ; 440\left(31 \%,\left[{\mathrm{M}-\mathrm{CO}_{2}-}^{-}\right.\right.$ $\left.\left.\left.\mathrm{C}_{6} \mathrm{H}_{5}\right]^{+}\right) ; 387(100 \% \text {, [M-CO } 2-\mathrm{I}]^{+}\right)$.

\section{$154 a$}

${ }^{1} \mathrm{H}-\mathrm{NMR}\left(500 \mathrm{MHz}, \mathrm{CDCl}_{3}\right): \delta$ [ppm]: $1,15\left(\mathrm{~s}, 3 \mathrm{H}, 18-\mathrm{H}_{3}\right) ; 2,86\left(\mathrm{~m}, 2 \mathrm{H}, 6-\mathrm{H}_{2}\right) ; 3,42(\mathrm{~m}, 1 \mathrm{H}$, 16-H); 3,65-3,72 (átfedő multiplettek, 2H, 16a-H $)$; 3,76 (s, 3H, 3-OCH $\left.{ }_{3}\right) ; 3,84$ (s, 3H, 4'$\left.\mathrm{OCH}_{3}\right) ; 5,07(\mathrm{~s}, 1 \mathrm{H}, 17 \mathrm{a}-\mathrm{H}) ; 6,61(\mathrm{~d}, 1 \mathrm{H}, J=2,6 \mathrm{~Hz}, 4-\mathrm{H}) ; 6,66(\mathrm{dd}, 1 \mathrm{H}, J=8,6 \mathrm{~Hz}, J=2,6$ $\mathrm{Hz}, 2-\mathrm{H}) ; 6,96(\mathrm{~d}, 2 \mathrm{H}, J=8,9 \mathrm{~Hz}, 3$ '-H és 5'-H); 7,05 (d, 1H, $J=8,6 \mathrm{~Hz}, 1-\mathrm{H}) ; 7,20$ (d, 2H, $J$ $=8,9 \mathrm{~Hz}, 2^{\prime}$-H és $\left.6{ }^{\prime}-\mathrm{H}\right) .{ }^{13} \mathrm{C}-\mathrm{NMR} \delta[\mathrm{ppm}]: 18,7$ (C-18); 25,0; 26,5; 28,4; 29,8; 35,2; 35,6; 38,8; 38,9 (C-13); 39,8; 42,8; 55,2 (3- $\left.\mathrm{OCH}_{3}\right) ; 55,5\left(4^{\prime}-\mathrm{OCH}_{3}\right) ; 63,1$ (C-16); 85,9 (C-17a); 111,7 (C-2); 113,6 (C-4); 115,2 (2C: C-3'és C-5'); 126,0 (C-1); 131,3 és 131,6 (C-1' és C10); 137,5 (C-5); 157,7 (C-3); 159,7 (C-4'); 160,8 (NCO). MS pozitív üzemmód: 497 (7\%, $\left.\left[\mathrm{M}-\mathrm{CO}_{2}\right]^{+}\right) ; 417\left(17 \%,\left[\mathrm{M}-\mathrm{CO}_{2}-\mathrm{Br}\right]^{+}\right) ; 392\left(56 \%,\left[\mathrm{M}-\mathrm{CO}_{2}-\mathrm{C}_{7} \mathrm{H}_{7}\right]^{+}\right) ; 296\left(100 \%,\left[\mathrm{M}-\mathrm{CO}_{2}-\right.\right.$ $\left.\mathrm{CH}_{2} \mathrm{Br}-\mathrm{C}_{7} \mathrm{H}_{7}\right]^{+}$). 
${ }^{1} \mathrm{H}-\mathrm{NMR}\left(500 \mathrm{MHz}, \mathrm{CDCl}_{3}\right): \delta[\mathrm{ppm}]: 1,16\left(\mathrm{~s}, 3 \mathrm{H}, 18-\mathrm{H}_{3}\right) ; 2,86\left(\mathrm{~m}, 2 \mathrm{H}, 6-\mathrm{H}_{2}\right) ; 3,04(\mathrm{~m}, 1 \mathrm{H}$, $16-\mathrm{H}) ; 3,50\left(\mathrm{~m}, 2 \mathrm{H}, 16 \mathrm{a}-\mathrm{H}_{2}\right) ; 3,76\left(\mathrm{~s}, 3 \mathrm{H}, 3-\mathrm{OCH}_{3}\right) ; 3,84\left(\mathrm{~s}, 3 \mathrm{H}, 4^{\prime}-\mathrm{OCH}_{3}\right) ; 5,05(\mathrm{~s}, 1 \mathrm{H}, 17 \mathrm{a}-$ $\mathrm{H}) ; 6,62(\mathrm{~s}, 1 \mathrm{H}, 4-\mathrm{H}) ; 6,66$ (d, 1H, $J=8,6 \mathrm{~Hz}, 2-\mathrm{H}) ; 6,96$ (d, 2H, $J=8,4 \mathrm{~Hz}, 3$ '-H és 5'-H); $7,05$ (d, $1 \mathrm{H}, J=8,6 \mathrm{~Hz}, 1-\mathrm{H}) ; 7,19$ (d, $2 \mathrm{H}, J=8,4 \mathrm{~Hz}, 2$ '-H és 6'-H ). ${ }^{13} \mathrm{C}-\mathrm{NMR} \delta$ [ppm]: 11,0 (C-16a); 18,8 (C-13); 25,0; 26,5; 29,8; 30,4; 35,2; 38,8; 38,9 (C-13); 39,8; 42,8; 55,2 (3$\left.\mathrm{OCH}_{3}\right) ; 55,5\left(4^{\prime}-\mathrm{OCH}_{3}\right) ; 62,4(\mathrm{C}-16) ; 85,9(\mathrm{C}-17 \mathrm{a}) ; 111,7(\mathrm{C}-2) ; 113,5(\mathrm{C}-4), 115,2$ (2C: C3'és C-5'); 126,0 (C-1); 131,3 és 131,5 (C-1'és C-10); 137,5 (C-5); 157,7 (C-3); 159,6 (C-4');

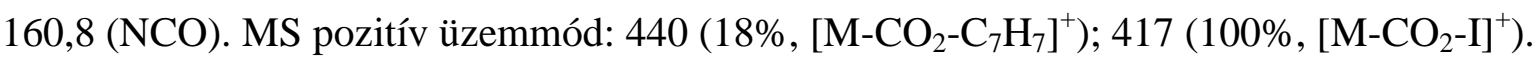

\section{$155 \mathbf{a}$}

${ }^{1} \mathrm{H}-\mathrm{NMR}\left(500 \mathrm{MHz}, \mathrm{CDCl}_{3}\right): \delta[\mathrm{ppm}]: 1,16\left(\mathrm{~s}, 3 \mathrm{H}, 18-\mathrm{H}_{3}\right) ; 2,86\left(\mathrm{~m}, 2 \mathrm{H}, 6-\mathrm{H}_{2}\right) ; 3,41(\mathrm{~m}, 1 \mathrm{H}$, 16-H); 3,63-3,70 (átfedő multiplettek, $\left.2 \mathrm{H}, 16 \mathrm{a}-\mathrm{H}_{2}\right) ; 3,76\left(\mathrm{~s}, 3 \mathrm{H}, 3-\mathrm{OCH}_{3}\right) ; 5,14(\mathrm{~s}, 1 \mathrm{H}, 17 \mathrm{a}-$ $\mathrm{H}) ; 6,62(\mathrm{~d}, 1 \mathrm{H}, J=2,2 \mathrm{~Hz}, 4-\mathrm{H}) ; 6,67(\mathrm{dd}, 1 \mathrm{H}, J=8,4 \mathrm{~Hz}, J=2,2 \mathrm{~Hz}, 2-\mathrm{H}) ; 7,06(\mathrm{~d}, 1 \mathrm{H}, J=$ $8,4 \mathrm{~Hz}, 1-\mathrm{H}) ; 7,24(\mathrm{~d}, 2 \mathrm{H}, J=8,4 \mathrm{~Hz}, 3$ '-H és 5'-H); 7,45 (d, 2H, $J=8,4 \mathrm{~Hz}, 2$ '-H és 6'H). ${ }^{13} \mathrm{C}-\mathrm{NMR} \delta$ [ppm]: 18,6 (C-18); 24,9; 26,5; 28,3; 29,8; 35,4; 35,9; 38,8; 39,0 (C-13); 39,8; 42,8; 55,2 (3- $\left.\mathrm{OCH}_{3}\right) ; 63,2$ (C-16); 85,9 (C-17a); 111,7 (C-2); 113,5 (C-4); 126,0 (C-1); 130,2 (2C, C-3'és C-5'); 131,3 (C-10); 134,7 (C-4'); 137,4 és 137,5 (C-1' és C-5); 157,7 (C-3); 160,4 (NCO). MS pozitív üzemmód: $421\left(35 \%,\left[\mathrm{M}-\mathrm{CO}_{2}-\mathrm{Br}\right]^{+}\right) ; 392\left(100 \%,\left[\mathrm{M}-\mathrm{CO}_{2}-\right.\right.$ $\left.\mathrm{C}_{6} \mathrm{H}_{4} \mathrm{Cl}\right]^{+}$).

\section{$155 b$}

${ }^{1} \mathrm{H}-\mathrm{NMR}\left(500 \mathrm{MHz}, \mathrm{CDCl}_{3}\right): \delta$ [ppm]: $1,17\left(\mathrm{~s}, 3 \mathrm{H}, 18-\mathrm{H}_{3}\right) ; 2,86\left(\mathrm{~m}, 2 \mathrm{H}, 6-\mathrm{H}_{2}\right) ; 3,02(\mathrm{~m}, 1 \mathrm{H}$, $16-\mathrm{H}) ; 3,50\left(\mathrm{~d}, 2 \mathrm{H}, J=4,2 \mathrm{~Hz}, 16 \mathrm{a}-\mathrm{H}_{2}\right) ; 3,76\left(\mathrm{~s}, 3 \mathrm{H}, 3-\mathrm{OCH}_{3}\right) ; 5,12(\mathrm{~s}, 1 \mathrm{H}, 17 \mathrm{a}-\mathrm{H}) ; 6,62(\mathrm{~d}$, $1 \mathrm{H}, J=2,3 \mathrm{~Hz}, 4-\mathrm{H}) ; 6,67$ (dd, $1 \mathrm{H}, J=8,5 \mathrm{~Hz}, J=2,3 \mathrm{~Hz}, 2-\mathrm{H}) ; 7,06$ (d, $1 \mathrm{H}, J=8,5 \mathrm{~Hz}, 1-$ $\mathrm{H}) ; 7,23$ (d, 2H, $J=7,7 \mathrm{~Hz}, 3$ '-H és 5 '-H); 7,44 (d, 2H, $J=7,7 \mathrm{~Hz}, 2$ '-H és 6 '-H). ${ }^{13} \mathrm{C}-\mathrm{NMR} \delta$ [ppm]: 10,8 (C-16a); 18,8 (C-18); 24,9; 26,5; 29,8; 30,3; 35,8; 38,8; 39,1 (C-13); 39,9; 42,8; 55,2 (3- $\left.\mathrm{OCH}_{3}\right) ; 62,5(\mathrm{C}-16) ; 85,9(\mathrm{C}-17 \mathrm{a}) ; 111,7$ (C-2); 113,5 (C-4); 126,0 (C-1); 130,2 (2C: C-3'és C-5'); 131,3 (C-10); 134,7 (C-4'); 137,4 és 137,6 (C-1' és C-5); 157,7 (C-3); 160,5 (NCO). MS pozitív üzemmód: $440\left(100 \%,\left[\mathrm{M}-\mathrm{CO}_{2}-\mathrm{C}_{6} \mathrm{H}_{5} \mathrm{Cl}\right]^{+}\right) ; 421\left(37 \%,\left[\mathrm{M}-\mathrm{CO}_{2}-\mathrm{I}\right]^{+}\right)$.

\section{6a}

${ }^{1} \mathrm{H}-\mathrm{NMR}\left(500 \mathrm{MHz}, \mathrm{CDCl}_{3}\right): \delta$ [ppm]: 1,16 (s, 3H, 18- $\left.\mathrm{H}_{3}\right) ; 2,85\left(\mathrm{~m}, 2 \mathrm{H}, 6-\mathrm{H}_{2}\right), 3,45(\mathrm{~m}, 1 \mathrm{H}$, 16-H); 3,65-3,72 (átfedő multiplettek, $\left.2 \mathrm{H}, 16 \mathrm{a}-\mathrm{H}_{2}\right) ; 5,02\left(\mathrm{~s}, 2 \mathrm{H}, 3-\mathrm{OCH}_{2}\right) ; 5,17$ (s, 1H, 17a$\mathrm{H}) ; 6,71(\mathrm{~s}, 1 \mathrm{H}, 4 \mathrm{H}) ; 6,73$ (d, 1H, $J=8,5 \mathrm{~Hz}, 2-\mathrm{H}) ; 7,03$ (d, 1H, $J=8,5 \mathrm{~Hz}, 1-\mathrm{H}) ; 7,30-7,33$ (átfedő multiplettek, 3H, 2'-H, 6'-H és 4'-H); 7,35-7,43 (átfedő multiplettek, 5H, 2"'-H, 3"'-H, 5"'-H, 6"-H, 4'-H); 7,47 (m, 2H, 3'-H és 5'-H). ${ }^{13} \mathrm{C}-\mathrm{NMR} \delta$ [ppm]: 18,6 (C-18); 24,6; 26,1; 27,$9 ; 29,4 ; 35,1 ; 35,2 ; 38,4 ; 38,5(\mathrm{C}-13) ; 39,3 ; 42,3 ; 62,8(\mathrm{C}-16) ; 69,5\left(\mathrm{OCH}_{2}\right) ; 85,5(\mathrm{C}-17 \mathrm{a})$; 112,1 (C-2); 114,2 (C-4); 126,0 (C-1); 127,4 (2C:C-2" és C-6”); 127,9 (C-4”); 128,5 (2C: C3" és C-5”); 128,8 (C-4'); 129,9 (2C: C-3' és C-5'); 131,8 (C-10); 137,2 (C-1"); 137,5 (C-5); 
138,8 (C-1'); 156,9 (C-3); 160,6 (NCO). MS pozitív üzemmód: 543 (20\%, [M-CO $\left.]^{+}\right) ; 429$ $\left(80 \%,\left[\mathrm{M}-\mathrm{Br}-\mathrm{C}_{6} \mathrm{H}_{5}\right]^{+}\right)$.

\section{6b}

${ }^{1} \mathrm{H}-\mathrm{NMR}\left(500 \mathrm{MHz}, \mathrm{CDCl}_{3}\right): \delta$ [ppm]: 1,17 (s, 3H, 18- $\left.\mathrm{H}_{3}\right) ; 2,85\left(\mathrm{~m}, 2 \mathrm{H}, 6-\mathrm{H}_{2}\right) ; 3,05(\mathrm{~m}, 1 \mathrm{H}$, $16-\mathrm{H}) ; 3,52\left(\mathrm{~m}, 2 \mathrm{H}, 16 \mathrm{a}-\mathrm{H}_{2}\right) ; 5,01\left(\mathrm{~s}, 2 \mathrm{H}, 3-\mathrm{OCH}_{2}\right) ; 5,15(\mathrm{~s}, 1 \mathrm{H}, 17 \mathrm{a}-\mathrm{H}) ; 6,70(\mathrm{~s}, 1 \mathrm{H}, 4 \mathrm{H})$; $6,73$ (d, 1H, $J=8,5 \mathrm{~Hz}, 2-\mathrm{H}) ; 7,03$ (d, 1H, $J=8,5 \mathrm{~Hz}, 1-\mathrm{H}$ ); 7,29-7,33 (átfedő multiplettek, $3 \mathrm{H}, 2^{\prime}-\mathrm{H}, 6$ '-H, 4'-H); 7,36-7,43 (átfedő multiplettek, 5H, 3'-H, 4'-H, 5'-H, 3'-H és 5'-H); 7,48 (m, 2H, 2"-H és 6"-H). ${ }^{13} \mathrm{C}-\mathrm{NMR} \delta$ [ppm]: 11,1 (C-16a); 18,8 (C-18); 25,0; 26,5; 29,8; 30,$3 ; 35,5 ; 38.8 ; 39,0(\mathrm{C}-13) ; 39,8 ; 42,7 ; 62,5(\mathrm{C}-16) ; 69,9\left(\mathrm{OCH}_{2}\right) ; 85,9(\mathrm{C}-17 \mathrm{a}) ; 112,5(\mathrm{C}-$ 2); 114,5 (C-4); 126,0 (C-1); 127,4 (2C: C-2" és C-6"); 127,9 (C-4"); 128,5 (2C: C-3" és C5"); 128,8 (C-4'); 129,9 (2C: C-3' és C-5'); 131,8 (C-10); 137,2 (C-1");137,6 (C-5); 138,9

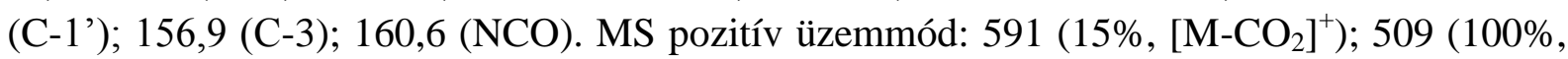
$\left.[\mathrm{M}-\mathrm{I}]^{+}\right)$.

\section{7a}

${ }^{1} \mathrm{H}-\mathrm{NMR}\left(500 \mathrm{MHz}, \mathrm{CDCl}_{3}\right): \delta$ [ppm]: $1,15\left(\mathrm{~s}, 3 \mathrm{H}, 18-\mathrm{H}_{3}\right) ; 2,85\left(\mathrm{~m}, 2 \mathrm{H}, 6-\mathrm{H}_{2}\right) ; 3,43(\mathrm{~m}, 1 \mathrm{H}$, 16-H); 3,64-3,71 (átfedő multiplettek, 2H, 16a- $\left.\mathrm{H}_{2}\right) ; 3,84$ (s, 3H, 4'- $\left.\mathrm{OCH}_{3}\right) ; 5,02$ (s, 2H, 3$\left.\mathrm{OCH}_{2}\right) ; 5,07(\mathrm{~s}, 1 \mathrm{H}, 17 \mathrm{a}-\mathrm{H}) ; 6,71(\mathrm{~s}, 1 \mathrm{H}, 4-\mathrm{H}) ; 6,74(\mathrm{~d}, 1 \mathrm{H}, J=8,4 \mathrm{~Hz}, 2-\mathrm{H}) ; 6,97(\mathrm{~d}, 2 \mathrm{H}, J=$ $8,6 \mathrm{~Hz}, 3$ '-H és 5'-H); 7,05 (d, 1H, $J=8,5 \mathrm{~Hz}, 1-\mathrm{H})$; 7,20 (m, 2H, 2'-H és 6'-H); 7,32 (m, 1H, 4 "-H); 7,38 (m, 2H, 3"-H és 5"-H); 7,41 (m, 2H, 2"-H és 6"-H). ${ }^{13} \mathrm{C}-\mathrm{NMR} \delta$ [ppm]: 18,7 (C$18) ; 24,6 ; 26,1 ; 28,0 ; 29,4 ; 34,8 ; 35,2 ; 38,4(2 \mathrm{C}) ; 39,3 ; 42,4 ; 55,1\left(4^{\prime}-\mathrm{OCH}_{3}\right) ; 62,7$ (C-16); 69,5 $\left(\mathrm{OCH}_{2}\right)$; 85,5 (C-17a); 112,5 (C-2); 114,6 (C-4); 115,2 (2C: C-3' és C-5'); 126,0 (C-1); 127,4 (2C: C-2" és C-6"); 127,9 (C-4”); 128,5 (2C: C-3" és C-5”); 131,2 (C-1'); 131,8 (C10); 137,2 (C-1”); 137,6 (C-5); 156,9 (C-3); 159,6 (C-4’); 160,8 (NCO). MS pozitív üzemmód: $573\left(10 \%,\left[\mathrm{M}-\mathrm{CO}_{2}\right]^{+}\right) ; 429\left(100 \%,\left[\mathrm{M}-\mathrm{Br}-\mathrm{C}_{7} \mathrm{H}_{7} \mathrm{O}\right]^{+}\right)$.

\section{$157 b$}

${ }^{1} \mathrm{H}-\mathrm{NMR}\left(500 \mathrm{MHz}, \mathrm{CDCl}_{3}\right): \delta$ [ppm]: 1,16 (s, 3H, 18- $\left.\mathrm{H}_{3}\right) ; 2,85\left(\mathrm{~m}, 2 \mathrm{H}, 6-\mathrm{H}_{2}\right) ; 3,04(\mathrm{~m}, 1 \mathrm{H}$, $16-\mathrm{H}) ; 3,51\left(\mathrm{~m}, 2 \mathrm{H}, 16 \mathrm{a}-\mathrm{H}_{2}\right) ; 3,84\left(\mathrm{~s}, 3 \mathrm{H}, 4^{\prime}-\mathrm{OCH}_{3}\right) ; 5,02\left(\mathrm{~s}, 2 \mathrm{H}, 3-\mathrm{OCH}_{2}\right) ; 5,06(\mathrm{~s}, 1 \mathrm{H}, 17 \mathrm{a}-$ $\mathrm{H}) ; 6,70$ (s, 1H, 4-H); 6,73 (d, 1H, J = 8,5 Hz, 2-H); 6,98 (m, 2H, 3'-H és 5'-H); 7,05 (d, 1H, $J=8,5 \mathrm{~Hz}, 1-\mathrm{H}) ; 7,19$ (m, 2H, 2'-H és 6'-H); 7,31 (m, 1H, 4'-H); 7,37 (t, 2H, $J=7,3 \mathrm{~Hz}, 3$ '”H és 5"-H); 7,41 (d, 2H, $J=7,3 \mathrm{~Hz}, 2$ "-H és 6 "-H). ${ }^{13} \mathrm{C}-\mathrm{NMR} \delta$ [ppm]: 11,1 (C-16a); 18,8 (C18); 24,9; 26,5; 29,8; 30,4; 35,2; 38,8; 38,9 (C-13); 39,8; 42,8; 55,5 (4'- $\left.\mathrm{OCH}_{3}\right) ; 62,4$ (C-16); 69,9 $\left(\mathrm{OCH}_{2}\right) ; 85,9(\mathrm{C}-17 \mathrm{a}) ; 112,5(\mathrm{C}-2) ; 114,6(\mathrm{C}-4) ; 115,1$ (2C: C-3' és C-5'); 126,0 (C-1); 127,4 (2C: C-2" és C-6"); 127,9 (C-4”); 128,5 (2C: C-3" és C-5"); 131,3 (C-1'); 131,8 (C10); 137,2 (C-1"); 137,6 (C-5); 156,9 (C-3); 159,6 (C-4'); 160,6 (NCO). MS pozitív üzemmód: $515\left(42 \%,\left[\mathrm{M}-\mathrm{CO}_{2}-\mathrm{C}_{7} \mathrm{H}_{7} \mathrm{O}\right]^{+}\right) ; 497$ (100\%).

\section{8a}

${ }^{1} \mathrm{H}-\mathrm{NMR}\left(500 \mathrm{MHz}, \mathrm{CDCl}_{3}\right): \delta$ [ppm]: 1,16 (s, 3H, 18- $\left.\mathrm{H}_{3}\right) ; 2,84\left(\mathrm{~m}, 2 \mathrm{H}, 6-\mathrm{H}_{2}\right) ; 3,41(\mathrm{~m}, 1 \mathrm{H}$, 16-H); 3,63-3,71 (átfedő multiplettek, 2H, 16a-H $)$; 5,02 (s, 2H, 3-OCH $)_{2} ; 5,14(\mathrm{~s}, 1 \mathrm{H}, 17 \mathrm{a}-$ 
$\mathrm{H}) ; 6,71(\mathrm{~s}, 1 \mathrm{H}, 4-\mathrm{H}) ; 6,74(\mathrm{~d}, 1 \mathrm{H}, J=8,4 \mathrm{~Hz}, 2-\mathrm{H}) ; 7,06(\mathrm{~d}, 1 \mathrm{H}, J=9,0 \mathrm{~Hz}, 1-\mathrm{H}) ; 7,25$ (d, $2 \mathrm{H}, J=7,8 \mathrm{~Hz}, 3$ '-H és 5'-H); 7,29-7,33 (átfedő multiplettek, 3H, 4'-H, 2'-H és 6'-H); 7,37 (m, 2H, 3"-H és 5"-H); 7,43 (m, 2H, 2"-H és 6"-H). ${ }^{13} \mathrm{C}-\mathrm{NMR} \delta$ [ppm]: 18,6 (C-18); 24,9; 26,$5 ; 28,3 ; 29,8 ; 35,4 ; 35,9 ; 38,8 ; 39,0(\mathrm{C}-13) ; 39,9 ; 42,8 ; 63,2(\mathrm{C}-16) ; 69,9\left(\mathrm{OCH}_{2}\right) ; 85,9(\mathrm{C}-$ 17a); 112,5 (C-2); 114,6 (C-4); 126,1 (C-1); 127,4 (2C: C-2” és C-6”); 127,9 (C-4”); 128,5 (2C: C-3" és C-5”); 130,2 (2C: C-3' és C-5'); 131,6 (C-10); 134,7 (C-4'); 137,1 (C-1”); 137,5 (2C: C-5 és C-1'); 157,0 (C-3); 160,4 (NCO). MS pozitív üzemmód: $621\left(100 \%, \mathrm{M}^{+}\right) ; 493$ $\left(55 \%,\left[\mathrm{M}-\mathrm{Cl}-\mathrm{CH}_{2} \mathrm{Br}\right]^{+}\right)$.

\section{$158 b$}

${ }^{1} \mathrm{H}-\mathrm{NMR}\left(500 \mathrm{MHz}, \mathrm{CDCl}_{3}\right): \delta$ [ppm]: $1,17\left(\mathrm{~s}, 3 \mathrm{H}, 18-\mathrm{H}_{3}\right) ; 2,85\left(\mathrm{~m}, 2 \mathrm{H}, 6-\mathrm{H}_{2}\right) ; 3,02(\mathrm{~m}, 1 \mathrm{H}$, $16-\mathrm{H}) ; 3,50\left(\mathrm{~m}, 2 \mathrm{H}, 16 \mathrm{a}-\mathrm{H}_{2}\right) ; 5,02\left(\mathrm{~s}, 2 \mathrm{H}, 3-\mathrm{OCH}_{2}\right) ; 5,12(\mathrm{~s}, 1 \mathrm{H}, 17 \mathrm{a}-\mathrm{H}) ; 6,70(\mathrm{~s}, 1 \mathrm{H}, 4-\mathrm{H})$; $6,74(\mathrm{~d}, 1 \mathrm{H}, J=8,5 \mathrm{~Hz}, 2-\mathrm{H}) ; 7,06(\mathrm{~d}, 1 \mathrm{H}, J=8,5 \mathrm{~Hz}, 1-\mathrm{H}) ; 7,23$ (d, 2H, $J=7,1 \mathrm{~Hz}, 3$ '-H és 5'-H); 7,31 (t, 1H, $J=6,9$ Hz, 4'-H); 7,37 (m, 2H, 2'-H és 6'-H); 7,41 (m, 2H, 3'-H és 5"'-H); 7,45 (m, 2H, 2"-H és 6"-H). ${ }^{13} \mathrm{C}-\mathrm{NMR} \delta$ [ppm] $55^{\circ} \mathrm{C}: 10,8$ (C-16a); 18,8 (C-18); 24,9; 26,5; 29,$8 ; 30,3 ; 35,8 ; 38,7 ; 39,1(\mathrm{C}-13) ; 39,9 ; 42,8 ; 62,5(\mathrm{C}-16) ; 69,9\left(\mathrm{OCH}_{2}\right) ; 85,9(\mathrm{C}-17 \mathrm{a}) ; 112,5$ (C-2); 114,6 (C-4); 126,1 (C-1); 127,4 (2C: C-2"és C-6"); 127,9 (C-4"); 128,5 (2C: C-3" és C-5”); 129,1 (2C: C-2' és C-6'); 130,2 (2C: C-3' és C-5'); 131,6 (C-10); 134,7 (C-4'); 137,1 (C-1”); 137,5 (2C: C-5 és C-1'); 156,9 (C-3); 160,5 (NCO). MS pozitív üzemmód: 625 (11\%, $\left.\left[\mathrm{M}-\mathrm{CO}_{2}\right]^{+}\right) ; 497\left(100 \%,\left[\mathrm{M}-\mathrm{CO}_{2}-\mathrm{I}\right]^{+}\right)$.

\section{Melléklet}

\section{A vegyületek NMR-adatai}

\section{2}

${ }^{1} \mathrm{H}-\mathrm{NMR}\left(500 \mathrm{MHz}, \mathrm{CDCl}_{3}\right): \delta[\mathrm{ppm}]=0,81\left(\mathrm{~s}, 3 \mathrm{H}, 18-\mathrm{H}_{3}\right) ; 2,85-2,97\left(\mathrm{~m}, 2 \mathrm{H}, 6-\mathrm{H}_{2}\right) ; 5,05$ $\left(\mathrm{s}, 2 \mathrm{H}, \mathrm{OCH}_{2}\right) ; 5,77(\mathrm{~m}, 1 \mathrm{H})$ és $5,93(\mathrm{~m}, 1 \mathrm{H}): 16-\mathrm{H}$ és $17-\mathrm{H} ; 6,75(\mathrm{~s}, 1 \mathrm{H}, 4-\mathrm{H}) ; 6,79(\mathrm{~d}, 1 \mathrm{H}, J$ $=8,5 \mathrm{~Hz}, 2-\mathrm{H}) ; 7,21(\mathrm{~d}, 1 \mathrm{H}, \mathrm{J}=8,5 \mathrm{~Hz}, 1-\mathrm{H}) ; 7,34\left(\mathrm{t}, 1 \mathrm{H}, J=7,1 \mathrm{~Hz}, 4^{\prime}-\mathrm{H}\right) ; 7,39$ (t, 2H, $J=$ $7,5 \mathrm{~Hz}, 3$ '-H és 5 '-H); 7,45 (t, 2H, $J=7,5 \mathrm{~Hz}, 2$ '-H és 6 '-H). ${ }^{13} \mathrm{C}-\mathrm{NMR} \delta[\mathrm{ppm}]=17,1(\mathrm{C}-$ $18) ; 26,6 ; 28,0 ; 29,8 ; 31,8 ; 35,9 ; 37,3 ; 44,6 ; 45,8(\mathrm{C}-13) ; 55,4 ; 70,0\left(\mathrm{OCH}_{2}\right) ; 112,2(\mathrm{C}-2)$; 114,8 (C-4); 126,0 (C-1); 127,4 (2C: C-2'és C-6'); 127,8 (C-4'); 128,5 (2C: C-3' és C-5'); 129,3 és 144,0 (C-16 és C-17); 133,4 (C-10); 137,3 (C-1'); 138,4 (C-5); 156,7 (C-3).

\section{3}

${ }^{1} \mathrm{H}-\mathrm{NMR}\left(500 \mathrm{MHz}, \mathrm{CDCl}_{3}\right): \delta[\mathrm{ppm}]=0,77\left(\mathrm{~s}, 3 \mathrm{H}, 18-\mathrm{H}_{3}\right) ; 2,86\left(\mathrm{~m}, 2 \mathrm{H}, 6-\mathrm{H}_{2}\right) ; 3,18(\mathrm{~m}, 1 \mathrm{H})$ és 3,41 (m, 1H): 16-H és 17-H; 5,03 (s, 2H, $\left.\mathrm{OCH}_{2}\right) ; 6,72(\mathrm{~s}, 1 \mathrm{H}, 4-\mathrm{H}) ; 6,78(\mathrm{dd}, 1 \mathrm{H}, J=8,6$ $\mathrm{Hz}, J=2,2 \mathrm{~Hz}, 2-\mathrm{H}) ; 7,18$ (d, 1H, $J=8,6 \mathrm{~Hz}, 1-\mathrm{H}) ; 7,33$ (t, 1H, $\left.J=7,2 \mathrm{~Hz}, 4{ }^{\prime}-\mathrm{H}\right) ; 7,38$ (t, 2H, $J=7,5 \mathrm{~Hz}, 3$ '-H és 5 '-H); 7,43 (d, $2 \mathrm{H}, J=7,5 \mathrm{~Hz}, 2$ '-H és 6 '-H). ${ }^{13} \mathrm{C}-\mathrm{NMR} \delta[\mathrm{ppm}]=15,6$ (C-18); 26,2; 27,1; 27,7; 29,7; 32,6; 36,8; 40,9 (C-13); 43,4; 44,2; 53,8 és 62,3 (2C, C-16 és 
C-17); 69,9 $\left(\mathrm{OCH}_{2}\right) ; 112,2$ (C-2); 114,8 (C-4); 126,1 (C-1); 127,4 (2C, C-2' és C-6'); 127,8 (C-4'); 128,5 (2C, C-3' és C-5'); 132,9 (C-10); 137,3 (C-1'); 137,8 (C-5); 156,7 (C-3).

\section{4}

${ }^{1} \mathrm{H}-\mathrm{NMR}\left(500 \mathrm{MHz}, \mathrm{CDCl}_{3}\right): \delta[\mathrm{ppm}]=1,11\left(\mathrm{~s}, 3 \mathrm{H}, 18-\mathrm{H}_{3}\right) ; 2,86\left(\mathrm{~m}, 2 \mathrm{H}, 6-\mathrm{H}_{2}\right), 4,07(\mathrm{~s}, 1 \mathrm{H}$, $17-\mathrm{H}) ; 4,77$ (m, 1H, 16-H); 5,04 (s, 2H, $\left.\mathrm{OCH}_{2}\right) ; 6,73(\mathrm{~s}, 1 \mathrm{H}, 4-\mathrm{H}) ; 6,79$ (d, 1H, J = 8,5 Hz, 2$\mathrm{H}) ; 7,21(\mathrm{~d}, 1 \mathrm{H}, J=8,5 \mathrm{~Hz}, 1-\mathrm{H}) ; 7,32\left(\mathrm{t}, 1 \mathrm{H}, J=7,2 \mathrm{~Hz}, 4^{\prime}-\mathrm{H}\right) ; 7,38$ (t, 2H, $J=7,4 \mathrm{~Hz}, 3^{\prime}-\mathrm{H}$ és 5 '-H); 7,43 (d, 2H, $\left.J=7,3 \mathrm{~Hz}, 2^{\prime}-\mathrm{H}, 6{ }^{\prime}-\mathrm{H}\right) .{ }^{13} \mathrm{C}-\mathrm{NMR} \delta$ [ppm] = 18,6 (C-18); 26,5; 27,9; 29,$8 ; 35,6 ; 36,9 ; 38,9 ; 43,1 ; 44,8(\mathrm{C}-13) ; 48,1 ; 70,0\left(\mathrm{OCH}_{2}\right) ; 71,7(\mathrm{C}-16) ; 82,9$ (C-17); 112,3 (C-2); 114,8 (C-4); 126,3 (C-1); 127,4 (2C, C-2' és C-6'); 127,8 (C-4'); 128,5 (2C, C-3' és C5'); 132,5 (C-10); 137,3 (C-1'); 137,8 (C-5); 156,8 (C-3).

\section{5}

${ }^{1} \mathrm{H}-\mathrm{NMR}\left(500 \mathrm{MHz}, \mathrm{CDCl}_{3}\right): \delta[\mathrm{ppm}]=0,85\left(\mathrm{~s}, 3 \mathrm{H}, 18-\mathrm{H}_{3}\right) ; 2,84\left(\mathrm{~m}, 2 \mathrm{H}, 6-\mathrm{H}_{2}\right) ; 3,26(\mathrm{~m}, 1 \mathrm{H})$ és 3,54 (m, 1H): 16-H és $17-\mathrm{H} ; 5,03\left(\mathrm{~s}, 2 \mathrm{H}, \mathrm{OCH}_{2}\right) ; 6,71(\mathrm{~d}, 1 \mathrm{H}, J=2,3 \mathrm{~Hz}, 4-\mathrm{H}) ; 6,78(\mathrm{dd}$, $1 \mathrm{H}, J=8,5 \mathrm{~Hz}, J=2,5 \mathrm{~Hz} 2-\mathrm{H}) ; 7,17$ (d, 1H, $J=8,6 \mathrm{~Hz}, 1-\mathrm{H}) ; 7,32$ (t, 1H, $\left.J=7,2 \mathrm{~Hz}, 4^{\prime}-\mathrm{H}\right)$; $7,38\left(\mathrm{t}, 2 \mathrm{H}, J=7,4 \mathrm{~Hz}, 3\right.$ '-H és 5 '-H); 7,43 (d, 2H, $J=7,2 \mathrm{~Hz}, 2$ '-H és 6 '-H). ${ }^{13} \mathrm{C}-\mathrm{NMR} \delta$ $[\mathrm{ppm}]=13,9(\mathrm{C}-18) ; 26,5 ; 27,5 ; 28,8 ; 29,6 ; 35,2 ; 37,0 ; 39,8(\mathrm{C}-13) ; 43,9 ; 59,6 ; 62,5$ és 66,6 (2C, C-16 és C-17); 70,0 $\left(\mathrm{OCH}_{2}\right) ; 112,2$ (C-2); 114,8 (C-4); 125,9 (C-1); 127,4 (2C, C-2' és C-6'); 127,8 (C-4'); 128,5 (2C, C-3' és C-5'); 132,8 (C-10); 137,3 (C-1'); 137,8 (C-5); 156,8 (C-3).

\section{6}

${ }^{1} \mathrm{H}-\mathrm{NMR}\left(500 \mathrm{MHz}, \mathrm{CDCl}_{3}\right): \delta[\mathrm{ppm}]=0,86\left(\mathrm{~s}, 3 \mathrm{H}, 18-\mathrm{H}_{3}\right) ; 2,87\left(\mathrm{~m}, 2 \mathrm{H}, 6-\mathrm{H}_{2}\right) ; 3,75(\mathrm{~s}, 1 \mathrm{H})$ és 3,83 (m, 1H): 16-H és $17-\mathrm{H} ; 5,04\left(\mathrm{~s}, 2 \mathrm{H}, \mathrm{OCH}_{2}\right) ; 6,73(\mathrm{~s}, 1 \mathrm{H}, 4-\mathrm{H}) ; 6,79(\mathrm{dd}, 1 \mathrm{H}, J=8,6$ $\mathrm{Hz}, J=2,3 \mathrm{~Hz}, 2-\mathrm{H}) ; 7,21$ (d, 1H, $J=8,6 \mathrm{~Hz}, 1-\mathrm{H}) ; 7,32$ (t, 1H, $\left.J=7,2 \mathrm{~Hz}, 4{ }^{\prime}-\mathrm{H}\right) ; 7,39$ (t, 2H, $J=7,4 \mathrm{~Hz}, 3$ '-H és 5 '-H); 7,43 (d, $2 \mathrm{H}, J=7,4 \mathrm{~Hz}, 2$ '-H és 6 '-H). ${ }^{13} \mathrm{C}-\mathrm{NMR} \delta[\mathrm{ppm}]=17,0$ (C-18); 25,7; 27,9; 29,7; 31,6; 32,3; 38,5; 43,3; 44,5 (C-13); 47,8; 69,1 (C-16); 70,0 $\left(\mathrm{OCH}_{2}\right)$; 84,7 (C-17); 112,4 (C-2); 114,8 (C-4); 126,3 (C-1); 127,4 (2C, C-2' és C-6'); 127,8 (C-4'); 128,5 (2C, C-3' és C-5'); 132,5 (C-10); 137,3 (C-1'); 137,8 (C-5); 156,8 (C-3).

\section{7}

${ }^{1} \mathrm{H}-\mathrm{NMR}\left(500 \mathrm{MHz}, \mathrm{CDCl}_{3}\right): \delta[\mathrm{ppm}]=0,83\left(\mathrm{~s}, 3 \mathrm{H}, 18-\mathrm{H}_{3}\right) ; 2,86\left(\mathrm{~m}, 2 \mathrm{H}, 6-\mathrm{H}_{2}\right) ; 3,63(\mathrm{~d}, 1 \mathrm{H}$, $J=6,6 \mathrm{~Hz})$ és 3,80 (m, 1H): 16-H és $17-\mathrm{H} ; 5,04\left(\mathrm{~s}, 2 \mathrm{H}, \mathrm{OCH}_{2}\right) ; 6,73(\mathrm{~s}, 1 \mathrm{H}, 4-\mathrm{H}) ; 6,79(\mathrm{dd}$, $1 \mathrm{H}, J=8,5 \mathrm{~Hz}, J=2,2 \mathrm{~Hz}, 2-\mathrm{H}) ; 7,19$ (d, $1 \mathrm{H}, J=8,6 \mathrm{~Hz}, 1-\mathrm{H}) ; 7,32$ (t, 1H, $J=7,2 \mathrm{~Hz}, 4^{\prime}-\mathrm{H}$ ); $7,38\left(\mathrm{t}, 2 \mathrm{H}, J=7,4 \mathrm{~Hz}, 3\right.$ '-H és 5 '-H); 7,43 (d, 2H, $J=7,2 \mathrm{~Hz}, 2$ '-H és 6'-H). ${ }^{13} \mathrm{C}-\mathrm{NMR} \delta$ $[\mathrm{ppm}]=11,9(\mathrm{C}-18) ; 25,8 ; 27,1 ; 29,6 ; 30,6,36,3 ; 38,2 ; 43,7(\mathrm{C}-13) ; 43,8 ; 48,2 ; 67,1$ (C-16); 70,0 $\left(\mathrm{OCH}_{2}\right) ; 87,3$ (C-17); 112,4 (C-2); 114,8 (C-4); 126,2 (C-1); 127,4 (2C, C-2' és C-6'); 127,8 (C-4'); 128,5 (2C, C-3' és C-5'); 132,4 (C-10); 137,2 (C-1'); 137,8 (C-5); 156,8 (C-3).

\section{9a}

${ }^{1} \mathrm{H}-\mathrm{NMR}\left(500 \mathrm{MHz}, \mathrm{CDCl}_{3}\right): \delta[\mathrm{ppm}]=1,00\left(\mathrm{~s}, 3 \mathrm{H}, 18-\mathrm{H}_{3}\right) ; 2.88\left(\mathrm{~m}, 2 \mathrm{H}, 6-\mathrm{H}_{2}\right) ; 4,17(\mathrm{~s}, 1 \mathrm{H}$, $17-\mathrm{H}) ; 4,72(\mathrm{t}, 1 \mathrm{H}, J=8,6 \mathrm{~Hz}, 16-\mathrm{H}) ; 5,05\left(\mathrm{~s}, 2 \mathrm{H}, \mathrm{OCH}_{2}\right) ; 6,74(\mathrm{~s}, 1 \mathrm{H}, 4-\mathrm{H}) ; 6,80$ (d, 1H, $J=$ 
8,4 Hz, 2-H); 7,22 (d, 1H, $J=8,5 \mathrm{~Hz}, 1-\mathrm{H}$ ); 7,32-7,35 (átfedő multiplettek, 2H, 4'-H és 4"'H); 7,37-7,44 (átfedő multiplettek, 5H, 2'-H, 3'-H, 3'- $-\mathrm{H}, 5$ '-H, 5'-H, 6'-H); 7,82-7,85 (átfedő multiplettek, 3H, C=CH, 2"-H, 6"-H). ${ }^{13} \mathrm{C}-\mathrm{NMR} \delta$ [ppm] = 17,9 (C-18); 25,8; 28,0; 29,$7 ; 31,8 ; 32,5 ; 38,3 ; 43,3 ; 44,7$ (C-13); 48,3; 70,0 ( $\left.\mathrm{OCH}_{2}\right) ; 70,1$ (C-16); 85,4 (C-17); 112,4 (C-2); 114,8 (C-4); 119,5 (C=태); 125,6 (2C) és 128,8 (2C): C-2"; C-3"; C-5"; C-6"; 126,3 (C-1); 127,4 (2C, C-2' és C-6'); 127,8 (C-4'); 128,1 (C-4”); 128,5 (2C, C-3' és C-5'); 130,5 (C-1”); 132,4 (C-10); 137,2 (C-1'); 137,8 (C-5); 156,8 (C-3).

\section{9b}

${ }^{1} \mathrm{H}-\mathrm{NMR}\left(500 \mathrm{MHz}, \mathrm{CDCl}_{3}\right): \delta[\mathrm{ppm}]=1,00\left(\mathrm{~s}, 3 \mathrm{H}, 18-\mathrm{H}_{3}\right) ; 2,88\left(\mathrm{~m}, 2 \mathrm{H}, 6-\mathrm{H}_{2}\right) ; 4,16(\mathrm{~s}, 1 \mathrm{H}$, $17-\mathrm{H}) ; 4,72$ (t, 1H, $J=8,7 \mathrm{~Hz}, 16-\mathrm{H}) ; 5,05\left(\mathrm{~s}, 2 \mathrm{H}, \mathrm{OCH}_{2}\right) ; 6,74(\mathrm{~s}, 1 \mathrm{H}, 4-\mathrm{H}) ; 6,80$ (dd, 1H, $J=$ $8,5 \mathrm{~Hz}, J=2,1 \mathrm{~Hz}, 2-\mathrm{H}) ; 7,15$ (d, 1H, $J=7,5 \mathrm{~Hz}, 4$ '”-H); 7,23 (d, 1H, $J=8,6 \mathrm{~Hz}, 1-\mathrm{H}) ; 7,29$ 7,34 (átfedő multiplettek, 2H, 4'-H és 5'-H); 7,39 (t, 2H, $J=7,4 \mathrm{~Hz}, 3$ '-H és 5'-H); 7,44 (d, $2 \mathrm{H}, J=7,3 \mathrm{~Hz}, 2$ '-H és 6'-H); 7,60 (d, 1H, $J=7,6 \mathrm{~Hz}, 6$ '-H); 7,67 (s, 1H, 2"'-H); 7,83 $(\mathrm{C}=\mathrm{CH}) .{ }^{13} \mathrm{C}-\mathrm{NMR} \delta[\mathrm{ppm}]=17,9(\mathrm{C}-18) ; 21,4\left(3{ }^{\prime}-\mathrm{CH}_{3}\right) ; 25,8 ; 28,0 ; 29,7 ; 31,8 ; 32,5 ; 38,3$; 43,3; 44,7 (C-13); 48,2; 70,0 ( $\left.\mathrm{OCH}_{2}\right) ; 70,1$ (C-16); 85,4 (C-17); 112,4 (C-2); 114,8 (C-4); $119,5(\mathrm{C}=\underline{\mathrm{CH}})$; 122,7 (C-6”); 126,3 (2C: C-1 és C-2”); 127,4 (2C, C-2' és C-6’); 127,8 (C-4'); 128,5 (2C, C-3' és C-5'); 128,7 és 128,9 (C-4" és C-5"); 130,4 (C-1"); 132,4 (C-10); 137,2

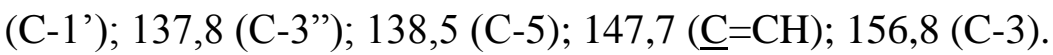

\section{9d}

${ }^{1} \mathrm{H}-\mathrm{NMR}\left(500 \mathrm{MHz}, \mathrm{CDCl}_{3}\right): \delta[\mathrm{ppm}]=1,01\left(\mathrm{~s}, 3 \mathrm{H}, 18-\mathrm{H}_{3}\right) ; 2,90\left(\mathrm{~m}, 2 \mathrm{H}, 6-\mathrm{H}_{2}\right) ; 4,18(\mathrm{~s}, 1 \mathrm{H}$, $17-\mathrm{H}) ; 4,75$ (t, 1H, $J=8,6 \mathrm{~Hz}, 16-\mathrm{H}) ; 5,05$ (s, 2H, $\left.\mathrm{OCH}_{2}\right) ; 6,74$ (d, 1H, $\left.J=2,1 \mathrm{~Hz}, 4-\mathrm{H}\right) ; 6,80$ (dd, $1 \mathrm{H}, J=8,6 \mathrm{~Hz}, J=2,4 \mathrm{~Hz}, 2-\mathrm{H}) ; 7,23(\mathrm{~d}, 1 \mathrm{H}, J=8,6 \mathrm{~Hz}, 1-\mathrm{H}) ; 7,32(\mathrm{t}, 1 \mathrm{H}, J=7,2 \mathrm{~Hz}$, 4'-H); 7,39 (t, 2H, $J=7,5 \mathrm{~Hz}, 3$ '-H és 5'-H); 7,44 (d, 2H, $J=7,3 \mathrm{~Hz}, 2$ '-H és 6'-H); 7,68 (d, $2 \mathrm{H}, J=8,1 \mathrm{~Hz}, 2$ "-H és 6"-H); 7,94-7,97 (átfedő multiplettek, 3H, C=CH, 3"-H és 5"-H). ${ }^{13} \mathrm{C}-\mathrm{NMR} \delta[\mathrm{ppm}]=17,9(\mathrm{C}-18) ; 25,8 ; 28,0 ; 29,7 ; 31,8 ; 32,5 ; 38,3 ; 43,3 ; 44,8$ (C-13); 48,3; 70,0 $\left(\mathrm{OCH}_{2}\right) ; 70,3$ (C-16); 85,4 (C-17); 112,4 (C-2); 114,9 (C-4); 120,5 (C=ㅡㅐ); 125,8 (4C, C-2"; C-3"; C-5"; C-6”); 126,3 (C-1); 127,4 (2C, C-2'; C-6'); 127,9 (C-4'); 128,5 (2C, C-3' és C-5'); 132,2 (C-10); 133,8 (C-1”); 137,2 (C-1'); 137,7 (C-5); 156,9 (C-3).

\section{9e}

${ }^{1} \mathrm{H}-\mathrm{NMR}\left(500 \mathrm{MHz}, \mathrm{CDCl}_{3}\right): \delta[\mathrm{ppm}]=0,99\left(\mathrm{~s}, 3 \mathrm{H}, 18-\mathrm{H}_{3}\right) ; 1,26\left(\mathrm{t}\left(1 \mathrm{H}, J=7,6 \mathrm{~Hz}, \mathrm{CH}_{2^{-}}\right.\right.$ $\left.\underline{\mathrm{CH}}_{3}\right) ; 2,68$ (q, $\left.2 \mathrm{H}, J=7,5 \mathrm{~Hz}, \underline{\mathrm{CH}}_{2}-\mathrm{CH}_{3}\right) ; 2,90\left(\mathrm{~m}, 2 \mathrm{H}, 6-\mathrm{H}_{2}\right) ; 4,15$ (s, 1H, 17-H); 4,70 (t, 1H, $J=8,6 \mathrm{~Hz}, 16-\mathrm{H}) ; 5,04\left(\mathrm{~s}, 2 \mathrm{H}, \mathrm{OCH}_{2}\right) ; 6,74(\mathrm{~s}, 1 \mathrm{H}, 4-\mathrm{H}) ; 6,80(\mathrm{dd}, 1 \mathrm{H}, J=8,4 \mathrm{~Hz}, J=2,0$ $\mathrm{Hz}, 2-\mathrm{H}$ ); 7,22-7,25 (átfedő multiplettek, 3H, 1-H; 3"'-H; 5'-H); 7,32 (t, 1H, J=7,0 Hz, 4'H); 7,39 (t, 2H, $J=7,4 \mathrm{~Hz}, 3$ '-H és 5'-H); 7,44 (d, 2H, $J=7,2 \mathrm{~Hz}, 2$ '-H és 6'-H); 7,74 (d, 2H, $J=8,0 \mathrm{~Hz}, 2$ "'-H és 6"-H); 7,81 (C=CH). ${ }^{13} \mathrm{C}-\mathrm{NMR} \delta[\mathrm{ppm}]=15,5\left(\mathrm{CH}_{2}-\mathrm{CH}_{3}\right) ; 17,9(\mathrm{C}-18)$; 25,$8 ; 28,0 ; 28,7 ; 29,7 ; 31,8 ; 32,5 ; 38,2 ; 43,4 ; 44,7$ (C-13); 48,3; 70,0 $\left(\mathrm{OCH}_{2}\right) ; 70,1$ (C-16); 85,3 (C-17); 112,4 (C-2); 114,8 (C-4); 119,3 (C=ㅡㅐ); 125,6 (2C) és 128,3 (2C): C-2"; C-3”; C-5"; C-6"; 126,3 (C-1); 127,4 (2C, C-2' és C-6'); 127,8 (C-4'); 127,9 (C-1"); 128,5 (2C, C3' és C-5'); 132,4 (C-10); 137,2 (C-1'); 137,8 (C-5); 144,3 és 147,6 ( $\underline{\mathrm{C}}=\mathrm{CH}$ és C-4”); 156,8 (C-3). 


\section{0a}

${ }^{1} \mathrm{H}-\mathrm{NMR}\left(500 \mathrm{MHz}, \mathrm{CDCl}_{3}\right): \delta[\mathrm{ppm}]=0,98\left(\mathrm{~s}, 3 \mathrm{H}, 18-\mathrm{H}_{3}\right) ; 2,86\left(\mathrm{~m}, 2 \mathrm{H}, 6-\mathrm{H}_{2}\right) ; 4,20(\mathrm{~d}, 1 \mathrm{H}$, $J=7,0 \mathrm{~Hz}, 17-\mathrm{H}) ; 4,73$ (t, 1H, $J=7,3 \mathrm{~Hz}, 16-\mathrm{H}) ; 5,04$ (s, 2H, $\left.\mathrm{OCH}_{2}\right) ; 6,73(\mathrm{~s}, 1 \mathrm{H}, 4-\mathrm{H}) ; 6,79$ (d, $1 \mathrm{H}, J=8,5 \mathrm{~Hz}, 2-\mathrm{H}) ; 7,20$ (d, 1H, $J=8,6 \mathrm{~Hz}, 1-\mathrm{H}) ; 7,33$ (átfedő multiplettek, 2H, 4'-H és 4"-H); 7,37-7,41 (átfedő multiplettek, 4H, 3'-H; 3"-H; 5'-H; 5"-H); 7,43 (d, 2H, J = 7,1 Hz, 2'-H és 6'-H); 7,72-7,74 (átfedő multiplettek, 3H, C=CH; 2"-H, 6"-H). ${ }^{13} \mathrm{C}-\mathrm{NMR} \delta$ [ppm] = 11,8 (C-18); 25,9; 27,1; 29,6; 31,5; 36,3; 38,3; 43,8; 44,0 (C-13); 48,6; 67,1 (C-16); 70,0 $\left(\mathrm{OCH}_{2}\right) ; 87,1(\mathrm{C}-17) ; 112,4(\mathrm{C}-2) ; 114,8(\mathrm{C}-4) ; 119,6(\mathrm{C}=\underline{\mathrm{CH}}) ; 125,6(2 \mathrm{C})$ és 128,8 (2C): C2"; C-3"; C-5"; C-6"; 126,3 (C-1); 127,4 (2C: C-2' és C-6'); 127,8 (C-4'); 128,1 (C-4”); 128,5 (2C: C-3' és C-5'); 130,3 (C-1'”); 132,4 (C-10); 137,3 (C-1'); 137,8 (C-5); 156,8 (C-3).

\section{0b}

${ }^{1} \mathrm{H}-\mathrm{NMR}\left(500 \mathrm{MHz}, \mathrm{CDCl}_{3}\right): \delta[\mathrm{ppm}]=0,98\left(\mathrm{~s}, 3 \mathrm{H}, 18-\mathrm{H}_{3}\right) ; 2,39\left(\mathrm{~s}, 3 \mathrm{H}, 3\right.$ "'- $\left.\mathrm{CH}_{3}\right) ; 2,87$ (m, $\left.2 \mathrm{H}, 6-\mathrm{H}_{2}\right) ; 4,18(\mathrm{~d}, 1 \mathrm{H}, J=7,0 \mathrm{~Hz}, 17-\mathrm{H}) ; 4,73(\mathrm{~m}, 1 \mathrm{H}, 16-\mathrm{H}) ; 5,04$ (s, 2H, OCH$) ; 6,73$ (s, $1 \mathrm{H}, 4-\mathrm{H}) ; 6,79$ (dd, $1 \mathrm{H}, J=8,5 \mathrm{~Hz}, J=2,0 \mathrm{~Hz}, 2-\mathrm{H}) ; 7,14$ (d, 1H, $J=7,4 \mathrm{~Hz}, 4$ "'-H); 7,21 (d, $1 \mathrm{H}, J=8,6 \mathrm{~Hz}, 1-\mathrm{H}$ ); 7,28-7,34 (átfedő multiplettek, $2 \mathrm{H}, 4$ '-H és 5"-H); 7,39 (t, 2H, $J=7,4$ $\mathrm{Hz}, 3$ '-H és 5'-H); 7,44 (d, 2H, $J=7,2 \mathrm{~Hz}, 2$ '-H és 6'-H); 7,53-7,56 (átfedő multiplettek, $2 \mathrm{H}$, 2"-H és 6"-H); 7,71 (C=CH). ${ }^{13} \mathrm{C}-\mathrm{NMR} \delta[\mathrm{ppm}]=11,8(\mathrm{C}-18) ; 21,4\left(3\right.$ "- $\left.\mathrm{CH}_{3}\right) ; 25,9 ; 27,1$; 29,$6 ; 31,5 ; 36,3 ; 38,3 ; 43,8 ; 43,9$ (C-13); 48,6; 67,0 (C-16); 70,0 $\left(\mathrm{OCH}_{2}\right) ; 87,1(\mathrm{C}-17) ; 112,4$ (C-2); 114,8 (C-4); 119,4 (C=ㅡH); 122,7 (C-6”); 126,3 (2C, C-1 és C-2”); 127,4 (2C, C-2' és C-6'); 127,8 (C-4'); 128,5 (C-3' és C-5'); 128,7 és 128,9 (2C, C-4” és C-5”); 130,3 (C-1”); 132,4 (C-10); 137,2 (C-1'); 137,8 (C-3”); 138,4 (C-5); 147,5 (C-5); 156,8 (C-3).

\section{0c}

${ }^{1} \mathrm{H}-\mathrm{NMR}\left(500 \mathrm{MHz}, \mathrm{CDCl}_{3}\right): \delta[\mathrm{ppm}]=0,97\left(\mathrm{~s}, 3 \mathrm{H}, 18-\mathrm{H}_{3}\right) ; 2,38\left(\mathrm{~s}, 3 \mathrm{H}, 4\right.$ "'- $\left.\mathrm{CH}_{3}\right) ; 2,86(\mathrm{~m}$, $\left.2 \mathrm{H}, 6-\mathrm{H}_{2}\right) ; 4,18(\mathrm{~d}, 1 \mathrm{H}, J=6,8 \mathrm{~Hz}, 17-\mathrm{H}) ; 4,71(\mathrm{~m}, 1 \mathrm{H}, 16-\mathrm{H}) ; 5,04\left(\mathrm{~s}, 2 \mathrm{H}, \mathrm{OCH}_{2}\right) ; 6,73$ (s, $1 \mathrm{H}, 4-\mathrm{H}) ; 6,79$ (d, 1H, $J=8,3 \mathrm{~Hz}, 2-\mathrm{H}) ; 7,20-7,21$ (átfedő multiplettek, 3H, 1-H; 3"-H, 5"H); 7,32 (m, 1H, 4'-H); 7,38 (t, 2H, $J=7,3 \mathrm{~Hz}, 3$ '-H és 5'-H); 7,43 (d, 2H, $J=7,3 \mathrm{~Hz}, 2^{\prime}$-H és 6'-H); 7,63 (d, 2H, $J=7,7 \mathrm{~Hz}, 2$ "-H és 6 "'-H); 7,68 (s, 1H, C=CH). ${ }^{13} \mathrm{C}-\mathrm{NMR} \delta$ [ppm] = 11,8 (C-18); 21,3 (4"'-CH$) ; 25,9 ; 27,1 ; 29,6 ; 31,5 ; 36,3 ; 38,3 ; 43,8 ; 43,9$ (C-13); 48,6; 67,0 (C-16); 70,0 $\left(\mathrm{OCH}_{2}\right) ; 87,1(\mathrm{C}-17) ; 112,4(\mathrm{C}-2) ; 114,8(\mathrm{C}-4) ; 119,2(\mathrm{C}=\underline{\mathrm{CH}}) ; 125,5$ (2C) és 129,5 (2C): C-2"; C-3"; C-5"; C-6"; 126,3 (C-1); 127,4 (2C, C-2' és C-6'); 127,6 (C-1"); 127,8 (C-4'); 128,5 (2C, C-3' és C-5'); 132,4 (C-10); 137,3 és 137,8 és 137,9 (C-1'; C-5; C$\left.4^{\prime}\right) ; 147,4(\underline{\mathrm{C}}=\mathrm{CH}) ; 156,8(\mathrm{C}-3)$.

\section{0d}

${ }^{1} \mathrm{H}-\mathrm{NMR}\left(500 \mathrm{MHz}, \mathrm{CDCl}_{3}\right): \delta[\mathrm{ppm}]=0,98\left(\mathrm{~s}, 3 \mathrm{H}, 18-\mathrm{H}_{3}\right) ; 2,87\left(\mathrm{~m}, 2 \mathrm{H}, 6-\mathrm{H}_{2}\right) ; 4,20(\mathrm{~d}, 1 \mathrm{H}$, $J=7,2 \mathrm{~Hz}, 17-\mathrm{H}) ; 4,75(\mathrm{~m}, 1 \mathrm{H}, 16-\mathrm{H}) ; 5,04$ (s, 2H, $\left.\mathrm{OCH}_{2}\right) ; 6,74$ (s, 1H, 4-H); 6,79 (dd, 1H J $=8,5 \mathrm{~Hz}, J=2,4 \mathrm{~Hz}, 2-\mathrm{H}) ; 7,20$ (d, 1H, $J=8,6 \mathrm{~Hz}, 1-\mathrm{H}) ; 7,33$ (t, $1 \mathrm{H}, J=7,2 \mathrm{~Hz}, 4$ '-H); 7,38 (t, 2H, $\left.J=7,2 \mathrm{~Hz}, 3^{\prime}-\mathrm{H}_{\text {és }} 5^{\prime}-\mathrm{H}\right)$; 7,43 (d, 2H, $J=7,3 \mathrm{~Hz}, 2^{\prime}-\mathrm{H}$ és 6'-H); 7,64 (d, 2H, $J=8,2$ 
$\mathrm{Hz}, 2$ "-H és 6"-H); 7,86 (átfedő multiplettek, 3H, C=CH, 3H, 3"-H és 5"-H). ${ }^{13} \mathrm{C}-\mathrm{NMR} \delta$ $[\mathrm{ppm}]=11,8(\mathrm{C}-18) ; 25,9 ; 27,1 ; 29,6 ; 31,4 ; 36,3 ; 38,3 ; 43,8 ; 44,0$ (C-13); 48,7; 67,1 (C-16); 70,0 $\left(\mathrm{OCH}_{2}\right) ; 87,2(\mathrm{C}-17) ; 112,4(\mathrm{C}-2) ; 114,9(\mathrm{C}-4) ; 120,5(\mathrm{C}=\underline{\mathrm{CH}}) ; 125,6(2 \mathrm{C})$ és 125,8 (2C): C-2"; C-3"; C-5"; C-6"; 126,3 (C-1); 127,4 (2C, C-2' és C-6'); 127,9 (C-4'); 128,5 (2C, C-3' és C-5'); 132,3 (C-10); 133,9 (C-1"); 137,3 (C-1'); 137,7 (C-5); 146,0 ( $\underline{C}=\mathrm{CH}) ; 156,9$ (C-3).

\section{0e}

${ }^{1} \mathrm{H}-\mathrm{NMR}\left(500 \mathrm{MHz}, \mathrm{CDCl}_{3}\right): \delta[\mathrm{ppm}]=0,97\left(\mathrm{~s}, 3 \mathrm{H}, 18-\mathrm{H}_{3}\right) ; 1,27\left(\mathrm{~d}, 3 \mathrm{H}, J=7,6 \mathrm{~Hz}, \mathrm{CH}_{2}-\right.$ $\left.\underline{\mathrm{CH}}_{3}\right) ; 2,68\left(\mathrm{q}, 2 \mathrm{H}, J=7,6 \mathrm{~Hz}, \underline{\mathrm{CH}}_{2}-\mathrm{CH}_{3}\right) ; 2,86\left(\mathrm{~m}, 2 \mathrm{H}, 6-\mathrm{H}_{2}\right) ; 4,19(\mathrm{~m}, 1 \mathrm{H}, 17-\mathrm{H}) ; 4,71$ (m, $1 \mathrm{H}, 16-\mathrm{H}) ; 5,04$ (s, 2H, $\left.\mathrm{OCH}_{2}\right) ; 6,73(\mathrm{~s}, 1 \mathrm{H}, 4-\mathrm{H}) ; 6,79$ (dd, 1H, J=8,5 Hz, J=2,4 Hz, 2-H); 7,20-7,26 (átfedő multiplettek, 3H, 1-H; 3"-H; 5"-H); 7,33 (t, 1H, J = 7,3 Hz, 4'-H); 7,39 (t, $2 \mathrm{H}, J=7,5 \mathrm{~Hz}, 3^{\prime}$-H és 5'-H); 7,44 (d, 2H, $J=7,3 \mathrm{~Hz}, 2^{\prime}-\mathrm{H}$ és 6'-H); 7,64 (d, 2H, $J=8,0 \mathrm{~Hz}$, 2"-H és 6 "-H); 7,68 (s, $1 \mathrm{H}, \mathrm{C}=\mathrm{CH}) .{ }^{13} \mathrm{C}-\mathrm{NMR} \delta[\mathrm{ppm}]=11,8(\mathrm{C}-18) ; 15,5\left(\mathrm{CH}_{2}-\mathrm{CH}_{3}\right) ; 25,9$; 27,$1 ; 28,7 ; 29,7 ; 31,5 ; 36,3 ; 38,3 ; 43,8 ; 43,9$ (C-13); 48,6; 67,0 (C-16); 70,0 $\left(\mathrm{OCH}_{2}\right) ; 87,1$ (C17); 112,4 (C-2); 114,8 (C-4); 119,3 (C=다); 125,6 (2C) és 128,2 (2C): C-2"; C-3"; C-5"; C6"; 126,3 (C-1); 127,4 (2C, C-2' és C-6'); 127,8 (C-4'); 128,5 (2C, C-3' és C-5'); 128,8 (C1”); 132,4 (C-10); 137,2 (C-1'); 137,8 (C-5); 144,3 és 147,4 (2C, C-4" és $\underline{C=C H) ; ~ 156,8 ~(C-~}$ $3)$.

\section{1}

${ }^{1} \mathrm{H}-\mathrm{NMR}\left(500 \mathrm{MHz}, \mathrm{CDCl}_{3}\right): \delta[\mathrm{ppm}]=0,98\left(\mathrm{~s}, 3 \mathrm{H}, 18-\mathrm{H}_{3}\right) ; 2,90\left(\mathrm{~m}, 2 \mathrm{H}, 6-\mathrm{H}_{2}\right) ; 3,79(\mathrm{~m}, 1 \mathrm{H}$, $16-\mathrm{H}) ; 5,04$ (s, 2H, $\left.\mathrm{OCH}_{2}\right) ; 6,74(\mathrm{~s}, 1 \mathrm{H}, 4-\mathrm{H}) ; 6,79$ (d, 1H, $\left.J=2,2 \mathrm{~Hz}, 2-\mathrm{H}\right) ; 7,19$ (d, 1H, $J=$ $8,6 \mathrm{~Hz}, 1-\mathrm{H}) ; 7,32$ (t, 1H, $\left.J=7,0 \mathrm{~Hz}, 4^{\prime}-\mathrm{H}\right) ; 7,38$ (t, 2H, $J=7,4 \mathrm{~Hz}, 3^{\prime}-\mathrm{H}$ és 5'-H); 7,43 (d, $2 \mathrm{H}, J=7,3 \mathrm{~Hz}, 2$ '-H és 6 '-H). ${ }^{13} \mathrm{C}-\mathrm{NMR} \delta$ [ppm] = 14,2 (C-18); 25,6; 26,6; 28,7; 29,5; 31,7; 37,$6 ; 44,0 ; 45,9 ; 47,4(\mathrm{C}-13) ; 63,2(\mathrm{C}-16) ; 70,0\left(\mathrm{OCH}_{2}\right) ; 112,5(\mathrm{C}-2) ; 114,9(\mathrm{C}-4) ; 126,2$ (C1); 127,4 (2C, C-2' és C-6'); 127,9 (C-4'); 128,5 (2C, C-3' és C-5'); 131,8 (C-10); 137,2 (C1'); 137,6 (C-5); 157,0 (C-3); 215,0 (C=O).

172

${ }^{1} \mathrm{H}-\mathrm{NMR}\left(500 \mathrm{MHz}, \mathrm{CDCl}_{3}\right): \delta[\mathrm{ppm}]=0,80\left(\mathrm{~s}, 3 \mathrm{H}, 18-\mathrm{H}_{3}\right) ; 2,87\left(\mathrm{~m}, 2 \mathrm{H}, 6-\mathrm{H}_{2}\right) ; 3,64(\mathrm{~d}, 1 \mathrm{H}$, $J=8,1 \mathrm{~Hz}, 17-\mathrm{H}) ; 4,14(\mathrm{~m}, 1 \mathrm{H}, 16-\mathrm{H}) ; 5,04\left(\mathrm{~s}, 2 \mathrm{H}, \mathrm{OCH}_{2}\right) ; 6,73(\mathrm{~d}, 1 \mathrm{H}, J=2,3 \mathrm{~Hz}, 4-\mathrm{H})$; $6,79$ (dd, 1H, $J=8,6 \mathrm{~Hz}, J=2,5 \mathrm{~Hz}, 2-\mathrm{H}) ; 7,20(\mathrm{~d}, 1 \mathrm{H}, J=8,6 \mathrm{~Hz}, 1-\mathrm{H}) ; 7,32(\mathrm{t}, 1 \mathrm{H}, J=7,2$ $\mathrm{Hz}, 4$ '-H); 7,39 (t, 2H, $J=7,5 \mathrm{~Hz}, 3$ '-H és 5'-H); 7,44 (d, 2H, $J=7,3 \mathrm{~Hz}, 2$ '-H és 6'-H). ${ }^{13} \mathrm{C}$ NMR $\delta[\mathrm{ppm}]=11,4(\mathrm{C}-18) ; 25,9,27,3 ; 29,6 ; 32,1 ; 37,0 ; 38,1 ; 43,0$ (C-13); 44,0; 47,1; 62,1 $(\mathrm{C}-16) ; 69,9\left(\mathrm{OCH}_{2}\right) ; 81,4(\mathrm{C}-17) ; 112,4(\mathrm{C}-2) ; 114,8(\mathrm{C}-4) ; 126,3$ (C-1); 127,4 (2C, C-2' és C-6'); 127,8 (C-4'); 128,5 (2C, C-3' és C-5'); 132,5 (C-10); 137,3 (C-1'); 137,7 (C-5); 156,8 (C-3).

173

${ }^{1} \mathrm{H}-\mathrm{NMR}\left(500 \mathrm{MHz}, \mathrm{CDCl}_{3}\right): \delta[\mathrm{ppm}]=0,74\left(\mathrm{~s}, 3 \mathrm{H}, 18-\mathrm{H}_{3}\right) ; 2,83\left(\mathrm{~m}, 2 \mathrm{H}, 6-\mathrm{H}_{2}\right) ; 4,50(\mathrm{~s}, 1 \mathrm{H}$, 3-OH); 6,56 (d, 1H, $J=2,2 \mathrm{~Hz}, 4-\mathrm{H}) ; 6,62(\mathrm{dd}, 1 \mathrm{H}, J=8,4 \mathrm{~Hz}, J=2,5 \mathrm{~Hz}, 2-\mathrm{H}) ; 7,17$ (d, 1H, 
$J=8,4 \mathrm{~Hz}, 1-\mathrm{H}) .{ }^{13} \mathrm{C}-\mathrm{NMR} \delta[\mathrm{ppm}]=17,6(\mathrm{C}-18) ; 20,6 ; 25,2 ; 26,8 ; 28,1 ; 29,8 ; 38,8 ; 39,1$; 40,5; 41,1 (C-13); 44,0; 53,5; 112,5 (C-2); 115,2 (C-4); 126,5 (C-1); 133,2 (C-10); 138,4 (C$5) ; 153,1(\mathrm{C}-3)$.

\section{Melléklet}

A vegyületek NMR- és MS-adatai

177a

${ }^{1} \mathrm{H}-\mathrm{NMR}(500 \mathrm{MHz}, \mathrm{DMSO}): \delta[\mathrm{ppm}]=0,90\left(\mathrm{~s}, 3 \mathrm{H}, 18-\mathrm{H}_{3}\right) ; 1,76\left(\mathrm{~s}, 3 \mathrm{H}, \mathrm{Ac}-\mathrm{CH}_{3}\right) ; 2,72(\mathrm{~m}$, $\left.2 \mathrm{H}, 6-\mathrm{H}_{2}\right) ; 3,69\left(\mathrm{~m}, 4 \mathrm{H}, 3-\mathrm{OCH}_{3}\right.$ és $\left.16-\mathrm{H}\right) ; 3,77(\mathrm{~m}, 1 \mathrm{H}, 17 \mathrm{a}-\mathrm{H}) ; 4,40(\mathrm{~d}, 1 \mathrm{H}, J=5,0 \mathrm{~Hz}$, $\mathrm{OH}) ; 6,61(\mathrm{~d}, 1 \mathrm{H}, J=2,2 \mathrm{~Hz}, 4-\mathrm{H}) ; 6,67(\mathrm{dd}, 1 \mathrm{H}, J=8,6 \mathrm{~Hz}, J=2,2 \mathrm{~Hz}, 2-\mathrm{H}) ; 7,17(\mathrm{~d}, 1 \mathrm{H}, J$ $=8,6 \mathrm{~Hz}, 1-\mathrm{H}) ; 7,70(\mathrm{~d}, 1 \mathrm{H}, J=7,5 \mathrm{~Hz}, \mathrm{NH}) .{ }^{13} \mathrm{C}-\mathrm{NMR} \delta[\mathrm{ppm}]=22,0$ és 22,7 (2C: C-18 és Ac- $\left.\underline{C H}_{3}\right) ; 25,9 ; 26,1 ; 28,2 ; 29,5 ; 34,8 ; 36,9 ; 37,1$ (C-13); 37,2; 42,3; 42,6; 47,2; 54,8 (3$\left.\mathrm{OCH}_{3}\right) ; 65,0$ (C-17a); 111,5 (C-2); 112,9 (C-4); 126,1 (C-1); 132,4 (C-10); 137,4 (C-5); 156,9 (C-3); 167,9 (NCO). MS m/z (\%): 340 (37); 358 (100, [M+H $\left.\left.\mathrm{H}_{2} \mathrm{O}\right]\right) ; 380$ (20).

\section{7b}

${ }^{1} \mathrm{H}-\mathrm{NMR}(500 \mathrm{MHz}, \mathrm{DMSO}): \delta[\mathrm{ppm}]=1,17\left(\mathrm{~s}, 3 \mathrm{H}, 18-\mathrm{H}_{3}\right) ; 1,81\left(\mathrm{~s}, 3 \mathrm{H}, \mathrm{Ac}-\mathrm{CH}_{3}\right) ; 2,72(\mathrm{~m}$, $\left.2 \mathrm{H}, 6-\mathrm{H}_{2}\right) ; 3,67\left(\mathrm{~m}, 4 \mathrm{H}, 3-\mathrm{OCH}_{3}\right.$ és $\left.16-\mathrm{H}\right) ; 3,76(\mathrm{~m}, 1 \mathrm{H}, 17 \mathrm{a}-\mathrm{H}) ; 6,56(\mathrm{~d}, 1 \mathrm{H}, J=2,2 \mathrm{~Hz}, 4-$ $\mathrm{H}) ; 6,67(\mathrm{dd}, 1 \mathrm{H}, J=8,6 \mathrm{~Hz}, J=2,2 \mathrm{~Hz}, 2-\mathrm{H}) ; 7,06(\mathrm{~d}, 1 \mathrm{H}, J=8,6 \mathrm{~Hz}, 1-\mathrm{H}) .{ }^{13} \mathrm{C}-\mathrm{NMR} \delta$ $[\mathrm{ppm}]=20,8\left(\mathrm{Ac}-\mathrm{CH}_{3}\right) ; 24,8 ; 25,9 ; 26,0 ; 27,4(\mathrm{C}-18) ; 29,8 ; 30,0 ; 34,7 ; 38,3 ; 38,6(\mathrm{C}-13)$; 38,$8 ; 44,1 ; 44,8 ; 54,8\left(3-\mathrm{OCH}_{3}\right) ; 79,4$ (C-17a); 111,8 (C-2); 112,8 (C-4); 127,0 (C-1); 134,2 (C-10); 136,8 (C-5); 156,0 (NCO); 156,8 (C-3). MS m/z (\%): 340 (100); $341\left(20[\mathrm{M}+\mathrm{H}]^{+}\right)$.

\section{$178 \mathbf{a}$}

${ }^{1} \mathrm{H}-\mathrm{NMR}(500 \mathrm{MHz}, \mathrm{DMSO}): \delta$ [ppm] = 0,91 (s, 3H, 18- $\left.\mathrm{H}_{3}\right) ; 2,75\left(\mathrm{~m}, 2 \mathrm{H}, 6-\mathrm{H}_{2}\right) ; 3,69$ (s, 3H, $\left.3-\mathrm{OCH}_{3}\right) ; 3,70(\mathrm{~m}, 1 \mathrm{H}, 16-\mathrm{H}) ; 3,80(\mathrm{~m}, 1 \mathrm{H}, 17 \mathrm{a}-\mathrm{H}) ; 4,00\left(\mathrm{~s}, 2 \mathrm{H}, \mathrm{CH}_{2} \mathrm{Cl}\right) ; 4,44(\mathrm{~d}, 1 \mathrm{H}, J=5,0$ $\mathrm{Hz}, \mathrm{OH}) ; 6,62(\mathrm{~d}, 1 \mathrm{H}, J=2,2 \mathrm{~Hz}, 4-\mathrm{H}) ; 6,68(\mathrm{dd}, 1 \mathrm{H}, J=8,6 \mathrm{~Hz}, J=2,2 \mathrm{~Hz}, 2-\mathrm{H}) ; 7,18$ (d, $1 \mathrm{H}, J=8,6 \mathrm{~Hz}, 1-\mathrm{H}) ; 8,10(\mathrm{~d}, 1 \mathrm{H}, J=7,5 \mathrm{~Hz}, \mathrm{NH}) .{ }^{13} \mathrm{C}-\mathrm{NMR} \delta$ [ppm] = 22,0 (C-18); 25,9; 26,$1 ; 27,8 ; 29,5 ; 34,8 ; 36,6 ; 36,9 ; 37,2 ; 42,6 ; 42,7\left(\mathrm{CH}_{2} \mathrm{Cl}\right) ; 43,4 ; 47,2 ; 54,8\left(3-\mathrm{OCH}_{3}\right) ; 64,9$ (C-17a); 111,5 (C-2); 112,9 (C-4); 126,1 (C-1); 132,4 (C-10); 137,3 (C-5); 156,9 (C-3); 164,7 (NCO). MS m/z (\%): $374\left(100,[\mathrm{M}+\mathrm{H}]^{+}\right) ; 59(23) ; 376(33)$.

\section{$178 b$}

${ }^{1} \mathrm{H}-\mathrm{NMR}(500 \mathrm{MHz}, \mathrm{DMSO}): \delta$ [ppm] = 1,23 (s, 3H, 18- $\left.\mathrm{H}_{3}\right) ; 2,72\left(\mathrm{~m}, 2 \mathrm{H}, 6-\mathrm{H}_{2}\right) ; 3,50(\mathrm{~s}, 1 \mathrm{H}$, $16-\mathrm{H}) ; 3,68\left(\mathrm{~s}, 3 \mathrm{H}, 3-\mathrm{OCH}_{3}\right) ; 3,92(\mathrm{~s}, 1 \mathrm{H}, 17 \mathrm{a}-\mathrm{H}) ; 4,02$ és 4,14 (2xd, 2x1H, $J=11,8 \mathrm{~Hz}$, $\left.\mathrm{CH}_{2} \mathrm{Cl}\right) ; 6,56(\mathrm{~d}, 1 \mathrm{H}, J=2,2 \mathrm{~Hz}, 4-\mathrm{H}) ; 6,68(\mathrm{dd}, 1 \mathrm{H}, J=8,6 \mathrm{~Hz}, J=2,2 \mathrm{~Hz}, 2-\mathrm{H}) ; 7,06(\mathrm{~d}$, $1 \mathrm{H}, J=8,6 \mathrm{~Hz}, 1-\mathrm{H}) .{ }^{13} \mathrm{C}-\mathrm{NMR} \delta[\mathrm{ppm}]=24,5 ; 25,8 ; 25,9 ; 26,9$ (C-18); 29,8; 30,0; 34,7; 38,$0 ; 38,3 ; 38,8 ; 43,7\left(\mathrm{CH}_{2} \mathrm{Cl}\right) ; 44,0 ; 45,3 ; 54,7\left(3-\mathrm{OCH}_{3}\right) ; 80,2(\mathrm{C}-17 \mathrm{a}) ; 111,8(\mathrm{C}-2) ; 112,8$ 
(C-4); 126,9 (C-1); 134,2 (C-10); 136,7 (C-5); 154,9 (NCO); 156,7 (C-3). MS m/z (\%): 374 $\left(100,[\mathrm{M}+\mathrm{H}]^{+}\right) ; 376(33)$.

\section{$178 \mathrm{c}$}

${ }^{1} \mathrm{H}-\mathrm{NMR}(500 \mathrm{MHz}, \mathrm{DMSO}): \delta[\mathrm{ppm}]=0,88$ (s, 3H, 18- $\left.\mathrm{H}_{3}\right) ; 2,67$ (m, 2H, 6- $\left.\mathrm{H}_{2}\right) ; 3,69$ (s, 3H, $\left.3-\mathrm{OCH}_{3}\right) ; 3,92(\mathrm{~m}, 1 \mathrm{H}, 16-\mathrm{H}) ; 3,93(\mathrm{~d}, 1 \mathrm{H}, J=11,8 \mathrm{~Hz})$ és 4,02 (d, $\left.1 \mathrm{H}, J=11,8 \mathrm{~Hz}\right): \mathrm{CH}_{2} \mathrm{Cl}$; $4,07(\mathrm{~m}, 1 \mathrm{H}, 17 \mathrm{a}-\mathrm{H}) ; 4,31(\mathrm{~d}, 1 \mathrm{H}, J=5,0 \mathrm{~Hz}, \mathrm{OH}) ; 6,59$ (d, 1H, $J=2,2 \mathrm{~Hz}, 4-\mathrm{H}) ; 6,68$ (dd, $1 \mathrm{H}, J=8,6 \mathrm{~Hz}, J=2,2 \mathrm{~Hz}, 2-\mathrm{H}) ; 7,20(\mathrm{~d}, 1 \mathrm{H}, J=8,6 \mathrm{~Hz}, 1-\mathrm{H}) ; 8,15(\mathrm{~d}, 1 \mathrm{H}, J=7,5 \mathrm{~Hz}, \mathrm{NH})$. ${ }^{13} \mathrm{C}-\mathrm{NMR} \delta[\mathrm{ppm}]=21,5(\mathrm{C}-18) ; 23,6 ; 26,2 ; 26,4 ; 29,6 ; 33,8 ; 35,3 ; 37,5 ; 38,5 ; 42,5\left(\mathrm{CH}_{2} \mathrm{Cl}\right)$; 43,4; 46,1; 47,3; 54,8 (3-OCH $) ; 62,4$ (C-17a); 111,6 (C-2); 112,7 (C-4); 126,4 (C-1); 132,2 (C-10); 137,5 (C-5); 156,9 (C-3); 164,9 (NCO). MS m/z (\%): 374 (100, [M+H] $\left.]^{+}\right) ; 337$ (20); $376(33)$.

\section{9a}

${ }^{1} \mathrm{H}-\mathrm{NMR}(500 \mathrm{MHz}, \mathrm{DMSO}): \delta[\mathrm{ppm}]=0,95$ (s, 3H, 18- $\left.\mathrm{H}_{3}\right) ; 2,77\left(\mathrm{~m}, 2 \mathrm{H}, 6-\mathrm{H}_{2}\right) ; 3,70$ (s, 3H, $\left.3-\mathrm{OCH}_{3}\right) ; 3,85(\mathrm{~m}, 1 \mathrm{H}, 17 \mathrm{a}-\mathrm{H}) ; 3,99(\mathrm{~m}, 1 \mathrm{H}, 16-\mathrm{H}) ; 4,45(\mathrm{~d}, 1 \mathrm{H}, J=5,0 \mathrm{~Hz}, \mathrm{OH}) ; 6,63(\mathrm{~d}$, $1 \mathrm{H}, J=2,2 \mathrm{~Hz}, 4-\mathrm{H}) ; 6,68$ (dd, $1 \mathrm{H}, J=8,6 \mathrm{~Hz}, J=2,2 \mathrm{~Hz}, 2-\mathrm{H}) ; 7,19$ (d, 1H, $J=8,6 \mathrm{~Hz}, 1-$ $\mathrm{H}) ; 7,45$ (t, 2H, $J=7,1 \mathrm{~Hz}, 3$ '-H és 5'-H); 7,50 (t, 1H, $\left.J=7,1 \mathrm{~Hz}, 4^{\prime}-\mathrm{H}\right) ; 7,85$ (d, 2H, $J=7,1$ $\mathrm{Hz}, 2$ '-H és 6'-H); 8,23 (d, 1H, $J=7,5 \mathrm{~Hz}, \mathrm{NH}) .{ }^{13} \mathrm{C}-\mathrm{NMR} \delta$ [ppm] = 22,1 (C-18); 26,0; 26,2; 27,$9 ; 29,6 ; 34,8 ; 36,7 ; 37,0 ; 37,3 ; 42,7 ; 43,1 ; 47,4 ; 54,8\left(3-\mathrm{OCH}_{3}\right) ; 65,1(\mathrm{C}-17 \mathrm{a}) ; 111,5$ (C-2); 112,9 (C-4); 126,2 (C-1); 127,1 (2C: C-2' és C-6'); 128,1 (2C: C-3' és C-5'); 130,9 (C-4'); 132,5 (C-10); 134,7 (C-1'); 137,4 (C-5); 157,0 (C-3); 165,2 (NCO). MS m/z (\%):402 (67, $\left.[\mathrm{M}+\mathrm{H}]^{+}\right) ; 420(100) ; 442(43)$.

\section{9b}

${ }^{1} \mathrm{H}-\mathrm{NMR}$ (500 MHz, DMSO): $\delta$ [ppm] = 1,26 (s, 3H, 18- $\left.\mathrm{H}_{3}\right) ; 2,70$ (m, 2H, 6- $\mathrm{H}_{2}$ ); 3,68 (átfedő multiplettek, 4H, 3-OCH $\mathrm{OC}_{3}$ 16-H); 4,06 (m, 1H, 17a-H); 6,55 (d, 1H, $\left.J=2,2 \mathrm{~Hz}, 4-\mathrm{H}\right) ; 6,68$ (dd, $1 \mathrm{H}, J=8,6 \mathrm{~Hz}, J=2,2 \mathrm{~Hz}, 2-\mathrm{H}) ; 7,07$ (d, $1 \mathrm{H}, J=8,6 \mathrm{~Hz}, 1-\mathrm{H}) ; 7,41$ (t, 2H, $J=7,1 \mathrm{~Hz}$, 3'-H és 5'-H); 7,44 (t, $1 \mathrm{H}, J=7,1 \mathrm{~Hz}, 4$ '-H); 7,88 (d, $2 \mathrm{H}, J=7,1 \mathrm{~Hz}, 2$ '-H és 6 '-H). ${ }^{13} \mathrm{C}$ NMR $\delta$ [ppm] $=25,0 ; 25,9 ; 26,0 ; 27,3(\mathrm{C}-18) ; 29,6 ; 30,0 ; 34,6 ; 38,5 ; 39,0$ (2C); 44,0; 45,4; 54,7 (3-OCH $\left.{ }_{3}\right) ; 80,0(\mathrm{C}-17 \mathrm{a}) ; 111,8(\mathrm{C}-2) ; 112,8$ (C-4); 126,5 (2C: C-2' és C-6'); 127,0 (C1); 128,1 (2C: C-3' és C-5'); 130,2 (C-4'); 133,4 és 134,1 (C-10 és C-1'); 136,7 (C-5); 153,9 (NCO); 156,7 (C-3). MS m/z (\%):402 (100, $\left.[\mathrm{M}+\mathrm{H}]^{+}\right) ; 403(30)$.

\section{0a}

${ }^{1} \mathrm{H}-\mathrm{NMR}(500 \mathrm{MHz}, \mathrm{DMSO}): \delta[\mathrm{ppm}]=0,90\left(\mathrm{~s}, 3 \mathrm{H}, 18-\mathrm{H}_{3}\right) ; 1,76\left(\mathrm{~s}, 3 \mathrm{H}, \mathrm{Ac}_{-} \mathrm{CH}_{3}\right) ; 2,72(\mathrm{~m}$, $\left.2 \mathrm{H}, 6-\mathrm{H}_{2}\right) ; 3,69(\mathrm{~m}, 1 \mathrm{H}, 16-\mathrm{H}) ; 3,78(\mathrm{~m}, 1 \mathrm{H}, 17 \mathrm{a}-\mathrm{H}) ; 4,40(\mathrm{~d}, 1 \mathrm{H}, J=5,0 \mathrm{~Hz}, \mathrm{OH}) ; 5,04$ (s, $\left.2 \mathrm{H}, \mathrm{OCH}_{2}\right) ; 6,71(\mathrm{~d}, 1 \mathrm{H}, J=2,2 \mathrm{~Hz}, 4-\mathrm{H}) ; 6,75(\mathrm{dd}, 1 \mathrm{H}, J=8,6 \mathrm{~Hz}, J=2,2 \mathrm{~Hz}, 2-\mathrm{H}) ; 7,18$ (d, $1 \mathrm{H}, J=8,6 \mathrm{~Hz}, 1-\mathrm{H})$; 7,32 (t, 1H, $J=7,1 \mathrm{~Hz}, 4$ '-H); 7,38 (t, 2H, $J=7,1 \mathrm{~Hz}, 3$ '-H és 5'-H); $7,42\left(\mathrm{~d}, 2 \mathrm{H}, J=7,1 \mathrm{~Hz}, 2\right.$ '-H és 6 '-H); $7,71(\mathrm{~d}, 1 \mathrm{H}, J=7,5 \mathrm{~Hz}, \mathrm{NH}) .{ }^{13} \mathrm{C}-\mathrm{NMR} \delta[\mathrm{ppm}]=$ 22,0 (C-18); 22,7 (Ac- CH$\left._{3}\right) ; 25,9 ; 26,1 ; 28,2 ; 29,5 ; 34,8 ; 36,9 ; 37,1 ; 37,2 ; 42,3$ (C-16); 42,7; 
47,2; 64,9 (C-17a); 68,9 (OCH $)$; 112,3 (C-2); 114,0 (C-4); 126,2 (C-1); 127,4 (2C: C-2' és C-6'); 127,6 (C-4'); 128,3 (2C: C-3' és C-5'); 132,7 (C-10); 137,3 (C-1'); 137,4 (C-5); 156,0 (C-3); 167,9 (NCO). MS m/z (\%): 416 (100, [M+H] $\left.]^{+}\right) ; 434$ (23); 456 (77).

\section{$180 b$}

${ }^{1} \mathrm{H}-\mathrm{NMR}\left(500 \mathrm{MHz}, \mathrm{CDCl}_{3}\right): \delta[\mathrm{ppm}]=1,25\left(\mathrm{~s}, 3 \mathrm{H}, 18-\mathrm{H}_{3}\right) ; 1,98\left(\mathrm{~s}, 3 \mathrm{H}, \mathrm{Ac}_{-} \mathrm{CH}_{3}\right) ; 2,80(\mathrm{~m}$, $\left.2 \mathrm{H}, 6-\mathrm{H}_{2}\right) ; 3,55$ (s, 1H, 16-H); 3,81 (s, 1H, 17a-H); 5,02 (s, 2H, $\left.\mathrm{OCH}_{2}\right) ; 6,67(\mathrm{~d}, 1 \mathrm{H}, J=2,2$ $\mathrm{Hz}, 4-\mathrm{H}) ; 6,78$ (dd, $1 \mathrm{H}, J=8,6 \mathrm{~Hz}, J=2,2 \mathrm{~Hz}, 2-\mathrm{H}) ; 7,09$ (d, 1H, $J=8,6 \mathrm{~Hz}, 1-\mathrm{H}) ; 7,32$ (t, $1 \mathrm{H}, J=7,1 \mathrm{~Hz}, 4$ '-H); 7,37 (t, 2H, $J=7,1 \mathrm{~Hz}, 3$ '-H és 5'-H); 7,39 (d, 2H, $J=7,1 \mathrm{~Hz}, 2$ '-H és $\left.6^{\prime}-\mathrm{H}\right) .{ }^{13} \mathrm{C}-\mathrm{NMR} \delta$ [ppm] = 21,1 $\left(\mathrm{Ac}^{\mathrm{A}} \mathrm{CH}_{3}\right) ; 25,1 ; 26,1 ; 26,8 ; 27,6\left(18-\mathrm{CH}_{3}\right) ; 30,3 ; 30,6 ; 35,3$; 38,9; 39,0; 39,1 (C-13); 44,6; 45,5 (C-16); 69,9 $\left(\mathrm{OCH}_{2}\right) ; 81,1(\mathrm{C}-17 \mathrm{a}) ; 112,7$ (C-2); 114,3 (C4); 127,1 (C-1); 127,4 (2C: C-2' és C-6'); 127,8 (C-4'); 128,5 (2C: C-3' és C-5'); 134,8 (C$10) ; 137,3$ (C-1'); 137,4 (C-5); 156,6 (C-3); 159,3 (NCO). MS m/z (\%): $416\left(100,[\mathrm{M}+\mathrm{H}]^{+}\right)$; 417 (30).

\section{1a}

${ }^{1} \mathrm{H}-\mathrm{NMR}(500 \mathrm{MHz}, \mathrm{DMSO}): \delta[\mathrm{ppm}]=0,91\left(\mathrm{~s}, 3 \mathrm{H}, 18-\mathrm{H}_{3}\right) ; 2,74\left(\mathrm{~m}, 2 \mathrm{H}, 6-\mathrm{H}_{2}\right) ; 3,72(\mathrm{~m}$, $1 \mathrm{H}, 16-\mathrm{H}) ; 3,81(\mathrm{~m}, 1 \mathrm{H}, 17 \mathrm{a}-\mathrm{H}) ; 4,00\left(\mathrm{~s}, 2 \mathrm{H}, \mathrm{CH}_{2} \mathrm{Cl}\right) ; 4,43$ (d, 1H, J= 5,0 Hz, OH); 5,04 (s, $\left.2 \mathrm{H}, \mathrm{OCH}_{2}\right) ; 6,71(\mathrm{~d}, 1 \mathrm{H}, J=2,2 \mathrm{~Hz}, 4-\mathrm{H}) ; 6,76(\mathrm{dd}, 1 \mathrm{H}, J=8,6 \mathrm{~Hz}, J=2,2 \mathrm{~Hz}, 2-\mathrm{H}) ; 7,18$ (d, $1 \mathrm{H}, J=8,6 \mathrm{~Hz}, 1-\mathrm{H}) ; 7,31$ (t, 1H, $J=7,1 \mathrm{~Hz}, 4$ '-H); 7,38 (t, 2H, $J=7,1 \mathrm{~Hz}, 3$ '-H és 5'-H); $7,42\left(\mathrm{~d}, 2 \mathrm{H}, J=7,1 \mathrm{~Hz}, 2\right.$ '-H és 6 '-H); $8,10(\mathrm{~d}, 1 \mathrm{H}, J=7,5 \mathrm{~Hz}, \mathrm{NH}) .{ }^{13} \mathrm{C}-\mathrm{NMR} \delta$ [ppm] $=$ 22,0 (C-18); 25,8; 26,1; 27,8; 29,5; 34,7; 36,6; 36,9; 37,1; 42,6; $42,7\left(\mathrm{CH}_{2} \mathrm{Cl}\right) ; 43,0 ; 47,1$; 64,9 (C-17a); 68,9 $\left(\mathrm{OCH}_{2}\right) ; 112,3(\mathrm{C}-2) ; 113,9(\mathrm{C}-4) ; 126,2(\mathrm{C}-1) ; 127,4$ (2C: C-2' és C-6'); 127,6 (C-4'); 128,3 (2C: C-3' és C-5'); 132,6 (C-10); 137,3 (C-1'); 137,4 (C-5); 156,0 (C-3); 164,7 (NCO). MS m/z (\%): 450 (100); 452 (37); 490 (20).

\section{$181 b$}

${ }^{1} \mathrm{H}-\mathrm{NMR}(500 \mathrm{MHz}, \mathrm{DMSO}): \delta[\mathrm{ppm}]=1,23\left(\mathrm{~s}, 3 \mathrm{H}, 18-\mathrm{H}_{3}\right) ; 2,71\left(\mathrm{~m}, 2 \mathrm{H}, 6-\mathrm{H}_{2}\right) ; 3,50(\mathrm{~s}, 1 \mathrm{H}$, $16-\mathrm{H}) ; 3,91(\mathrm{~s}, 1 \mathrm{H}, 17 \mathrm{a}-\mathrm{H}) ; 4,01$ és $4,15\left(2 \mathrm{xd}, 2 \mathrm{x} 1 \mathrm{H}, J=11,8 \mathrm{~Hz}, \mathrm{CH}_{2} \mathrm{Cl}\right) ; 5,03(\mathrm{~s}, 2 \mathrm{H}$, $\left.\mathrm{OCH}_{2}\right) ; 6,66(\mathrm{~d}, 1 \mathrm{H}, J=2,2 \mathrm{~Hz}, 4-\mathrm{H}) ; 6,75(\mathrm{dd}, 1 \mathrm{H}, J=8,6 \mathrm{~Hz}, J=2,2 \mathrm{~Hz}, 2-\mathrm{H}) ; 7,06(\mathrm{~d}, 1 \mathrm{H}$, $J=8,6 \mathrm{~Hz}, 1-\mathrm{H}) ; 7,31$ (t, 1H, $\left.J=7,1 \mathrm{~Hz}, 4^{\prime}-\mathrm{H}\right) ; 7,37$ (t, 2H, $J=7,1 \mathrm{~Hz}, 3$ '-H és 5'-H); 7,41 $\left(\mathrm{d}, 2 \mathrm{H}, J=7,1 \mathrm{~Hz}, 2\right.$ '-H és 6 '-H). ${ }^{13} \mathrm{C}-\mathrm{NMR} \delta$ [ppm] $=24,5 ; 25,7 ; 25,9 ; 26,9$ (C-18); 29,8; 30,$0 ; 34,7 ; 38,0 ; 38,3 ; 38,8 ; 43,7\left(\mathrm{CH}_{2} \mathrm{Cl}\right) ; 44,0 ; 45,3 ; 68,9\left(\mathrm{OCH}_{2}\right) ; 80,2(\mathrm{C}-17 \mathrm{a}) ; 112,5(\mathrm{C}-$ 2); 113,9 (C-4); 126,9 (C-1); 127,4 (2C: C-2' és C-6’); 127,5 (C-4'); 128,2 (2C: C-3' és C5'); 134,5 (C-10); 136,8 és 137,3 (C-5); 137,3 (C-1'); 154,9 (C-3); 155,8 (NCO). MS m/z (\%): 450 (100); 452 (37).

\section{1c}

${ }^{1} \mathrm{H}-\mathrm{NMR}\left(500 \mathrm{MHz}, \mathrm{C}_{6} \mathrm{D}_{6}\right): \delta[\mathrm{ppm}]=0,80$ (s, 3H, 18- $\left.\mathrm{H}_{3}\right)$; 2,68 és 2,88 (2xm, 2x1H, 6- $\mathrm{H}_{2}$ ); 3,49 és 3,58 (2xd, 2x1H, $\left.J=11,8 \mathrm{~Hz}, \mathrm{CH}_{2} \mathrm{Cl}\right) ; 3,73(\mathrm{t}, 1 \mathrm{H}, J=7,1 \mathrm{~Hz}, 17 \mathrm{a}-\mathrm{H}) ; 4,1(\mathrm{~s}, 1 \mathrm{H}, 16-$ $\mathrm{H}) ; 4,77\left(\mathrm{~s}, 2 \mathrm{H}, \mathrm{OCH}_{2}\right) ; 6,30(\mathrm{~d}, 1 \mathrm{H}, J=4,7 \mathrm{~Hz}, \mathrm{NH}) ; 6,77(\mathrm{~d}, 1 \mathrm{H}, J=2,2 \mathrm{~Hz}, 4-\mathrm{H}) ; 6,81$ (dd, $1 \mathrm{H}, J=8,6 \mathrm{~Hz}, J=2,2 \mathrm{~Hz}, 2-\mathrm{H}$ ); 7,06-7,30 (átfedő multiplettek, 6H, 1-H, 2'-H, 3'-H, 4'-H, 
$\left.5^{\prime}-\mathrm{H}, 6{ }^{\prime}-\mathrm{H}\right) .{ }^{13} \mathrm{C}-\mathrm{NMR} \delta$ [ppm] $=21,4(\mathrm{C}-18) ; 24,3 ; 26,9 ; 27,4 ; 30,4 ; 34,8 ; 35,6 ; 38,1$ (C-13); 40,9; 42,8; 44,3; 47,1 (C-16); 47,9; 64,3 (C-17a); 70,0 $\left(\mathrm{OCH}_{2}\right) ; 113,3(\mathrm{C}-2) ; 114,8$ (C-4); 127,0 (C-1); 127,6 (2C: C-2' és C-6’); 128,3 (C-4'); 128,7 (2C: C-3' és C-5'); 132,8 (C-10); 137,7 (C-5); 138,0 (C-1'); 157,5 (C-3); 164,2 (NCO). MS m/z (\%): 450 (100); 357 (43); 490 (40).

\section{2a}

${ }^{1} \mathrm{H}-\mathrm{NMR}(500 \mathrm{MHz}, \mathrm{DMSO}): \delta[\mathrm{ppm}]=0,95\left(\mathrm{~s}, 3 \mathrm{H}, 18-\mathrm{H}_{3}\right) ; 2,77\left(\mathrm{~m}, 2 \mathrm{H}, 6-\mathrm{H}_{2}\right) ; 3,85(\mathrm{~m}$, $1 \mathrm{H}, 17 \mathrm{a}-\mathrm{H}) ; 3,98(\mathrm{~m}, 1 \mathrm{H}, 16-\mathrm{H}) ; 4,43(\mathrm{~d}, 1 \mathrm{H}, J=5,0 \mathrm{~Hz}, \mathrm{OH}) ; 5,05\left(\mathrm{~s}, 2 \mathrm{H}, \mathrm{OCH}_{2}\right) ; 6,73$ (d, $1 \mathrm{H}, J=2,2 \mathrm{~Hz}, 4-\mathrm{H}) ; 6,77$ (dd, $1 \mathrm{H}, J=8,6 \mathrm{~Hz}, J=2,2 \mathrm{~Hz}, 2-\mathrm{H}) ; 7,20$ (d, 1H, $J=8,6 \mathrm{~Hz}, 1-$ $\mathrm{H}) ; 7,32$ (t, 1H, $J=7,1 \mathrm{~Hz}, 4$ '-H); 7,38 (t, 2H, $J=7,1 \mathrm{~Hz}, 3$ '-H és 5'-H); 7,42-7,47 (átfedö multiplettek, 4H, 2'-H és 6'-H, 3"'-H és 5"-H); 7,51 (t, 1H, $J=7,1 \mathrm{~Hz}, 4$ "-H ); 7,85 (d, 2H, $J=$ $7,1 \mathrm{~Hz}, 2$ "'-H és 6"-H); 8,22 (d, 1H, $J=7,5 \mathrm{~Hz}, \mathrm{NH}) .{ }^{13} \mathrm{C}-\mathrm{NMR} \delta$ [ppm] = 22,1 (C-18); 25,9; 26,$2 ; 27,9 ; 29,6 ; 34,8 ; 36,7 ; 37,0 ; 37,2 ; 42,7 ; 43,0 ; 47,3 ; 65,1(\mathrm{C}-17 \mathrm{a}) ; 68,9\left(\mathrm{OCH}_{2}\right) ; 112,3$ (C-2); 114,0 (C-4); 126,1 (C-1); 127,1 (2C: C-2" és C-6"); 127,4 (2C: C-2' és C-6'); 127,6 (C-4'); 128,0 (2C: C-3" és C-5"); 128,3 (2C: C-3' és C-5'); 130,9 (C-4"); 132,7 (C-10); 134,6 (C-1”); 137,3 és 137,4 (C-5 és C-1'); 156,0 (C-3); 165,1 (NCO). MS m/z (\%):478 (23, $\left.[\mathrm{M}+\mathrm{H}]^{+}\right) ; 496(100) ; 518(47)$.

\section{$182 b$}

${ }^{1} \mathrm{H}-\mathrm{NMR}(500 \mathrm{MHz}, \mathrm{DMSO}): \delta$ [ppm] = 1,25 (s, 3H, 18- $\left.\mathrm{H}_{3}\right) ; 2,69$ (m, 2H, 6- $\left.\mathrm{H}_{2}\right) ; 3,68$ (s, 1H, $16-\mathrm{H}) ; 4,04$ (s, 1H, 17a-H); 5,01 (s, 2H, $\left.\mathrm{OCH}_{2}\right) ; 6,64$ (s, 1H, 4-H); 6,75 (dd, 1H, J = 8,4 Hz, $J$ $=1,6 \mathrm{~Hz}, 2-\mathrm{H}) ; 7,06(\mathrm{~d}, 1 \mathrm{H}, J=8,6 \mathrm{~Hz}, 1-\mathrm{H}) ; 7,30\left(\mathrm{t}, 1 \mathrm{H}, J=7,1 \mathrm{~Hz}, 4{ }^{\prime}-\mathrm{H}\right) ; 7,35-7,47$ (átfedő multiplettek, 7H, 2"-H, 3'-H, 3"'-H, 4"-H, 5'-H, 5"-H, 6"-H); 7,88 (d, 2H, J = 7,8 Hz, $2^{\prime}$-H és 6 '-H). ${ }^{13} \mathrm{C}-\mathrm{NMR} \delta$ [ppm] $=25,0 ; 25,9 ; 26,0 ; 27,3(\mathrm{C}-18) ; 29,6 ; 30,0 ; 34,7 ; 38,5$ (C13); 38,9; 39,0; 43,9 (C-16); 45,4; 68,9 $\left(\mathrm{OCH}_{2}\right)$; 80,0 (C-17a); 112,6 (C-2); 113,9 (C-4); 126,5 (2C: C-2' és C-6'); 127,0 (C-1); 127,4 (2C: C-2" és C-6”); 127,5 (C-4”); 128,0 (2C: C3' és C-5'); 128,2 (2C: C-3" és C-5”); 130,2 (C-4'); 133,4 (C-1'); 134,4 (C-10); 136,8 (C-5); 137,3 (C-1"); 153,9 (C-3); 155,8 (NCO). MS m/z (\%): $478\left(100,[\mathrm{M}+\mathrm{H}]^{+}\right) ; 479$ (30).

\section{4}

${ }^{1} \mathrm{H}-\mathrm{NMR}\left(500 \mathrm{MHz}, \mathrm{CDCl}_{3}\right): \delta$ [ppm] = 1,07 (s, 3H, 18- $\mathrm{H}_{3}$ ); 1,94 és 2,03 (2xs, 2x3H, 2xAc$\left.\mathrm{CH}_{3}\right) ; 2,87\left(\mathrm{~m}, 2 \mathrm{H}, 6-\mathrm{H}_{2}\right) ; 4.00(\mathrm{~m}, 1 \mathrm{H}, 16-\mathrm{H}) ; 5,03\left(\mathrm{~s}, 2 \mathrm{H}, \mathrm{OCH}_{2}\right) ; 5,31(\mathrm{dd}, 1 \mathrm{H}, J=11,5 \mathrm{~Hz}$, $J=4,4 \mathrm{~Hz}, 17 \mathrm{a}-\mathrm{H}) ; 5,36(\mathrm{~d}, 1 \mathrm{H}, J=7,2 \mathrm{~Hz}, \mathrm{NH}) ; 6,71(\mathrm{~d}, 1 \mathrm{H}, J=2,2 \mathrm{~Hz}, 4-\mathrm{H}) ; 6,75(\mathrm{dd}, 1 \mathrm{H}$, $J=8,6 \mathrm{~Hz}, J=2,2 \mathrm{~Hz}, 2-\mathrm{H}) ; 7,16(\mathrm{~d}, 1 \mathrm{H}, J=8,6 \mathrm{~Hz}, 1-\mathrm{H}) ; 7,30$ (t, 1H, $\left.J=7,1 \mathrm{~Hz}, 4^{\prime}-\mathrm{H}\right)$; $7,35\left(\mathrm{t}, 2 \mathrm{H}, J=7,1 \mathrm{~Hz}, 3\right.$ '-H és 5 '-H), 7,42 (d, 2H, $J=7,1 \mathrm{~Hz}, 2$ '-H és 6 '-H). ${ }^{13} \mathrm{C}-\mathrm{NMR} \delta$ [ppm] $=21,0 ; 22,8 ; 23,4 ; 26,1 ; 26,6 ; 28,6 ; 29,7 ; 30,0 ; 33,9 ; 35,4 ; 36,5$ (C-13); 37,5; 43,1; 43,2; 47,9; 69,5 (C-17a); 69,9 $\left(\mathrm{OCH}_{2}\right) ; 112,5$ (C-2); 114,3 (C-4); 126,4 (C-1); 127,4 (2C: C-2' és C-6'); 127,7 (C-4'); 128,5 (2C: C-3' és C-5'); 132,6 (C-10); 137,3 (C-1'); 137,9 (C-5); 156,7 (C-3); 169,1 (NCO); 170,2 (AcCO). 